\title{
DEVELOPMENT TRENDS OF SCHOLARLY KNOWLEDGE IN PHILOSOPHY, SOCIOLOGY AND POLITICAL SCIENCES
}

Collective monograph

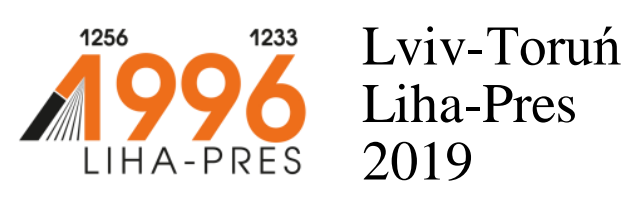




\section{Reviewers:}

Prof. nadzw., dr hab. Stanistaw Kunikowski, Rektor of Cuiavian University in Wloclawek (Republic of Poland);

Prof. $d r$ hab. Kazimierz Pierzchata, Katolicki Uniwersytet Lubelski/Catholic University of Lublin (Republic of Poland);

Prof. dr hab. Stanisław Juszczyk, Uniwersytet Ślaski / University of Silesia (Republic of Poland).

Development trends of scholarly knowledge in philosophy, sociology and political sciences : collective monograph / O. A. Dolzhenkov, L. M. Dunayeva, N. P. Hedikova, L. M. Khyzhniak, etc. - Lviv-Toruń : LihaPres, 2019. $-280 \mathrm{p}$.

ISBN 978-966-397-125-4

Liha-Pres is an international publishing house which belongs to the category "C" according to the classification of Research School for Socio-Economic and Natural Sciences of the Environment (SENSE) [isn: 3943, 1705, 1704, 1703, 1702, 1701; prefixMetCode: 978966397]. Official website - www.sense.nl. 


\section{CONTENTS}

MANAGEMENT IN EDUCATIONAL SECTOR OF UKRAINE

Dolzhenkov O. A 1

THEORETICAL AND METHODOLOGICAL ISSUES

OF THE RESEARCH OF MODERN TRANSFORMATIONAL PROCESSES OF UKRAINIAN SOCIETY

Dunayeva L. M. 23

DYNAMICS OF SOCIO-POLITICAL DEVELOPMENT

OF MODERN UKRAINE IN THE CONTEXT

OF PRIORITIES OF LIBERAL DEMOCRACY

Hedikova N. P.

OPPORTUNITIES OF E-LEARNING AT UNIVERSITIES

IN UKRAINE IN THE OPINION OF TEACHERS

(ACCORDING TO EMPIRICAL SOCIOLOGICAL RESEARCH)

Khyzhniak L. M.

THE KNOWLEDGE ECONOMY AS A PARADIGM

OF THE ESTABLISHMENT AND DEVELOPMENT

OF POST-INDUSTRIAL SOCIETY

Matiuk T. V.

CORRUPTION CONCEPT AND ADVANCED

ANTI-CORRUPTION SYSTEM IN UKRAINE

Muzychenko G. V.

DEFINITION OF LOCAL SELF-GOVERNMENT

IN THE CONTEXT OF LOCAL DEMOCRACY

DEVELOPMENT IN UKRAINE

Naumkina S. M.

NEW HOMO ECONOMICUS:

CONTEMPORARY CONTEXT

Petinova O. B. 132 
GLOBALIZATION - A CHALLENGE

FOR MODERN EDUCATION

Poluiaktova O. V. 151

FUNDAMENTALS OF THE THEORY

OF INFORMATION WAR

Pronoza I. I. 168

FEATURES OF REGIONAL IDENTITY FORMATION

IN THE UK AND ITALY: COMPARATIVE ANALYSIS

Rostetska S. I. 187

SOCIAL ENVIRONMENT OF HIGHER

EDUCATION ESTABLISHMENT AS A SYSTEM-FORMING

FACTOR OF PROFESSIONAL SOCIALISATION

Shaposhnykova I. V. 205

UKRAINE IN THE CONTEMPORARY GEOPOLITICAL SPACE: TRENDS, RISKS AND THE CRISIS OF CHOICE

Shchedrova H. P. 223

"LEFT-RIGHT" PARTY-IDEOLOGICAL DELINEATION

AS A PRINCIPAL MEAN OF STRUCTURING

OF THE POLITICAL LANDSCAPE

Shypunov H. V., Prokop M. .246 


\section{MANAGEMENT IN EDUCATIONAL SECTOR OF UKRAINE}

\section{Dolzhenkov O. A.}

\section{INTRODUCTION}

Management in educational sector has its own specifics and regularities that are inherent only to it. In Ukraine, the study of the problems of managerial activity in education (emphasis on psychological problems) began in the early 70's of the twentieth century. It mainly aimed at: studying the psychological prerequisites for optimizing the leadership of the pedagogical staff of the school and creating a favorable, creative socio-psychological and business climate in it; the influence of the personal qualities of the school principal (director), his style of leadership on cohesiveness and professional capacity of the teaching staff; the quality of the educational process; psychological competence of managers and forms and methods for raising its level; motivation of directors of general educational institutions (secondary schools) to increase the level of management activity, etc. (G. Yelnikova,
L. Kalinina,
L. Karamushka,
N. Kolominskii,
S. Moskvichov,

G. Polyakova, S. Sysoev, R. Shakurov and others).

The efforts of many well-known scholars are directed at the study of education management problems: E. Berezniak (features of management of a modern school), V. Bondar (didactic aspects of the managerial activity of the school principal), L.Vaschenko (system of management of innovative processes in the general secondary education of the region), L. Danilenko (socio-pedagogical aspect of the efficiency of management of the general school), O. Elbrecht (adaptive management of the educational process of a secondary school), Y. Konarzhevsky (pedagogical analysis of school management), O. Marmaza (management in education), V. Maslov (theoretical foundations of pedagogical management), L. Orban-Lembrik (acmeological aspects of professional management), V. Pikel'naya (school management and modeling of managerial activities), V. Sukhomlinsky (peculiarities of the professional activity of the school principal), E. Hrykova (management of an educational institution), T. Shamova (management of educational systems 
in an adaptive school), and others. Most of their works relate to the system of general secondary and postgraduate education.

Currently, there are quite a few publications devoted to the professionalism and professional competence of the manager of a comprehensive educational institution, and ways of improving and improving the effectiveness of his management activities are offered.

The dynamics of development of educational sphere throughout last years shows some drastic alternations that take place. The sphere of management of educational institutions is characterized by a saturation with human resources, that often results in contradiction of interests between separate persons, as well as large and small groups. For quick and, at the same time, effective resolution of such problems a manager should posess theoretical knowledge and practical skills in the sphere of a complex decision of business conflicts. From the scientific point of view the problem of starting and development of business conflicts was researched by such scientists as: V. Andrianov, A. Bandurina, B. White, A. Dmitrieva, V. Druzhinina, Y. Zaprudskiy, A. Kitov, H. Kornelius, N. Kroshus, V. Kudryavtseva, K. Levin, G. Lozhkin, D. Mayers, J. Piapoe, O. Sannikova, V. Semichenko, J. Scott, S. Fayre and others.

Actuality of this issue is predefined by the fact that researches of business conflicts in the sphere of the management of educational institutions up to this time has had mainly situative character. According to this, research of theoretical aspects connected with the features of managing business conflicts is a necessity.

\section{Management and administration in general education of Ukraine}

Manager of an educational institution is a person who professionally manages the organizational system and the staff of an educational institution within the framework of his duties at different levels of management. The modern manager of the educational institution not only honestly performs his professional duties. He is aimed at the future in his professional activities. His professional (managerial) activity is in its essence acmeological.

The acmeologic activity of the manager is the activity aimed on the improvement and development of his own acmeological abilities and managerial skills in order to increase the effectiveness of management of the organizational system. Managerial activity is a purposeful, selforganized social-psychological system, the unity of interconnected 
structural and functional components that are associated with solving managerial tasks to achieve the main goals of the organization.

The most significant features of managerial activity are:

1. Supporting in optimal operating mode the control systems that are complex in their elements and heterogeneous in function of objects (target). Effective functioning of management systems is based on: planning, control, correction, adaptation, emotional identification, consolidation.

2. The object of managerial activity is an organization whose hierarchical structure can be one-component and multi-component.

3. There is a constant functional relationship between professional positions, which determines the relationship between people who appear to be the bearers of these positions.

4. Direction for optimization of managerial activity with the help of economic, administrative, psychological, psychotherapeutic and pedagogical influences.

5. Reception, processing information and generating new information in the form of managerial decision.

6. As the main way of presenting information in managerial activities, indicators and means for describing the characteristics of an object of management, functional and causal relationships between its elements, between the object of management and the environment are used.

7. Relating the generated information to other people.

8. Direct involvement of the subject of managerial activities in the performance of his own solution to professional problems ${ }^{1}$.

The main tasks of managerial activity are the following:

- definition of the main goal and objectives tree, formation and corresponding formulation of the strategy of action for achievement of the general goal, formulation of the concept of development and activity of the corresponding organization (educational institution);

- staffing around the general organizational purpose;

- social and professional motivation of personnel for the purposes of the organization and solving problems that arise once or twice depending on the situation;

${ }^{1}$ Деркач А.А. Акмеологические основы управленческой деятельности. Москва, 2000. Т. 2. $536 \mathrm{c}$. 
- formation, maintenance and correction (if necessary) of organizational order in an educational institution, the requirements of which are documented;

- development and implementation of the latest management technologies;

- diagnostics of control for determining the points of maximum and minimum controllability;

- the formulation of managerial decisions and a clear idea of the ways and the course of their implementation;

- implementation of managerial decisions and regulation of this process;

- development and implementation of control system for the implementation of managerial decisions.

Considering the manager of education as a subject of management activity, N. Kolominsky identified groups of abilities that are necessary for the successful management of their functions ${ }^{2}$ : diagnostic, predictive, design, organizational, communicative, comparative-assessment, academic, emotional-volitional. Also, the scientist highlights such professionalimportant qualities of managers-professionals of educational institutions: analytical-synthetic ability (diagnostic ability); imagination abilities, anticipation (prognostic and design abilities); altruism, empathy, reflection (organizational and communicative abilities); criticality of mind, predisposition to comparison (comparative-assessment abilities); flexibility and depth of thinking (gnostic abilities); social vigor, internality, endurance (emotional and volitional abilities). It is the presence of a unique ensemble of such qualities that allows the head of a general educational institution to skillfully perform his or her professional functions.

Professionally important qualities of a manager of the educational institution determine the style of his management. There are three main classical individual styles: authoritarian, democratic and liberal.

The authoritarian leadership style is characterized by the maximum centralization of the power of the leader in his hands. This style corresponds to the subject-object (technocratic) model of the interaction of the manager with subordinates whose essence is the absolute lack of interest to the employee as to personality. Democratic (collegial) style of

2 Коломонський Н.Л. Психологія менеджменту в освіті (соціальнопсихологічний аспект) : автореф. дис. ... д. псих. наук : 19.00.05. Київ, 2001. 37 с. 
management corresponds to the subject-subjective (human) model of interaction. The liberal-anarchist style of leadership corresponds to the object-subjective model of the interaction of the manager with subordinates.

In addition to these three main styles, one can distinguish the liberalpermissive (participative) style of leadership, which has the following features: regular meetings of the head with subordinates, openness in relations between the leader and subordinates, the delegation of a number of powers, rights, etc to the subordinates. The role of a manager is reduced to the functions of a consultant, coordinator, organizer, supplier.

Participative style is used, if the manager is confident, has a high educational and creative level, is able to appreciate and use the creative proposals of the subordinates; subordinates have a high level of knowledge, skills, need for creativity, independence, personal growth, interest in work ${ }^{3}$. The model of the interaction of the manager with subordinates is also object-subjective.

The style of the head of the educational institution naturally forms the style of work of the staff of the institution headed by him (a separate structural unit of the institution). Therefore, it is important to develop democratic principles at all levels of the managerial process at an educational institution.

By critically analyzing the factors of productivity of professional activity, the scientists - acmeologists N. Kuzmina, S. Pozharsky and L. Pautova believe that the acmeological factors ignificantly influence the managerial activity: increasing the productivity of such activity (enthusiasm for it), increasing the quality of joint activity of the employees (professional-personal self-development), increasing the productivity of creative activity (self-realization of creative potential in the activity) ${ }^{4}$.

The specificity of managerial activity is also determined by the external and internal conditions in its course. Among the external conditions should be distinguished: clearly defined time constraints,

3 Тищенко О.І. Феномен керівництва та лідерства в системі управлінської діяльності. URL: http://www.nbuv.gov.ua/portal/soc_gum/pfto/2010_9/ files/pd910_31.pd (дата звернення: 01.06.2019)

4 Кузьмина Н.В., Паутова Л.Е., Пожарский С.Д. Акмеология качества профессиональной деятельности специалиста : монография. Санкт-Петербург, 2008. $376 \mathrm{c}$. 
constant informational uncertainty, high responsibility for final results and subordinates, unregulated labor, lack of material, financial, information resources, work in extreme and stressful situations, etc. The internal conditions include: simultaneous solving of many tasks, controversy and often uncertainty of regulation requirements, lack of clearly formulated criteria for assessing the effectiveness of activities, diverse subordination of the head to various higher authorities, etc.

The effectiveness of the managerial system is determined by the follows: competence, perspective, completeness and clarity of setting general and specific goals, as well as specifying the tasks of development of a managed level; formation of subordinate joint production interests, goals and actions for the implementation of the tasks set; clarity of organization of the headed collective; completeness and prospects of planning and high level of implementation of the plan, control and adjustment; high professional competence, organization, democracy, tolerance, responsibility for the state of affairs, perseverance ${ }^{5}$.

According to N. Kolominsky, the essence of educational management is the conscious interaction of the manager with subordinates, partners, their leaders, pupils, parents, representatives of the public, which is aimed at achieving the stated goal. The object of management in education is the process of management of educational institutions. Its effectiveness depends directly on the quality of managerial activity of the manager of a comprehensive institution.

Viewing the peculiarities of managerial activity in the conditions of reforming the modern education of Ukraine, as well as the characteristic features of the current state of the system of education management and ways of its further modernization, it is worth to mention that the success of the manager is determined by the presence of such qualities: a broad outlook, a sense of the situation, a creative attitude to work, readiness for change, professional mobility, the desire for cooperation, self-motivation and motivation of personnel to achieve productive results, the ability to predict the results of professional activity (anticipation), ability to take risks, positive attitude not only to work and employees, but also to oneself, logical thinking, ability to act independently, ability to take

${ }^{5}$ Педагогіка : модульний курс / І.П. Анєнкова та ін. Львів : Новий Світ, 2010. $567 \mathrm{c}$ 
responsibility for himself, etc. The presence of such a set of qualities determines the ideal model of the manager.

Of course, practice shows that such an ideal is unattainable, but it makes sense to form such an ideal to identify the possibilities for their achievement. And this can be helped by the knowledge and practical consideration of the acme-synergetic grounds for the development of the personality of the professional manager, especially in such an important field as education. Practical formation and development of these qualities are based on the works of F. Genov (peculiarities of the work of managers with the definition of the specifics of the lower and middle levels of management), K. Muzdibayeva (theoretical analysis of responsibility as a psychic phenomenon), M. Savchina (psychology of responsible behavior) etc.

Considering the issue of effective managerial work, we could outline and stress three groups of qualities that must be strictly inherent to the manager as a leader, manager, and organizer: personal (honesty, modesty and justice in respect to others, good physical and mental health, emotional maturity, positive attitude to life and professional work), professional (general and managerial competence; general, technical, economic, legal, informational, psychological, pedagogical culture, high education and creativity, the ability to mobilize in case of emergency, predictability), organizational and business (purposefulness, business activity, discipline and high self-control, high efficiency, communication skills, contact, realism and charisma, tolerance to the weaknesses of subordinates, ability to manage, organize and support the work of the team, be ready for action, risk).

Summing up the analyzed material on the essence of the professional (managerial) activity of the head of a general educational institution, it should be noted that, with all the diversity of its officials, all of them are united by the fact that each function carried out is transformed through its own understanding and attitude towards oneself and others (subordinates, employees, students). Management is a complex multifaceted process of interrelated functions. The structure of management does not remain unchanged, it is characterized by mobility (mobility and changeability).

V. Maslov identifies such functions of management in education as: socio-political, cultural-educational, managerial educational, management of the teaching process, administrative, economic and financial, and 
teaching ${ }^{6}$. V. Zvereva emphasizes the following components in the activities of the school's director: organizational-pedagogical, educational, publicorganizational, instructional, methodical, administrative and administrative, financial and economic. In addition, she defines organizational and pedagogical activity as a cyclical one, which is implemented through four stages -1 ) the choice and formulation of the purpose of activity, the choice of means for its implementation; 2) the selection and training of performers, 3) the definition of organizational relationships between them, 4) the evaluation of the results of activities ${ }^{7}$. Others offer very similar list of managerial functions which usually includes: planning, organization, regulation, adjustment, accounting and control, pedagogical analysis, stimulation.

Functions of management - these are activities that are clearly segregated both on the basis of the time of their implementation, and on managerial tasks. Such functions are related to the tasks of the development of an educational institution, and the functions of the manager are connected both with the tasks of development, and with the current tasks. Managerial functions are fundamental, unchanged types of managerial activities that reflect the overall logic of management. The functions of the manager of the educational institution are related to the current situation, the peculiarities of the educational institution, the peculiarities of the educational paradigm, and they are more variable.

\section{Management of business conflicts in an educational institution}

During the last years the sufficient amount of interesting and important researches is conducted in relation to the problems of business conflicts. There is a prooved increase of interest for the study of problem of conflict, however as yet a systematic research in separate directions is insufficient.

Before examining the features of business conflicts in educational institutions, it worth to mention that there are plenty of theories and wide range of approaches to concepts of "conflict" and "business conflict".

For the first time concept of "conflict" as multilevel social phenomenon was studied by Adam Smith in his famous work "Research about nature and

6 Маслов В.І. Наукові основи та функції управління загальноосвітніми навчальними закладами. Тернопіль : Астон, 2007. 150 с.

${ }^{7}$ Маслов В.І. Принципи менеджменту в установах освіти. Освіта і управління. 1997. Вип. 1. С. 77-84. 
reasons of riches of nations". A. Smith examined conflicts between opposing social classes as a source of development of society ${ }^{8}$.

Later W. Fisher determined a conflict a state of shock and disorganization in comparison with previous development that is the generator of new structures ${ }^{9}$.

Founder of independent direction in the study of conflicts in American sociology and conflictology W. Lincoln considered conflict from the position of pragmatism. In his opinion, a conflict is understanding, imagination or realizing by any single side the fact that other side or sides ignore or violate its interests ${ }^{10}$.

A. Antsupov determines a conflict through the selection of the stages of conflict: the base-line state, pre-conflict state, conflict state, transitional state, state of fixing of result of conflict ${ }^{11}$.

O. Kravchenko characterizes a conflict as situation in which the oppositely directed forces of approximately equal size influence on an individual simultaneously ${ }^{12}$.

D. Zelke worked out the theory of social conflict, according to which, a conflict is a fight around the values and solicitations caused by the deficit of status, power and tools, in which aims of opponents are being neutralized by their rivals ${ }^{13}$.

Thus, a conflict is the very difficult social and psychological phenomenon, successful study of which greatly depends on quality of methodological and theoretical pre-conditions and methods that is used.

Provided the general description of conflict, it seems necessary to precise such concepts as a "social conflict", "business conflict", "conflict situation".

In the sociological dictionary of Y.Babosov the completest determination of social conflict is given: a social conflict is a case of maximum intensication of social contradictions, that is expressed in the conflict of interests of different social associations, - classes, nations,

\footnotetext{
$205 \mathrm{c}$.

${ }^{9}$ Фишер Р. Путь к согласию. Москва, 1990. 312 с.

${ }_{11}^{10}$ Линкольн У. Переговоры. Рига, 1998. 189 с.

${ }_{11}^{11}$ Анцупов А.І., Шипілов А.І. Конфліктологія. Москва : ЮНІТІ, 2000. 551 с.

12 Кравченко О.П. Погляд конфліктолога на онтосинтез конфлікту. Соціологічні дослідження. 2004. Вип. 9. С. 103-112.

13 Зельке Д.С., Віллерман М. Конфлікти та їх розв'язання у початковій школі. Суми, 1992. 164 с.
}

${ }^{8}$ Сміт А. Дослідження про природу і причини багатства народів. Москва, 1993. 
states, different social groups, and institutes, caused by opposition or difference of their interests, aims, progress trends" ${ }^{14}$.

Analysing scientific works related to origin and features of conflict situations, it could be generalized, that a conflict situation is interaction of the conflicting parties caused by an incident or occasion. A conflict situation is begun with an occasion. At the same time, an occasion is external, well realized reason of conflict. An occasion comes out in the form of claims.

N. Grishina points out that business conflict has a subject-object contradiction is the basis. Contradictions can exist for the long period and not to come out in a conflict. It is therefore necessary to consider that only incompatible contradictions, based on interests, necessities and values, could lie in basis conflict. Such contradictions, as a rule, are transformed in the open fight of parties, in the real opposing. Thus, a business conflict is the conflict based on contradictions directly in the sphere of professional activity ${ }^{15}$.

Therefore, a business conflict, as well as social, is unfolded and resolved in a certain situation connected with the origin of problem that requires a decision; both types of conflict have certain reasons, transmitters, own certain functions, duration and level of sharpness. However unlike social, a business conflict arises up only in the case when professional interests are at stake. At the same time, a conflict situation is only the fragment of conflict, episode of its development. However, sometimes the structure of conflict can be examined according to the structure of conflict situation.

Taking into account the above-mentioned, it is necessary to determine the structure of business conflict. With reference to scientific views of A. Dontsova, a structure of business conflict is the following:

1. Basic participants of conflict are those subjects of conflict, that directly act against each other. Opposite parties are a key link of conflict. When one of parties goes out of a conflict, then it ceases. It is also possible to mark a side that began a conflict - initiator, but in the protracted conflicts, doing it is more difficult. In a business conflict one distinguish important description of opponent - level. It is a level of possibilities of opponent from realization of the aims in a conflict, that is

\footnotetext{
${ }^{14}$ Бабосов Е.М. Энциклопедический словарь. Москва : Книжный дом, 2009. 480 с.

${ }^{15}$ Гришина Г.Б. Психология конфликта. Москва, 2002. 464 с.
} 
expressed in influentialness of his structure and connections, skill and ability, its social experience of conflict interaction.

2. Groups of support. Such participants, that is present in any conflict and can be represented by friends, colleagues and others like that.

3. Other participants of conflict are subjects that influence on course and results of conflict. Instigators and organizers could be mentioned here. Sometimes participants of conflict include mediators. The basic task of such third party is stopping the conflict.

4. The reason of conflict is existing problem that serves as basis of conflict, a reason for different parties for contradiction and entering into opposition.

5. The object of conflict can be a material, social or spiritual value, to possession or use of which both opponents aimed.

6. Micro- and macroenvironment of conflict are circumstances in which the participants of conflict operate. Taking into account surroundings of participants of conflict at micro- and macroenvironment level allows to understand their real aims, reasons of parties, and also their dependence on this environment ${ }^{16}$.

Furthermore, a structure of conflict is totality of its features that provide integrity, equality to the itself, difference from other phenomena of social life. Without the presence of these features a conflict can not exist as dinamically interdependent system and process.

In his turn, A. Drunie marks that an important aspect in a managing business conflicts resolution is their dynamics. It is necessary to point out that beginning of conflict can be fixed as the first acts of counteraction of parties. For starting of conflict three obligatory conditions taken together are needed: the first participant consciously acts against the second participant; the second participant realizes that that actions are directed against his interests; therefore he begins corresponding actions against the first participant. However, if the first side began aggressive actions, and second - remain in passive position, then a conflict will not take place ${ }^{17}$.

Analysing scientific work of D. Johnson, it is possible to distinguish the following periods and stages in the dynamics of business conflict :

16 Донцов А.И. Психология коллектива. Москва : Международный гуманитарный университет, 1994. 340 с.

17 Друньє А. Розв'язання конфліктів. Основні принципи успішного керівництва. Москва, 1999. 376 с. 
I. The Latent (pre-conflict) period includes such stages:

1. Origin of objective problem situation. Essence of such situation is in the origin of contradiction between subjects (by their aims, reasons, aspirations and other like that). Such situation is a problem in interaction but that contradiction is not yet realized and conflict actions are absent. A feature is that most problem situations exist for a long time, not coming out.

2. Realization of objective problem situation by the subjects of interaction. Essence of this stage is in that the subjects of conflict understand the necessity of resolution of contradiction. Subjective perception of problem situation is an obstacle for realization of interests by both parties of conflict. Mostly, exact social divergences of participants are the basis of subjectivity of perception of situation. To this category belong values, ideals and interests. On complication of situation speed of development and probability of distortion of events depend by opponents.

3. Attempts of parties to resolve an objective problem situation using unconflict methods. Contradiction of conflict situation is not precondition of conflict interaction of parties. Sometimes the subjects of conflict try to apply unconflict methods: persuasion, elucidation, request, informing. On this stage an argumentation takes place, expressing own interests and fixing of the position.

4. The origin of pre-conflict situation is characterized as a presence of threat for one of parties of conflict. The actions of opponent must be regarded as an instant danger, that assist to development of situation toward a conflict.

II. An open period (period of conflict interaction) or actually conflict includes the next stages:

1. An incident is the first collision of parties.

2. Escalation of conflict. This stage is characterized by sharp intensification of struggle between opponents.

3. Balanced interaction. On this stage activity of parties to resolve the conflict conflict becomes less intensive. Parties see unefficiency of power methods for the achievement of consent.

4. Completion of conflict. The basic difference of this stage from other consists in a transition from conflict interaction to stopping of conflict. Completion of conflict shows up in such forms: decision, settlement, fading, removal, outgrowing in other conflict. 
III. Postconflict period. This period consists of two stages: partial and complete normalization of relations between opponents ${ }^{18}$.

Above-mentioned periods and stages, that characterize the dynamics of business conflict help to understand that as well as other types of conflicts, a business conflict means the collision of sides. However a main difference is that opposition and cooperation of certain target group are taking place. The dynamics of business conflict in educational institutions represent the realized contradiction between the members of corresponding collective, that aspires to the emotional decision in a situation that was folded in interorganizational space.

It should be noticed that a business conflict is a conflict between subjects, that relate to educational institutions, and could be ordinary employee or leaders. Also the participants of business conflict can be separate subdivisions and organizations that connected with the sphere of education.

Therefore unlike other types of conflicts, namely business conflicts in educational institutions are bearing certain features. Firstly, there are differences of the functional systems of educational institutions. In comparing to society educational institutions is more local system. Exactly within the limits of such system there are rules, standards, well-regulated processes that come forward as mechanisms of coordinated behavior. Exactly this feature gives an opportunity for prognostication of conflict situations and reliable application of measures of preventive character. Secondly, important is a role-play structure of educational institutions and its workers. Everybody, in order to achieve certain goal in professional field, pulls out on the first plan professional qualities and inner position. In other words, the role of worker appears in organization, id est set of the expected behavioural stereotypes related to implementation of certain work. Thirdly, for a managing business conflicts in the field of education methods of management of personnel are important. The effective management of educational institutions requires precise application of methods, but development of organizational structure - general system of methods by means of which educational institution conducts distribution of labour process on separate tasks and arrives at co-ordination between these tasks. On the method of implementation of tasks in organization, it worth

18 Джонсон Д.В. Соціальна психологія : тренінг міжособистісного спілкування. Київ : Академія, 2003. 288 с. 
to mention the horizontal and vertical organizational structure of educational institutions. On the basis of horizontal differentiation is conducted the implementation of different tasks in relation to activity of or educational institution after distribution and grouping according to certain principles. The types of horizontal differentiation shows different tasks, for example implementation of work, promotion of educational services, choosing consumers of educational services, at the place of location of educational institution or its separate subdivision. Also educational institutions have vertical distribution. Vertical differentiation is determined by the number of levels of authority, division of administrative specialities. Exactly vertical differentiation influences on satisfaction of stuff of educational institutions.

It is also necessary to mark that managing business conflicts in the field of the management of educational institutions envisages three stages of work with a business conflict: confession of the real reasons of conflict parties / by one side; legitimization of conflict is an achievement of consent between the participants of conflict in relation to confession of the set rules of conflict interaction; institualization of conflict is creation of corresponding bodies in order to adjust conflict interaction ${ }^{19}$.

It is worth to mention that namely the stage of institutialisation is one of basic, in fact on this very stage the mechanism of adjusting of conflict that will be based on clear principles and realized by means of the worked out technologies is being created. Institualisation of conflict for the managers of education can serve as the measure of preventive character. Because such conflicts are predictable, id est it is possible to look after development of that. The process of institutialisation of conflict interaction consists of next stages: structuting of groups (resolving question of accordance of behavior to the transmitters of opposite interests) and reduction of conflict (gradual lowering of conflict by its translation on another level) ${ }^{20}$.

For business conflicts in the sphere of education destructive consequences are inherent, that is why it is necessary for an effective management to be able to diagnose the dynamics of conflict development, work out strategy of actions and provide it by means of

19 Турищева Л.В. Особливості педагогічних конфліктів. Англійська мова в початковій школі. 2006. Вип. 5. С. 6-9.

${ }^{20}$ Ширшов В.Д. Педагогическая коммуникация. Москва, 2001. 240 с. 
certain technological receptions, such as: comprehension of conflict; working out a conflict management; creating a mechanism of inhibition; creation of technologies of managing a conflict.

Analysing the above-mentioned, we underline certain basic principles of managing business conflicts exactly in the sphere of education:

- determination of reasons and pre-conditions of origin of conflict situation;

- strategically shaping an approach to management and resolution of business conflict;

- analysis of existing tools for resolution of conflict and choosing the most effective ones;

- structurisation of subjects of conflict for an objective management and prevention of destructive consequences of the conflict.

For the effective resolution of business conflicts in the sphere of education, it is necessary for the manager or head of an educational institution to apply the extended arsenal of methods of management conflicts. According to tools of conflict resolution we can differ the structural and interpersonal groups of methods. To the structural methods of conflict resolution we can attribute elucidation of requirements to work, using of co-ordinating and integration mechanisms, setting of common aims and use of the system of rewards. Interpersonal methods of conflict resolution in the sphere of educational management are the following: rejection, smoothing, compulsion, compromise, decision of problem ${ }^{21}$.

There are five existing basic styles of conflict resolution, based on the method of Thomas-Killmen. The system allows to work out individual style of conflict resolution. Such possibility exists because basic styles of behavior during a conflict are related to the general source - divergence of interests of two or more parties. Style of behavior of one of parties of conflict will be determined by measures that individual aims to satisfy his own interests and interests of opposite side (parties). The method of Thomas-Killmen envisages the next styles of conflict resolution:

1. Style of competition. Such style is effective only in case when one of the parties of conflict knows that its decision is correct. And in that case it has the opportunity to insist on it.

21 Лапин Г.Г. Социологический анализ организационных систем. Bonpocbl философии. 1974. Вып. 7. С. 38-49. 
7. Style of avoidance is being used in case when for one of the parties of conflict the meaning of a problem is not important and it has no desire to spend resources on its decision.

8. Style of adaptation will be useful if a business result is extraordinarily important for one of the parties of conflict.

9. Style of collaboration one of the hardest because requires a true collaboration. Both sides must be able to expound the necessities, hear each other and only then to lay down the alternative options of problem resolution. Such approach immediately becomes uneffective as soon as there is absent any of these elements ${ }^{22}$.

Analysing different approaches, principles, methods, postulates that are used for the resolution of business conflicts in educational institutions, it is impossible to find the only perfect way of conflict resolution. More promising apptoach is to investigate technologies of managing conflicts.

A successful management of conflict situations in the sphere of education is possible by developing relevant tactics, that will take into account the features of conflict. An important aspect is a search of general tangencies in interests of opponents. In fact this process is bilateral and turns out to be impossible in case of unwillingness (refuses) of opponents. It is important to discuss a problem objectively, finding out the essence of business conflict. In fact the successful search of method of resolution of problem in majoritymostly depends on ability of both sides to see the main and think structurally. For a leader it is important to choose optimal strategy of resolution of conflict situation that meets these circumstances.

For the foresight of development and management of a conflict, it is needed to thoroughly conduct the analytical stage - to investigate the object of conflict, opponents, reasons and direct occasion, that caused a conflict, social environment, secondary reflection. Only after the objective analysis of situation it is necessary to speculate on the options and ways of conflict resolution and to define necessary steps. It is also necessary to understand clearly the development of events as a result of choice of certain strategy and choose the latter according to the most favorable expected result.

22 Поляков А.Б. Конфликтная компетентность руководителя образовательного учреждения. Педагогическая мастерская. 2005. Вып. 4. С. 54-59. 
Giving prognosis on the development of events after the choice of strategy is possible using criteria of resolution of business conflict. Here one could refer to: legal forms, moral principles, opinion of authoritative persons, precedents of decision of analogical problems in the past. Realization of selected strategy takes place according to the select method.

Analysing all abovementioned about the resolution of business conflicts in the sphere of the management of educational institution, it is possible to outline possible tactics of manager of education: resolution of conflict on the basis of its essence; a resolution of conflict on the basis of its aims; resolution of conflict on the basis of its functions; resolution of conflict on the basis of emotionally-cognitive state of participants; resolution of conflict on the basis of properties of its participants; resolution of conflict on the basis of its possible consequences; resolution of conflict on the basis of ethics of relations between rival parties.

Leaning on that research, the system of methodical recommendations was worked out regarding management of business conflicts in educational instiyutions : to do public statements that one of parties of conflict wants to stop escalation of conflict; to conduct elucidation, according to the pre-arranged steps for normalization of relations between parties of conflict; to induce opponents to the exchange acts that will assist the resolution of situation; to conduct preventive events with explanation, that business conflicts are uneffective for all their participants, to specify on reliable consequences; to offer strategies of decision and ways of stopping of business conflicts.

\section{CONCLUSIONS}

Management of a general educational institution is carried out by its director, who is appointed by a public administration body. His duties are clearly defined in the Provision on the general educational institution, which states that the director ensures the implementation of the state educational policy, disposes of school property and funds in the established procedure, approves the budget and its implementation, concludes agreements, opens accounts in banks, manages loans, issues orders binding on all participants in the educational process, organizes and controls the educational process, is responsible for the quality of the work of the teaching staff, the protection of childhood and work, creates 
conditions for extracurricular and extracurricular educational work, appoints and dismisses its deputies and pedagogical workers, approves their official duties and rules of the internal order (together with the trade union committee), creates conditions for the creative growth of teaching staff, is responsible for their activities in front of the team of the school, parents, local authorities.

The main functions of the managerial activity of the director of a general educational institution are the pedagogical analysis of the state of the educational process in the school, the planning of the work, the organization of the school's activities, the intra-school control and the regulation of the life of the school team. The cycle of management of the school begins with the pedagogical analysis of work in the previous period and evaluation of its effectiveness, namely: what gave the activity to managers and teachers; what appeared new in the actions of teachers, life classes, students; how carried out work contributed to the education of students of national consciousness and high moral qualities; what mistakes were made by managers; how optimal was the control. The function of pedagogical analysis provides the basis for planning.

Planning is the main point for management, which means designing the educational process and the process of guidance, defining goals and objectives. Organization of internal school management is the next function - it is putting into action the managerial decision, the implementation of the plan in life. This work consists of choosing the most appropriate forms and methods depending on the timing, arrangement of performers, their business qualities and experience and the provision of guidance.

Control is one of the main means of providing reliable and reliable information about the state of educational work. When conducting the control, it is necessary to observe the relationship and interconnection of forms and time with the content of the educational process, the differentiated approach to objects, the comprehensiveness and depth of coverage of the object of control, systematic and consistent, verification of execution and publicity, the dynamism of forms and methods, involvement in public control.

Today we need a deep study of the educational process, the very essence of interaction between teachers and students, diagnosis of levels of activity of students in teaching, work and communication, and 
provision of timely assistance to the managers of the educational process, making corrections in their activities. And, first of all, the managerial activity in the general educational institution should be aimed at managing not only pupils but also pedagogical personnel, eliminating the causes and consequences of various professional destructions. Democratization in the regulatory process is manifested in the fact that the manager engages teachers and students in collecting and analyzing information about the state of the educational process. Regulation is operative (operational meetings with the director, deputy), thematic (production meetings, pedagogical councils), final (pedagogical council on the results of the academic year, semester, conference). Management functions are organizationally united, the loss of one of the functions negatively affects the management cycle or suspends its execution.

The success of managing a school depends on the position of the director, the style of his work, his competence, and the belief in the need to democratize management. The director-democrat recognizes the need for school councils, tolerates criticism, knows how to conduct a dialogue, does not oppose a team, rely on collective opinion, act deliberately and consistently.

As a result of analysis, we came to the next conclusions: firstly, a concept "business" is investigated enough in socio-humanitarian sciences, also modern scientific literature holds in a spotlight the different aspects of business conflicts. The analysis of approaches to resolution of conflict showed that a business conflict is the conflict based on contradictions directly in the field of professional activity. Furhthermore, a business conflict is being unfolded and resolved in a certain professional situation in touch with the origin of professional problem and has certain reasons, transmitters, owns certain functions, duration and measure of sharpness. The analysis of features of business conflicts in the field of the management of educational institutions gives an opportunity to understand that the difference of business conflicts from other types of conflict is determined by three basic moments : by the differences of the functional systems of educational institution; by the role-play structure of educational institution and by methods of management a personnel.

Taking into account realities of public life, it was certain that a process of management a business conflict is a purposeful influence on 
the dynamics of conflict. An administrative process includes the certain types of activity, such as a prophylaxis and prevention of origin of business conflicts, diagnostics and adjusting of conflict, prognostication of development of conflicts and estimation their functional orientation and possible consequences, process of resolution of conflict. There is plenty of methods and technologies of a managing and resolving business conflicts. It is crucial for leaders in the sphere of education to master on general rules, principles and recommendations for effective application in case conflict situation evolved. Professionalism in making a decision in conflict situations will give possibility to the managers of educational sphere to regulate structurally conflict interaction and to use principles of effective interpersonal business communication.

\section{SUMMARY}

The article is approaching the problem of managing a general educational institution (also known as secondary, or comprehensive school). It presents the analysis of different generalizations connected with the definition of the concepts of «management» and «managerial activity». Disclosing of the peculiarities and specific features of managing an educational institution is being proposed. The analysis of the principles and structure of managerial activity, its planning, role of control and recommendations for improving the management in the general educational institutions are given. The article also analyzes the problem of managing business conflicts in educational institutions. An analysis of scientific views on the definition of the concept of "conflict" and "business conflict" is presented. Specific features of inner conflicts in educational institutions are disclosed. The peculiarities of the structure of business conflicts, the dynamics of their development, and recommendations for improving the management of business conflicts in educational institutions are given.

\section{REFERENCES}

1. Анцупов А.I., Шипілов А.І. Конфліктологія. Москва : ЮHITI, 2000. $551 \mathrm{c}$.

2. Бабосов Е.М. Энциклопедический словарь. Москва : Книжный дом, 2009. 480 с.

3. Гришина Г.Б. Психология конфликта. Москва, 2002. 464 с. 
4. Деркач А.А. Акмеологические основы управленческой деятельности. Москва, 2000. Т. 2. 536 с.

5. Донцов А.И. Психология коллектива. Москва : Международный гуманитарный университет, 1994. 340 с.

6. Друньє А. Розв'язання конфліктів. Основні принципи успішного керівництва. Москва, 1999. 376 с.

7. Джонсон Д.В. Соціальна психологія : тренінг міжособистісного спілкування. Київ : Академія, 2003. 288 с.

8. Зельке Д.С., Віллерман М. Конфлікти та їх розв'язання у початковій школі. Суми, 1992. 164 с.

9. Кравченко О.П. Погляд конфліктолога на онтосинтез конфлікту. Соціологічні дослідження. 2004. Вип. 9. С. 103-112.

10. Коломонський Н.Л. Психологія менеджменту в освіті (соціально-психологічний аспект) : автореф. дис. ... д. псих. наук : 19.00.05. Київ, 2001. 37 с.

11. Кузьмина Н.В., Паутова Л.Е., Пожарский С.Д. Акмеология качества профессиональной деятельности специалиста : монография. Санкт-Петербург, 2008. 376 с.

12. Лапин Г.Г. Социологический анализ организационных систем. Bопросы философии. 1974. Вып. 7. С. 38-49.

13. Линкольн У. Переговоры. Рига, 1998. 189 с.

14. Маслов В.І. Наукові основи та функції управління загальноосвітніми навчальними закладами. Тернопіль : Астон, 2007. 150 с.

15. Маслов B.I. Принципи менеджменту в установах освіти. Освіта і управління. 1997. Вип. 1. С. 77-84.

16. Педагогіка : модульний курс / І.П. Анєнкова та ін. Львів : Новий Світ, 2010. 567 с.

17. Поляков А.Б. Конфликтная компетентность руководителя образовательного учреждения. Педагогическая мастерская. 2005. Вып. 4. С. 54-59.

18. Сміт А. Дослідження про природу i причини багатства народів. Москва, 1993. 205 с.

19. Тищенко О.I. Феномен керівництва та лідерства в системі управлінської діяльності. URL: http://www.nbuv.gov.ua/portal/soc_ gum/pfto/2010_9/files/pd910_31.pd (дата звернення: 01.06.2019)

20. Турищева Л.В. Особливості педагогічних конфліктів. Англійська мова в початковій школі. 2006. Вип. 5. С. 6-9. 
21. Фишер Р. Путь к согласию. Москва, 1990. 312 с.

22. Ширшов В.Д. Педагогическая коммуникация. Москва, 2001. $240 \mathrm{c}$.

Information about the author:

Dolzhenkov O. A.

Doctor of Political Science, Professor,

Head of the Department of Educational Management and Public Administration, South-Ukrainian National Pedagogical University named after K.D. Ushynskiy 26, Staroportofrankivska str., Odesa, 65000, Ukraine 


\section{THEORETICAL AND METHODOLOGICAL ISSUES OF THE RESEARCH OF MODERN TRANSFORMATIONAL PROCESSES OF UKRAINIAN SOCIETY}

\section{Dunayeva L. M.}

\section{INTRODUCTION}

The whole process of transformation of Ukrainian society after independence should be subordinated to the sole goal of building a sovereign and independent, democratic, social, constitutional state and civil society based on market economy and strong social policy. This goal stemmed from the objective needs of the civilized development of our country at the turn of the century. The objective needs of social progress, combined with the goal-aspiration of our people for national independence and well-being, should be transformed into the grand tasks of state building on the basis of democratic principles, transformation of the socialist economy into a market and national revival.

However, modern social development is characterized by crisis phenomena in the functioning of all countries of the world. Globalization processes have led to significant consequences in all spheres of society. Particularly complex processes covered post-socialist countries, that faced with problems of qualitative changes in the system of social institutions and the interconnections between them. The search for a new model of the functioning and development of society for this group of countries is also compounded by the crisis phenomena in social sciences, due to the lack of a clear paradigm, and even more so, a theory that would contain answers to these problems.

Complex and contradictory processes of transformation of modern Ukrainian society cause the need for theoretical and methodological principles, on the basis of which theoretical approaches and concrete social projects of qualitative updating of the system of social institutes of our country are developed. Throughout its history, humanity has created a number of diverse social practices, models of social development, which, in the process of scientific reflection, were presented in relevant scientific theories and paradigms. The task of Ukrainian scientists is to master the world experience of the theory and 
practice of social changes, scientific knowledge about them, and develop an adequate model of social development, which should take into account the historical, political and legal, national-cultural and mental features of contemporary Ukrainian society.

The main thesis of all theoretical studies and methodologies is the impossibility of describing the new social reality characterized by globalization processes, the dissemination of informational technologies and others by means of old methods. The question of the methodology of modern research is a constantly debated topic, since each scientific research must be based on the appropriate methodology of scientific analysis. Modernity testifies not only to the crisis of the search for a paradigm, the crisis of social reality, but about the crisis of science in general.

The present state of the evolution of social science and development of theoretical and methodological foundations have become the subject of research by Western scholars such as I. Wallerstein, D. Bel, Y. A. Toynbee, E. Toffler, S. Huntingon and others. Questions of theoretical and methodological nature were the subject of analysis by such Ukrainian scientists as L. Bevzenko, A. Halchinsky, V. Gorbatenko, G. Pocheptsov, V. Semynozhenko, S. Vovkanych and others.

An analysis of the works of Western scholars became the subject of a special study by A. Galchinsky, who offers to use the theory of complex and non-equilibrium systems as a methodology of new social studies, the author of which is considered by well-known social scientist I. Prigozhin. The methodology of these systems is based on the systematic approach that appears as the basis for this study.

\section{Formation and development of theoretical and methodological approaches to the transformation of modern Ukrainian society}

For modern Ukraine implementation of a model of sustainable and accelerated development requires systemic changes, a set of concrete socio-economic, political, ideological, socio-cultural measures aimed at the formation of qualitatively new, integrated and organic system of society. This set of measures should be based on the study and creative application of historical experience of developed countries of the modern world, which is largely reflected in modern theories of social development. The diversity of these theories has led to the need of systematizing them according to certain criteria within the framework of 
the corresponding paradigms. These criteria are the methodological principles that are inherent in a close group of theories, which is covered by a certain paradigm. It is within the framework of paradigms that Ukrainian researchers carry out an analysis and search for specific theoretical and methodological foundations of a vital model of the development of our society.

Ukrainian researcher S.Vovkanych writes that «for Ukraine, the theory of sustainable development at any level (country or region, nation or individual) will only function effectively when it comprehensively covers the whole range of strategic priorities, including the factors of state formation and nationalization $»{ }^{1}$. Such an approach may be defined as an offer of a paradigmatic approach to the system of social transformations of modern Ukrainian society. The subject of such a paradigm should be not only the classical issues of economic, social and state-legal system, but also the question of the spiritual and intellectual unity of the Ukrainian nation, its consolidation, affirmation and development of political, ethnic, cultural, and religious identity.

However, the success of solving these problems in the conditions of globalization of the modern world depends at a large extent on the introduction of a new socio-humanistic paradigm into the sphere of international relations, the moral and ideological principles of which would be based on the entire complex of factors, which, in addition to the socio-economic and political aspects mentioned, would have taken into account spiritual-intellectual, informational-linguistic, demographic, ethnic and other dimensions, without which social stability and sustainable development are impossible.

In the developed countries of the modern world, there is the so-called integration strategy of development, which tries to fit all of these criteria. It refers to «a set of methods of managing society for targeting its actions, actions in a certain socio-economic, political, environmental areas» ${ }^{2}$ The socio-human component of this management strategy is seen as a paradigmatic binary, the essence of which is the parity approach to harmonizing the combination of rights and protection of both person and nation in the widest range of contexts, as well as in terms of the prompt

${ }^{1}$ Vovkanych S.Y. Socio-humanistic paradigm of integration strategy of Ukraine and its regions. Regional economy. 2008. No. 3. P. 7-22.

Ibid. 
delivery of this moral and legal imperative to international jurisdiction to this socio-humanistic binarism. Such a global interpretation of the format of the strategy involves systemic consideration as the structure of its essential components, and the directions of their functional content and practical implementation. This, in turn, means that the human-nationalstate-centeredness of the community must be determined in the internal dimension, mainly focused on integration around the implementation of the Ukrainian national idea, information space, solution of socioeconomic, national-democratic, administrative-territorial and other problems of the country, in particular, interregional and interindustrial, as well as in the external, international - focused on cooperation or other interactions of Ukrainian society with the world community, with neighbors, in particular their attitude towards the restoration of Ukraine, its spiritual revival and the preservation of the identity of the nation, the choice of the vector and strategic partners on the way to the peaks of world civilization development.

Introduction of such a paradigm in contemporary scientific research raises questions about the relevance of the old methodology of research to new realities, new paradigms. In this regard, more and more scientists in the field of social sciences believe that modern science is in a state of crisis, based on its methodological principles. This is primarily about the need to overcome the principle of "linearity", which expresses the methodological basis of the analysis of social processes. These scholars argue that every historical date, every civilization implies its own model of knowledge, a specific method of studying the connection between theoretical concepts and substantiated conclusions about the real world and its perspectives. It is a fact that during the periods of steep turns in history, theoretical constructions, concepts and laws relating to previous development, their methodological structure, in particular, the method of study, are obsolete and do not correspond to new social realities.

It is necessary to pay close attention to the fundamental warnings concerning the crisis of social sciences. This is said for a long time since the 70's of the last century. This problem became especially acute nowadays when the crisis of science coincided with the crisis of social reality. The modern world undergoes significant changes, and science, being conservative in its essence, does not keep up with these changes. This leads to a significant uncertainty in the social future. 
In general, social sciences do not stand still. A considerable amount of actual material on globalization and national transformations has been worked out. However, it is not a quantitative measure of accumulated knowledge. The crisis in social sciences is the lack of progress in the methodological basis of analysis. The lack of generalizations at the level of the methodology expresses the essence of the problem, which is fully relevant to the latest theoretical generalizations - the theory of postindustrial society. These are the works of D. Bell, O. Toffler, M. Kasteselsva and other scholars, whose works formulate modern scientific ideas about the principles of post-industrialism, which are based on the orthodox methodological principles of traditional modernism. This is their fundamental scientific limitations. They refer to the substantiation of the prerequisites for the approval of the basic principles adequate to the conditions of the transition phase, rather than the basic characteristics of the new post-industrial society, which have not yet fully evaporated.

Thus, in D. Bell's main features of industrial, industrial and postindustrial society are distinguished on the basis of one-line (linear) logic, based mainly on quantitative changes that characterize the sectoral structure of production, distribution of labor, and so on. On the same traditional methodological basis, the specific features of post-industrial society are substantiated by many other scientists. Nowadays, this is an acknowledged fact that determines the fundamental limitations of relevant research. The need for the formation of a new methodological paradigm is primarily due to the fact that the accumulated stratum of scientific concepts of the modern post-industrial era is formed on the old methodological basis of the previous era, on the principles of industrialism, modernist logic.

In the context of the restructuring of the methodology of research on the development of contemporary Ukrainian society, the key issue is to rethink the complex of scientific postulates associated with the concept of causality. This is the problem of the existing frame of causal determinants, which are based on the methodological postulates of Newtonian physics, and in many of its aspects lose their relevance to modern social transformations: to explain the logic of the latter based on the established causal causation clauses becomes impossible.

From the point of view of the logic of global transformations, the most controversial position of this methodology is the absolutization of the principles of technical (technological) and economic determinism, 
according to which technological and economic factors are considered as the driving force of social progress.

Criticism of this doctrine has different aspects. First of all, it takes into account the discrepancy of its frames with real historical processes. In particular, it cannot explain the reasons behind the western technological miracle.

Analyzing the laws of development of civilizations known in the world, we suppose that the degree of domination of society over nature is determined by the level of technical progress, but we observe cases where technical development was accelerated, and civilization remained static.

As an alternative to the aforementioned methodological frame, spiritual values are offered. M. Weber affirmed that the basis of society's development is not technology, not material, but spiritual life, religion, sphere of consciousness as a whole.

Another interpretation of the problem posed is presented by D. Nort, who gives priority to the development of the economy to institutional changes, and first of all to unofficial institutional constraints (customs, traditions, codes of conduct, etc.). "It's impossible to understand history without recognizing the leading role played by subjective preferences in the context of official institutional constraints" ${ }^{\prime 3}$.

E. Shills offers another frame, he advocates the principle of political determinism as determinant in the system of society. "The main factors that create and preserve society are central government, consent and territorial integrity"4. In such position there is a rational component. The transition from pre-industrial to industrial society is accompanied by the collapse of the system of traditional forms of social regulation, the state of social "anomie", while new mechanisms of regulation and regulation of social relations are only being drawn up. In these circumstances, the power-political factor, forming the system of legislative, executive and judicial power, plays an important role, the whole process of social transformations, and often fate of the country itself, depends upon the action and interaction of which.

Ukrainian scientist A. Ablov believes that the defining principle of social determination is historic. In the industrial society there is economic

${ }^{3}$ Nort D. Institutions, institutional change and functioning of the economy. Kyiv: Gaydariki, 2000. 385 p.

${ }^{4}$ Shills E. Society and Societies: Macrosociological Approach. American Sociology. Prospects, problems, methods. Moscow: Progress, 1972. 392 p. 
determinism, in the industrial - political, and in post-industrial - cultural determinism. At the same time, in his opinion, the industrial society is a transitional stage from pre-industrial to postindustrial society, the effectiveness of which depends primarily on power and politics. So according to A. Ablov: "The strategy of social change should be based on knowledge of the laws and forms of functioning and development of social relations, their interactions and determinations in specific historical conditions and interrelationships of the past, present and future. If the traditional society was characterized by economic determinism of the interactions of social relations and spheres of life, then the socio-cultural factor in the post-industrial stage is becoming increasingly dominant. In fact, industrial society serves as a transitional phase to the post-industrial stage. The transition from the traditional to the industrial stage was characterized by the destruction of social order, the emergence of a state of social anomie, revolutionary social changes, and the establishment of political determinism in the system of interactions of social relations" ${ }^{5}$. The leading countries of European civilization passed the transitional stage of the industrial society in about two centuries, while the "Asian tigers", the countries of Southeast Asia for several decades.

Thus, the attitude of M. Weber, A. Toynbee, N., E. Schilz, A. Ablov in principle does not breach the methodology and logic of determinism, the principles of modernism.

Attempting to overcome this methodological contradiction makes O. Toffler, while emphasizing that the methodology of modernism continues to be useful, but it should be used only for the analysis of individual, simple in its content changes - as a methodology of simple systems.

The logic of causality of the systemic connections of the Third Wave Society is substantiated by O. Toffler on methodological principles that are close to the I.Prigozhin methodology. A.Galchinsky in this methodology considers it expedient to define such features: "... firstly, it is an understanding of causality as a system of complex (multi-vector) interaction of diverse in its nature forces; secondly, it is a need to identify not only direct but also opposite, positive and negative links; thirdly, it is an explanation of complex phenomena and processes based on a

${ }^{5}$ Ablov A.F. Some Problems of the Theory and Practice of the Transformation of Modern Ukrainian society. Herald of the Odessa National University. Series: Psychology. Vol. 23. Issue 2 (48). 2018. Odessa: "Astroprint". p. 7-22. 
combination of random and necessary; and fourthly, this is the assumption of self-exciting processes". ${ }^{6}$

Thus, the new methodology opens the way for the development of methodological construction, which is not in the mechanical denial of one another, but in their logical continuity, mutual enrichment.

Perspective in terms of overcoming existing methodological constraints can be considered a relatively new direction of research, which was called postmodernism, or concepts of "the postmodern modernity".

Of course, today it is impossible to speak of postmodernism as an already formed, relatively holistic theory. "It is too early to say that postmodernism is the basis of this methodology, but its antithesis to the logic of modern modernism, it is evident from the need for a careful attitude towards its basic postulates ${ }^{7}$.

Methodological contradictions between the principles of modernism and postmodernism relate primarily to the basic problems of determining the phenomenon of the present. It is about finding answers to questions about which phenomena of social life and its characteristics carry the essential features of a new society and which of them can be interpreted as obsolete social forms inherited from the previous stage and in the long term must be overcome. It is precisely postmodernism that focuses on the global divide between dying and asserted forms of society.

Most of the differences between the methodologies of modernism and postmodernism can be reduced to two aspects - rationality of human activities and problems of equilibrium and self-regulation of social processes.

Modernism focuses on the rationalism of human activity, on the material interests of individuals, while postmodernism pays more attention to the increasing role of moral-psychological, ethical factors of human activity in the modern world.

Regarding the equilibrium problem, modernism is based on the postulate in which society evolves to equilibrium, which is realized in an automatic mode, is based on the rationality of human activity, as well as on the principle of historicism: systemic transformations are realized on the trajectory - from non-equilibrium to equilibrium in the future, from

${ }^{6}$ Galchinsky A. Global transformations: conceptual alternatives. Methodological alternatives. Methodological Aspects: [Science Edition]. Kyiv: Lybid, 2006. 312 p.

${ }^{7}$ Ibid. 
equilibrium of the first order - to a more balanced equilibrium of the second order and so on.

In today's social realities, which have signs of deep system transformations, the principle of non-equilibrium development begins to dominate. The bifurcation point is a position in which the systemic equilibrium is denied. Therefore, equilibrium should be considered not as a universal constant, but as a specific situation, which: a) is always limited in space and time; b) is responsible only for simple systems; c) is considered as a separate case.

It is important to consider another methodological caveat. Modernism is organically linked with industrialism, capitalism, and the national and state organization of society, whereas postmodernism denies these basic postulates of the corresponding methodology, opposing to them the theory of complex non-equilibrium processes, the fundamental principles of which were formulated by representatives of natural sciences and mathematics.

Postmodernism focuses on the assertion of the individual, the subjective factors in social development. In the conditions of the preindustrial and industrial epochs, real life was a society, not an individual. In contrast to such an installation, according to the new methodology, a separate human person acquires the status of a reality capable of selfrealization and being known by itself. In the framework of this scientific direction, a methodological individualism is formed that focuses the attention of scientists on humanistic values, the self-realization of man, its dominant meaning in the system of society.

Much of the leading scientists in the field of social sciences see the overcoming of the scientific crisis in the constructive synthesis of theoretical studies of the entire spectrum of social sciences. "We learned in the process of theoretical analysis to dismember the problems of social development into constituents, and this in its time was a fundamental asset of scientific research. Nowadays the main task of social science is to assemble separate parts into a whole, to form the principles of generalizing theory, theory, more adequate logic of modern transformations" 8 .

${ }^{8}$ Galchinsky A. Global transformations: conceptual alternatives. Methodological alternatives. Methodological Aspects: [Science Edition]. Kyiv: Lybid, 2006. 312 p. 
Such formulation of the question has several arguments. It is, on the one hand, about the fundamental complications of the systemic connections of social processes and the difficulty of their holistic comprehension, which the modern methodology encountered, on the other hand - the impossibility of mastering without such an understanding the logic of individual processes that are only known as part of the whole, and not as segregated segments.

The essence of the problem of scientific synthesis concerns not just interdisciplinary cooperation, but a higher level of cooperation - mutual enrichment at the methodological level, the formation of the systemic integrity of cognitive process on the basis of the logic of methodological monism with emphasis on sociologization and humanization of all sciences.

\section{System approach as a necessary condition for the formation of methodological foundations for the transformation of modern Ukrainian society}

Despite the existing variety of theories and their methodological foundations, the method of systematic approach remains the basis of scientific methodology, which at the same time serves as a way of logical thinking, system perception and appropriate information ordering. Systemicity is also an integral part of the management of complex objects.

System analysis is based on the law of complex (integral) systems, according to which the whole is greater than the sum of its parts. A holistic complex system differs from the summation (simple) formation of subordinate systemic links between constituent elements and assertions of systemic quality. In this case, the system principles of functioning and development become the dominant ones. Such a system is self-sufficient, working on the basis of its own (system) laws, requirements of which are subject to its structural components.

However, it is essential to keep in mind that in the system integrity, their own qualitative values of the constituent structures do not completely disappear. Subordinating to the whole, they at the same time maintain their relativity. Power system, the contradictions of its development is formed on the basis of the corresponding interaction.

It is important to understand that these definitions are not abstract; they are easily projected onto real social processes and can be used as methodological principles of cognition. An example of this is the process 
of forming the structural integrity of the global system. It is well known that the history of human civilization is marked by the unity and interdependence of development. Mankind has always been the only one. And this union took place even when relations between nations and peoples on their external features did not only failed to receive a clear manifestation, but also were antagonistically contradictory, developed in accordance with the principles of a simple system dominated by horizontal between segments (interstate) ties.

The fundamental novelty of the modern stage lies in the fact that civilization is developing in the direction of gradual overgrowth of the simple integrity of the world into a structural one. It is an extremely complex contradictory process, which in many aspects has not yet become consistent. The methodology of system analysis creates a sufficient basis for their scientific reflection.

The methodology of system analysis proceeds from the three-phase development of each functioning system:

- genesis, when the system is in the phase of summation (simple) integrity;

- maturity when the system becomes a structural integrity;

- a decline that occurs at a time when potential of the development of the system itself is exhausted.

Contradictions of development are changing into contradictions of decline, which cannot be overcome. This leads to the bifurcation of the system, its replacement by one or several new systems, which, on the one hand, are antipodes of their predecessors, develop on the basis of immanent (opposing) principles and laws, on the other - they are more complex in their structural construction.

Schematically, the development of the system can be presented in the form of the following steps: a) the formation of integral quality of the system; b) change of the properties of the structural components of the system, their subordination to the system integrity; c) formation of new integral structures, on the basis of which the functional qualities of the approved system are implemented.

Thus, the methodology of system analysis proceeds from the fact that each system is not only historical - it has its beginning and the end, develops within a certain space and its own historical time, and is based on the principles of self-development. The logic of historicism is the logic of historical self-development - development, which is ensured through 
the implementation of the internal energy potential of the system. For this study, this thesis is a starting point, since it allows one to combine the branches of public authority, power and self-government, defining the latter as the energy potential of the power system in society.

Ukrainian scientist A.Galchinsky indicates that the potential of selfdevelopment is formed on the basis of three types of contradictions. First, the contradictions between the whole and the individual structural elements of the system. Whole acts as a determinant of their parts, converts them according to their nature. The energy potential of the development of the system is formed primarily on this basis.

Secondly, the energy of development is growing not only on the basis of subordinate links between the whole and parts, but also on the basis of interaction between individual parts or groups of parts. It is said that, subjecting to the whole, separate structural elements in the stages of formation and development of the system actively counteract each other.

Thirdly, the energy of the system's development is generated from the external environment. The sign of the system is its relative closeness and limitations to the outside world. . This is a fundamentally important position. Only in the process of interaction with the external environment the system reveals its properties, its certainty, which do not allow it to dissolve in the environment, function and develop relatively independently 9 .

Thus, sources of accumulation of the energy potential of the system are its heterogeneity and contradiction. Systems remain meaningful only when the whole and system, the structural links of the system, and, finally, the system and the external environment are differentiated when heterogeneous integration of the system takes place, when the principle of hybrid enrichment is realized, on the basis of which system quality and energy potential of the system grows. . In a situation where a systemic integrity is achieved, when the relevant links become homogeneous, when the system acquires signs of homogeneity, its energy potential begins to decay. It becomes mutant, nonviable, vulnerable to external influences, loses the potential of self-preservation. Finally, the system, which achieves the relative homogeneity and structural identity of its components, decays; its differentiation, dismemberment occurs.

${ }^{9}$ See Galchinsky A. Global transformations: conceptual alternatives. Methodological alternatives. Methodological Aspects: [Science Edition]. Kyiv: Lybid, 2006. 312 p. 
In general, the system is considered to be life-sustaining when the energy of its internal connections (vertical and horizontal) exceeds the energy impact of the external environment. If the internal potential of self-development becomes less than the total energy of external influences, the integrity is destroyed from the outside and eventually collapses.

In this context, the methodology of system analysis delimits the functional laws - the laws of self-realization of the system within the limits of the available certainty, its essential quality and laws of development, which determines the mechanisms of qualitative transformations of the system, processes not only its formation and development, but also decline and disappearance.

Correspondingly, there are different types of contradictions contradictions in the development and contradictions of the collapse. Controversial development associated with the adaptive capabilities of the system; contradictions of the decay fulfill the opposite function. They lead to the death of the system, moreover, in the historical aspect, they are inevitable. The principle of historicism of the system is based on this inevitability.

However, new accents are now being set up, increasingly turning to the impossibility of new ideological foundations, a new culture of thinking. No one denies the importance of system analysis, but all state the appropriateness of reviewing systemic research. At least five positions in the new approach to systemic methodology are actualized at the present stage of development of social sciences, namely:

1) complex systems are primarily dynamic systems;

2) complex systems belong to a class of orderly systems;

3) according to the principles of functional complexity, it is precisely the transient systems that represent only one of the chains of the evolutionary process, a peculiar "prehistory" of the new, which only arises and is established. They are implemented through the mechanisms of bifurcation and chaos. The state of the bifurcation is identified with a deviation from the standard cause-and-effect determinism and equilibrium. The dominant development is an accident. Under chaos, this state of the system is understood; its memory in relation to the previous linearly deterministic state is completely lost. And the state of bifurcation 
and chaos as a state of disorder, according to I.Prigozhin, is a payment for the possibility of establishing a new order ${ }^{10}$;

4) the notion of complex is organically correlated with the specifics of the so-called dissipative systems, which exclude the possibility of reverse development, are based on the principles of the irreversibility of processes;

5) description of complex systems requires not deterministic, but probabilistic approach.

Modern society is an extremely complex system, consisting of many subsystems of different levels and complexity. The study of modern social processes requires the development of methodological foundations of theories, scientific paradigms, the application of a systematic approach, in which various theoretical and methodological concepts appropriate to the social nature of reality, which is the direct subject of the study, must be used. The system methodology and other approaches based on it should become the methodological basis for enriching theoretical researches of social processes, determining the place and role of numerical subsystems in modern Ukrainian society and their transformation in accordance with the needs of social progress.

When developing a new strategy, it is necessary to take into account the existing contradictions between classical science, education and modern innovation trends that can be overcome only by preserving the best traditions along with the systematic implementation of the latest technologies into the social practice of transforming modern Ukrainian society.

\section{CONCLUSIONS}

Describing the state of theoretical and methodological principles of scientific research of the transformational processes of contemporary Ukrainian society, it should be noted:

1) the growth of pluralism and the presence of numerous competing theories and paradigms of social development, each of which, depending on the specific conditions, may become a priority;

2) in the analysis of social processes, it is necessary to take into account not only the general strengthening of subjective factors associated with changes in the place of man in the social structure of

\footnotetext{
${ }^{10}$ Prigogin I., Stengers I. Time. Chaos. Quantum. Moscow: Nauka, 1998. 438 p.
} 
modern society, but also the modification of human nature, the growth of the range of its freedom and individuality, overcoming alienation;

3 ) the theory of complex non-equilibrium systems does not narrow in any way, but on the contrary - expands the prospects of scientific research, including political ones. These are the principles of denying the predictability of the future as a product of self-development. The future cannot be a pre-planned process. One can only express hypotheses regarding the development paths based on the use of quantitative data. However, the normative function of social sciences is not to construct the future reality, but to find out how it is formed, and at the same time, comparing social structures, to promote a more rational reality. However, it should be understood that such justifications will always be not only relative, but also those that have exclusive application in well-defined systems;

4) in modern science, the most important methods of scientific research are revised, in particular the principle of scientific abstraction and the principle of combining logical and historical approaches in the study of social processes. Questioned the correctness of the widely used in modern research tools of analysis of the logic of ascending development, the movement from the simplest elementary forms to mature systems. It is believed that any characteristics of the simplest form of the social process in the best case explain the past and in any case not modern;

5) at the present moment in the social sciences the question arises of the essential reorganization of the existing mechanisms and methods of scientific knowledge. The methodology itself undergoes significant changes. Old methodological canons no longer work, and new ones do not work yet - they are not systematically formed. Principal challenges to the modern scientific process give rise to crisis phenomena in the field of scientific research. The problems of science are reflected in the social practice of the transformation of modern Ukrainian society.

\section{SUMMARY}

The paper deals with theoretical and methodological approaches to the study of the transformational processes of modern Ukrainian society. The author analyzed the existing social theories and scientific paradigms in which the search for the most adequate methodological principles of transformational social changes aimed at sustainable and accelerated 
development corresponding to the features of the post-industrial stage of society was carried out in world and Ukrainian scientific activities. It is argued that the peculiarity of modern social development is its crisis situation, the uncertainty of the future and, at the same time, the crisis of social sciences, their theoretical and methodological principles. All this complicates the resolution of the problems of qualitative transformations in post-communist countries, Ukraine in particular. Further studies of the transformational processes of modern Ukrainian society, as argued by the author, should be based on the systematic approach methodology.

\section{REFERENCES}

1. Vovkanich S.Y. Socio-humanistic paradigm of the integration strategy of Ukraine and its regions. Regional economy. 2008. No. 3. P. 7-22.

2. Nort D. Institutions, Institutional Change and Functioning of the economy. Kyiv: Gaydariki, 2000. 385 p.

3. Shills E. Society and Society: Macrosociological Approach. American Sociology. Prospects, problems, methods. Moscow: Progress, 1972. $392 \mathrm{p}$.

4. Ablov A.F. Some problems of the theory and practice of transformation of modern Ukrainian society. Herald of the Odessa National University. Series: Psychology. Vol. 23. Issue 2 (48). 2018. Odessa: "Astroprint". p. 7-22.

5. Galchinsky A. Global transformations: conceptual alternatives. Methodological Aspects: [Science Edition]. Kyiv: Lybid, 2006. 312 p.

6. Prigogin I., Stengers I. Time. Chaos. Quantum. Moscow: Nauka, 1998. $438 \mathrm{p}$.

Information about the author: Dunayeva L. M. Doctor of Political Science, Professor, Odesa National I. I. Mechnikov University 15/13, Tenistaya str., Odesa, 65009, Ukraine 


\section{DYNAMICS OF SOCIO-POLITICAL DEVELOPMENT OF MODERN UKRAINE IN THE CONTEXT OF PRIORITIES OF LIBERAL DEMOCRACY}

\section{Hedikova N. P.}

\section{INTRODUCTION}

A democratic project and basic liberal values and principles were laid as the basis for the establishment of independence and the creation of an independent Ukrainian state with the enactment of the Declaration on State Sovereignty of Ukraine (1990) and the Act of Independence of Ukraine (1991). We have confirmed our choice of the civilization vector of development.

Ukraine have had the challenge of extraordinary complexity: to build state institutions, create conditions for the development of civil society, consolidate society around the national idea, that are able to constantly develop and improve the nature of their actions.

Among the weighty reasons that caused the transformational failure of Ukraine, there is a multidisciplinary policy that hasn't made it possible to clearly define the course of strategic development; distortion of democratic procedures; defamation of the electoral system as the main instrument of rotation of power and the mechanism of formation of representative bodies of power; prolonged internal political instability; lack of interaction between the state and civil society. This led to disorganization, growing distrust of the state from the side of society, the escalation of tension within the country.

The Revolution of Dignity and Ukraine's ratification of the Association Agreement with the EU have become a factor in changing state policy, a vector for the development of Ukrainian statehood and all its system-building institutions and civil society. It's focused on the European component of Western civilization dynamics, taking into account the peculiarities of the mentality, culture, spiritual state of the Ukrainian nation and in general, its own state-building experience. These events contributed to the process of transition of Ukraine to a new phase of civilization development. It based on the basic provisions and priorities of the liberal-democratic model of socio-political system. 
We conclude that significant changes need a scientific political science in the development of the Ukrainian state. It will allow us to predict the prospect for further development, which determines the relevance of the proposed research.

\section{Liberal Democracy as a model of the socio-political structure of the state}

The civilization is caused by the victory of the Western bloc in the Cold War. It has undergone serious changes in the last decades of the twentieth century, that have been manifested in the approval of the unipolar orientation of world development, modernization processes in a number of democratic states, and in post-socialist countries. That changes are oriented towards a Western model of state. One of the leading thinkers of the world, philosopher F. Fukuyama described these changes as the end of ideological confrontation and the victory of the ideas of liberal democracy in his essay "The End of History and the Last Human"1.

Liberal democracy was formed in the process of synthesis of liberalism and democracy. Proceeding from the fact that we consider it appropriate first of all to turn to the definition of their essential characteristics and consideration of the criteria for their relationship and interaction. This will enable us to identify the essential characteristics and priorities of modern liberal democracy.

Focusing on the democratic project of institutionalizing the structure and dynamics of the development of political systems, we must realize that liberalism is a historical and philosophical trend, a doctrine and a political ideology. It justifies programmatic arrangements. So, a mass organized movement (liberal political parties, movements, groups etc.), as well as civilization model of public welfare. Democracy isn't ideology, but it's the form of government, the model of state and society, which involves the formation of the necessary conditions to ensure a decent human existence.

Obviously, on the one hand, democracy is intended to ensure the implementation of liberal values. It requires the creation of representative parliamentary democracy and the administration of the state on the basis

${ }^{1}$ Фукуяма Ф. Конец истории и последний человек [пер. с. англ. М. Б. Левина]. Москва: АСТ. 2014. 592 с. 
of the constitution. On the other hand, it needs to be liberalized due to the fact that democracy in its pure form is capable of reaching extreme manifestation. The result of their rapprochement and interaction is liberal democracy. G. Ruggiero says: "Where the adjective is "liberal", it has limitations and serves as an emphasis on the need for detail and differentiation, which is felt in the oppressive and devoid of vital energy of the monotony of a democratic society"2.

There is the main difference between the two political doctrines under consideration. Political liberalism is predominantly oriented on legal norms, the priority of the individual in relation to the collective and the state. Democracy is based on the free expression of the will of the people, or the majority of the opinion in determining the political, economic, social and cultural nature of the system, on the general right of all citizens to a part of political power. In this case, the common will and will of each citizen must coincide in a democratic state. Accordingly, the majority board should be consistent with the provision of individual human rights, which determines the procedures for protection and the mechanism for the exercise of minority rights.

Human as a social element is seen as an autonomous individual (personality) in liberalism, but in a democratic doctrine as a citizen. These constants determine the sphere and place of manifestation of his activity, the resources that he can dispose of.

The convergence of liberalism and democracy consists in the fact that they consider an individual as a citizen who has the right to participate in the political process, in the exercise of political power, in direct participation in the development and adoption of laws, in the definition of a common policy, in political decision-making through general voting and people's representation. They provide for the existence of norms that determine the legitimate means of coming to power and regulate the actions of the institution of power (including each of its subjects at all levels) from according with the values of the country and the will of the people. Both doctrines based on the fact that it can provide the individual complete independence and autonomy in judgments, expression of will and active participation in the political and socio-cultural processes of social development. The principles and values

2 Руджеро Г. Лібералізм і демократія. Лібералізм: антологія. Упоряд. О. Проценко, В. Лісовий. Київ: Смолоскип, 2002. Х +. С. 1031. 
of liberalism and democracy are reflected and specified in the institutes of civil society. Liberalism and democracy aren't commensurate with permissiveness. They predict that the resolution of emerging disputes and controversies and the adoption of necessary decisions should be carried out by an independent judiciary within the legal framework.

The liberal democratic theory has an important feature. It considers liberalism as an order, which is based on the rules of law and legality. Its ideologists focus on individuals who are given priority in the process of making policy decisions in order to avoid the concentration of power in one instance. In this position, liberal democracy reinforces the importance of the theory of human rights. Social collective is considered as a necessity (taking the value of an instrument), which can guarantee and provide to each individual the protection of his rights and freedom in relations with other individuals by its decisions and actions.

Priority in the hierarchy of values of liberal democracy remains the freedom of the individual, which has its own boundaries. It's defined by law, and commensurate with responsibility. This position finds its rationale that in essence the person is an atomic substance of the social whole, therefore, its actions cannot bear the nature of permissiveness. In contrast to democracy, freedom is interpreted not as active participation in politics, but as the freedom of personal interests of citizens, which is not subject to restrictions and coercion by other social actors and social institutions. It also doesn't depend on political power.

It is indisputable that the source of democratic power is the people. In this regard, we share the opinion of Ukrainian researcher M. Sazonov, who believes that "the "people" of liberal democracy have other dimensions, characteristics and ways of realizing the functions of the sovereign power in comparison with the "people" of the classical liberal theory" ${ }^{3}$.

It is argumented by the following evidence. First, M. Sazonov believes that "people" now is much more burdensome than it was one or two centuries ago. Liberal democracy is based on the fundamental principle of "people - the supreme sovereign". It overcomes the restrictions of Western democracies in the nineteenth century, and in

${ }^{3}$ Сазонов М. Ліберальна демократія - модель державного устрою країн Заходу. Порівняльна політика. Основні політичні системи сучасного світу. За заг. ред. В. Бакірова, М. Сазонова. Харків: ХНУ імені В. Н. Каразіна. С. 95. 
some cases, in the middle of the twentieth century. The property, demographic and other qualifications were stored, without which a person did not have the right to vote, and also dispersed the narrow framework of the "people".

Secondly, the author observes that electoral systems in force in Western democracies are contributed to a more complete and effective implementation by the people of their function as the supreme power bearer. These systems have both similarities and differences due to the prevailing type of political culture of the nation. At the same time, all electoral systems in a democratic society should correspond to the history of the country and its traditions. An obligatory requirement for electoral systems is to be "transparent" and to place confidence in the ability to check the results.

Thirdly, liberal democracy has acquired the qualities that allow it to more fully and effectively influence the power. Today, he not only differs from the people of ancient democracies and modern totalitarian states, but also in many ways specific to the "people" of Western democracies, which he had in their classical liberalism. Therefore, M. Sazonov makes the conclusion. On the one hand, it is a people whose diverse interests are recognized as lawful. In fact, their human nature is realized. This is the basis of pluralism, which is a "living soul" of a liberal-democratic system. On the other hand, it is a people who are a complex structure, which is not just the sum of individuals with diverse interests, a number of socio-demographic communities and three or four generations, but also many social strata, whose interests articulate and protect political parties, corporate associations, social movements, interest groups, as well as various social and civic organizations ${ }^{4}$.

Unlike democracy, liberal democracy defends the recognition and observance of minority rights and their institutionalization. As a method of exercising power, it does not crush the minority, as opposed to democratic rule (which in turn does not preclude the guarantee of minority rights), but it allows to realize its interests. Thus, minority is the main determinant and driving force of the political process. It's satisfied the interests of the whole society. This is based on this principle, liberal

${ }^{4}$ Сазонов М. Ліберальна демократія - модель державного устрою країн Заходу. Порівняльна політика. Основні політичні системи сучасного світу. За заг. ред. В. Бакірова, М. Сазонова. Харків: ХНУ імені В. Н. Каразіна. С. 95-98. 
democracy provides a process for their implementation, mainly due to the priority of the interests of the individual and society over the interests of the state. The state is a guarantor of stability and the dynamic development of society. It ensures adherence to the rule of law, principles of social justice, is a controlling and protective social institution.

In turn, society in liberal democracy is seen as an open system in which each individual. It has the right to integrate into different base groups, who can adequately present his concept of the political truth of the goals and on equal grounds to fight for their implementation. This approach suggests that liberal democracy is based on pluralism. In this context, M. Sazonov says that "... the group acts as the main driver of politics. Interested groups are a central element of a modern democratic system that guarantees the realization of interests, human rights and freedoms. The logic is that an individual without a group lacks abstraction. A person is formed only in the group and intergroup relations. The interests, values, motives of behavior and political activity are crystallized. A person gets an opportunity to identify and protect his interests as a part of a group",5.

Liberal democracy plays a decisive role in the question of the progress and effectiveness of society development, giving a market and individualistic orientation in the economy. The fundamental foundation for the successful development of liberal democracies is private property and competition as a means of ensuring equal opportunities and a method of excluding the monopolization of public resources. Liberal democracy appeals to a liberal approach, according to which a society of equal opportunities. It is based on the principles of social justice (equality of rights, which is comparable to responsibility, and equality of starting opportunities) and social solidarity of all its citizens.

Also, the main priorities of liberal democracy are guaranteeing the constitutional rights and freedoms of human and citizen, a developed system of justice, the presence of a broad middle class, freedom of speech and the media, and so on.

The interaction between democratic, liberal and liberal-democratic values are always balanced in democratically-formed political systems.

${ }^{5}$ Сазонов М. Ліберальна демократія - модель державного устрою країн Заходу. Порівняльна політика. Основні політичні системи сучасного світу. За заг. ред. В. Бакірова, М. Сазонова. Харків: ХНУ імені В. Н. Каразіна. С. 98. 
These models are the provision and development of a comprehensive spectrum of human rights and freedoms, the rule of law, popular sovereignty through representative government, the inviolability of the distribution of functions of the legislative, executive and judicial branches of power, the priority of individual interests, civil society over the interests of the state. The priority is the right, freedom, equality among the wide range of value systems in each of them.

The highest social values of the rule of law are human and the rule of law. It should be emphasized that the latter is a derivative of the first, due to the fact that the right is a mechanism for ensuring decent life and human development. Proceeding from the principle of primacy and the rule of law, all its subjects (individual, state, civil society, institutions of power, nation, national minorities, etc.) are subject to him. This principle establishes the beginning and end (that is, sets boundaries) of the legal entities, which oblige them to behave in accordance with legislative and regulatory provisions; legally rationally and reasonably restricts the independence of the state, civil society and its institutions, as well as human freedom. These limits form the basis of constitutional provisions.

Human rights are a valuable standard that provides individuals with free development and self-determination in equal conditions. They have equal opportunities to participate in the selection and formation of a vector of social and state development, an integral element of social relations and the existence of personality.

These models advocate the concept of basic value, which is the freedom of the individual (personal/individual freedom). That determine its significance and the need to liberate a person from all forms of oppression by social institutions. Personal freedom refers to civil liberties - the fundamental rights underlying which are natural law. Civil liberty is a guaranteed opportunity for the law to enjoy the fundamental rights of a person and a citizen, whose recognition and safeguarding of a legal state must be built.

Political freedom means free political will in complying with the laws, as well as the right of every citizen to participate in the management of the state and social structures through democratic procedures, advocate for radical reforms, freely express their views and try to convince them of other people. At the same time, political freedom is seen as an addition to civil liberty as its guarantee. 
The key to spiritual freedom is freedom of speech, conscience, the right to free choice of beliefs and beliefs, free scientific creativity, research, philosophical freedom, freedom of love, sexual freedom, etc. Spiritual freedom is directed to the internal self-management of man, independent, independent development and spiritual perfection.

Material freedom is the improvement of relations that arise in the process of production and distribution of goods. This is a guarantee of the independence of the individual from the collective and social life, and the condition necessary for normal, natural existence. The true sense of freedom is largely determined by the respective economic and material capabilities of each.

All kinds of freedom are in legal mediation, that is, they accept the legal form of expression of freedom, which is realized within the limits of the general moral principles permitted and established by the normative and legislative acts created to protect the interests of man and the state. The theory of "freedom from" and "freedom to" is justified by classical liberalism with classical legal thought. It has already foreseen and pointed to the inevitability (as a natural law of development) of formal legal equality and certain types of inequality (educational, social, economic, etc.). And they did not lose their significance in the process of evolution of civilization, but only switched to a new, more complex state, thus becoming the most important factor in socio-legal relations.

Equality is not an abstract, but a formal one in the models under consideration. All people are equal on a personal level. They advocate a position that people in society may be equal before the law in obtaining civil rights, property rights, etc., but they cannot be equal in their mental and physical capacities. In this way, they insist that the law should take into account equal individuals, both by origin and by abilities. At the same time, providing equality should not restrict of starting opportunities, legislation the rights of people more capable.

Relying on the idea of the same value of each individual, the category of equality is understood as the equality of initial opportunities. It doesn't inequality in the distribution of profits, equality of rights and opportunities for each member of society, while not ignoring the actual (economic and social) inequality of people. Social justice is understood, on the one hand, as the equality of all citizens before the law, on the other hand, as the equality of individuals in moral, political, legal, economic, national-cultural and other rights. The above-mentioned models of 
achievement of true order in society and the state are seen only on the basis of the rule of law and law.

Consequently, liberal democracy is a model of the socio-political system, the form of government and the social organization of life, in which, based on the rule of law, maximum conditions are created for selfdevelopment and self-realization of the individual.

\section{Specific of socio-political development of modern Ukraine}

The Constitution consolidates Ukraine in the status of a sovereign independent, democratic, social, rule of law, whose policy is aimed at creating conditions conducive to decent living and the free development of man.

Article 3 of the current Constitution of Ukraine says: "Human rights and freedoms and their guarantees determine the content and direction of the state's activities. The state is responsible to a person for his activities. The assertion and guarantee of human rights and freedoms is the main responsibility of the state" 6 .

The main task of the state is to fill the actual content of the personal, political, economic, social and cultural rights and freedoms of human and citizen. It's proclaimed by the Ukrainian legislation, creation of the necessary conditions and guarantees of their provision, construction of mechanisms for their protection and realization.

The main mechanism is the rule of law in the system of ensuring the fundamental rights and freedoms of man and citizen. A prerequisite is the rule of law and order for the existence and operation of this mechanism. In aggregate, these factors form the legal basis of real democracy, concentrate all positive features of legal regulation of state and social relations.

The state of ensuring the rights and freedoms of human and citizen as the object of constitutional and legal regulation in modern Ukraine shows that there are problems with their implementation and protection to date and, alas, there are quite a lot of them. It usually takes place in the context of the rule of law, the rule of law and law and order. It should be noted in this regard the opinion of Ukrainian scholars-lawyers O. Litvak and P. Shumsky. They say that the disregard for the law and ignoring its

${ }^{6}$ Конституція України від 28.06.1996 № 254к/96-ВР. Відомості Верховної Ради України. 1996. № 30. Ст. 141. 
norms was a characteristic feature of contemporary social relations. In this situation, law enforcement and other state bodies gross violations of public order and other facts of lawlessness. The rule of law in the country is negatively affected by the lack of a clear mechanism for the implementation of laws, which irresponsibility and low discipline, creates a favorable environment for the robbery of the state, corruption, bribery, the formation of negative opinion in society and the loss of citizens in law enforcement bodies ${ }^{7}$.

The structural components of a democratic rule of law are institutions of public authority. They are based on the priority of the interests of citizens, through whose effective activity the rights and freedoms of a person can be protected and implemented to the extent necessary, the principles of a liberal democratic model of government.

The institute of power in modern Ukraine is structured in accordance with the democratic principle of separation of powers horizontally and vertically, according to a number of parameters, answering liberaldemocratic laws: political pluralism; decentralization; sovereignty and independence of power; elections, referendums and other forms of direct democracy as mechanisms of influence on state policy; consolidation of the political rights and freedoms of citizens in the Constitution.

The principle of distribution of power implies the separation of each of its components as an independent system. It is understood not as a simplified delimitation of competence between different systems of bodies, but as the fulfillment of each of them functions in the field of social life. Their activities are directly related. At the same time, the branches of power balance each other and interact with each other. This key democratic principle is enshrined in Article 19 of the Constitution of Ukraine: "The legal order in Ukraine is based on the principles under which nobody can be compelled to do what is not provided for by law. The bodies of state power and bodies of local self-government, their officials are obliged to act only on the basis, within the limits of authority and in the manner envisaged by the Constitution and laws of Ukraine" ${ }^{8}$. Accordingly, they are managed by the state.

7 Литвак О., Шумський П. Проблеми впровадження Закону України «Про прокуратуру» від 14 жовтня 2014 року. Вісник Нащіональної академї прокуратури України. 2015. № 1(39). С. 5-6.

${ }^{8}$ Конституція України від 28.06.1996 № 254к/96-ВР. Відомості Верховної Ради України. 1996. № 30. Ст. 141. 
Thus, it should be emphasized that within the framework of the Basic Law of Ukraine, the structure of power has received a well-ordered and hierarchical characteristic, although in reality the democratic principle of the division of functions and powers of power is not always respected.

In order to evaluate the activities of state, it is expedient to turn to the definition of the level of trust to them of Ukrainian citizens. Thus, according to the results of a nationwide population survey (which was conducted by the sociological service of the Razumkov Center from 21 to 26 March 2019), 2017 respondents aged 18 and over in all regions of Ukraine took part. The Crimea and the occupied territories of Donetsk and Lugansk regions didn't take part. Ukrainian citizens trust more in volunteer organizations (they are trusted by $68 \%$ of respondents), the Church (61\%), the Armed Forces of Ukraine (61\%), the State Emergency Service (57\%), volunteer battalions (56\%). The institutions of the state, which are more likely to express trust than distrust, also include the State Border Guard Service (it is trusted by 52\% of respondents, 33\% do not trust it), the National Guard of Ukraine (49\% and $35 \%$ respectively), the mass media of Ukraine (respectively $47 \%$ and $41 \%$ ), public organizations (respectively $46 \%$ and 39\%). Nonconfidence is most often expressed by the Verkhovna Rada of Ukraine (82\% do not trust it), the state apparatus (officials) (81\%), the Russian media (79\%), political parties (76\%), the judiciary $(75 \%)$, the Government of Ukraine (74\%), commercial banks (72\%), prosecutors' offices (71\%), the President of Ukraine (69\%), the Specialized AntiCorruption Prosecutor's Office (69\%), the National Anti-Corruption Bureau of Ukraine (NABU) (68\%), the National Agency for the Prevention of Corruption) (68\%), the Supreme Court (67\%), local courts (67\%), the Anti-corruption court (66\%), the Constitutional Court (65\%), the National Bank of Ukraine $(63 \%)^{9}$.

We can conclude of the high level of mistrust of Ukrainian citizens to the institutions of public authority, the judicial and law-enforcement system, and law. It is due to the fact that people were satisfied with the expectations of positive changes after the Revolution of Dignity, but after

9 Рівень довіри до суспільних інститутів та електоральні оріснтації громадян України. URL: http://razumkov.org.ua/napriamky/sotsiologichni-doslidzhennia/rivendoviry-do-suspilnykh-instytutiv-ta-elektoralni-oriientatsii-gromadian-ukrainy-2 
five years from the time of its implementation they haven't met the expectations of building a new type of state in Ukraine.

The essence of state power is the will of the whole society in accordance with liberal-democratic principles. It follows that state power is a unified system consisting of a structural internal organization and an expression of national interests. Bodies of state administration and local self-government aware that the state authorities are not able to take into account the complex diversity of problems and interests of Ukrainian citizens at the regional and local levels and react adequately to them. De-concentration and decentralization power are considered by them one of the main tendencies of political-power relations in modern Ukraine. In this connection, the emergence of a new model of functioning of public power is becoming relevant, which allows creating an institution of real democracy, of which priority is given to local and regional selfgovernment and regional and municipal governance.

Being a connecting link between the state and civil society, the structures of local and regional self-government give the priority to a sovereign individual, protecting its freedoms, rights and interests, essentially designed to bring power (as a mechanism of governance) to the people, to give communities the opportunity freely and responsibly solve the tasks facing them. In turn, this involves expanding local autonomy.

There was a need for reform the system of local self-government and the administrative-territorial structure of the state through the implementation of municipal reform in accordance with the emphasis placed in the issues of clear legislative and normative definition of the powers and responsibilities of public authorities, from the beginning of the declared in the current Constitution of Ukraine (1996) and definitively defined in the Law of Ukraine "On Local Self-Government" (1997). With the enactment of these documents certain steps have been taken in the issue of decentralization of power, a radical change in the system of governance and its territorial basis at all levels began to emerge in 2014 with the enactment of the Concept of Reform of Local Self-Government and Territorial Organization of Power in Ukraine.

There are the transfer of powers and finance from the state to local governments as a result of the enactment of the Concept and the introduction of amendments to the Budget and Tax Codes of Ukraine. So, 
"local budgets in recent years have grown by 165.4 billion UAH: from 68.6 billion in 2014 to 234 billion UAH in 2018 "

After the enactment of the Law of Ukraine "On Voluntary Association of Territorial Communities" of 05.02.2015 № 157-VIII, the Government has begun and successfully implemented the first stage and proceeded to the second stage of the reform on the issue of decentralization of power. According to the Press Center of the "Decentralization" initiative, we can say that this law "has allowed us to begin to form a capable base level of local self-government. From 2015 to 2018, 878 united territorial communities (UTC) had been created in Ukraine. These UTC comprise more than 4,000 former local councils. 9 million people live in UTC. Such international inter-municipal consolidation rates are called by the international experts very high. The law also introduced the Higher Education Institute in UTC, representing the interests of rural residents in the community council. There are already 786 elders working in the UTC villages, and almost 1,7 thousand of them are acting as chiefs. In 2018, united communities received in the communal ownership of almost 1.5 million hectares of agricultural land outside the settlements" $" 11$.

According to the Article 9 of the Law of Ukraine "On voluntary association of territorial communities" the state provides information and educational, organizational, methodological and financial support. Local state goverments provide organizational support and information and educational assistance to the voluntary association of territorial communities and joining the united territorial communities ${ }^{12}$. Thus, "state support for regional development and community infrastructure development has increased in 39 times during the reform period: from 0.5 billion in 2014 to 19.37 billion UAH in 2018.So, more than 10 thousand projects were implemented in regions and communities in 2015-2018"

This data allow us to apologize that the new model of financial support of local budgets has met the expected results underlying the decentralization reform in Ukraine.

\footnotetext{
${ }^{10}$ Об’єднані територіальні громади. Децентралізація. URL: https://decentralization.gov.ua/about

${ }^{11}$ там само.

12 Про добровільне об'єднання територіальних громад. Закону України від 05.02.2015 № 157-VIII. Відомості Верховної Ради. 2015. № 13. Ст. 91.

${ }^{13}$ Об'єднані територіальні громади. Децентралізація. URL: https://decentralization.gov.ua/about
} 
There is a sufficiently wide network of social institutions at present in Ukraine. Evidence of the results of the practical implementation of the state social policy is the indicators of material well-being of the population of Ukraine and a high degree of socioeconomic inequality, social migration, declining health and life expectancy of individuals, demographic factors, quality of education and medical care, the state of culture. We give some indicators which have been provided by the State Statistics Service of Ukraine in the period from 2015 to 2019 . We take into account precisely this period, because we don't take datas from the temporarily occupied territories of the Autonomous Republic of Crimea, Sevastopol and parts temporarily occupied territories in the Donetsk and Luhansk oblasts. In January 1, 2015, the existing population of Ukraine was 42928.9 thousand people, and as of April 1, 2019, it amounted to 42079.5 thousand people. The number of live births as of January 1, 2015 was 411.8 thousand people, and the number of deaths is 594.8, the difference was -183.0 . In 2018, the relevant indicators are: 364,0; 574.1 ; -210.1. The migration movement in 2015 amounted to 533278 people, respectively, in $2018-610687$ people $^{14}$. The folding socio-economic situation in the country indicates that in short-term perspective, it is unlikely that we will be able to gain positive dynamics. Ukraine is in a state of hybrid war with an external aggressor and having a temporarily occupied territory. So, it is very difficult to develop priority areas of life.

An equally important criterion is the presentation of mass consciousness about the values of human and civil rights and freedoms for characterizing the current state of socio-political development in Ukraine. Thus, Ukrainian experts say that freedom, justice and dignity continue to remain among the values of Ukrainians. There is the foundation of human rights, they are based on the data of a pollconducted by the I. Kucheriv "Ukrainian Sociology Service" company. According to which, freedom occupies first place (86\% of respondents mentioned it as the main value). The second place is held by justice ( $70 \%)$, the third is security (67\% of respondents). At the same time, security moved from the second to third place in the rating of core

14 Демографічна та соціальна статистика. Державна служба статистики України. URL: http://www.ukrstat.gov.ua/ 
values in two years. This explains the non-acceptance of undemocratic forms of Ukrainian government and various forms of pressure from the state $^{15}$.

Also, the Ukraine's value priorities were influenced by the change in the contemporary Ukrainian society of the common needs and interests that were conditioned by certain spiritual and moral principles. It formed on the basis of a new vision of the world, the rapid development of the latest technologies, the introduction of innovative models of economic development, civilizational choice of development, challenges the latest process of Ukrainian state-building and others.

Experts note that the population's assessment of the human rights situation. It has taken place since EuroMaydan remains pessimistic. Only $4 \%$ believe that the situation in this area has improved. In contrast, 34\% said that the situation was clearly worse, and another $29 \%$ thought that no changes had occurred. The overall assessment of the observance of various human rights varies between 2 and 3 points on a 5-point scale. The armed conflict in the East of Ukraine continues to affect the attitude of the population towards the observance of human rights ${ }^{16}$.

We share the opinion of Ukrainian scientist Y. Tyshchenko, who states that in the conditions of a loss of confidence in almost all state institutions and politicians, the role of civil society in the processes of transformation of society is particularly responsible, and the question of the interaction of power institutions with the public sector becomes stateowned $^{17}$. The events of the Orange Revolution strengthened the idea of citizens that they could influence the process of making political decisions and change the vector of socio-political development of the country. It based on the will of the majority. But political activity was only temporary. The events of recent years have taken place in Ukraine since 2014. They have shown that citizens have become more mobile, politically active and able to independently defend their rights and freedoms. These trends are evidence of the development and

${ }^{15}$ Колишко С., Паращевін М., Яворський В. Що українці знають і думають про права людини: оцінка змін (2016-2018). Резюме дослідження. Під заг. ред. Т. Печончик. Київ. 2018. С. 5.

${ }_{16}^{16}$ Там само. С. 6.

17 Яблонський В. М., Андріученко Т. В., Бекешкіна I. Е. та ін. Громадянське суспільство України: сучасні практики та виклики розвитку: аналіт. доповідь. За заг. ред. О. А. Корнієвського, Ю. А. Тищенко, В. М. Яблонського. Київ: НІСД. 2018. С. 18. 
consolidation of civil society. This is evidenced by data from the poll of the Democratic Initiatives Foundation named after I. Kucheriv. Thus, according to a survey of representatives of Ukrainian non-governmental organizations (NGOs) conducted by the Fund on February 14-17, 2019 ${ }^{18}$. All respondents agree that the Maidan gave a significant impetus to the development of civil society in Ukraine. At the same time, one third of respondents believe that civil society has already taken significant steps in its development. Somewhat smaller part believes that the Maidan has discovered new development opportunities, which under certain conditions may not be realized. According to the respondents, the Maidan intensified the civil activity of people, showed their capabilities and strength, multiplied "social capital" in society and developed selforganization skills.

Also, as a result of an expert survey, it was established that the current level of civil society is considered by the majority of respondents as average in Ukraine. The effectiveness is positively evaluated of the influence of NGOs on solving urgent problems of the state. A quarter of respondents are less optimistic and consider the influence of their organizations to be largely ineffective.

But we see that the majority of respondents consider it insufficient until the Maidan, but they admit that this influence increased significantly after the Revolution of Dignity. Immediately civil society had had the highest level of influence on power after the Revolution in 2014-2015, which slightly decreased over the next few years, but remained significant. Consequently, it should be noted that the development and strengthening of civil society has taken place. It becomes the dominant factor in social progress.

The democratic institutions are created by public organizations and associations, various unions, associations, trade unions. It ensures the legitimacy of the democratic process. Analysis of the dynamics of institutionalization of civil society is based on the data of the State Statistics Service of Ukraine in the period from 2014 to May 1, 2019 ${ }^{19}$. It

18 Чи стала Революція гідності рушієм розвитку громадянського суспільства експертне опитування. Фонд "Демократичні ініціативи» імені Ілька Кучеріва. URL: https://dif.org.ua/article/chi-stala-revolyutsiya-gidnosti-rushiem-rozvitku-gromadyanskogosuspilstva-ekspertne-opituvannya

19 Єдиний державний реєстр підприємств та організацій України. Державна служба статистики Украӥни. URL: http://www.ukrstat.gov.ua/ 
testifies the tendency to slow growth of the number of registered NGOs in Ukraine. On December 1, 2014 it was 75414; on December 1, 2015 it was 69,686; on December 1, 2016 it was 75,478; on December 1, 2017 it was 80112; on December 1, 2018 it was 84199; as of May 1, 2019, it was 86,015 NGOs. The number of other public groups was growing during this period. The main activities are the control over the activity of the authorities, the fight against corruption, the protection of civil rights and freedoms, socially vulnerable groups, as well as the protection of the natural environment.

One of the main factors is an economically stable civil society in the progressive development of a social and legal state, where most of the population is middle class. Experts note that the number of CEP countries in Ukraine is an order of magnitude lower than its number in developed democracies, which is at least $60 \%$.

So, we conclude that there was a positive in the socio-political development of Ukraine in the period of 2014-2019 in the context of the priorities of liberal democracy.

\section{CONCLUSIONS}

Ukraine has set an ambitious target for its development path and already tore its path to the priority principles of a liberal-democratic model of socio-political system since the implementation of the Revolution of Dignity and regulatory consolidation of interaction with the European Union in the format of association. This path is based on the subjectivity of Ukraine. It's the ability of the state to decide independently on the choice of the form and model of its national-state development in accordance with national interests, to take an active part in the formation of international politics, in the processes of globalization, in the formation of a new system of international relations.

New Ukraine is based on the principles of sustainable development, rule of law, protection of human rights, democracy, solidarity, good governance. For the last years of Ukraine's development, it became clear that Ukrainians are quite clearly aware of their own values, determine the priorities of their own country. They are ready to act in defense of their rights, freedoms and democracy.

The irrevocability of change is ensured by active participation of the public. Ukrainian citizens had become an active subject of power and 
legal relations, motivating the choice of methods and means of state governance and the formation of civil society institutions in recent years.

It should be noted that there is still a tangible negative effect of reforms positively evaluating the dynamics of Ukraine's socio-political development during 2014-2019 in the context of the priorities of liberal democracy. The state is now fragmentation of economic reform, slow implementation of judicial reform, reform of state funds, anti-corruption reform in Ukraine.

Incomplete reforms (chaotic and unsystematic mechanisms) is a threat to undermine confidence in public authorities and increase socioeconomic tension in society. The negative trends have emerged in Ukraine. But overcoming it is possible only through the systematic modernization of the whole complex of relations and institutions in the coordinate system of the state - society - a person.

In our opinion, Ukraine is part of the Eastern European culture and civilization community. The European choice of development is based on the priorities of the Western model of liberal democracy. It is undoubtedly justified.

\section{SUMMARY}

This article is considered essential characteristics and criteria of the relationship and interaction of democracy and liberalism. There is determined and analyzed the priorities of modern liberal democracy in comparison with democracy and liberalism. It is argued that liberal democracy as a model of socio-political system, the form of government and the social organization of life based on the rule of law creates the maximum conditions for self-development and selfrealization of the individual. There are analyzed the peculiarities of socio-political development of modern Ukraine in the context of the priorities of the liberal-democratic model. The emphasis is on state institutions, the reform of local self-government and territorial organization of power, the state and capabilities of civil society in Ukraine. The article is offered the author's generalizations and conclusions about comprehension of modern development of Ukraine as a new independent state of Eastern Europe. It's projected the prospect for further development of the Ukrainian state. 


\section{REFERENCES}

1. Фукуяма Ф. Конец истории и последний человек [пер. с. англ. М. Б. Левина]. Москва: АСТ. 2014. 592 с.

2. Руджеро Г. Лібералізм і демократія. Лібералізм: антологія. Упоряд. О. Проценко, В. Лісовий. Київ: Смолоскип, 2002. Х +. C. $1026-1032$.

3. Сазонов М. Ліберальна демократія - модель державного устрою країн Заходу. Порівняльна політика. Основні політичні системи сучасного світу. За заг. ред. В. Бакірова, М. Сазонова. Харків: ХНУ імені В. Н. Каразіна. С. 80-117.

4. Конституція України від 28.06.1996 № 254к/96-ВР. Відомості Верховної Ради Украӥни. 1996. № 30. Ст. 141.

5. Литвак О., Шумський П. Проблеми впровадження Закону України «Про прокуратуру» від 14 жовтня 2014 року. Вісник Національної академії прокуратури Украӥни. 2015. № 1(39). С. 5-10.

6. Рівень довіри до суспільних інститутів та електоральні орієнтації громадян України. URL: http://razumkov.org.ua/napriamky/ sotsiologichni-doslidzhennia/riven-doviry-do-suspilnykh-instytutiv-taelektoralni-oriientatsii-gromadian-ukrainy-2

7. Об'єднані територіальні громади. Децентралізація. URL: https://decentralization.gov.ua/about

8. Про добровільне об'єднання територіальних громад. Закону України від 05.02.2015 № 157-VIII. Відомості Верховної Ради. 2015. № 13. Ст. 91.

9. Демографічна та соціальна статистика. Державна служба статистики Украӥни. URL: http://www.ukrstat.gov.ua/

10. Колишко С., Паращевін М., Яворський В. Що українці знають і думають про права людини: оцінка змін (2016-2018). Резюме дослідження. Під заг. ред. Т. Печончик. Київ. 2018. 96 с.

11. Яблонський В. М., Андріученко Т. В., Бекешкіна I. Е. та ін. Громадянське суспільство України: сучасні практики та виклики розвитку: аналіт. доповідь. За заг. ред. О. А. Корнієвського, Ю. А. Тищенко, В. М. Яблонського. Київ: НІСД. 2018. 128 с.

12. Чи стала Революція гідності рушієм розвитку громадянського суспільства - експертне опитування. Фонд "Демократичні ініціативи» імені Ілька Кучеріва. URL: https://dif.org.ua/article/chi-stala-revolyutsiya-gidnosti-rushiem-rozvitkugromadyanskogo-suspilstva-ekspertne-opituvannya 
13. Єдиний державний реєстр підприємств та організацій України. Державна служба статистики України. URL: http://www.ukrstat.gov.ua/

\section{Information about the author:} Hedikova N. P. $\mathrm{PhD}$ in Political Sciences, Professor, Professor at the Department of Political Science and Law, State Institution «South Ukrainian National Pedagogical University named after K. D. Ushynsky» 26, Staroportofrankivska str., Odesa, 65020, Ukraine 


\section{OPPORTUNITIES OF E-LEARNING AT UNIVERSITIES IN UKRAINE IN THE OPINION OF TEACHERS (ACCORDING TO EMPIRICAL SOCIOLOGICAL RESEARCH)}

\section{Khyzhniak L. M.}

\section{INTRODUCTION}

With the development of e-learning, a special segment of the educational market - the market of e-learning services - is being formed, since there are both demand and supply of these services. Learning service is specific economic benefits provided to an individual (or a group) to meet a variety of educational needs as well as the product of collaborative work of teachers and students, which increases intellectual opportunities of the individual. The learning service should have benefits that can satisfy the consumers' needs related to obtaining the qualifications. Learning services meet personal (end-user), collaborative (enterprise-employer) and public (state, society) needs. Scientists classify learning services according to the ways of financing: as a public good, the production of which is financed by the state, and as a private good, the demand for which is determined by the existing purchasing power of users and the behaviors of families of applicants.

Learning services as a product of educational activity are the result of the implementation of a variety of activities (pedagogical, scientific, organizational and managerial) by educators to meet the educational needs of individuals and the society as a whole. Learning services belong to the group of creability products. These are products for which the buyer cannot establish the volume and quality or it involves very high costs. Due to the ambiguity of the learning services quality, there is an asymmetry of information between the seller and the buyer of services as for their quality; the development of the service coincides with the process of its consumption and is an integral part in time and spatial aspects (the exception is distance learning); learning service is not unified as a product; educational establishments sell their learning services at a price lower than costs when demand grows, subsidizing their consumers; services are not permanent. 
Materials of the empirical sociological study with contributions from the author can focus on the following tasks:

1. To define the commercial apeal of e-learning services entry into a market for Ukrainian universities according to expert evaluations.

2. To research estimates of demand in the labor market for specialists who have received electronic higher education according to expert evaluations.

3. To identify the potential target audience of e-learning at universities in Ukraine according to expert evaluations.

Basic concepts. Analysis of studies of the correlation between the educational market and the labor market allows us to focus on such aspects of the topic.

Firstly, in the modern world, against the background of the interconnection and interdependence of education, the labor market and the social behavior of individuals and groups, there is a tendency towards a gap between the sphere of education and the labor market. Scientists attribute this gap to a change in the "landscape of employment," with the capital of flexibility and mobility of representatives of the most soughtafter professions ${ }^{1}$.

Secondly, the educational services market and the labor market are beginning to link a new phenomenon - the recognition by scholars and practitioners of the need for lifelong education. Therefore, in conditions of flexible employment, the role of an individual's motivation to both receive quality education and continue it increases. As a result, attempts are being made to technologize the process of forming a positive motivation to learn from potential and real students in social and cognitive activity. The factors that determine the motivational positions of students most often include "the inability to plan their time well; excessive study load; not quite satisfactory quality of teaching in a number of disciplines, etc."2.

Thirdly, the introduction of electronic education is becoming a factor in the competitiveness of the university. Competitiveness indexes are

1 Попова Е. С. Горизонтальная профессиональная мобильность, профессиональное образование и рынок труда в России в динамике лет. Социологическая наука и сочиальная практика. 2018. № 1. С. 53-70.

2 Жукоцкая А. В., Васильев И. А. Мотивационные позиции студенческой молодёжи на образовательном поле. Вестник Института сочииологии. 2018. № 25. C. 78-99. 
gaining popularity, in which, in our opinion, the time has come to include e-education adoption indicators at universities ${ }^{3}$. The level of social competitiveness is capable of supporting and even enhancing an individual who, on the one hand, is motivated for continuous education, and on the other, can realize this motivational aspiration in the most accessible form, including in the form of electronic educational service. Trends in international higher education favor the dependence of an increasing number of universities (even highly rated) on foreign students. This situation leads to higher costs for universities to attract and train them due to the high competition in the educational market ${ }^{4}$. Since modern foreign students are representatives of the "digital generation", it is advisable for universities to offer them electronic educational programs.

Fourthly, globalization contributes to the development of the world labor market and the world market of educational services. Some researchers are calling on universities to stimulate the export of educational services, as it is today a trend in the development of the global market for educational services ${ }^{5}$. Sharing this point of view, we add the following: the export opportunities of e-education are enormous if their use is based on the real resources of the university and is supported by effective management in a particular university. Under these conditions, information about specific educational programs becomes more important, and not about the university as a whole ${ }^{6}$.

Fifth, research shows that the most individualized communications gradually crowd out direct interpersonal communication, which, of

${ }^{3}$ Немировский В. Г., Немировская А. В. Социальная конкурентоспособность: шансы на успех у молодежи и взрослых. Социологический журнал. 2018. № 2. C. 135-149.

4 Кемп. Нил. Новые тенденции международного рынка образования. Международное высшее образование. 2016. № 85. С. 19-21. https://ihe.hse.ru/article/ view/2941/2678.

5 Айдрус И. А., Горшкова Л. Ю. Особенности развития мирового рынка образовательных услуг на современном этапе. М. : Рос. ун-т дружбы народов, 2015. $320 \mathrm{c}$.

${ }^{6}$ Шэтток Майкл. Повышение информированности участников рынка: Рамочная программа улучшения качества преподавания (TEF) в британском высшем образовании. Международное высшее образование. 2018. № 92. С. 27-29. https://ihe.hse.ru/article/view/7564/8386. (accessed 10.05/2019). 
course, creates certain social risks ${ }^{7}$. At the same time, it is the electronic educational service that can best meet the educational needs of a particular student and correspond to his lifestyle. Individualization of education through the provision of electronic educational services by the university does not require the unity of place, time and action. This creates a special comfort in obtaining a university education.

The characteristic of e-university education is universality. Michael Barber, Katelyn Donnelly, Saad Rizvi offered modern universities several positioning options: an elite university; mass university; university occupying a certain niche; local university; lifelong university ${ }^{8}$. However, all the types of universities noted above may lose their competitiveness in a digital society if they do not focus on e-education (and not only on the use of its individual elements). E-education allows students to combine study and work. Sociological studies show that students are increasingly considered employment as a basis for their professional careers while at university ${ }^{9}$.

The foregoing trends in education and the modern labor market allows us to propose the formation of a theoretical framework for a sociological study of the potential of e-university education, which is based on two triads, namely, behavioral and individualizational, which manifests itself in all societies that indulge in an individualized culture (Fig. 1-2).

The first triad includes the interconnection and interdependence of the market for electronic educational services, the labor market and the social behavior of individuals and groups.

The second triad includes the interrelation of individualization of educational communications, the individualization of education through the consumption of electronic educational services, the individualization of employment through individual trajectories of search and work performance. At the same time, individualization of employment is especially relevant among freelancers.

${ }^{7}$ Каргаполов С. В., Каргаполова Е. В. Электронные средства коммуникации в социальных практиках современной молодежи (по материалам конкретного социологического исследования). Социологический альманах. Вып. 7. Минск : Беларуская навука, 2016. С. 275.

8 Барбер М., Доннелли К., Ризви С. Накануне схода лавины. Высшее образование и грядущая революция. Вопросы образования. 2013. № 3. С. 158.

9 Филоненко В. И., Скачкова Л. С., Филоненко Ю. В. Занятость студентов во время обучения в вузе. Социологические исследования. 2018. № 9. С. 135-140. 
The market of electronic educational services

Social behavior of

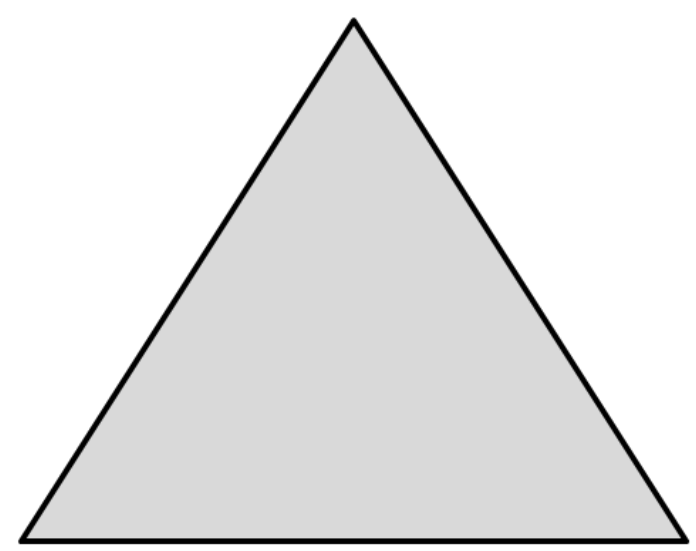

individuals and groups

Labor market

Fig. 1. Behavioral triad in e-university education

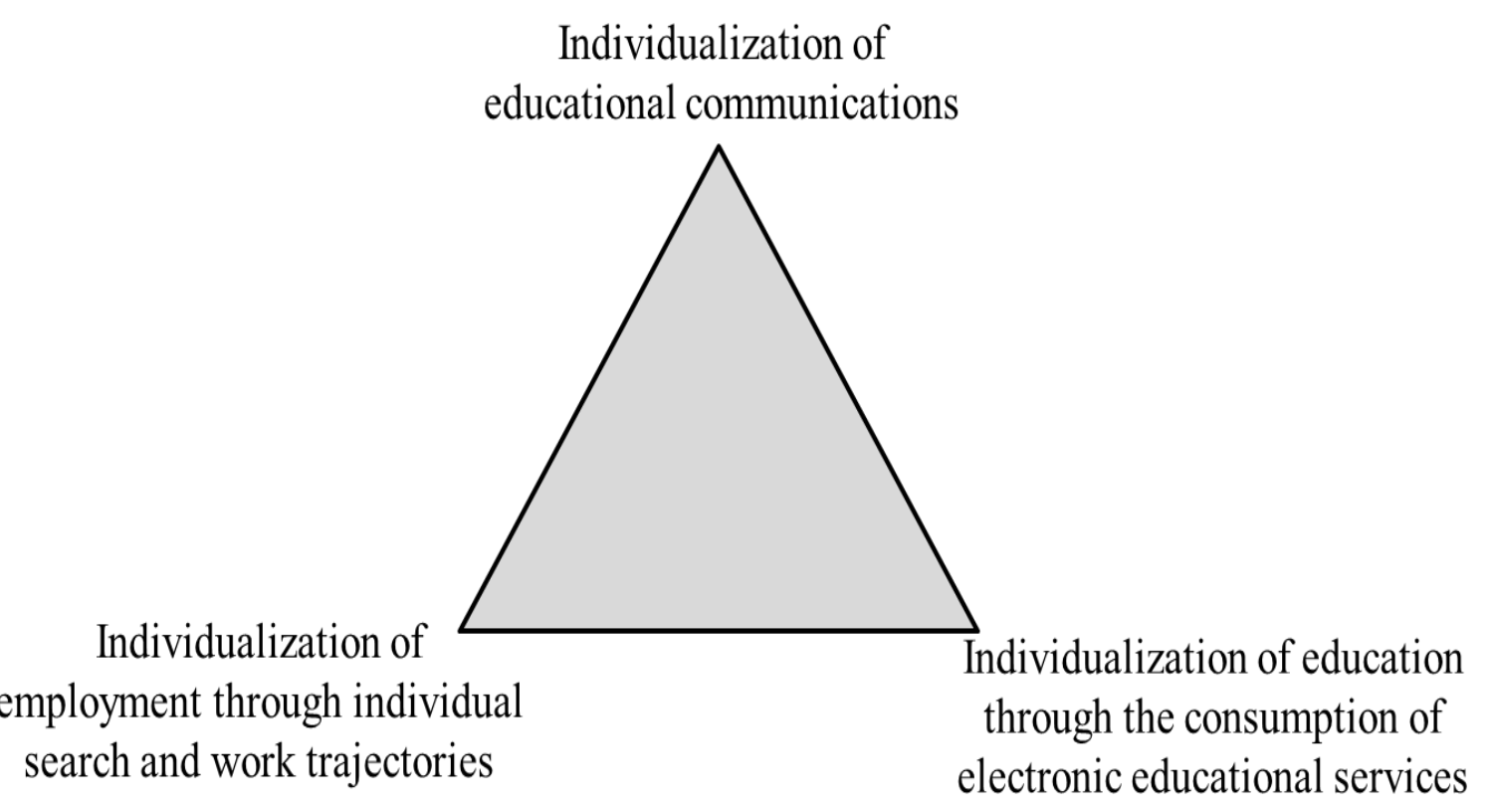

Fig 2. The triad of individualization in e-university education

Research methods. Referring to the analysis of empirical sociological research material that the authors conducted involving the employees of the Department of Applied Sociology and Social Communications of V. N. Karazin Kharkiv National University within 
the research theme "Problems of introducing the technologies of e-learning in Ukrainian Higher School" (from 10 to October 25, 2016 the survey conducted including 260 lecturers-experts from 42 universities concerning the problems of e-learning technologies implementing in higher education of Ukraine). Criteria for experts' selection: they work in higher educational institutions of Ukraine, use electronic learning technologies in their professional activities, use electronic learning technologies in higher educational institutions where an expert works.

For our purpose the opportunities of e-learning at universities can be divided into two groups: 1) market (commercial) and 2) non-market (reputational) ones.

\section{Commercial Appeal for Entry of Ukrainian Universities into the Market of E-Learning Services According to Expert Evaluations}

Among the performance indicators of a modern university, scientists lay emphasis on the demand for a specialist trained by a particular university in the labor market ${ }^{10}$.

As for e-learning, its demand depends on whether it is commercially successful or not. The commercialization of educational activities of universities governs this demand, makes us to provide educational services with the help of e-learning technologies, taking into account the commercial component. Expert views as for commercial success of elearning in Ukraine is divided: $46 \%$ respondents think it is possible, approximately $19 \%$ do not agree with it, and $35 \%$ couldn't pick a side at the time of sociological survey (fig. 3).

Social, status and demographic characteristics of experts do not influence such evaluations. They can also signify the underdevelopment of the market for e-learning services in Ukraine.

More than two third of experts $(68 \%)$ consider that the implementation of e-technologies in the educational process is a necessary condition to improve their competitive positions (fig. 4).

${ }^{10}$ Ильчук С. Б. Востребованность выпускника на рынке труда как индикатор эффективной деятельности современного вуза. Журнал соииологии и социальной антропологии. 2008. Т. 11. № 1. С. 191-200. 


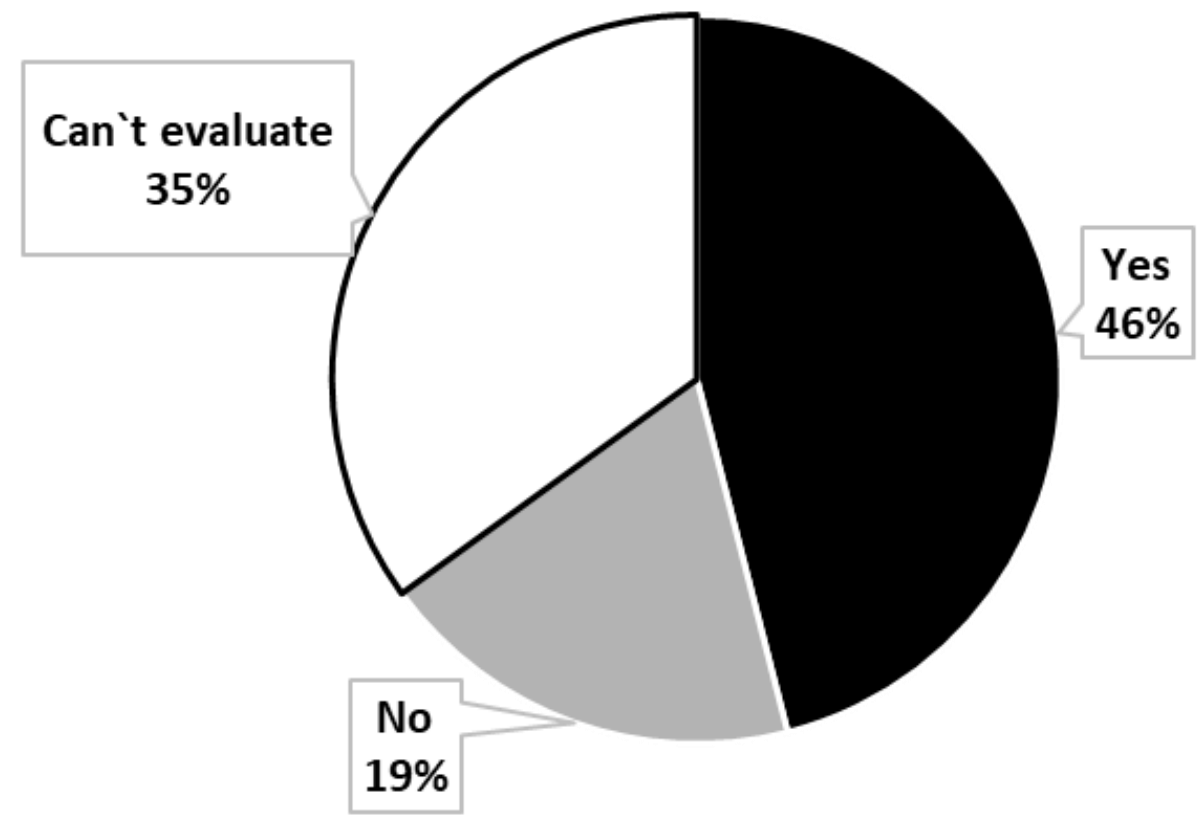

Fig. 3. Can e-learning at universities in Ukraine be commercially successful (\% for respondents; expert evaluation, $n=260$ )

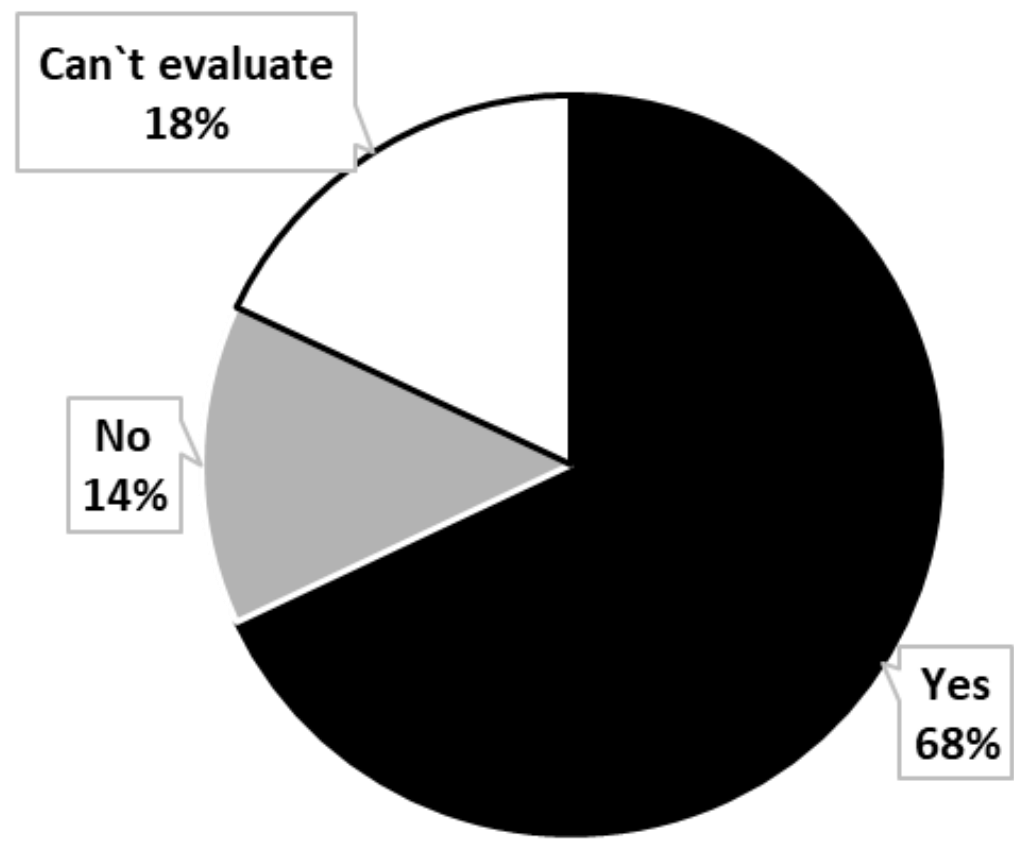

Fig. 4. Do you agree with the statement "Universities which do not develop e-learning technologies cannot compete in the market of learning service?" (\% for respondents; expert evaluation, $n=260$ ) 
Experience has shown that the benefit of learning services, including electronic ones, does not start immediately, it depends not only on the direct quality of the services received, but also on a number of parameters that the university practically cannot influence (such as the activity of the graduate when job hunting, his/her communication skills and labor market conditions).

Nowadays, the need for social technologies how to overcome the risks of e-education is being mainstreamed in Ukraine. Mostly, scientists are suggested to form students' critical thinking and develop their own views and ability to communicate effectively; come to creative solutions and anticipate situations. The vision of their role and place in the modern world in interdependence with others is also very important ${ }^{11}$. "The analysis of expert assessments indicates that alternative models of higher education presented in the form of a dichotomy "traditional education - e-learning" does not receive support from the lecturers as subjects of the educational process. The mixed model of higher education becomes attractive for them. This problem is the result of the selection of a traditional model and the introducing e-learning technologies in the system of higher education. Higher school functioning in the conditions of educational hybrids is a new reality of Ukrainian higher educational establishments"12. Researchers record an increase in the distance between the two main educational communities - students and lecturers ${ }^{13}$.

As part of the study the experts were asked to answer the open question: "In your opinion, which risks are possible for subjects of e-learning?". The most common answers of the expert are given below.

\section{Risks of switching to e-learning for students:}

- loss of quality of education, especially if there are no effective forms of control;

11 Трякіна О. О. Електронне навчання (e-learning): нові тенденції розвитку в процесі самоосвіти. Вісник Луганського нац. ун-ту імені Т. Г. Шевченка. Луганськ, 2011. № 5 (216). C. 25-34.

12 Хижняк Л. М., Хижняк К. В. Гібридизація у вищій освіті в умовах впровадження технологій електронного навчання. Соціальні технологї: актуальні проблеми теорії та практики. 2016. Вип. 72. С. 144.

13 Зборовский Г. Е. Можно ли быть вместе, находясь врозь: студенты и преподаватели в вузе. Социологические исследования. 2018. № 9. C. 49-58. DOI: $10.31857 / \mathrm{S} 013216250001958-6$. 
- loss of opportunities to socialize in a student group due to constant interpersonal contacts between students;

- absence of emotional contact with the tutor;

- loss of opportunities to acquire experience in team work and ability to build relationships in real time and space;

- at the initial stage of the e-learning development at university, it is possible to "collect" certificates without proper quality;

- "fragmentarity" of knowledge gained through the e-learning technology;

- students can not complete their studies without self-discipline.

Risks of switching to e-learning for teachers.

- difficulties to master new teaching methods and technologies;

- growth of competitiveness among educators;

- increase in the intensity of teaching work and additional workload;

- reduction of the need for educators and as a consequence - the risk to lose the job (even for highly qualified teachers);

- absence of emotional contact with students.

Risks for switching to e-learning for universities:

- reduction in educational process effectiveness and quality of education;

- inconsistency of teacher training with requirements for e-teaching;

- admission risks;

- increased costs (at least at the initial stage) for educational process material and technical support;

- risk to lose some effective teachers who won't be able to adjust for new requirements;

- financial and reputational loses (at least at the initial stage) as a result of lack of experience in e-learning;

- reduction in educational process effectiveness and quality of education because of conventional attitude of both students and teachers to the educational process;

- problems with qualitative assessment of educational outcome;

- loss (or reduction) of effectiveness of pedagogic function of universities. 


\section{Labor market demand forecast for specialists who got e-education at universities, according to expert evaluation}

To set down in plat the development of e-learning service market, we suggested the experts to assess its immediate prospects, namely to answer the question: "In your opinion, how will the demand for specialists who have received e-education at university change in the labor market in Ukraine in the next 2-3 years?». Again the opinions of the experts were different. Here are the opinions of groups of experts for specialists who have received e-education at university:

1) Experts who believe that the demand will increase $-19 \%$.

2) Experts who believe that the demand will not change $-41 \%$.

3) Experts who believe that the demand will decrease $-5 \%$.

4) Experts who cannot pick a side - $35 \%$ (fig. 5).

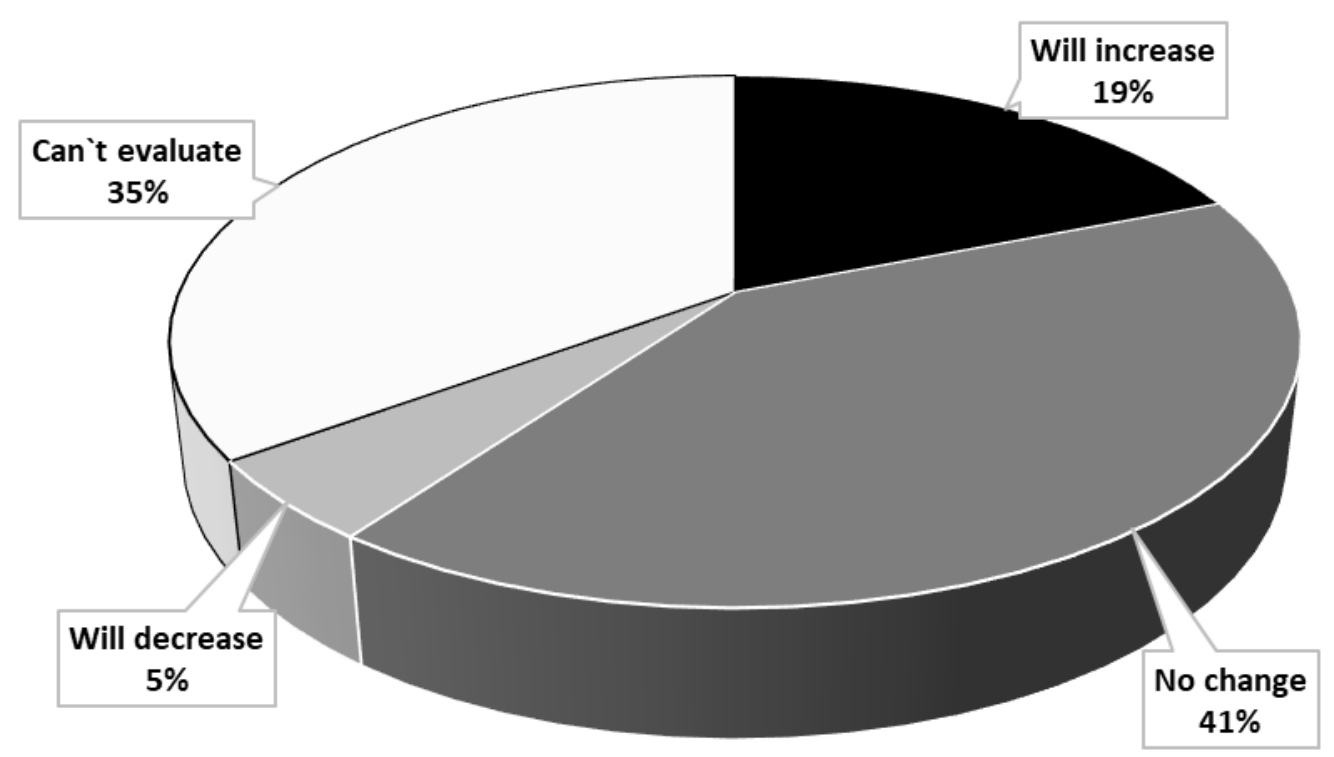

Fig. 5. How will the demand for specialists who have received eeducation at university change in the labor market in Ukraine in the next 2-3 years? (\% for respondents; expert evaluation, $n=260$ )

A statistically significant correlation between the experts' estimations concerning the demand for specialists with electronic higher education depending on the specialization of the respondents is given in the table 1 (Cramer's coefficient is equal to 0.235 at $1 \%$ level of 
significance). Experts in the field of natural sciences are more optimistic (table 1).

\section{Table 1}

\section{Experts' Estimations Concerning the Demand for Specialists with Electronic Higher Education Depending on the Specialization}

(\% for respondents; $n=260$ )

\begin{tabular}{|l|c|c|c|c|}
\hline \multirow{2}{*}{ Expert groups } & \multicolumn{3}{|c|}{ Specialization of the experts } \\
\cline { 2 - 5 } & $\begin{array}{c}\text { Engineering } \\
\text { sciences }\end{array}$ & $\begin{array}{c}\text { Natural } \\
\text { sciences }\end{array}$ & $\begin{array}{c}\text { Social and } \\
\text { Humanity } \\
\text { sciences }\end{array}$ & Economics \\
\hline $\begin{array}{l}\text { Experts who } \\
\text { believe that the } \\
\text { demand will } \\
\text { increase }\end{array}$ & 13 & 39 & 16 & 17 \\
\hline $\begin{array}{l}\text { Experts who } \\
\text { believe that the } \\
\text { demand will not } \\
\text { change }\end{array}$ & 36 & 31 & 49 & 28 \\
\hline $\begin{array}{l}\text { Experts who } \\
\text { believe that the } \\
\text { demand will } \\
\text { decrease }\end{array}$ & $\mathbf{2 1}$ & $\mathbf{8}$ & $\mathbf{1}$ & $\mathbf{5}$ \\
\hline $\begin{array}{l}\text { Experts who cannot } \\
\text { pick a side }\end{array}$ & $\mathbf{3 1}$ & $\mathbf{2 2}$ & $\mathbf{3 4}$ & $\mathbf{5 0}$ \\
\hline
\end{tabular}

Electronic educational services fit organically into the digital economy, which requires special competencies from staff and increases risks in education and in the labor market. Therefore, it is important that students and lecturers adapt to the uncertainty of the university environment that arose during the transition to a digital economy ${ }^{14}$. One of the effective ways of such an adaptation, as studies show, is the ability of students to find employment during the period of study at the university. Ability to employment is considered by scholars as a

14 Мозговая А. В. Адаптация молодёжи к неопределённости университетской среды в период модернизации института высшего образования. Социологическая наука и соииальная практика. 2018. № 2. С. 110-125. DOI: https://doi.org/ 10.19181/snsp.2018.6.2.5860. 
competence that provides employment and career prospects of the individual, competitiveness in the labor market $^{15}$.

\section{Target audience of e-learning at universities in Ukraine according to experts' evaluations}

E-learning is a way to solve the problem of non-uniform access to educational resources with the help of modern e-learning tools. Scientists point out a lot of advantages of e-learning, including independence from geographic location; time saving; efficiency and psychological comfort. In this case, e-learning technologies should be developed and implemented taking into account the requirements of consumers of e-learning services.

To forecast the development of e-learning service market and the labor market of the relevant professionals, it is important to identify target groups which are interested in e-learning. An expert survey showed that there are three groups which are the leaders of the target audience in the e-learning, namely: individuals who want to combine learning with production activities (67\%); people who are geographically isolated from their educational resources $(58 \%)$; people with physical, physiological or emotional problems (55\%). Experts expect a slight increase in the demand for e-learning services for those who want to change their profession or improve their skills (43\%) and those who already have substantial knowledge and want to take the educational program over a short period of time (39\%), or wish to master special educational programs consisting of courses provided by different educational establishments (37\%). Thus, according to experts, academic mobility cannot be the dominant factor in increasing the demand for e-learning services (fig. 6).

According to experts, the least demand for e-learning services should be expected from those who are engaged in arts, sports and do not want to interrupt education (9\%) and those who have not completed university education in their youth $(8 \%)$. In our opinion, this situation is due to the fact that the prestige of university education in contemporary Ukraine is not high, that is why people of the middle age and elderly people who do not have it, are not motivated to continue their education.

15 Мозговая А. В., Яишников А. Ю. Способность к трудоустройству как ресурс профессиональной адаптации личности. Вестник Института соџиологии. 2018. № 26. С. 143-157. 


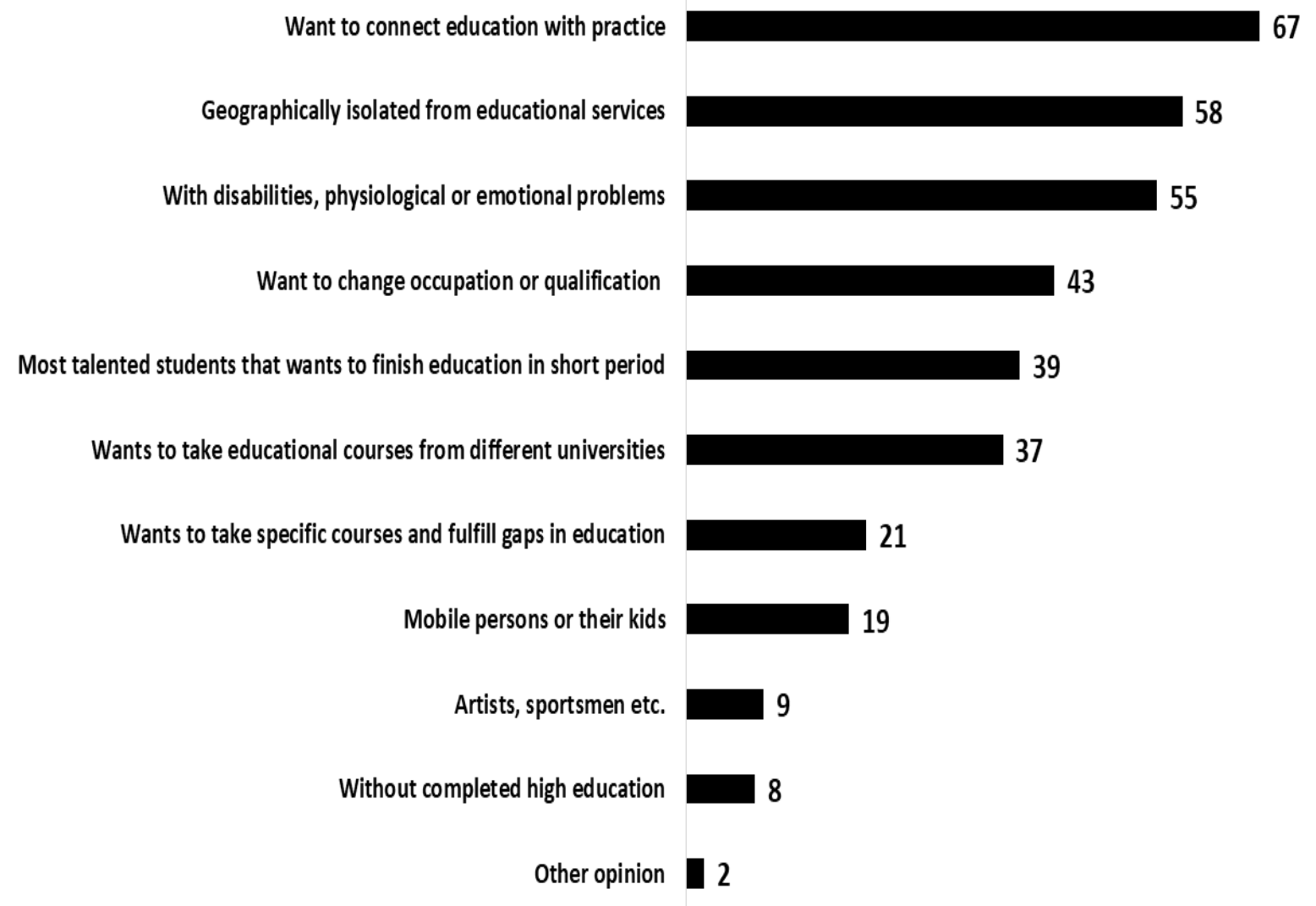

Fig. 6. Target audience for e-learning at universities in Ukraine (expert evaluation in \%, $n=260$ )

Universities that seek to be successful and meet the challenges of the contemporaneity should research not only the demand for e-learning services, but also create this demand with the help of appropriate communication technologies (advertising and PR), identify the categories of people who, in their social status, educational needs and professional interests require new forms of learning services, which include first of all e-learning.

Prisonmates or ex-prisonmates who serve or have served the time in jail can be a bright example of such specific target audience. This is a specific group, which include those who have had such experience and need social reintegration after dispensation from imprisonment. Educational opportunities play a prominent role for reintegrating a person into society in modern conditions.

A lot of ex-prisoners are actively searching for work, planning to take up individual labour activity, create their own enterprise, get education, but those who are passive stand cannot be disregarded either, as they are at risk population group. These individuals especially need attention from both the 
employees of rehabilitation centers and the state institutions that take care of this contingent, including employment services, where they go to seek employment. The employment services could become the customers of corresponding e-learning programs for such individuals and implement educational programs together with different educational establishments of different levels. In this case, e-learning is relevant (on conditions that target audience is computerate, which can also be the task of rehabilitation centers and employment services).

Let us sum up. First, people released from places of detention may be considered as potential target audience for e-learning; secondly, it is expedient for educational institutions of different levels to develop special educational programs for this group which would meet the needs, interests, target orientation and values of this rather heterogeneous group. The obtained results show that among those who were released from prison there are a lot of people who have active plans, primarily related to economic activity (job hunting, setting up their own business, obtaining education). Therefore, in our opinion, it is very important to develop a set of actions to prevent the negative attitude towards such women, especially on the part of employers and educators, overcome stereotypes and prejudices, etc., which will facilitate successful professional reintegration of this contingent into the community, and reduce backslide of female crime. Finally, a society is interested in social reintegration of its citizens, and for this purpose it should take care of their education. E-learning, due to its characteristics, becomes a factor that allows the representatives of this group of women to raise (renew) their social status.

Foreign students may also be potential target audiences of e-learning in Ukrainian universities. However, in this case the issues of organization of effective intercultural communication by the university become actual $^{16}$. To substantiate this conclusion, we should add the following. We share opinion that at present, socio-cultural modernization plays a much more important role in the renovation of modern university education strategy than strategies based on economic principles"17.

16 Бакіров В. С., Ушакова Н. І., Хижняк Л. М. Міжкультурна комунікація в університеті: історичний досвід і виклики сучасності. Вісник Харківського національного університету імені В. Н. Каразіна. Серія «Соціологічні дослідження сучасного суспільства: методологія, теорія, методи». 2017. Вип. 39. С. 286-293.

17 Богданова М. В. Этос университета: социологическая операционализация потенциала «неписаных правил». Социологический журнал. 2017. № 2. С. 153. 
The labor market enter students, which for one reason or another leave universities. For many of them, e-learning services can serve as the instrument for the professional growth and acquisition of the educational status of a person with higher education ${ }^{18}$.

\section{CONCLUSIONS}

The concept of education which is suggested by B. Clark and which we totally agree with, is based on the idea of support for university changes ${ }^{19}$. Let us add that these changes come in contact with commercial and non-commercial elements of education. It fully relates to the opportunities of e-learning in modern Ukraine.

The market (commercial) potential of e-education determines the commercial attractiveness (success) of e-education, which is evidenced, first of all, by the demand of specialists who have received e-education in the labor market. The nonmarket (reputation) potential of e-education determines the image characteristics of the university providing e-learning services.

The analysis of the ratio of commercial and non-commercial attractiveness for the universities of Ukraine to enter the market of e-learning services shows: the reputational advantages of the Ukrainian universities for entry in the e-learning service market, according to experts, now dominate a bit commercial advantages.

The potential target audience of e-learning in Ukraine is rather heterogeneous. Scientists distinguish the corporate and educational sectors and consumers of individual e-learning. Work with different groups of consumers of e-learning services involves the development of relevant educational programs by each specific university.

We have proposed to consider the ratio of the market of electronic educational services and the labor market in terms of the individualization of modern culture as a triad that includes the individualization of social communications (including educational), the individualization of education through the consumption of electronic educational services and the individualization of employment.

${ }^{18}$ Горбунова Е. В. Выбытия студентов из вузов: исследования в России и США. Bопросы образования. 2018. № 1. С. 110-131.

${ }^{19}$ Кларк Б. Р. Поддержание изменений в университетах. Преемственность кейсстади и концепций; пер. с англ. М. : НИУ ВШЭ, 2011. 312 с. 
E-education can give universities reputational and economic (financial, commercial) benefits if they have a special intellectual resource - a motivational one. It is, on the one hand, about the motivation of students to receive high-quality electronic educational services, and on the other hand, the motivation and willingness of lecturers to provide such a service as necessary. A separate factor is the readiness of universities for e-education, which requires separate consideration.

Research of employers opinions regarding the professional and personal qualities of graduates, as well as employers' preferences in the process of recruiting young professionals appear more often ${ }^{20}$. At a later stage it is expedient to expand the circle of experts on the development of e-learning service market and labor market at the expense of employers and representatives of potential target audience of these markets.

\section{SUMMARY}

The article is devoted to the disclosure of the potential of e-university education in Ukraine as assessed by teachers. The author has conditionally divided the potential of e-university education into two groups: 1) market (commercial) and 2) non-market (reputation). The theoretical framework of sociological study of the potential of university education is proposed, which is based on two triads, which include behavioral and individualized characteristics. The conclusions are based on the materials of an empirical sociological study conducted with the participation of the author. The article outlines the commercial attractiveness for Ukrainian universities to enter the market of electronic educational services in experts' assessments. The demand forecast on the labor market for specialists who have received electronic higher education in experts' assessments has been estimated. The potential target audience of e-university education in Ukraine in experts' assessments has been defined.

\section{REFERENCES}

1. Айдрус И. А., Горшкова Л. Ю. Особенности развития мирового рынка образовательных услуг на современном этапе. М. : Рос. ун-т дружбы народов, 2015. 320 с.

${ }^{20}$ Месхи Б. Ч., Филоненко В. И., Скачкова Л. С., Филоненко Ю. В. Проблемы и парадоксы трудоустройства студенческой молодежи в оценках работодателей (по итогам социологического исследования). Власть. 2017. № 10. С. 83-90. 
2. Бакіров В. С., Ушакова Н. І., Хижняк Л. М. Міжкультурна комунікація в університеті: історичний досвід і виклики сучасності. Вісник Харківського національного університету імені В. Н. Каразіна. Серія "Сочіологічні дослідження сучасного суспільства: методологія, теорія, методи». 2017. Вип. 39. С. 286-293.

3. Барбер М., Доннелли К., Ризви С. Накануне схода лавины. Высшее образование и грядущая революция. Вопросы образования. 2013. № 3. C. 152-236.

4. Богданова М. В. Этос университета: социологическая операционализация потенциала «неписаных правил». Социологический журнал. 2017. № 2. С. 153-170.

5. Горбунова Е. В. Выбытия студентов из вузов: исследования в России и США. Bonросы образования. 2018. № 1. С. 110-131.

6. Жукоцкая А. В., Васильев И. А. Мотивационные позиции студенческой молодёжи на образовательном поле. Вестник Института социологии. 2018. № 25. С. 78-99.

7. Зборовский Г. Е. Можно ли быть вместе, находясь врозь: студенты и преподаватели в вузе. Соииологические исследования. 2018. № 9. С. 49-58.

8. Ильчук С. Б. Востребованность выпускника на рынке труда как индикатор эффективной деятельности современного вуза. Журнал соџиологии и социильной антропологии. 2008. Т. 11. № 1. C. 191-200.

9. Каргаполов С. В., Каргаполова Е. В. Электронные средства коммуникации в социальных практиках современной молодежи (по материалам конкретного социологического исследования). Социологический альманах. Вып. 7. Минск : Беларуская навука, 2016. C. 271-276.

10. Кемп. Нил. Новые тенденции международного рынка образования. Международное высшее образование. 2016. № 85. C. 19-21. https://ihe.hse.ru/article/view/2941/2678 (accessed 10.05/2019).

11. Кларк Б. Р. Поддержание изменений в университетах. Преемственность кейс-стади и концепций. М. : НИУ ВШЭ, 2011. 312 с.

12. Месхи Б. Ч., Филоненко В. И., Скачкова Л. С., Филоненко Ю. В. Проблемы и парадоксы трудоустройства студенческой молодежи в оценках работодателей (по итогам социологического исследования). Власть. 2017. № 10. С. 83-90. 
13. Мозговая А. В. Адаптация молодёжи к неопределённости университетской среды в период модернизации института высшего образования. Социологическая наука и соичиальная практика. 2018. № 2. С. 110-125.

14. Мозговая А. В., Яишников А. Ю. Способность к трудоустройству как ресурс профессиональной адаптации личности. Вестник Института соичологии. 2018. № 26. С. 143-157.

15. Немировский В. Г., Немировская А. В. Социальная конкурентоспособность: шансы на успех у молодежи и взрослых. Социологический журнал. 2018. № 2. 135-149.

16. Попова Е. С. Горизонтальная профессиональная мобильность, профессиональное образование и рынок труда в России в динамике лет. Социологическая наука и сочииальная практика. 2018. № 1 . С. 53-70.

17. Трякіна О. О. Електронне навчання (e-learning): нові тенденції розвитку в процесі самоосвіти. Вісник Луганського нац. ун-ту імені Т. Г. Шевченка. Луганськ, 2011. № 5 (216). С. 25-34.

18. Филоненко В. И., Скачкова Л. С., Филоненко Ю. В. Занятость студентов во время обучения в вузе. Социологические исследования. 2018. № 9. С. 135-140.

19. Хижняк Л. М., Хижняк К. В. Гібридизація у вищій освіті в умовах впровадження технологій електронного навчання. Соціальні технології: актуальні проблеми теорії та практики. 2016. Вип. 72. C. 137-144.

20. Шэтток Майкл. Повышение информированности участников рынка: Рамочная программа улучшения качества преподавания (TEF) в британском высшем образовании. Международное высшее образование. 2018. № 92. C. 27-29. https://ihe.hse.ru/article/view/ 7564/8386 (accessed 10.05/2019).

\section{Information about the author: Khyzhniak L. M.}

Doctor of Sociological Sciences, Professor, Professor of the Applied Sociology and Social Communication Department, School of Sociology,

V. N. Karazin Kharkiv National University 4, maidan Svobody, Kharkiv, 61045, Ukraine 


\section{THE KNOWLEDGE ECONOMY AS A PARADIGM OF THE ESTABLISHMENT AND DEVELOPMENT OF POST-INDUSTRIAL SOCIETY}

\section{Matiuk T. V.}

\section{INTRODUCTION}

The current state and prospects of development of the national economy are the result of the interaction of two objective processes. On the one hand, it is the influence on the trajectory, quality and changes rate in a society of the whole set of national specific traits of political, cultural, social, economic and institutional nature, which determine and will determine in the future peculiarities of the socio-economic evolution of the country. On the other hand, it is the dependence of nation-states on the tendencies of the development of the world economy, whose significant influence on the quantitative and qualitative indices of the functioning of the countries of the world has been greatly enhanced by the expansion of globalization processes.

The Ukrainian economy is also under the significant influence of interrelated processes. On the one hand, the negative "legacy" of the former administrative-command model of development, the complexity of market reforming of the economy, certain missteps of the economic policy of the state, etc., determines the contradictory tendencies of modern relations in the country. On the other hand, in the modern context, each country has a clear set of guidelines for further development taking into account the advanced trends of world evolution, which are associated with the transition of leading countries to post-industrial society. Therefore, an alternative to the further motion of countries is a combination of their sustainable traditions with the best that has emerged in world practice. In other words, it involves the need for development to meet the needs of modern post-industrial civilization.

\section{Theoretical frameworks of the study of the knowledge economy}

One of the key characteristics of global changes today is the development of the knowledge-based economy. Even though education, inventions, knowledge accumulation have been important features of 
progress throughout world history but power and wealth have been the main sources of authority. At the modern stage, this balance is broken and, as A. Toffler rightly says, there are power metamorphoses which cause "strong dependence of power and wealth on knowledge".

The term "the knowledge economy" occurs more frequent in foreign and domestic research and is used to define the type of economy where knowledge plays a decisive role and knowledge production is a source of growth. Today, the knowledge economy in the broadest sense includes four main spheres: 1) R\&D and innovation; 2) education and training which contribute to the formation of human capital assets; 3) computer information technology (CIT); 4) high-quality production.

Although each of these spheres preserves their relative autonomy, their interrelation is clear. In fact, there is an increasing convergence of three different spheres of social activity, since diffusion of information technologies into other spheres is impossible without the appropriate level of professional training of developers and minimal information literacy of users. Besides, to open up new applied opportunities for CIT, it is necessary to have new scientific knowledge and mechanisms to transform the knowledge into commercial products - goods and services. For this very reason, it is essential to refer to the knowledge economy as the most important for the development and to information society as a whole.

Today, economic theory doesn't have a well-established concept of the category "the knowledge economy". J. Schumpeter, F. Hayek, and F. Machlup laid the foundation of the knowledge economy. Thus, F. Machlup $(1962)^{2}$ considered the knowledge economy as the economic sector where knowledge plays a decisive role and knowledge production is a source of growth; moreover, he also highlighted the active growth of the relevant economic sector. According to calculations of the scientist, in 1958, the knowledge economy sector was $29 \%$ of U.S. gross domestic product. F. Machlup attributed the following five types of activities to the relevant sector: education, research and developments, mass media (radio, TV broadcast, telecommunication and others), IT, information

1 Тоффлер Э. Метаморфозы власти: Знание, богатство и сила на пороге XXI века / [Пер. с англ. науч. ред., предисл. П.С.Гуревича]. Москва: ООО «Издательство АСТ», 2002. 670 с.

2 Machlup F. The production and distribution of knowledge in the United States. Princeton: Princeton University Press, 1962. 416 p. 
services. However, due to the expansion of the so-called "knowledge sector" in the context of the greatest economic growth achieved through research and innovation, the term "knowledge economy" has gained a new meaning. Thus, "the knowledge economy" or "knowledge-based economy" is considered as the type of economy where knowledge plays a pivotal role. That kind of the term's meaning was popularized by P. Drucker. In his book "The Age of Discontinuity: Guidelines to our Changing Society" (1968 p.) $)^{3}$, the author considered using knowledge for the production of economic goods. He came to grips with the issue of what resource is central in the modern economy. P. Drucker argued that physical, financial and managerial resources are not the decisive factors of production. Based on the above, he defined the knowledge economy as a special type of economy where knowledge plays a decisive role, and their production became a source of economic growth and competitiveness. Since the mid-1990s, the concept of the knowledge economy has been actively developed by many economists from around the world and has been supported by such reputable organizations as the United Nations, the Organisation for Economic Co-operation and Development (OECD), the World Bank and United Nations Educational, Scientific and Cultural Organization (UNESCO), as well as by the socio-political elite of almost all developed countries and some developing countries. In the UN experts view, the knowledge economy is economy where knowledge is formed, spread and used for providing economic growth and international competitiveness of the country. At the same time, knowledge enriches all industries, all sectors and all participants in economic processes. In the broadest sense, the concept of the knowledge-based economy is economy where information and knowledge based on it occupy a top-priority position. The basis of that kind of economy is the creation, dissemination and use of knowledge to ensure its sustainable development and competitiveness. The knowledge economy is also a type of economy where the very generation and use of knowledge plays a dominant role in the creation of prosperity; however, human capital becomes the center of economic activity of economic entities. In the late nineties, the concept "the knowledge economy" got the most widespread use.

\footnotetext{
${ }^{3}$ R. L Katz. New York : Praeger, 1988. 168 p.
} 
The development of the knowledge economy and determination of the knowledge influence on the economic activity of particular business entities takes place within the study of human capital structure. Knowledge, as an integral part of human capital, is considered in modern economic science in the context of such research lime as human capital theory. The creation of the theory can be interpreted as one of the most remarkable events.

Modern society is the knowledge society, and for this reason, the more recent attention has been paid to the knowledge-based economy as a key to the establishment and development of post-industrial society, the development of economic relations and the improvement of the quality of living standards. To ensure the development under the conditions when the information and the knowledge obtained on its basis become one of the main objects of management, there is a challenge to develop and apply new management methods that will turn the knowledge into a unique product and the main strategic resource for the development of all economic entities.

The knowledge economy is characterised not only by the development of high technologies but, first of all, by effective mechanism of knowledge production, that is appropriate education system, communication system, fundamental and applied science, patent system and awareness-raising activities on the development of that kind of economy, ensuring high living standards of the population for human potential development, because it is the very factor contributes to the establishment of a post-industrial society at the present stage of economic transformation.

Modern education has to meet the main parameters of the emerging post-industrial civilization. In the book "Future shock", A. Toffler marks that a new strategy is a re-orientation of the education system that will guarantee "soft landing in the future" for the new generation". The modern approach needs the issue regarding the new human image as an education result.

Today, the world needs not just a person who knows but who understands. Education in the modern world is considered not as the final product of one of the stages of human life but as a constant and dynamic process. In the past, education was limited by a well-defined and quite

${ }^{4}$ Тоффлер А. Футурошок - СПб. : Лань, 1997. 464 с. 
short period of working life after which a person gave up the education system and rarely came around to study again. In the context of current fast time, the rapid obsolescence of knowledge necessitates their constant updating and periodic improvement of educational background. Since birth, learning continues actually throughout human life.

In going from the traditional to a new level, a man finds out and keeps the ability to establish cause-effect relations, to get to the root of socio-economic processes, phenomena; to find original and at the same time simple fix; to synthesize available knowledge in a new system. As such, it is necessary to put your problems into the rank of tasks which are easy to fix, that is, to make your life and business trouble-free.

A man who thinks is a product of traditional education systems, and thinking man (that is a wise man) is a product of ultramodern education system. A smart person always finds a way out of any complicated situation, and the main target of ultramodern education systems is to bring up a wise person who can predict and prevent the origin of challenges. Traditional and ultramodern education systems laconically complement each other. The old education system provides general knowledge, and new one teaches how to use gained knowledge and skills as effectively as possible for solving particular problems.

Thus, the efficiency of modern physical output and scientific and technological progress are directly dependent on, among other factors, the general development of knowledge and skills of workers. Within this context, the education system, acting as the key link in the process of reproduction of the total workforce, plays a growing role in the social, economic and scientific and technical development of the country.

At the same time, the modern rapid development of the information society outstrips the possibilities of meeting the demand for professional training. Education establishments are now training students for work that is not available yet using day-old technology. Thus, according to international experts, 10 most sought after professions in 2010 did not exist in 2004. As the amount of new scientific and technical information doubles every 2 years, for students studying 4 years, it means that half of what they study will become obsolete by the end of the third year of study.

It is clear that in the post-industrial era, dynamics and transition rates of the economy to the knowledge economy mainly depend on the efficiency of using the results of human creative activity. For this reason, one of the main challenges which need constant attention is the creation of 
an effective system of production, protection, reproduction and use of the intellectual potential that requires corresponding changes in the education system. The very education as the system of formation of the intellectual capital of the people and as one of the main spheres of innovation production creates basic conditions for rapid development of an economy based on achievements of scientific and technological progress.

As the knowledge economy is considered to be the most important condition for socio-economic development, its diagnostics through specially developed knowledge economy index becomes an essential component for studying the evolution of economic and education systems. Methodology for index calculation is a reproduction of institutional development concepts, which show that the transition of the countries' economy to the post-industrial stage of development is impossible without the institutional changes and high quality of education that causes the changes.

Table 1

EBRD 2018 Knowledge Economy Index - performance by economy

\begin{tabular}{|c|c|c|c|c|c|c|}
\hline Economy & 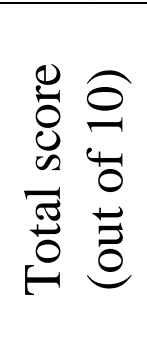 & 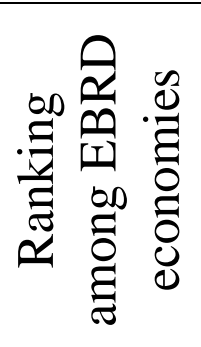 & 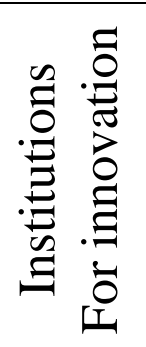 & 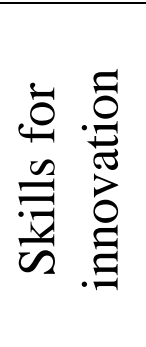 & 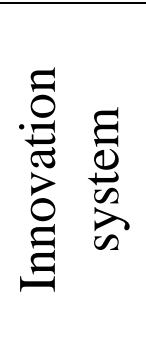 & 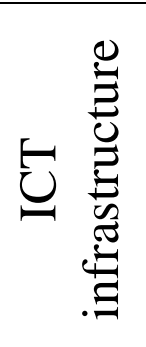 \\
\hline Estonia & 6.82 & 1 & 8.01 & 6.70 & 4.58 & 7.99 \\
\hline Poland & 5.63 & 6 & 6.80 & 6.31 & 3.82 & 5.58 \\
\hline Hungary & 5.33 & 9 & 6.55 & 5.82 & 3.49 & 5.47 \\
\hline Romania & 5.01 & 15 & 6.02 & 4.94 & 3.41 & 5.68 \\
\hline Turkey & 4.60 & 19 & 4.87 & 4.81 & 3.82 & 4.90 \\
\hline Belarus & 5.21 & 11 & 5.50 & 6.05 & 3.27 & 6.01 \\
\hline Ukraine & 4.29 & 27 & 4.33 & 5.44 & 2.84 & 4.56 \\
\hline
\end{tabular}

Source $^{5}$

In the above rating, Ukraine takes $27^{\text {th }}$ place among other 37 world countries. Therefore, the approximation to the knowledge economy as a

5 Індекс економіки знань: веб -сайт. URL: file://C:/Users/User/Downloads/ebrdknowledge-economy-index.pdf 
component of postindustrial civilization through the direct and immediate way is linked to the formation of qualitative characteristics of social consciousness as one of the main factors in the formation of an effective institutional environment that contribute to innovative development.

Thus, indices data show that Ukraine takes a relevant position, first of all, due to the low index of the Innovation system, which is 2.84 .

In this context, it is essential to consider the level of economic, political and civic culture of Ukrainians, which is largely shaped by education. The latter establishes knowledge about the patterns of society's development in the unity of its economic and political spheres, changes people's visions of how to achieve better living conditions and their self-development. As a consequence, education changes people's concept of what government should be and what policy it should pursue to promote development.

Effective democracy in any country is based on active citizens. However, "uneducated society cannot effectively exercise collective selfdetermination. In order to have a strong democratic public position in relation to any social problem, people must comprehend the relevant concepts, principles, policy, procedures, ethical standards and certificates" $"$.

The lack of comprehension of interconnection between education and democracy and public activity in the consciousness of many Ukrainians, and especially young people, that causes passivity of the youth in forming fundamentals of extending rights and opportunities as a necessary component of the development. Only $1.5 \%$ of young Ukrainians work in public organisations and unions while in countries like Austria, Denmark, Belgium, Finland, Sweden, this proportion covers about $25 \%$ of young people ${ }^{7}$.

In general, the execution of functions by the economy of Ukraine doesn't meet the requirements of the postindustrial stage of human evolution fully. The relatively high level of the population literacy is not

${ }^{6}$ Демократизация глобальной экономики. Роль гражданского общества. Доклад центра изучения глобализации и регионализации университета г. Варвик: пер. на рус. яз. Л. Проскуряковой, 2003. 128 с. URL: http://warwick.ac.uk/fac/csgr/projects/ russianreport.pdf.

7 Українське суспільство 1992-2012. Стан та динаміка змін. Соціологічний моніто-ринг / [За ред. В. Ворони, М. Шульги]. Київ: Інститут соціології НАН України, $2012.348 \mathrm{c}$. 
characterised by an adequate quality of economic and human development and does not stimulate innovation. That sort of situation retards the rate of positive changes in the society and requires the relevant reforming in the aspect of conformity in requirements of the knowledge economy.

\section{Peculiarities of the development of postindustrial society under modern conditions}

Efforts of the founders of the theory of post-industrial society focused on identifying the characteristics of a new society. Research of D. Bell, H. Kahn, R. Dahrendorf led to careful thought of fundamentally different kind of society. Researchers consider the basis of the changes in enhancing the role of science. In their view, the potential for the development of that sort of society is determined by the scale of information and knowledge it possesses.

D. Bell, clearing up the novelty of modern sources of economic growth, recalled that land, capital and labour had been considered as the main factors of production for the industrial era for a long time. W. Sombart and J. Schumpeter enhanced the triad with such important concepts as "entrepreneurship" and "business initiative". However, D. Bell noted that "when knowledge in its systematic form is involved in the practical processing of resources (in the form of the invention or organizational improvement), one can say that the very knowledge, not labour, is the source of value" "With the reduction of working time and the role of manufacturing worker, it becomes clear that the knowledge and methods of its practical use replace labour as a source of added value. In this sense, labour and capital were central variables in industrial society, and information and knowledge became decisive variables in post-industrial society"

P. Krugman marks that "property is no longer the determining basis of elite status. Multibillionaires earn most of their income in the form of remuneration for their work",

8 Белл Д. Грядущее Постиндустриальное общество: опыт социального прогнозиро-вания / Перевод с английского Иноземцев В. Л. Изд. 2-ое, испр. и доп. Москва: Academia, 2004. 788 с.; Гальчинський А. С. Економічна методологія. Логіка становлення. Київ: «АДЕФ - Україна», 2010. 572 с.

${ }^{9}$ Krugman P. R The Conscience of a Liberal. W.W. Norton \& Co., 2007. 352 p. 
Thus, if land ownership, buildings, factories, machines, production means were the main physical element for industrial society, intangible substance became the basis of ownership under passing to postindustrial society ${ }^{10}$.

The situation in the new economy is that instead of land pressure, investment and capital, there is an excess of cash capital and production capacity. The most popular and desirable resources are a man and his intellect, whose properties significantly differ from traditional means of production. At the same time, the structure of socio-economic relations is changing as a new form - intellectual property, and a new dominant social group - the owners of knowledge appear to replace ownership of the means of production and land ownership". A. Toffler notes that "the most significant form of ownership is now imponderable. It is supersymbolic. It is knowledge. It can be simultaneously used by many people to create welfare and to produce new knowledge"12.

Spiritual ownership is fundamentally different from private one because it can develop only as an individual-personal and, at the same time, as public ownership. Its extended reproduction is mainly not on a commercial basis. It is directly related to the development of personal wealth and the accumulation of the spiritual (intellectual) potential of the whole society, and indirectly - to the accumulation of capital ${ }^{13}$.

Indeed, one of the main features of the new economy is the transition from the domination of material goods production (industrial economy) and the rapid development of the service sector (post-industrial economy) to the emergence of multifunctional information technologies, which in economic terms made it possible to intensify the processes of development of post-industrial economy significantly, in technical terms - to minimize the time of information transfer to anywhere in the country, and in social terms - to strengthen the role of the human factor and create a significant basis for the establishment of a mixed society. However, in the era of the new economy, the main strategic resource of production -

10 Брежнєва-Срмоленко О. В. Інтелектуальна складова в структурі елементів нової економіки. Актуальні проблеми економіки. 2010. № 3.

${ }^{11}$ Там само.

12 Тоффлер О. Метаморфозы власти: знание, багатство и сила на пороге XXI века / Пер. с англ. Москва: Аспект Пресс, 2004. 400 с.

13 Гальчинський А. С. Економічна методологія. Логіка становлення. Київ: «АДЕФ Україна», 2010. 572 с. 
both tangible and non-tangible one - is a man and his intelligence and skills but not knowledge, service or information. After all, human intelligence is a "productive force of a global scale"

If to summarize the characteristics of post-industrial society theory available in the scientific literature (see ${ }^{151617}$ ), they can be narrowed down to three main characteristics: first, the source of productivity and the growth of a new stage of social development is knowledge, information that is processed and extended to all sectors of economic activity through information technology; second, the main type of economic activity is production of services; third, leading role in the social production of professions associated with high intensity of knowledge and information, displacement of labour as a typical type of economic activity in industrial society, a qualitatively new type of activity - creativity.

The economic practice of the last decades has confirmed the findings of the founders of the theory of post-industrial society, as the experience of economic, social, political and cultural development of the leading countries of the world confirms the peculiarity of all these essential features to the realities of the late XX century - the early XXI century. For example, in modern society, the information industry is extremely large. Now, each of us lives in an extremely dynamic, knowledge-based, interdependent information society. This fact is confirmed by development rate of scientific and technological progress worldwide: it took 38 years for a radio audience of 50 million people, 13 years for television, 4 years for the Internet, 3 years for iPod, and only two years for Facebook; international social media MySpace has more than 200 million users, so if MySpace were a country, it would be the fifth country by population. The increase in the number of authorised users is 250 thousand people per day; Google deals with 31 billion search queries

14 Брежнєва-Срмоленко О. В. Інтелектуальна складова в структурі елементів нової економіки. Актуальні проблеми економіки. 2010. № 3.

15 Белл Д. Грядущее Постиндустриальное общество: опыт социального прогнозиро-вания / Перевод с английского Иноземцев В. Л. Изд. 2-ое, испр. и доп. Москва: Academia, 2004. 788 c.

${ }^{16}$ Кастельс М. Информационная эпоха. Экономика, общество и культура. Пер. с англ. под науч. ред О. И. Шкаратана. Млсква:ГУ ВШЭ, 2000. 608 с.

17 Тоффлер Э. Революционное богатство: как оно будет создано и как оно изменит вашу жизнь; [Пер. с англ. М. Султанова, И. Цыркун]. Москва: АСТ; АСТ МОСКВА; Профиздат, 2008. 596 с. 
every month and as far back as 2006, they accounted for 2.7 bn.; growth dynamics in Internet-devices: in 1984 there were 1 thousand pcs, in $1992-1$ million pcs, in $2008-1$ billion pcs; the first commercial SMS message was sent in 1992. Today, the number of messages sent and received per day exceeds the number of people across the globe; experts have found that the "New York Times" issue publishes more information per week than a man received in the 18 th century over a lifetime ${ }^{18}$.

It should be emphasized that along with the growth in information volume, the level of its use also grows. This process was most noticeable in mid-to-late XX century when experts calculated that information volume doubled every 20 months while in the XIX century - during 50 years. Here are the dynamics of the process: from the beginning of A.D., doubling of knowledge took place until 1750, the second doubling was recorded until the beginning of the XX century, the third - until 1950. Then the process of knowledge doubling was more accelerated: until 1970 - for ten years, after 1970 - every 5 years, and since 1991 every year. By the early XXI century, information resources have increased by 250 thousand times ${ }^{19}$. N. Bontis argued that since 2010, the world resources of knowledge and information should double every 11 hours $^{20}$. It is information awareness that determines the educational and professional level of a person that determines its transformation from a biological being to a biosocial owner of knowledge and qualifications. Such owners form an intellectual class that becomes more independent than other social strata of the population ${ }^{21}$.

An agrarian society is based on human interaction with nature, industrial society - on interaction with the transformed nature, and postindustrial society - on interaction between people on the basis of intelligence and information. With the transition from agrarian to postindustrial type of development, the importance of knowledge is steadily increasing. At the same time, there is a shift in the distribution of people by business towards increasing employment in the tertiary sector

18 Грищенко I. М. Освіта та професійна підготовка фахівців у світлі Євроінтеграційних процесів. Актуальні проблеми економіки. 2010. № 7. С. 56-61.

19 Утюж I. Г. Освітній потенціал особистості: Монографія: Запоріжжя: ТОВ «КСК-Альянс», 2007. 147 с.

${ }^{20}$ Bontis N. The strategies Management of Intellectual Capital and Organizational Knowledge. NY.: Oxford University Press, 2002. 740 p.

21 Утюж I. Г. Освітній потенціал особистості: Монографія: Запоріжжя: ТОВ «КСК-Альянс», 2007. 147 с. 
of the economy. Despite the complexity of organizing society and the slowdown in population growth, there is also an increase in life expectancy.

However, it is worth to take into account that economic growth also has detriments to the society. American scientist Mishan E. J., in his paper "The costs of Economic Growth", turned attention to the fact that attempts to achieve economic growth based on technological innovation or to accelerate it significantly will lead to such devastating consequences for the environment that the quality of human life will inevitably take a turn for the worse",22. This conclusion made the problem of economic growth limitation actual and raised a concern of the need to solve environmental problems. The author believes that the knowledge economy is one of the mechanisms for the prevention of destroying effects. It contributes to the improvement of environment as it plays an important role in the process of recognition by society of the ominous consequences of physical and biological processes. The very knowledge helps people to realise the need and ability to meet the needs by virtue of available resources without disrupting the balance of the environment developing invention and rationalization, which is the basis for future growth of domestic wealth.

However, growth is not an impulse to development. Therefore, to understand the mechanism of dynamic social changes that are achieved through the knowledge economy, it is necessary to distinguish its function as a factor for the development of the economic system.

First of all, one should pay attention to the fact that economic growth, which is attained through the growth of human and intellectual capital, contributes to increase in incomes of certain population stratum. G. Becker argued that economic growth during the last two centuries is explained by knowledge dissemination that plays a part in the growth of labour and capital as factors of production. In turn, the increasing dependence of production on the knowledge significantly advances human capital. In practice, this is reflected in the increase in remuneration (real income) of highly skilled employees as owners of that type of capital.

In modern conditions, the remuneration is becoming the basis for formation of completely new quality of social power, namely, new middle class. As it is known, the middle class of a mature industrial

${ }^{22}$ Mishan E. J. The costs of Economic Growth: Oxford University Press, 1993. 256 p. 
society consisted of such segments of the population as small entrepreneurs, businessmen, artisans, that is, groups of the self-employed population - petty bourgeoisie. Near $60 \mathrm{~s}-70$ s of the XX century, it was formed new class which involved groups of highly-paid employees: managers, freelancers, academics, educators and media professionals, trade and engineers, teachers, civil servants ${ }^{23}$.

If the traditional middle class was the owner of the means of production, then the representatives of the new middle class own the human capital the dividends of which bring them a basic profit. Like the regular employee, the owner of the human capital possesses labour, however, the employer pays him the basic part of the income not for physical and intellectual abilities, but for the capital at his disposal. The more complex human capital is as a resource for production (education, experience, skills, reputation, etc.), the more it acquires rarity and, respectively, increases in the labour market price.

Thus, the knowledge economy is the most important factor in increasing the level of personal income of those categories of population that are today forming the new middle class.

The income of the middle class improves its value to society as a consumer, as well as an entity that accepts and sets patterns (models) of consumer behaviour. The specific nature of the new middle class is to deal with productive activity which provide the functioning of highperformance modern productions, carries creative and productive functions. Human capital also makes its bearers active participants in civil relations, a relatively independent social force. As a result, the new middle class plays the role of a stabilizer, a function of consolidation in the society of integrative processes and development of social partnership. Human capital also makes its bearers active participants in civil relations, a relatively independent social force. As a result, the new middle class plays the role of a stabilizer, a function of consolidation in the society of integrative processes and development of social partnership. Human capital also makes its bearers active participants in civil relations, a relatively independent social force. As a result, the new middle class plays the role of a stabilizer, a function of consolidation in the society of integrative processes and development of social

${ }^{23}$ Шкаратан О. И., Ильин В. И. Социальная стратификация России и Восточной Европы: сравнительный анализ. Москва: Изд. дом ГУ ВШЭ, 2006. 468 с. 
partnership. Therefore, the knowledge economy, as a major factor in human capital, contributes to income growth and the formation of the middle class as a leading social power and factor of development.

One of the greatest obstacles for sustainable and stable development is inequality. Economic theory and practice have conclusively proved that uncontrolled and deep income differentiation is a direct threat to stability of the society. According to the Pareto principle, if the distribution of low incomes is subjected to acute and unexpected fluctuations then when it is reached their higher level, it gains stability ${ }^{24}$. Thus, social stability of the society as one of the main conditions for its development is a result of high level of the personal sector.

The knowledge economy contributing to the growth in prosperity through the receipt of dividends from human capital influences income equalization and promotes social equality. In fact, it dissolves social barriers as it increases the social status of the individual and, as a consequence, reduces the gap between the majority and the elite in society. As P. Krugman says "property is not a determinative basis for the elite status any more. Multi-billionaires earn a large share of their income in the form of benefits for their work" 25 . Consequently, the knowledge economy plays an important role in providing economic development, on the one hand, influencing stability of society and, on the other hand, creating social force which is objectively interested in social transformation and progressive development in social production and revenue sharing.

Meanwhile, the knowledge economy plays a pivotal role in the socialization of individuals, the formation of the regulatory component of their economic activity using the introduction of social norms and rules in the range of value orientations of the individual. Studying the economic development of countries through a system of criteria that characterize quality of life (nutrition, health, safety, dwelling), E. J. Mishan in "The Economic Growth Debate" identifies the additional components of this system, namely: family, religion, traditions and customs ${ }^{26}$. The researcher argues the sustainability of morality of any moral code is necessary to man as the basic varieties of human communication (friendship, love,

${ }^{24}$ Парето В. Компедиум по общей социологии. Москва: Изд. дом ГУ ВШЭ, $2008.511 \mathrm{c}$.

${ }^{25}$ Krugman P. The Concience of a Liberal. New York; London, 2007.

${ }^{26}$ Mishan E. J. The Economic Growth Debate. Allen \& Unwin, 1977. 280 p. 
mutual help, etc.) that satisfy social needs and needs for respect and selfexpression. E. J. Mishan says "The unrestricted continuation of the industrial expansion that we have been observing for two centuries throughout the Western world will lead to a slow but inevitable disintegration of the social order, to the collapse of all kinds of discipline and authority fixed in this order, and to the fact that people will find themselves in social and moral vacuum which is likely to be filled by a totalitarian state" 27 .

F. Hirsch in "Social Limits of Growth" drew similar conclusions. The scientist points out that "economists who have been engaged in economic growth for too long have paid very little attention to its moral fundamentals" ${ }^{, 28}$. According to F. Hirsch, qualities that have proven to be directly related to the "spirit of capitalism" and economic growth, namely: honesty, benevolence, restraint, obligation, all of them are among the values based on religious belief. Hirsch considers the growing dissatisfaction and glut with those "positional" benefits, which modern industry makes widely available, as other type of restrictions influencing economic growth. The rapid growth of similar benefits reduces their attractiveness to the average consumer worker that weakens motivation to work and reduces savings as a basis for investment. As a consequence, the economic growth is hindered. Naturally, values promoting economic habits maintain an attitude to work as a vital variable essential to ensure the growth that destroys them.

Findings of E. Mishan and F. Hirsch justify that at present, a society where social consensus is reached based on values shared by the majority of the population is more stable and inclined to progressive development. The knowledge economy transmits and transfers knowledge and gained experience from generation to generation, fixes sociocultural values in the individual consciousness leading to their adoption and transformation into an orientation component of the activities of economic entities ${ }^{29}$. In doing so, it creates conditions for the implementation of the management functions of the economic mechanism of the economic system, contributes to the achievement of economic policy goals.

${ }^{27}$ Mishan E. J. The Economic Growth Debate. Allen \& Unwin, 1977. 280 p.

${ }^{28}$ Hirsch F. Social Limits of Growth. Routledge, 1978. 232 p.

${ }^{29}$ Пилипенко Г. М. Інституціональні чинники державної та ринкової координації економічної діяльності: монографія. Д.: НГУ, 2012. 293 с. 
The knowledge economy influences the components of economic development, first, in the aspect of favouring economic increase as one of the factors of GDP growth and, second, as leverage over an opportunity to get education and improve population literacy, ensure environmental security and access to social benefits, creation of conditions for economic security and stability in society.

However, progressive development is impossible without the formation of its direct driving force - a person as a highly developed and harmonious personality possessing a sufficient level of human, cultural and social capital. The welfare of the people will be possible only when behaviour model necessary for this purpose will be consciously formed in the minds of citizens and become a leading social reflex.

As it is known, the cultural capital of a person forms sociocultural values and behaviour standards based on these values. The knowledge economy is the sphere where certain components of cultural capital are formed and the motivational factors of the economic behavioor of the subjects are established, which in the future act as regulators of their economic activity. It is crucial to accept those "rules of the game" which are foundation of economic and social order in society and to recognize them as legitimate for stable development.

Social capital is formed through training and education based on the achieved level of cultural and human capital. Acquisition of cultural values and acceptance of them as values orientations of activity promotes achievement of coordination effect and stability in a society. However, to make progressive changes in that sort of society, the activity and high social mobility of its members is essential. The ideological convictions of people based on a high level of education and intellectual qualities of the population play a major role in achieving the above goals. People must have core knowledge of the objective laws of economic, political and social development of society, the mechanisms of its changes and transformations. Due to education, the knowledge is formed and devolved to the next generations, as well as it is realized the process of creation and education of the future economic, scientific, cultural and political elite of the society which influences progressive development. Overall, develops personality and citizenship, establishes values of trust, equality, freedom, democracy, and thus creates components of social capital.

The above brings one to the conclusion that the knowledge economy is a factor in social change, as it develops the creative potential of each 
individual and, thus, acts as the most universal resource of civilization. Overcoming the old foundations of society is possible only because of the intellectual evolution of its members. A. Conte suggested about it confirming that "ideas rule the world and cause a ruckus in it. At the last, the whole social mechanism relies on people's opinion"30 that "intellectual evolution should be a priority as a basis of all human development: thy history of human spirit is at the head of history of society. Knowledge leads to predictions, predictions - to action, and action drives the need in knowledge" 31 .

Thus, the knowledge economy, forming qualitative characteristics of productive forces and creating conditions for implementation of managerial functions of economic mechanism, is one of the factors of economic growth and development of the postindustrial society. At the same time, due to the influence on other social systems, it promotes progressive socio-economic development. That position of education makes it one of the key determinants of the modernization of society and requires redouble attention to the parameters which ensure its effective functioning.

\section{CONCLUSIONS}

Today it is indisputable that the knowledge economy and the development of post-industrial society have a close interdependent relationship. The need of society in a man as a highly developed personality is realized through the establishment of the principle of humanism in relations between people, through the increasing importance of creative initiative. The knowledge economy has a leading role in the identification of society as a whole and of each individual in particular in specific historical conditions.

Knowledge production in a post-industrial society turns into a major national task. And countries with insight into the trends of world development have come to the fore of post-industrial civilization. The above is also about our country. The development of precise technologies based on informatization of work culture is our only chance not to fall down to the slums of the Third World; to rely on the main natural resource - intelligence and education of the people and to lead the government to support that sort of orientation to the best of ability. There

\footnotetext{
${ }^{30}$ Conte A. Course de philosofie positive. T. 1. P., 1830. 630 p.

${ }^{31}$ Ibid.
} 
are no problems more important than the development of the knowledge economy and the education of the master, even in the context of a crisis economy. These are the demands of a post-industrial society without which any steps towards development will be fruitless.

It is in the age of globalization when it is borne in upon that the knowledge economy is not a private matter, not the result of personal preferences but a social technology of human production, his abilities and skills the realization of which can lead the country to a new stage of development.

It is clear that the dynamics and transition rates of the economy in the post-industrial era depend to a large extent on the efficiency of the use of the results of creative activity of man. For this very reason, one of the major challenges, which needs a constant attention, is the creation of an effective system for production, protection, reproduction and use of intellectual potential. In particular, it is essential to lay the groundwork for the development of the economy sector where knowledge plays a decisive role. At the same time, it should be noted that the task to build postindustrial economy is impossible without the mechanism.

\section{SUMMARY}

The paper considers precondition for the development of the knowledge economy and its influence on the formation and development of postindustrial society as a paradigm of the modern development. It analyses the knowledge economy as a kind of economy where information and knowledge obtained on its basis play a pivotal role. The basis of that kind of economy is to create, spread and use knowledge to ensure competitiveness and innovation-driven development. The author studies the essence of the concept of postindustrial society where the top priority in the economy proceeded from predominant production of goods to the provision of services, research practice, organisation of the education system and improvement of the quality of life. It is considered information influence on the formation of the concept of the knowledge economy. The interrelation of human capital theory, intellectual capital theory and the knowledge economy is analysed. The author envisages the interconnection of the establishment of postindustrial society in the context of solving economic, social, environmental and cultural problems. It is proved that the knowledge economy is the most important factor of boost in personal income of those categories of the population which are forming new middle class today. 


\section{REFERENCES}

1. Тоффлер Э. Метаморфозы власти: Знание, богатство и сила на пороге XXI века / [Пер. с англ. науч. ред., предисл. П.С. Гуревича]. Москва: ООО «Издательство АСТ», 2002. 670 с.

2. Machlup F. The production and distribution of knowledge in the United States. Princeton: Princeton University Press, 1962. 416 p.

3. R. L. Katz. New York : Praeger, 1988. 168 p.

4. Тоффлер А. Футурошок. СПб : Лань, 1997. 464 с.

5. Індекс економіки знань. URL: file: C:/Users/User/Downloads/ ebrd-knowledge-economy-index.pdf (дата звернення 25.05.2019)

6. Демократизация глобальной экономики. Роль гражданского общества. Доклад центра изучения глобализации и регионализации университета г. Варвик: пер. на рус. яз. Л. Проскуряковой, 2003. 128 c. URL: http://warwick.ac.uk/fac/csgr/projects /russianreport.pdf.

7. Українське суспільство 1992-2012. Стан та динаміка змін. Соціологічний моніто-ринг / [За ред. В. Ворони, М. Шульги]. Київ: Інститут соціології НАН України, 2012. 348 с.

8. Белл Д. Грядущее Постиндустриальное общество: опыт социального прогнозирования / Перевод с английского Иноземцев В. Л. Изд. 2-ое, испр. и доп. Москва: Academia, 2004. 788 с.; Гальчинський А. С. Економічна методологія. Логіка становлення: Київ: «АДЕФ - Україна», 2010. 572 с.

9. Krugman P. R The Conscience of a Liberal. W.W. Norton \& Co., 2007. 352 p.

10. Гальчинський А. С. Економічна методологія. Логіка становлення: Київ: «АДЕФ - Україна», 2010. 572 с.

11. Брежнєва-Срмоленко О. В. Інтелектуальна складова в структурі елементів нової економіки. Актуальні проблеми економіки. 2010. № 3. С. 4-12.

12. Тоффлер О. Метаморфозы власти: знание, багатство и сила на пороге XXI века / Пер. с англ. Москва: Аспект Пресс, 2004. 400 с.

13. Белл Д. Грядущее Постиндустриальное общество: опыт социального прогнозиро-вания / Перевод с английского Иноземцев В. Л. Изд. 2-ое, испр. и доп. Москва: Academia, 2004. 788 с.

14. Кастельс М. Информационная эпоха. Экономика, общество и культура. Пер. с англ. под науч. ред О. И. Шкаратана. Москва: ГУ ВШЭ, 2000. 608 c. 
15. Тоффлер Э. Революционное богатство: как оно будет создано и как оно изменит вашу жизнь; [Пер. с англ. М. Султанова, И. Цыркун]. Москва: АСТ; АСТ МОСКВА; Профиздат, 2008. 596 с.

16. Грищенко I. М. Освіта та професійна підготовка фахівців у світлі Євроінтеграційних процесів. Актуальні проблеми економіки. 2010. № 7. С. 56-61.

17. Утюж I. Г. Освітній потенціал особистості: Монографія: Запоріжжя: ТОВ «КСК-Альянс», 2007. 147 с.

18. Bontis N. The strategies Management of Intellectual Capital and Organizational Knowledge. NY.: Oxford University Press, 2002. 740 p.

19. Mishan E. J. The costs of Economic Growth: Oxford University Press, 1993. $256 \mathrm{p}$.

20. Шкаратан О. И., Ильин В. И. Социальная стратификация России и Восточной Европы: сравнительный анализ. Москва: Изд. дом ГУ ВШЭ, 2006. 468 с.

21. Парето В. Компедиум по общей социологии. Москва: Изд. дом ГУ ВШЭ, 2008. 511 с.

22. Krugman P. The Concience of a Liberal. New York; London, 2007.

23. Mishan E. J. The Economic Growth Debate. Allen \& Unwin, 1977. $280 \mathrm{p}$.

24. Hirsch F. Social Limits of Growth. Routledge, 1978. 232 p.

25. Пилипенко Г. М. Інституціональні чинники державної та ринкової координації економічної діяльності: монографія. Д.: НГУ, 2012. $293 \mathrm{c}$.

26. Патнэм Р. Чтобы демократия сработала. Гражданские традиции в современной Италии. Москва: AdMarginam, 1996. 429 c.

27. Conte A. Course de philosofie positive. T. 1. P., 1830. 630 p.

\section{Information about the author: Matiuk T. V. $\mathrm{PhD}$ in Economics,}

Senior Lecturer at the Department of Economics and Entrepreneurship, Odesa I. I. Mechnikov National University 2, Dvorianska str., Odesa, 65000, Ukraine 


\section{CORRUPTION CONCEPT AND ADVANCED ANTI-CORRUPTION SYSTEM IN UKRAINE}

\section{Muzychenko G. V.}

\section{INTRODUCTION}

Corruption today is fairly considered as one of the main problems of governance at all levels of public life. Corruption is a global phenomenon, which is inherent in all societies, regardless of the level of development and geographical location, but in each country the success of its struggle with its own. This, on the one hand, determines the global nature of the fight against corruption as a socio-legal phenomenon and, on the other hand, intends a certain locality, that means a national scenario of combating corruption in each country which takes into account the level of political and legal consciousness, historical traditions, the economic state of society, etc.

For the last 15 years due to the financial crisis during which the gap between the rich and the rest has increased dramatically, the very rich have game both national and international financial systems, and politicians have received massive contribution to support tax reduction whilst development has effectively stagnated - accusation of corruption have gain come to the fore ${ }^{1}$. It is one of the reasons of political corruption topic actualization in scientific research in Ukraine and most of European counties as well.

Corruption began to spread markedly during the period named «perestroika», when the massive looting of public property, budget money laundering had started with the help of corrupt officials and servants. Since the independence period has started the corruption stimulate the development of the shadow economy and as a worm was eating Ukraine. Mostly the reason of it was a fact that the commercialization of the national economy revealed the urgent need for various types of permits and licenses, which became a peculiar

${ }^{1}$ Muzychenko G., Koliada T., Churkina I. Impact of European Integration Process on the Necessity of Long-Term Budget Planning Introduction in Ukraine. Baltic Journal of Economic Studies, 2017. № 3 (5). P. 330-331. 
commodity with its user-value and price. All attempts to overcome corruption in independent Ukraine were unsuccessful. This has become one of the reasons for the 2014 Revolution of Dignity. P. Poroshenko in his inaugural speech called the first and the main task for Ukraine is to eliminate corruption that absorbed the entire country. The next president of Ukraine Volodymir Zelenskiy also pointed on the corruption as the biggest trouble for our country.

There are three aspects of corruption: political, socio-economic and legal. Proponents of the political aspect define corruption as abuse of authority, official position and administrative capacity in order to receive material repayment. Thus, it causes material and moral damage to the structure of state, the reputation of political power, and the prestige of the country on the international area.

Corruption is one of the functions of corporate governance based on an economic basis, therefore, the economic approach supporters tend to regard it as a form of official abuse, in which a direct or veiled deceptive purposes always insist. Corruption is considered as a complex social and legal phenomenon associated with the bribery of persons who are on the state or public position, with the gaining of additional incomes, benefits and welfares for doing intentional misconducts or being inactive against to the interests of the state and society.

The third approach sees in corruption a purely legal structure as the primary basis for unlawful activity or inactivity. Socio-economic and political factors of corruption are secondary or superstructures over its legal basis.

The fourth approach is also has a right to exist, whose supporters believe that the concept of corruption is complex and includes the political, economic, social, legal and moral spheres of social relations. Corruption is not a specific socially dangerous act, as it is inherent in any component of the crime, but may takes various forms - criminal, administrative, civil, disciplinary and other ${ }^{2}$.

\section{Conceptualisation of corruption and ant-corruption policy}

In order to identify the ways on corruption prevention in modern states, it is necessary to choose a certain model of its development.

2 Музиченко Г. В. Теоретичні аспекти визначення корупції як суспільнополітичного явища. Політикус. 2017. № 3. С. 33-37. 
Scientists (V. Adrianov, B. Baluyev, O. Busol and others) outline several basic models of corruption development, according to the conditional geographical names or customs of a particular country. In particular, the following models are known:

1. Asian (traditional) model. According to this model, not only any service, but even a simple performance of official duties by public person is impossible without appropriate remuneration. Inability or unwillingness to give a proper bribe is perceived in such a society as an attribute of a person's inability to solve his problems. In this case, corruption in the eyes of the masses is not a crime ${ }^{3}$. In such countries an unrelated posts appetites are punished by demonstrative «purges», which are perceived by the public consciousness as the renewal of legality. All this as a result contributes to the stability of the authority vertical because the change of players does not change the rules of the game.

2. The African model is characterized by the fact that the authority in such states is sold to a group of main economic clans that have agreed with each other, and ensure the reliability of their existence by political ways. According to O. Busol, the transition to this model is possible under the following conditions: the political power in the country remains unconsolidated; financial and bureaucratic groups squeeze their existence under the influence of self-preservation instinct and negotiate; an oligarchic consensus is formed between the consolidated financialbureaucratic groups and a part of the political elite ${ }^{4}$. For the country it means the rollback of democracy and the monopolization of the economy.

3. Latin American model. The admissibility of corruption allows the shadow and criminalized sectors of the economy to achieve power that can be compared to the state. Authorities are often drawn into a rigid confrontation with the mafia, which creates a «state in the state». The economic welfare becomes a task which is not only unachievable, but even secondary to other problems. However, the political instability that is characteristic of such countries increases the chances of establishing a dictatorship on the warp of fighting corruption, which in turn leads to the threat of transition to an African model ${ }^{5}$.

${ }^{3}$ Бусол О. Ю. Протидія корупиійній злочинності в Украӥні у сучасний період : монографія. К. : Ін Юре, 2014. С. 37.

${ }^{4}$ The same publication. - P. 38.

${ }^{5}$ The same publication. - P. 43. 
4. The European model is characterized by a relatively low level of corruption in the almost complete absence of grassroots corruption. This does not exclude the periodic origin of scandals related to the corruption of higher echelons. The low level of corruption in European countries is supported by a set of measures - institutional, organizational, legal, as well as the effective operation of tradition, culture and civil society institutions.

5. Corruption in the post-Soviet countries (corruption under a social contract). In such countries employees who receive salaries from the budget receive inadequate monetary support. At the same time, the state puts a blind eye to receiving remuneration from consumers of administrative services. The danger is that even after a substantial increase in official salaries, the desire and habit of receiving gratitude from the recipients of services, as a rule, does not disappear. That is why the reform of the public system of government is delayed for years.

6. The localized model takes place in societies where most of the population does not give and take bribes. But there are some spheres of economic or political relations where a certain stratum of employees who have the right to sign documents, as well as businessmen who are interested in these decisions, try to find a common language with the help of monetary remuneration ${ }^{6}$.

There are five main models of the combating corruption are described in detail in the scientific papers of Ukrainian and foreign authors:

1. The totalitarian model for combating corruption, which prescribes the comprehensive state control over the officials' behavior and a rigorous response to any deviation from the norms they have made. The disadvantage of this approach is the violation of human rights, since the totalitarianism is fundamentally incompatible with their implementation.

2. The authoritarian model for combating corruption is characterized by selective implementation of responsibility in accordance with the guidance of a manager. This model motivates attempts to get into authorities for the reasons of own security and impunity in the struggle for privileges and full powers, therefore, the processes of power degradation and its gradual tampering are factored into it.

${ }^{6}$ Muzychenko G. Advanced Issues of Legal Adjustment of Anti-corruption Activities in Ukraine. Development of National Law in the context of integration into the European Legal Space. Warszawa. 2018. P. 136. 
3. The oligarchic model of combating corruption assumes that the realization of responsibility is carried out in accordance with the clan approach - on the friend-or-foe principle. Since power is exercised by teams, they defend themselves from responsibility in all available ways, and in relation to strangers they collect juicy details and try to give them a way. Money in such a model is gaining weight, so it can easily be transformed into a criminal one. And the combating corruption itself becomes instrumental and looks as a mean of power struggle between the oligarchic clans. Lack of control generates a massive corruption at the grassroots level of public administration.

4. The liberal anti-corruption model means total irresponsibility, impunity and permissiveness. Such a state is observed during the periods of revolutions, when the new government has not yet taken over management functions or deliberately initiates destructive processes. Such a model is dynamic and sometimes there is a return to the authoritarian model.

5. The legal democratic model is largely embodied in the concept of the rule-of-law state. The realization of such ideas as the consistency of law and morality, the definition of a reasonable hierarchy of values protected by law, the equality of all before the law, the delegation of authority, etc. have the great importance here.

In the combating corruption, it is particularly important to ensure the equality of all before the law as one of the main principle of the rule-oflaw state concept. In particular, this concerns the minimization of legal and factual immunities.

An analysis of the manifestations of corruption in different countries proves that there is a post-Soviet model of combating corruption is reinforced in Ukraine now, although we can talk about certain evidences of the presence of an oligarchic model as well.

\section{Evolution of the Corruption Combating in Ukraine}

Combating and prevention corruption as a socio-economic phenomenon are carried out during all years of independent Ukraine's existence. Until now, unfortunately, it was not possible to overcome it, despite the active work in this area of legislative, executive branches of public authority as well as the law-enforcement bodies.

The historical periods of combating corruption in Ukraine can be systematized in this way: 
The first period - ideological (1991 - first half of 1994). At this time, the formation of the problem of combating corruption and putting it into a topical issue took place. At the same time, there were the processes of increasing corrupt in a supportive environment, that was formed as a result of the unreflective throwing into a market, the fictitious democracy, the total lawlessness, the political mob rule and slogans. Corruption as a socio-economic phenomenon was condemned by the members of the first democratic convocation for Verkhovna Rada of Ukraine (Parliament), such as Vyacheslav Chornovil, Stepan Khmara, Larysa Skoryk, Grigory Omelchenko, Ivan Bilas and others. Also these issues were covered in the speeches by the first president of independent Ukraine, Leonid Kravchuk. However, everything remained at the level of conversations and slogans. But it was also an example of struggle - the ideological one.

Under such favorable conditions, part of Ukrainian officials could not resist the temptation to become wealthy at public cost. The 25 billion UAH (according to current calculations) of state funds were directed to shadow in 1993. In 1992, there were 1182 crimes were carried out in commercial structures, half of them - looting financial resources, and 163 cases of bribery. In the first half of 1994, several bribe-takers were seized, but none of them was convicted.

The second period - a frontal attack on corruption (second half of 1994-1995). After his election, Leonid Kuchma made an important improvement of personal administration in the Ministry of Internal Affairs of Ukraine. As a result, in the second half of 1994, nearly 200 police officers were arraigned on a criminal charge for crime affiliations.

Using the administrative-command methods on corruption prevention and combating it could be a best characteristic for this period. The President of Ukraine signed the Decrees «On corruption prevention and other crimes in the sphere of economy», "On urgent measures to strengthen the fight against crime». The Law of Ukraine «On the Organizational and Legal Foundations of Fighting Organized Crime» was adopted. The challenge was shaken to the shadow authority, with an attempt to end corruption with one decree ${ }^{7}$.

${ }^{7}$ Розвиток національного права в контексті інтеграції в європейський правовий простір : Монографія Інституту Європейської інтеграції. - Розділ VII. Актуальні питання антикорупційної діяльності в Україні. - Варшава, 2018. - С. 138. 
At the end of July 1994, 200 crime scene investigation teams were created from the employees of the Prosecutor General's Office, the Ministry of Internal Affairs, and the Security Service of Ukraine to investigate particularly special economic crimes. However, as it turned out later, there were no reserves for their creation. In many districts of Ukraine was one employed investigator for 10-12 vacant places.

It should be noted that the Presidential decrees were directed to the past. That is, it was about well-known facts of bribery, abuse of official position, mafiosity and lobbying among Ukrainian officials. It was necessary to review all the suspended legal proceedings concerning MPs of different levels, the leadership of the ministries and departments because only among the MPs at that time there were about 500 law breakers.

Unfortunately, the frontal attack on corruption was unsuccessful. For large-scale work there were not enough reserves. On the proposal of the Ministry of Internal Affairs of Ukraine, the Cabinet of Ministers has allocated additional 22 thousand full-time employees. The tendency of the extensive way of combating corruption was determined: the number of law enforcers increased by increasing combating capacity.

An analysis of the combating corruption at this historical period showed that it was impossible to overcome it by individual measures; a comprehensive approach was needed, such as: adoption of sets of normative documents, restructuring of law enforcement agencies as well as the coordination of their activities at the state level. Such measures were distinguished at the following period of time.

The third period - coordination of efforts against corruption (1996-2000). During this period of time, a number of programmatic state normative acts were adopted: Laws of Ukraine «On Combating Corruption», «On the Concept of National Security of Ukraine», «On the National Program for Combating Corruption», «On the unsatisfactory state of implementation of measures to combat crime». They renovated the members of the Coordination Committee for Combating Corruption and Organized Crime under the President of Ukraine, created special units for fighting organized crime in the system of the Ministry of Internal Affairs, the SSU (the «C»department), the State Tax Administration, Tax Police and its special unit - the Anti-Corruption Department. 
On April 24, 1997, the President of Ukraine signed the Decree «On the Establishment of the National Bureau of Investigation of Ukraine». NBIU was planned to be created to strengthen the fighting organized crime in all its manifestations, especially with the corruption of officials and mafia groups. However, the decree was not supported by the Verkhovna Rada of Ukraine and in the end came into force only in 2018.

In 1997, the «clean hands» operation was conducted under the leadership of the President of Ukraine. But corruption has never been overcome. The fact that all these measures had commercial nature and mainly aimed at overcoming the consequences rather than the causes of corruption. Furthermore, the phenomenon of corruption was still not sufficiently studied.

Since 1998 the complexity and application of the methodology of the system approach has been intensified on the corruption prevention. Plans for urgent coordinated actions of state and law enforcement agencies to strengthen the rule of law and order in the country were adopted. A Governmental Working Group was set up to track the shadowing of the economy and develop proposals for its termination. The legislative framework was being improved. The Government prepared a program of economic development of Ukraine. On the basis of it the Government started to combat the corrupt criminal links in state bodies. The legal basis for the combating was the Decree of the President of Ukraine № 367 of April 24, 1998 «On the Concentration of the Combating Corruption for 1998-2005», Resolution of the Cabinet of Ministers of Ukraine of August 3, 2000 № 1050 «On the Plan of Measures to Combat Corruption for the year 2000».

The mechanism of prosecution of civil servants for improper fulfillment of duties wass being improved, which amended the Resolution of the Cabinet of Ministers dated March 4, 1995 № 160 «On Approval of the Procedure for Investigation». In November 1999, Ukraine, together with members of the Council of Europe, signed the Civil Convention against Corruption. In Ukraine, an inter-branch organizational and legal hierarchical deterministic system of combating the shadow economy and corruption was being formed. However, in spite of the taken measures corruption hadn't been overcome.

The fourth period - pseudo-combating corruption (2001-2004). At this time the class disintegration of society is clearly followed. Three classes were formed: very rich, middle class and the poor. Very wealthy 
people have created their capital not always through the accumulation of property at the cost of profits from entrepreneurial activity. There are shadow revenues there, including corruption.

The situation in Ukraine had a dangerous peculiarity, it strangled virtually all segments of the population and was oriented towards maximizing the opportunities for personal enrichment of corruption actors in cost of mistakes made during the reformation of the economy. Criminal elements had already become entrenched and began to occupy leading positions in the economy in order to move in the future to politics. The country had formed a stable corrupt system of power from the President of Ukraine to the head of the village council.

The fifth period - orange (2004-2013). This period of combating corruption is characterized by a number of loud statements at various levels of authority, in particular at the level of the President of Ukraine and the Cabinet of Ministers of Ukraine. There were significant personnel changes both in the center and in the local level. The process of investigation of corruption cases of civil servants was carried out.

The sixth period is modern. Its beginning is associated with the Revolution of Dignity and the election of P. Poroshenko to the President of Ukraine. This period is characterized by considerable attention to the fight against corruption. A new version of the Law of Ukraine «On Preventing Corruption ${ }^{8}$ is adopted, special independent bodies are created - the National Agency on Corruption Prevention (NACP), the National Anti-Corruption Bureau of Ukraine (NABU), the Special Anticorruption Prosecutor's Office (SAP), etc. In addition, the Law of Ukraine «On the Principles of Anticorruption Policy in Ukraine (Anticorruption Strategy) for 2014-2017» was adopted. In accordance with this law all public institutions and subjects of public law have to develop their own anti-corruption activities (programs) and measures for their implementation.

Creation in Ukraine of special law enforcement agencies - the National Agency on Corruption Prevention and the Special AntiCorruption Prosecutor, whose activities are regulated by law, in practice has not yet shown significant progress on combating corruption. On the contrary, their politicization and constant conflicts between themselves and other political institutions are observed. In particular, there is a constant

\footnotetext{
${ }^{8}$ Про запобігання корупиії : Закон України від 14.10.2014 року № 1700-VII.
} 
conflict between NABU, NACP, SAP and the General Prosecutor's Office. The situation was aggravated by the creation in November 2017 of another institution - the National Bureau for Investigations - a special law enforcement agency to review criminal proceedings against crimes committed by high-ranking officials (category A).

\section{Legal aspects of prevention corruption in modern Ukraine}

As the world experience shows, there are three main components of combating corruption are needed for its successful providing:

1) proper (perfect, adapted to the conditions of the country, stable) anti-corruption legislation;

2) its effective use by the relevant state authorities (lawenforcement activities);

3) the political willpower of the government on real combating corruption in all spheres and at all levels of authority ${ }^{9}$.

Each of these components plays a special role on the corruption prevention and combating, but the basic one is still the first one, since combating corruption in a legal democratic state is possible only on a legal basis - this applies to the law enforcement activities, to the expression of political willpower, and to all other measures, which are used in the field of combating corruption. The breaching the law for anticorruption activities is a way to abuse official position, arbitrariness, in which combating corruption will be carried out by the same corrupt means.

Anti-corruption legislation is a conditional term to a certain extent due to the fact that the significant part of the current legislation (constitutional, civil, administrative, economic, etc.) is inherently anticorruption because it is aimed at establishing and regulating social relations, including in the sphere of public administration.

History knows examples when corruption prevention was not limited by the law, but was also carried out by offence methods and means. Thus, the Italian police operated during the reign of B. Mussolini, who strongly opposed the mafia. Police fought the mafia with its own weapons, including the use of violence against persons suspected of being in contact with mafia.

${ }^{9}$ Кушнарьов І. В. Політична корупиія: порівняльно-політологічна концептуалізачія: монографія. Київ: Вид-во «Юридична думка», 2018. С. 135-156. 
In the narrow sense of the word under the anticorruption legislation should be understood those laws and other regulations or their separate rules, which establishes special legislative provisions for the prevention of corruption, determines the responsibility for the commission of corruption offenses, regulates the activities of public authorities or their special units, whose competence is the combating or preventing corruption. In this paper, the anti-corruption legislation is considerated in this sense.

The analysis of current legislation of Ukraine shows that the legal and regulatory framework for combating corruption includes the relevant articles of the Constitution of Ukraine, the laws of Ukraine, resolutions of the Verkhovna Rada of Ukraine, decrees and orders of the President of Ukraine, resolutions and instructions of the Cabinet of Ministers of Ukraine and other normative acts. In total in Ukraine there are about 100 legal act devoted to the solving the problems of combating corruption. Need to say that almost 80 acts passed by the Parliament, the President or the Government of Ukraine contain a direct reference to the term «corruption».

At the same time, the existence of such a number of legal anticorruption acts do not at all indicate that a perfect system of anticorruption legislation has been created in our country. The indicated acts were adopted at different times, by different bodies, for different purposes, and most of them - in the absence of a single scientifically grounded concept of combating corruption.

The Basic Law of our state contains a number of provisions that can be attributed to anti-corruption. In our opinion, the key provision is fixed in Art. 19: "The bodies of public administration and local authorities as well as their officials are obliged to act only on the basis, within the limits of authority and in the manner provided by the Constitution and laws of Ukraine»» ${ }^{10}$. This article in principle defines the framework of lawful conduct of officials of public authorities at state and local levels. It fixes several important points in the anti-corruption meaning: firstly, it determines that the officials can act only in the manner determined by them, and secondly, the grounds, the way of their actions, as well as their responsibilities are determined by law only. Essentially Art. 19 of the Constitution of Ukraine can be defined as the fundamental anticorruption legal norm of our state, because it does not

\footnotetext{
${ }^{10}$ Constitution of Ukraine.
} 
allow any deviations in the activities of officials of these authorities from the behavior determined by law.

A number of other articles of the Constitution of Ukraine specify these provisions or emphasize certain points related to the status of certain officials. Thus, Part 4 of Art. 103 of the Constitution stipulates that «the President of Ukraine may not have another representative mandate, hold a position in state authorities or associations of citizens, as well as engage in other paid or entrepreneurial activities, or to be part of the governing body or supervisory board of an enterprise having the purpose of making profits $\gg{ }^{11}$.

The same kind of restrictions are set for other senior state officials. In accordance with Part 1 of Art. 120 of the Constitution of Ukraine, members of the Cabinet of Ministers of Ukraine, heads of central and local executive bodies shall not have the right to combine their official activities with other work, except for teaching, scientific and creative ones during off-working time, to be part of the governing body or supervisory board of an enterprise having the purpose of making profits. According to Part 2 of Art. 42 of the Constitution of Ukraine, entrepreneurial activity of deputies, officials of state and local authorities is limited by law. Certain limitations are set for judges who can not belong to political parties and trade unions, participate in any political activity, have a representative mandate, hold any other paid positions, perform other paid work, except for scientific, teaching and creative (Part 2 of Article 127 of the Constitution).

Article 78 (Part 2 and 3) of the Constitution of Ukraine establishes restrictions for Members of Parliament of Ukraine. It stipulates: «Deputies can not have another representative mandate or be in the public service. The requirements for the incompatibility of the parliamentary mandate with other activities are established by law» ${ }^{12}$. In case of nonfulfillment of the requirement regarding the incompatibility of the deputy's mandate with other types of activities, the MP gets amotion by a court decision (Part 4 of Article 81 of the Basic Law).

It should be noted that after the entry into force of the Constitution of Ukraine, these constitutional provisions were ignored by many MPs, who at the same time held the mandate of a deputy and the senior positions in

\footnotetext{
${ }^{11}$ Constitution of Ukraine.

12 The same resourse.
} 
executive bodies, headed entrepreneurial structures, public institutions, banks, ect. Attempts to bring the status of parliamentarians in line with the Constitution, in spite of the legal certainty of the provision, succeeded in some cases only and after longstanding legal proceedings.

The Constitution of Ukraine contains a number of other provisions that can be regarded as anti-corruption. In particular, it concerns the requirements for the declaration of income and property (Article 67), the procedure for using funds from the state budget of Ukraine (Article 95).

The relevant general anti-corruption provisions that apply to certain requirements and restrictions related to the status of an official include the laws of Ukraine «On the Status of Member of the Parliament of Ukraine» (Article 3), «On the High Council of Justice» (Article 3), «On the National Bank of Ukraine»(Article 65), «On the Constitutional Court of Ukraine» (Article 16), «On the Prosecutor's Office» (Article 46), «On the National Police»(Article 18), «On Local State Administrations» (Article 12) and a number of other laws.

The main regulatory act, which focuses on special preventive anticorruption provisions, is the Law of Ukraine «On Prevention of Corruption» (2014). The existence of this Law refers Ukraine to the few countries established in the former Soviet Union, in which there is a special anti-corruption law, which provides for special restrictions for persons authorized to perform the functions of the state, provides for other requirements to them, defines signs of corruption offenses and establishes responsibility for their committing (the law of direct action).

The undeniable positive moment of this Law is that it contains the ethical and legal foundations of moral and lawful conduct of public servants and other persons authorized to perform the state functions. Its prophylactic character is determined by two main points: firstly, it provides for certain restrictions for persons authorized to perform state functions, preventing the coming of corruption relations into existence; secondly, it establishes administrative and disciplinary responsibility for violating these restrictions and committing the corrupt acts determined by it, and it serves as a preventive measure for more dangerous corruption manifestations, primarily criminal.

The main purpose of all prohibitions and restrictions is to prevent the use of persons authorized to perform the functions of the state, their official powers and other opportunities provided to them by official status, for unlawful personal enrichment, which may be carried out by 
engaging in entrepreneurial activity, unlawful promotion or creation of artificial obstacles for the implementation of such activities by other persons. All these «compatibilities», «promotions», «refusals» and others from the officials with authority are nothing more than a favorable ground for all kinds of official misconduct.

The law also provides measures for financial control, first of all, obliges public servants to declare their property status and incomes. It should be emphasized that the fixation of the property status and income of citizens through declaring - is widely used instrument to control the income of each citizen, their source and lawfulness. At present, Ukraine does not legally foresee the mandatory to declare property and incomes for all Ukrainian citizens. Although in the Constitution of Ukraine (Article 67) it is written: «All citizens annually submit to the tax offices at their place of residence the declaration of their property status and income for the last year in accordance with the procedure established by law» [9]. Analysis of the current legislation shows that at the legislative level the issue of declaration is regulated only for certain categories of citizens, in particular, public servants, other persons authorized to perform functions of the state, persons who are applying for these positions as well.

The given legislative base on declaration of incomes and property does not solve the problem of financial control over incomes and expenditures of public servants. In circumstances when the country does not establish a general declaration of income and property for all citizens, it remains possibility for public servants to conceal their incomes and property.

The current legislation of Ukraine, depending on the nature of the offense, establishes criminal, administrative and disciplinary liability for corruption offenses. Criminal liability for corruption manifests itself in the cases provided for by the current Criminal Code of Ukraine (CCU). The most serious among them is illegal enrichment, committed by an official who is particularly responsible (Article 367.3 of the CCU), for which the current Criminal Code of Ukraine may be sentenced to imprisonment for a term of five to ten years with deprivation of liberty to occupy certain positions or engage in certain activities for up to three years with the confiscation of property.

The analysis of sanctions of criminal law, which provides for liability for corruption manifestations of a criminal nature, shows that the 
current criminal law establishes a fairly strict liability for such an act. In particular, it concerns sanctions on bribery that are unreasonably overestimated. In their definition, they came from the fact that the more severe the sanction, the more effective it is in terms of performing the functions of punishment. However, this is not quite as evidenced by the jurisprudence. Courts to ensure the implementation of the general principles of punishment are forced to go beyond the sanctions and impose a softer punishment than prescribed by law.

Administrative liability comes for the commission of all offenses established by the Law of Ukraine «On the Prevention of Corruption» (2014). The peculiarity of the sanctions of the norms of this law is that both an administrative and the disciplinary liabilities are provided for, and also establish for other perpetrators of acts of corruption other negative consequences of a legal nature.

Section 13-A of the Code of Ukraine on Administrative Offenses clearly regulates administrative liability for the commission of corruption offenses. The most severe punishment is for the violation of the person's restrictions on engaging in other paid activities like an entrepreneurship in the form of imposing a fine from 300 to 500, and in the case of a repeated violation - up to 800 non-taxable minimum incomes of citizens with the confiscation of income from entrepreneurial activity or remuneration from work part-time with a deprivation of the right to occupy certain positions for one year.

\section{CONCLUSIONS}

The analysis of the legal regulation of anti-corruption activities in Ukraine proves that the main preconditions for the origin and spread of corruption in Ukrainian society are: political and economic instability in the country; the discrepancy of the income of most of the population with a real cost of living; imperfection of the system of public administration; delay in creating an effective system of work with personnel at all levels; lack of transparency, publicity in the activities of public authorities, lack of effective levers of public influence; low level of legal culture of the population, etc.

Corruption in every country has a certain national development model (Asian, African, post-Soviet, European, etc.), on the basis of which the national system of prevention and combating corruption is developed. The model of post-Soviet countries is now firmly established in Ukraine. 
This model includes some elements of the oligarchic model on combating corruption.

Ukraine has created a sufficient legal framework for effective prevention and combating corruption with a whole range of criminal, administrative, civil, legal, disciplinary and other measures. There have been some changes in the institutional provision of anti-corruption activities in Ukraine. In particular, the National Agency on Corruption Prevention (NACP), the National Anti-Corruption Bureau of Ukraine (NABU), the Special Anti-corruption Prosecutor's Office (SAP) and the State Investigation Bureau have already been created. In turn, the creation of the Anticorruption Court of Ukraine.

The world experience in combating corruption reveals that no legislative or administrative measures can be effective if the society does not have the political willpower for that. Therefore, in order to further improve the anti-corruption legislation in Ukraine, it is advisable to take the following measures:

- to cancel the practice of «blind» copying of the norms of foreign legislation, facile and slick application of the provisions and recommendations of international acts on combating corruption without taking into account historical, socio-economic, cultural and other peculiarities of Ukraine, the mentality of the population, forecasting the possible consequences of the introduction of those or other legal norms;

- to create an effective system of training, professional training and advanced training in the field of prevention and combating corruption for all subjects of public law in Ukraine;

- to complete the process of institutional provision of anticorruption activities in Ukraine through the creation of the Anticorruption Court of Ukraine;

- to ensure cooperation between the main institutions of anticorruption activity in Ukraine and so on.

\section{SUMMARY}

The current status of counteraction and prevention of corruption in Ukraine at the level of legislation and institutional support of anticorruption activity are studied. It is noted that during the years of independence in Ukraine, corruption has become one of the threats of national security and democratic governance, and the fight against it is recognized as one of the priorities of the national authorities. 
The anti-corruption essence of legislation is mainly to prevent a conflict of interests (personal and official), to define the legal framework of lawful and ethical behavior of a person authorized to perform public functions, to make corruption offenses a disadvantageous and risky thing, and eventually to achieve that person honestly and conscientiously fulfilled his official duties. Secondly, we need it for clear identification of the corruption crimes characteristics, to provide adequate measures of responsibility for their commission, to regulate properly the activities of public authorities and their separate units that directly prevent corruption.

For the present, the anti-corruption legislation of Ukraine is presented by the Law of Ukraine «On Prevention of Corruption», as well as relevant articles of the Criminal Code of Ukraine and the Code of Ukraine on Administrative Offenses. They are up to the requirements of the European legal field in form, but there are some problems with their practical application, which is mainly due to the lack of political willpower of legislators.

\section{REFERENCES}

1. Музиченко Г. В. Теоретичні аспекти визначення корупції як суспільно-політичного явища. Політикус. 2017. № 3. С. 33-37.

2. Бусол О. Ю. Протидія корупційній злочинності в Украӥні у сучасний період : монографія. К. : Ін Юре, 2014. 564 с.

3. Конституиія України від 28.06.1996 № 254к/96-BP. URL: https://zakon.rada.gov.ua/laws/show/254к/96-вр

4. Кушнарьов І. В. Політична корупиія: порівняльно-політологічна кониептуалізачія: монографія. Київ: Вид-во «Юридична думка», 2018. 408 с.

5. Про запобігання корупиіï: Закон України від 14.10.2014 року № 1700-VII. URL: http://zakon2.rada.gov.ua/laws/show/1700-18

6. Розвиток національного права в контексті інтеграції в європейський правовий простір : Монографія Інституту Європейської інтеграції. - Розділ VII. Актуальні питання антикорупційної діяльності в Україні. - Варшава, 2018. - С. 135-153.

7. Фоміна М. В. Корупція : сутність, причини, методологія оцінки. Академічний огляд Донецького нац. ун-ту економіки $i$ торгівлі ім. М. Туган-Барановського. 2012. № 2 (37). С. 36-44. 
8. Heywood P., Navot D. New trends in the Conceptualisation of Political Corruption. URL: https://ecpr.eu/Events/PanelDetails.aspx? PanelID=7675\&EventID=121

9. Muzychenko G. Advanced Issues of Legal Adjustment of Anticorruption Activities in Ukraine. Development of National Law in the context of integration into the European Legal Space. Warszawa. 2018. P. 133-151.

10. Muzychenko G., Koliada T., Churkina I. Impact of European Integration Process on the Necessity of Long-Term Budget Planning Introduction in Ukraine. Baltic Journal of Economic Studies, 2017. № 3 (5). 329-333.

\section{Information about the author:} Muzychenko G. V. Doctor of Political Sciences, Professor of the Department of Political Sciences and Law, State institution «Southern National Pedagogical University named after K. D. Ushinsky» 26, Starofrankivska str., Odesa, 65000, Ukraine 


\section{DEFINITION OF LOCAL SELF-GOVERNMENT IN THE CONTEXT OF LOCAL DEMOCRACY DEVELOPMENT IN UKRAINE}

\section{Naumkina S. M.}

\section{INTRODUCTION}

Democracy is the system that extends to large pluralistic societies with an ever-changing system of internal and external interactions in the first quarter of the XXI century. It requires a radical reorganization of the political system and institutions of power and governance, and therefore the discovery of new essential characteristics of democracy associated with specific forms and the degree of participation of the population in the exercise of power at all levels.

Now the main enemies of democracy aren't a monarchy or an oligarchy, as it was in last. Today the main theme, which associated with democracy, is not the justification of the idea of democracy through ethical, theological, philosophical or sound arguments, but concern for its fragility and the searching for ways to strengthen it.

Obviously, the task of preserving and consolidating democracy can be successfully solved of its nature. Therefore, attention should focus not on the diversity of definitions of this concept, but on its quintessence, the dominant purpose. We can apply the approach to understanding democracy, which is the most widespread in modern political science: «develop some set of rules and principles (the constitution), which will determine the order of decision-making in a particular association». Moreover, this constitution should be in accordance with one elementary principle - all members of the association should be treated as if they were all equally competent to participate in the decision-making process regarding the policy that the association intends to implement.

\section{Institutional basis of the nature of democracy}

A well-known political scientist R. Dahl, who introduced the term «polyarchy» into a new political lexis, substantiated the main differences between the modern nature of democracy and the main procedural criteria that form and act as the institutional foundations of the nature of 
democracy. There are five criteria: 1) effective participation; 2) equal voting; 3) understanding based on informativity (awareness); 4) control over the agenda; 5) Inclusion in society ${ }^{1}$.

In these criteria R. Dahl saw the real opportunities, which was provided by democracy. Effective participation should be understood as the active position of any member of the association, which should have equal and effective opportunities to present their views on the essence of this policy to other members of the association, prior to the adoption of the association policy all members of this society. Equal voting involves not only the fact that all members of the association had had the same opportunities for voting before the decision, and that votes of all members of the association are equally valid. The understanding based on awareness consists in the fact that each member of the association should receive equal and real opportunities for familiarizing with political alternatives and their likely consequences. The control of the agenda assumes that members of the association have exceptional opportunities to decide on which issues and in which order they are subject to discussion ${ }^{2}$.

Thus, the democratic procedures aren't been exhausted by the three preceding criteria.

Association policy is always open to change, if it's required by its members. Finally, the criterion of inclusion in the life of society is realized in the process of participation in the democratic process of adolescents. Such participation implies that all members of the association should have full civil rights, as provided by the first four criteria, and they have reached the age of majority.

In the conditions significant importance of democracy acquires the legal status of a particular member of the association. T. Parsons distinguished three phases of the development of citizenship, in which the establishment of legal or civilian boundaries of the behavior of the member of the association.

In the first phase, it determines newly the adjacent relations between the societal community (it's characterized by a complex network of interpersonal relationships and in which each member of society at the same time is a member of a number of associations created

1 Даль Р. О демократии. Москва: Аспект Пресс, 2000. С. 123.

2 Див. детал.: Даль Р. О демократии. Москва: Аспект Пресс, 2000. С. 123-167 
on various grounds - professional, national, religious, ethnic, territorial, etc.) and government or state. The manifestation of these new boundaries was the definition of «rights» of a citizen, which protection turned into the very first duty of the state. The second phase of the development of citizenship is connected with the participation of citizens in public affairs. It's institutionalized positive rights to participate in the election of ruling leaders and enshrined in electoral law in this stage. The third component of citizenship is the social care of the welfare of citizens, considered as «a part of public responsibility». Consequently, if civil rights and electoral law make it possible to independently realize their civil status, then the social component is connected with the creation of real conditions for the better use of these rights. It means an attempt to provide the general population with an adequate living wage, access to health care and education ${ }^{3}$.

The spread of education to the general population and raising its level are directly and closely related to the development of the civil complex in the members

of the association. The attention of T. Parsons idea is that the development of modern institutions of citizenship had made a significant contribution to the concept of nationality as the basis of solidarity socialist society.

Strong foundations of solidarity existed where religious, ethnic and territorial factors merged in the concepts of nationality in the past. there can be many religious, ethnic and territorial foundations, as they provide the general principle of citizenship in modern societies ${ }^{4}$.

In this place the role of the collective is institutionalizated and increased as the most important element in the structure of the social system, which functions and manifests itself as a «voluntary selforganization» (or association) in the conditions of modern society. The basis for such a self-organization is the social community, in the form of a corporate association of citizens who has a relatively complete agreement on its normative system and authority of leaders ${ }^{5}$.

3 Парсонс Т. О структуре соичального действия. Москва: Академический проект, 2000. С. 34.

${ }^{4}$ Там же. С. 161.

${ }^{5}$ Там же. O структуре сочиального действия. Москва: Академический проект, 2000. C. 168. 
Considering the process of formation and development of such associations, T. Parsons highlights their main characteristics, among them the main is its certain egalitarianism (equality), which most clearly manifests itself in the three phases of citizenship. The second feature of the associations is their voluntary nature. And although, according to T. Parsons, this principle cannot be applied with all harshness in situations of obedience to normative order or collective decisions containing the mandatory element, it is almost literally fulfilled when making decisions on membership in an association. The third characteristic feature of associations is the importance of procedural institutions as a special self-organization of human groups. And although procedural moments of particular importance are in the legal system, they also enrich the decision-making processes in any association both at the level of the representative and at the level of internal relations ${ }^{6}$.

An analysis of these criteria shows that they are equally important and applicable to all levels of human associations: both at the state level and at the level of local societies created on the basis of professional, cultural, national, territorial and other grounds. However, these criteria of the democratic process play the most important role in the establishment and functioning of the institution of local self-government.

The first, they correspond, agree and being in synergy with the everyday laws of human life and the processes of formation and existence of territorial communities, permeate and determine the dynamics of their functioning, «fasten» members of the territorial association in a single the whole, assuming and realizing the very possibility of its creation.

Secondly, on their basis, there isn't simply association of individuals, which is fixed by ties of a passive nature and based on the principle of common life; community characterized as «active», which has a «person», who find their refinement and consolidation with the goals and objectives that need to be achieved at the tactical and strategic levels of the existence of the association.

Third, these criteria aren't directed only to the formation of a territorial association as a single community of individuals living in the same territory, but also have a powerful «reciprocal effect» - they promote and stimulate the development of each particular individual

6 Див. детал.: Парсонс Т. O структуре социального действия. Москва: Академический проект, 2000. С. 165-176. 
member of the territorial community, forming it as «inhabitant» in the positive sense of the word, with all the plurality inherent in it local interests ${ }^{7}$.

The «local factor» is rather important in analyzing the relation and interaction of democracy, a democratic state (political) regime and civil society, which was made by the American scientist D. Held. He distinguished the next models of democracy: a) classical; b) direct; c) protective (defense democracy); d) developmental democracy ${ }^{8}$.

The main features of classical democracy are short terms of election to power posts; maintenance at the expense of the society of the administrative apparatus; availability of different ways to exercise electoral law; presence of a higher collegial body of sovereign power of the people. The subject of power regulation is all spheres of public life and citizens are involved in the exercise of legislative and judicial functions.

D. Held considered the main features of direct democracy, first of all: all public affairs are regulated by a specially organized administrative structure of the pyramid type (from top to bottom); the management apparatus receives for its activities the same remuneration as workers in other sectors; rotation in the control apparatus is carried out by means of the withdrawal of candidates by voters; the presence of a powerful structure of force law enforcement support.

The model of «protective democracy» is based on compulsory availability of competing power centers. Sovereignty necessarily belongs to the people, but it delegates a significant part of its power to legitimately elected statesmen. Power in the state is divided into executive, legislative and judicial. The institutional basis of stability is the conduct of regular elections in society, on which decisions are made on the basis of the majority of votes. The rule of the constitutional principles, which unambiguously establish a circle of fundamental rights and freedoms of human and citizen, and it can`t be limited to any political power.

D. Held formulated the basic principle of the functioning of the fourth model of the «developmental democracy»: «Citizen participation in political life is conditioned not only by the need to protect individual

7 Прієшкіна О. В. Місиеве самоврядування в Україні: правове регулювання безпосередньої демократії. Київ: Кондор, 2004. С. 24-26.

${ }^{8}$ Held D. Models of Democracy. Stanford: Stanford U.P., 1987. P. 34. 
interests, but also the development of a general awareness of civic unity» ${ }^{9}$. The defining features of this model of democracy are the constitution establishes a clear balance between collective and individual rights; the expansion of the management function carried out by the «bureaucrats», and the functions of lawmaking are exercised by the elected body; development of the system of local self-government; the influence of citizens on the processes of public administration is carried out both through the exercise of electoral law, and by the method of individual participation ${ }^{10}$.

The conclusion is based on the results of the analysis of democratic models. The «local» factor has a significant significance and is manifested in all models of democracy, but most clearly, visibly and reasonably. It functions in the model of the «democracy of development». There is an objective need for an analysis of local self-government and its correlation with democracy in different hypostases of its manifestation.

Among the different forms of democracy, national and foreign researchers identify as the supreme so-called "participatory democracy», when citizens participate in the process of making managerial decisions, including at the local level. At the same time, participatory democracy has both its advantages and the disadvantages (challenges) that need to be taken into account in practical activities at the local level.

At the same time, researchers identify certain threats (or certain difficulties) that may arise in the process of involving citizens in solving local issues ${ }^{11}$.

The first threat is the openness of the authorities' actions and the inability to hide the existing shortcomings in municipal management. A certain preventive measure against this threat is the wider involvement of citizens in solving local issues (not only informing but also seeking to find the optimal solution). However, the final decision is still taken by the local authorities responsible for the decisions made.

The second threat may be the populism of power. It would give something to somebody to gain some benefits in the future. Citizens don `t always agree on this, especially if the benefits are promising in too far

${ }^{9}$ Held D. Models of Democracy. Stanford: Stanford U.P., 1987. P. 34.

${ }^{10}$ Held D. Models of Democracy. Stanford: Stanford U.P., 1987. P. 35.

11 Посібник з питань партисипативної демократії (демократії участі) на місиевому рівні / В. В. Толкованов, А. К. Гук, В. М. Олуйко, В. Я. Прошко. Київ: Крамар, 2011. С. 36-45. 
away or if the population doesn't have a great deal of trust in the authorities.

The third threat is defined as the «blurring of responsibility», and it is a certain contrast to the benefits of the «division of responsibility», which was discussed above.

The fourth threat is defined as «time expenditures», because communication with the community takes a lot of time from officials of local self-government bodies. As a rule, communication with citizens is a mandatory element in job descriptions of employees in European countries, and such communication takes a significant part of their working time in certain categories of officials and politicians.

The creation of a legal basis for a democratic state in a rather short historical time in Ukraine, as in most post-Soviet countries, makes for the parallel development of a large number of normative legal acts, first of all, laws that would condition the formation, development and functioning of major democratic institutions. It belongs also to local selfgovernment and becomes a social environment of democracy, where the processes of formation and institutionalization of certain organizations take place the authorities, as well as certain forms of self-organization of citizens.

\section{The condition of development of local democracy in Ukraine (based on the analysis of the constitutional definition of local self-government)}

Finding out the place and role of local democracy in Ukraine can be done on the basis of an analysis of the constitutional definition of local self-government. According to Art. 140 of the Constitution of Ukraine, «local self-government is the right of a territorial community - residents of a village or voluntary association in a rural community of residents of several villages, settlements, cities - to independently solve issues of local significance within the constitution and laws of Ukrain» ${ }^{12}$. In this context, it is necessary to clearly identify the circle of subjects of local self-government and their priority. According to the same article 140 of the Constitution of Ukraine, the primary subject of local self-government

12 Про місцеве самоврядування в Україні: Закон України [зі змін. та допов., від 17.07.2015 № 650 - VIII]. URL: http://http://www.vinrada.gov.ua/zakon_pro_misceve_ samovryaduvannya_v_ukraini.htm(дата звернення 23.04.2019) 
is a territorial community - a set of residents of a certain territory, and not only citizens of the state, living in this territory. At the level of local selfgovernment within the territory of a territorial community, actors live in a certain territory and operate primarily as its residents. Under the territorial community (local community) should be understood as a set of individuals. They are permanently residing in a specified territory. This communities are linked to each other by territorial-personal ties that are systemic in nature. All other subjects of local self-government are formed by the territorial community with the help of forms of direct (direct) and indirect (indirect) democracy and are characterized by its secondary, derivative character.

The traditional approach to grading of forms of democracy is widely used, and it depends on the form of expression of the will of the people. The Constitution of Ukraine proclaims a comprehensive and complete democracy, as well as forms of democracy - direct and indirect (representative). The Constitution of Ukraine is established the Institute of Political Representation.

It was accepted to consider the representative form of government as leading in relation to the direct in the Soviet political and legal literature. This idea was enshrined in the Constitution of Ukraine in 1996, where a number of provisions show a higher level of its legal regulation, and it establishes its types, subjects, their powers, organizational and legal forms of activity, etc. Therefore, we cannot fully agree with M.I. Stavniichuk, who argues that today it is possible to state the fundamental changes in the priorities of the realization of democracy in the open spaces of Ukraine in favor of the immediate exercise by the people of the state power which belongs to him. It contributes to real engagement of citizens, to the management of state affairs and creates conditions for reducing the alienation of citizens from power, which always exists in any society, even the most democratic ${ }^{13}$.

It is believed that this tendency is correct in terms of its semantic load, logical construction. This is correctly defined, according to the strategic directions of the development of a democratic state, but unfortunately, it is not always fully «operational» in practice.

${ }^{13}$ Реформування місцевого самоврядування - запорука розвитку територіальної громади. URL: http://www.rv.gov.ua/sitenew/main/ua/publication/content/20903.htm (дата звернення 26.04.2019) 
This opinion is shared by the representatives of the Coordination Council on the reform of the Institute of Local Self-Government in Ukraine, which indicate that both forms of exercising power by the people (bodies of state power and bodies of local self-government) are equal and the list of forms of people the expression of will through elections, referendum and other forms of direct democracy is inexhaustible and can be specified by the norms of the national and local legal acts $^{14}$.

During the years of Ukraine's independence, attention to the forms of local democracy has been paid to the legal regulation of local elections, due to the

increased interest from them by the political forces of Ukraine and the international community. However, the legal regulation of this form of local democracy can not be considered stable and perfect. After all, several election laws had been passed in Ukraine before the electoral process began, with a radical change in key positions, in particular, on the way in which representative bodies they were formed. At the same time, certain provisions of the Law of Ukraine "On the bodies of selforganization of the population» contradict the norms of the current legislation of Ukraine. In practice, these regulatory gaps, the vagueness and ambiguity of the wording impede the creation and activities of the bodies of self-organization of the population and don't allow members of territorial communities jointly and under their responsibility to solve problems at the place of residence.

Over the past years, the Cabinet of Ministers of Ukraine has adopted several acts related to the development of local democracy. Thus, it was approved the procedure for facilitating the conduct of a public examination of the activities of executive bodies, which granted civil society institutions, bodies of self-organization of the population the right to conduct a public examination of the activities of executive authorities, in particular local executive authorities. The Cabinet of Ministers of Ukraine has recommended to local self-government bodies to disseminate the mechanism of conducting public examination on them. As practice shows, only a few local self-government bodies have taken advantage of

${ }^{14}$ Див.: Місиеве самоврядування в Украӥні: сучасний стан та основні напрями модернізаиії: наук. доп. / [редкол.: Ю. В. Ковбасюк, К. О. Ващенко, В. В. Толкованов та ін.]; за заг. ред. д-ра наук з держ. упр., проф. Ю. В. Ковбасюка. Київ: НАДУ, 2014. $128 \mathrm{c}$. 
this recommendation, which has the effect that civil society institutions today have no real opportunity to conduct a public examination of the activities of local self-government bodies ${ }^{15}$.

Consequently, we can conclude that the current legislation of Ukraine is imperfect and impedes its development in the issues of local democracy. And the current approach eliminates the initiative of the inhabitants and brings it to naught,

when the possibility of citizens' participation in the management of local affairs depends primarily on the goodwill of a government body or official. This leads to a decrease in public confidence in the government, promotes the strengthening of such negative phenomena as absenteeism and the alienation of members of territorial communities from attempts to independently solve topical problems of local development. The lack of effective mechanisms for solving problems leads in some cases to aggravation of social conflicts and the spread of such radical forms of public expression of will, such as pickets, rallies, roadblocks and other actions of civil protest.

The level of development of local democracy in Ukraine is a constant subject of monitoring of the European community and the European Committee of Local and Regional Authorities of Europe, which reveals a number of factors limiting the content of local self-government in Ukraine: the tendency to centralize the powers of national agencies; lack of a stable economic base at the local level; the weakness of the financial system of local and regional authorities; the lack of clear division of powers and administrative activity between central government agencies and local and regional authorities. It may result in intersection or duplication in the exercise of authority.

These trends contradict the provisions of the Law «About Local SelfGovernment in Ukraine», according to which state control shouldn't lead to interference with the exercise of local self-government bodies. Although the purpose of this limitation relates to a particular supervisory issue, it can be used more widely to restrain efforts by the central government to influence the allocation and exercise of powers to the detriment of local authorities and their right to self-government.

15 Про затвердження Порядку сприяння проведенню громадської експертизи діяльності органів виконавчої влади: Постанова Кабінету Міністрів України від 05.11.2008 3а №976 [зі змін. ma доповн., від 08.04.2015 № 234]. URL: http://zakon4.rada.gov.ua/laws/show/976-2008-п(дата звернення 20.05.2019) 
The development of local democracy and political representation on the ground is under the influence of the development of civil society in modern countries of the world and in Ukraine. Such interdependence of democracy and civil society can be carried out in accordance with one of four models: classical, direct, protective, developmental. The local factor is essential and manifested in all models of democracy, but most clearly, visibly and reasonably, it operates under the conditions of the latter model, which involves the participation of citizens in political life, which is conditioned not only by the need to protect individual interests, but also the development of a general awareness of civic unity. It is considered as a prerequisite for the introduction of high-quality political representation on the ground.

As to the theoretical measurement of the content of the local selfgovernment institute, it is worth analyzing the issues of local selfgovernment as a system with organized unity of elements that has the properties of self-regulation and self-reproduction. Every system is an element of a more complex and larger system, which with respect to this system is called macrosystem.

There is a danger of considering the system of local self-government as a phenomenon without consider the laws, principles of functioning of this macrosystem and their relationship with local self-government. It is inherently intelligently and purposefully evolving, as it happened and is quite satisfactory in essence, an element of social structure and social relations. Unfortunately, this is exactly what the evolution of the system of local self-government and its present state are being considered in many works of national researchers.

Self-government arises simultaneously with society and develops along with it. The need for it arises in connection with the need for joint activities, collective efforts, and therefore - the implementation of general management functions, without which society cannot function.

It is worth agreeing with the position that «... the prototype of today (and future) self-government was elemental self-regulation, manifestations of which appear at the earliest stages of sociogenesis, that developed under laws they were different from biological ones. The essence of such self-regulation, which was a prerequisite for the survival of a person in conditions of strict biological competition and adverse environmental conditions. 
It was to ensure the vital functions of the original prototype communities, the balance between the collective and individual interests» ${ }^{16}$. It is covered the distinction between self-government (which covers all manifestations of both spontaneous) and conscious selfregulation of social life and management (which is manifestation of only conscious self-regulation, which is carried out in order to achieve the corresponding goal).

There is a cognitive paradox of «spontaneous management» because the term management involves conscious action to achieve the goals. «Spontaneity» and "management" is categories that exclude each other. However, neither spontaneity nor consciousness is found in its pure form. It is more correct to speak about a certain correlation of spontaneity and awareness in management the assessment of the dominant components of the first or second component may be determined by the position of the researcher, the level of development of science and the so-called effect of authorization.

From the point of view the notion of self-organization and selfregulation is wider than the concept of social governance of the dialectical relationship between conscious and spontaneous in the regulation of social processes, because not all kinds of manifestations of social self-regulation can be implicitly attributed to management. Consequently, the management objectively cannot cover all aspects of public life, many of its aspects are regulated by spontaneous (objective) self-regulation, which cannot be determined as a management in the paradigm of modern science.

In its turn, spontaneous self-regulation may include both constructive, creative, and certain destructive, destructive potential, which is aimed at changing the outdated, regressive existing system of self-organization of society. It is impossible to define how to manage such forms of social self-regulation as wars, revolutions, revolts, and other social power conflicts, as a result of which there is a dramatic flowering of existing differences in society.

Thus, self-government is a category that is used to characterize any manifestation of self-regulation, self-organization, self-control. That is

16 Див.: Децентралізація публічної влади: досвід європейських крайн та перспективи України / [Бориславська О. М., Заверуха І. Б., Школик А. М. та ін.]; Центр політико-правових реформ. Київ: Изд-во О. М. Москаленко, 2012. 212 с. 
objectively inherent in any society, community, group as a holistic dynamic social system in which decision-making processes take place.

Society is a universal self-governing social system. It consists of a hierarchy of subsystems of a different nature capable of selfdevelopment. Self-government is a form of self-regulation, selforganization not only of society but also of other social communities of people (national, confessional, professional, territorial communities and other groups) in the process of which ensures the preservation of their integrity, identity, qualitative specifics, their self-reproduction and selfdevelopment.

Consequently, the notion of self-governance can be affected far from unambiguous phenomena and processes of social life. It is often interpreted in broad and narrow terms. In the broad sense, the comprehensive form of self-organization of society can be considered primarily a state that arose as a product of social development and to no extent is a force imposed on society from the outside. It is in this sense that the notion of state sovereignty is interpreted, which indicates the source and at the same time the object of power.

However, the term "self-government» is used in the narrow sense as a synonym for local self-government in modern foreign and national literature. That in a relatively autonomous management of public affairs is carried out by the population of the corresponding administrativeterritorial unit directly or through the bodies they have formed, and not through central authorities. In this sense, this concept was formed relatively recently, although ideas and practices of local self-government arose in ancient times.

The focus is mainly on the characterization of «statics» of local selfgovernment, and not its dynamics in such a narrow sense. At the same time, such an approach to the analysis of the phenomenon of local selfgovernment is objectively inadequate, because it does not reveal the very technology of its functioning, mechanisms of interaction of local selfgovernment with other elements of social structure, problems of duplicate contours, positive and negative feedback in the macrosystem society, because the rules of law cannot cover all aspects of local selfgovernment, which is much more complex and diverse phenomenon than it can be concluded, based on formal analysis.

That is why the characteristics of local self-government only through the rules of law, which determine the order of its implementation. It does 
not reveal in full the entire essence of this phenomenon of social life, which is hidden under the relevant normative wording. In this way, the internal conflict of self-government and governance, which can be explained although reflecting different aspects of one and the same phenomenon social being, and conditioned by the aspirations of any hierarchical systems to expand the influence and expansion of sovereignty.

The problem lies in a certain duality of the system of local selfgovernment, whose authority does not start either in this system itself or in the territorial community controlled by this system. Receiving authority on the basis of legal norms that have their source outside the specified system, local self-government does not have sovereignty, and therefore cannot be considered as a closed self-sufficient system. The inevitable conflict between the interests of the state and the individual is refracted in the conflict, the culprits of which are the territorial community and the system of local self-government. It is the existence of a system of local self-government that is determined by a system of compromises, a shaky balance of interests and not always a perfect system of checks and balances. Own interests of the system of local selfgovernment, as a kind of corporate structure, are in difficult relationships with the interests of the territorial community, which, formally being an element of local self-government, is not a hierarchical structure and has neither sovereignty nor authority. At the same time, the state authorities are inclined to consider the system of local self-government as a kind of vassal and every effort to limit the autonomy of local self-government, creating duplicate structures of the executive verticals. All this is characteristic, rather, for a complex dynamic system, which is in a state of unstable equilibrium, than for a static, stable and internally stable.

\section{CONCLUSIONS}

The general level of governance does not allow it today to qualify for international recognition as a state that meets modern democratic standards in Ukraine, which doesn't allow to consider the system of local self-government. It is a subsystem of the general political macrosystem, as effective and conforming to the specified standards.

The main markers of a developed civil society are the level of corruption, the level of citizens' satisfaction with the quality of their lives, the level of social protection, life expectancy. They point to the imperfection of the existing system of organization of society, and the 
imperfection of the system of local self-government. Therefore, the existing system of local self-government is rightly regarded as a dynamic system generated by political and social conflicts of interest that is in a state of permanent crisis and far enough from a stable state and functional perfection.

The power field of the existence of local self-government is built between the state and the community, creating the corresponding vectors of tension and a certain theoretical and legal conflict. In cases where local self-government is the successor to historically more or less independent self-government bodies of local communities, one can talk about the state as an integral unifier of interests in relation to autonomous entities. In the same cases, when local self-government arose as an attempt by the state to get rid of unpleasant and uninteresting functions for it, one can speak of «leaking» powers from top to bottom.

At the formal and legal identity of both these forms of local selfgovernment, their origin imposes an imprint on their essence and on the relationship between these local governments and society. The range is gone from the almost complete independence of territorial communities from state authority (Switzerland) to the almost complete subordination of local self-government to state authorities, to the simulativedemonstration functions performed by this institution in a society with simulation democracy (Belarus).

Understanding local self-government involves a more detailed and detailed study of this phenomenon in the plane of its practical manifestations. It can be as a multi-faceted phenomenon, as a system is characterized by processes that change the system itself over time.

Effective democracy and good governance are essential elements for conflict prevention, maintaining stability, promoting economic and social development, and hence for sustainable community development at all levels. The basic idea is that local authorities are closest to citizens and provides them with basic services, and at this level, citizens can quickly feel their involvement in the adoption and implementation of the most important decisions.

Taking into account the trends of the development of local democracy in the modern world is important for Ukraine and should be used in the process of modernization of the system of local selfgovernment. 


\section{SUMMARY}

The article is devoted to issues by the level of a modern democracy, which extends to large pluralistic societies with a constantly changing system of internal and external interactions. It requires a radical reorganization of the political system and institutions of power and governance, and hence the discovery of new essential characteristics of democracy associated with concrete forms and the degree of participation of the population in the exercise of power at all its levels.

The conclusions are based on the results of the analysis of democratic models. We can conclude that the «local» factor has a significant significance and it is manifested in all models of democracy, but most clearly, visibly and reasonably. It functions in the model of the «democracy of development». There is an objective need for an analysis of local self-government and its correlation with democracy in different hypostases of its manifestation.

Self-government arises simultaneously with society and develops along with it. The need arises in connection with the need for joint activities, collective efforts, and the implementation of general management functions, it cannot function without society. The trends of the development of local democracy in the modern world have the great importance for Ukraine. It should be used in the process of modernization of the system of local self-government.

\section{REFERENCES}

1. Даль Р. О демократии. Москва: Аспект Пресс, 2000. 208 с.

2. Парсонс Т. О структуре социального действия. Москва: Академический проект, 2000. 880 с.

3. Прієшкіна О. В. Місцеве самоврядування в Україні: правове регулювання безпосередньої демократії. Київ: Кондор, 2004. 336 с. $134 \mathrm{p}$.

4. Held D. Models of Democracy. Stanford: Stanford U.P., 1987.

5. Посібник з питань партисипативної демократії (демократії участі) на місцевому рівні / В. В. Толкованов, А. К. Гук, В. М. Олуйко, В. Я. Прошко. Київ: Крамар, 2011. 199 с.

6. Про місцеве самоврядування в Україні: Закон України [зі змін. та допов., від 17.07.2015 № 650 - VIII]. URL: http://www.vinrada.gov.ua/zakon_pro_misceve_samovryaduvannya_v_u kraini.htm (дата звернення 23.04.2019). 
7. Реформування місцевого самоврядування - запорука розвитку територіальної громади. URL: http://www.rv.gov.ua/ sitenew/main/ua/publication/content/20903.htm

8. Місцеве самоврядування в Україні: сучасний стан та основні напрями модернізації : наук. доп. / [редкол.: Ю.В.Ковбасюк, К. О. Ващенко, В. В. Толкованов та ін.]; за заг. ред. д-ра наук з держ. упр., проф. Ю. В. Ковбасюка. Київ: НАДУ, 2014. 128 с.

9. Про затвердження Порядку сприяння проведенню громадської експертизи діяльності органів виконавчої влади: Постанова Кабінету Міністрів України від 05.11.2008 за №976 [зі змін. та доповн., від 08.04.2015 № 234]. URL: http://zakon4.rada.gov.ua/ laws/show/976-2008-п (дата звернення 20.05.2019)

10. Децентралізація публічної влади: досвід європейських країн та перспективи України / [Бориславська О. М., Заверуха I. Б., Школик А. М. та ін.]; Центр політико-правових реформ. Київ: Издво О. М. Москаленко, 2012. 212 с.

\section{Information about the author: Naumkina S. M.}

Doctor of Law, Professor at the Department of Political Science and Law, State institution «Southern National Pedagogical University named after K. D. Ushinsky»» 26, Starofrankivska str., Odesa, 65000, Ukraine 


\section{NEW HOMO ECONOMICUS: CONTEMPORARY CONTEXT}

\section{Petinova O. B.}

\section{INTRODUCTION}

The Ukrainian scientific multidisciplinary discourse reflects the global valid trends in the study of the economic person. The thematic spectrum of research, which is in one way or another related to the development, application, references to models of economic person or its individual components is very diverse. Socio-philosophical research is intended to be the methodological basis of specific scientific research. This is fully supported by the existence of profound works by Ukrainian scientists dedicated to the study of economic (or related to this field) objects.

Analyzing the main social trends in the organization of socioeconomic relations, we came to the conclusion that it is necessary to comprehend the existing reality in the framework of complex sociophilosophical interdisciplinary research and to determine the guidelines for building the future of our state, the basis of which should be a new economic person managing the society of the social market economy.

With the transformation in all spheres of human being and changes in the social order, the patterns of human behavior, which were generally familiar to society, change. The gap appears between the image of a traditional type of man and society needs in the "new type" of man, which we call the new economic man. The traditional social type also exists (mostly these are older people), but new emerging economic conditions in which, unfortunately, the former personality traits that were targeted by the entire education and upbringing system in the country become irrelevant, hindered, and become an obstacle in the process of self-actualization and self-determination in life. Indeed, people want to act in accordance with the composition of their character, but their behavior either interferes with the achievement of economic goals, or the person is completely unable to act contrary to their beliefs. For example, such positive personality traits as credulity, openness to people, moderation under the market society conditions lose their value, and the aggressiveness, risk-taking ability, initiative, etc. become the priority. If in the Soviet society entrepreneurial people were called "speculators", nowadays it is considered prestigious 
and corresponds to the challenges of the time. Character traits that at one point helped to adapt to social conditions of the day do not meet the needs of the economy today, and economic development happens faster than character formation and the response of educational institutions and education to such changes; the gap between economic evolution, and psychological and behavioral evolution leads to the situation where in the course of ordinary economic activity the needs of both the individual and the society are no longer satisfied.

\section{The new Homo economicus: definition of the concept}

The French philosopher G. Bachelard said that the creator and the bearer of the future civilized society should be a person capable of overcoming ethnic and social isolation, and therefore able to live in the rhythm of millennia. Modern Ukrainian researchers state that the metaphysical dimensions of human being are aimed at comprehending the downturn of human existence, the problems of personality and consciousness destruction, the need to reconstruct their essence in accordance with the ideals of truth, goodness, beauty; self-understanding of ways individuals choose themselves as a subject of moral, aesthetic and spiritual action, focus on the higher "meta-existing" values of life is a process of self-realization, self-improvement, self-creation, which creates a bridge from the processes of material self-affirmation in a crisis society existence to spiritual higher existential states. The latter make a human human and contribute to positive self-determination, authentic selfrealization and self-creation, a process on which depend both the fate of a "lost society" and the fate of a "lost person", who must return their lost essence to become themselves as the highest value, mobilizing all mechanisms of holistic understanding of themselves and the world in their totality ${ }^{1}$. They go on to say that such methodological requirements for the anthropological model of Homo economicus as instrumental status, symbolism, constructiveness and idealization make it possible to draw the "most important methodological distinction" - to distinguish two concepts of Homo economicus: if the former considers Homo

${ }^{1}$ Соснін О. В., Воронкова В. Г., Постол О. С. Сучасні міжнародні системи та глобальний розвиток (соціально-політичні, соціально-економічні, соціальноантропологічні виміри). URL: http://pidruchniki.com/74058/politologiya/suchasni_ mizhnarodni_sistemi_ta_globalniy_rozvitok 
economicus as a purely theoretical model, sum of anthropological prerequisites and assumptions, in the second case we talk about the type of personality, with appropriate behavior, abilities, inclinations and value preferences. Therefore, we can conclude that Homo economicus in the second meaning is a "psychologized", subjective version of the ascending model, which relates to it as a conceptual notion of empirical realization, and they correlate with each other as a general and isolated, which determines the differences between logical and ontological status.

The notion "economic person of a new type" or in other words, we use the concept of "new economic person", fits quite well to indicate the image of the future man, which will become the basis of Ukrainian society and will meet the challenges of time. If as a basis we take the new model of economic person proposed by M. Storchev as a theoretical model, then the concept "new economic person" under the context of our study will refer to the "psychologized version," (market type personality). Thus, by "new economic person" we mean a socially oriented market person, characterized by a high level of economic culture, oriented towards the achievement of well-being, a high quality of life, social justice and security, has creative abilities, is capable of risk and rapid adaptation under the changing market conditions. Surely, rational thinking serves as its attribute. The new economic person, at the same time, is the social role that the individual has to play in society, because modern Ukrainian economic system requires major transformation, and the Ukrainian economy experiences this necessity to the full extent. Problems in the level of compensation, changes in demand for labor and strong competition reinforce the necessity to develop national entrepreneurship. The issue of competitiveness of a new economic person, which must be formed as an economic entity, is very relevant under the context of globalization processes in Ukraine.

The new Homo economicus must build Ukraine we can be proud of. We have ancient traditions and a rich cultural heritage, significant natural resources. The new economic person should not ask what the country can do for them, instead, they will seek the answer to another question: what they can do with the help of the state to fulfill their responsibilities, to protect their economic freedom and to realize their constructive intentions, and at the same time-for their country as a whole. Unfortunately, nowadays the creative initiative of citizens is often suppressed, and the state apparatus not only fails to help, but also 
impedes the achievement of new perspectives. History confirms that the main threat to freedom is the concentration of power, the state is required to preserve our freedom, and it is also an instrument through which we can benefit from our freedom; however, when power is concentrated in the hands of politicians, it becomes a threat to freedom, both economic and individual. In our opinion, functions of the state should be generally reduced to protecting the citizens (maintaining the law, order, etc.) and assisting in the exercise of economic freedom.

It is possible to distinguish objective and subjective factors of "psychologized" economic person formation. Objective ones include the environment, productive forces and industrial relations, socio-political life of society, national, family relations, etc. Subjective are the ideas of a person about themselves and their managerial activities when applied, in education, in upbringing, their feelings, thinking process, and understanding of their tasks. Often, researchers use the terms "condition" together with factors and generalize them. It should be noted that conditions become factors through activity and include those elements of objective and subjective conditions that have a decisive influence on personality formation. Thus, the terms "objective and subjective conditions" reflect the reality as it is, the elements of objective and subjective factors under different conditions are differently correlated; and subjective is nothing but an objective regularity, which is realized only as a subjective for each individual personality and is their worldview, feelings, passions, etc. The formation of individual and psychological features of the "psychologized" economic person, in our view, is determined both by the specific hereditary biological properties of the organism and by the social environment in which the individual lives and is raised. This is, in fact, the genetic and cultural level represented in the new model of M. Storchev's economic person.

The social mechanism of economy functioning and development cannot be considered without the social relations the new economic person enters, which brings its specific nature to any field, community or process in which the relations may be manifested. The worldview of the new economic person combines the unequal social positions of different social groups and classes, social organizations and institutions. Its economic behavior is realized through role-playing positions that include functioning at the theoretical and practical levels. Thus, through the comprehension of new knowledge and patterns of economic life through 
the social institute of education, the theoretical and cognitive function is realized, in predicting the probable prospects and tendencies of development of the socio-economic sphere and the economic future of the state the predictive one is realized; by providing the management system with highly qualified personnel accustomed to modern conditions and able to manage effectively - managerial; in the formation of market socio-economic outlook of all economic life participants, orientation to the modern view of the role of the new economic person in the construction of the future of Ukraine - ideological. In addition, the new economic person is a product of a market society, where the process of economic socialization is carried out in socio-economic relations, in which further they monitor socio-economic tensions in society by themselves.

The philosopher A. Herzen in his time noted that the dependence of man on the environment, on the age is beyond doubt, and this dependence is even stronger because half of the bonds are established behind the back of consciousness; there is a physiological connection here, one that can rarely be overcome by the will and the mind; there is an element of heredity that is brought with birth in the same way as face features, there is also an element of morality and physiology - education, which imparts history and modernity to the person, and finally, the element of consciousness ${ }^{2} \ldots$ So, the environment changes, personality changes, as well as its peculiarities. Accordingly, different historical ages in different social relations bring certain features, characteristic for their time, for their people, for their state, and the model of the economic person changes.

The process of formation and evolvement of a "psychologized" new economic person is a complex dialectical process that includes the conditions of life, upbringing, and education; it is, first of all, economic sphere, purposeful external influence of social communities, mass media, etc. In this case, the inner aspirations, beliefs, character, success are determined by how much the person wants to be themselves, how they want to meet the challenges of time, whether they are engaged in selfeducation and self-development. The individual and psychological features of an economic person are determined by social conditions. Thus, these processes are especially noticeable during the period of

${ }^{2}$ Герцен А. И. Избранные философские произведения. В 2 т. Т. 2. Москва, 1948. 368 c. C. 111. 
change of the country's economic system type, for example, in Ukraine the administrative command economy changed to a market one, which led to new, qualitatively different conditions of life, activity, management, respectively, and the economic person became qualitatively different. It is not the external conditions per se, but the economic activity of a person in these conditions, their active interaction with the environment that play a crucial role in the formation of individual characteristics of a new type personality, which we call the market type.

One cannot practically educate another person without "rewiring" their psychology, which, above all, is expressed through the mental properties of the individual. This problem is not only theoretical but also practical. Therefore, building our country, enhancing its competitiveness in the international market will depend not only on the implementation of modern IT technologies in the manufacturing process, but, above all, on the economic activity subject, who will work for themselves and for the benefit of the state. New principles of economic policy at the present stage include strengthening the role of economic methods and incentives in the country's economy organization, expanding the autonomy of regions, decentralization of power, maintaining the initiative of the regions, increasing the responsibility and material interest of employees in the results of their activities. Improving the forms of economy management, active participation of the working team in the development of plans for the future, taking into account non-standard creative approaches will give Ukraine the opportunity to take a prominent place among the highly developed countries of the world. Modern tasks of economic planning and stimulation require from each citizen the use of the mind, knowledge, initiative, intuition, display of one's best abilities; in their turn, new forms and methods of management must bring material, intellectual, moral satisfaction, an opportunity to reveal one's talents. Thus, the implementation of economic reforms is based on changes in the management psychology, and economic transformations depend on psychological transformations: it is necessary to replace the psychology of labor and management, with humanism remaining the main principle. The basic rule of organizing everyone's behavior should be creative search, scientific foresight, which requires the development of new traits in the character of each employee, the manifestation of their abilities and will.

The basis of economic reforms is a change in the psychology of the economic person. One of the main problems is the change in business 
ethics and, in fact, it is the most difficult one. The demoralization of the population, first of all, youth deviance, alcoholism, drug addiction, sexual misconduct are those diseases of the XXI century that are very difficult to combat. At the same time, for example, the nature of prostitution and the nature of money are analogous, in the context of goods/money material, alienated relationships prostitution becomes a symbol of interpersonal relationships. Prostitution was the oldest profession. It is unlikely, if the profession is understood as labor specialization in the times of the preclass society (hunter, cattleman, farmer), then we could supplement this list with it. It arises with the emergence of goods/money relations, and on their basis. From our point of view, there are no reasons for prostitution itself, there are, however, social reasons, contradictions of socio-economic development, which create various forms of deviant behavior.

Drunkenness is a very common social phenomenon. It reflects all the smallest nuances of the social environment, always restoring the lost positions and winning the new. Every time life confirms that it is impossible to eradicate drunkenness with good intentions only. Alcoholism occupies a dominant position among the youth subculture. The social impact and pressure of crime on society, the spread of certain moral norms, psychological contamination of the least unstable part of the population environment is a worrying reality of the present, which leads to a significant and stable deformation of value system. O. Khimchuk notes that such values as honor, dignity, modesty, charity, compassion, conscience, true love, justice, social training, good manners, religiosity, cultural values, politeness, and pride are not preferential for modern youth. Material values, as well as selfishness, cruelty, rudeness, are gaining importance ${ }^{3}$. Nowadays, such value as the responsibility of young people to their parents, and therefore to society, is lost as well. Equally important is the careless attitude of young people to the environment (vegetation, animals, water resources, etc.), which negatively affects the health, physical and mental development of the people. Based on the results of her research of the modern youth values system, S. Nezabitovskaya gives a leading place to material well-being. Family happiness is gaining more weight, but creative development and the aesthetics of life are losing their

3 Химчук О. Цінності сучасної молоді. URL: http://www.osvitata.com/osvita-tareligiya/tsinnosti-suchasno-molodi.html. 
relevance ${ }^{4}$. Now, the question is: how do we fight this? In our opinion, among the ways and means of fighting this problem in modern conditions, due attention should be paid to the social teachings of the church, because the general ethics of work lies in morality, and common prayer has always been a source of religious ethics, a high culture of professional partnership relations, professional morality, and lawabidingness.

\section{New ethics of management: philosophical aspect}

The question of the interrelation between ethics and economics is quite complex, but it is properly presented in socio-philosophical thought. Thus, ethics is the set of principles, rules, and norms of behavior adopted in a social environment or professional group (ethics of teachers, ethics of doctors, etc.). In addition, ethics is also understood as the doctrine of morality, which is a form of consciousness. Public morality is based on public opinion, human beliefs, traditions and habits. Morality and ethics are very closely linked; the moral qualities of an economic person are reflected in the actions, economic behavior in general, attitude towards people, family, work, and their responsibilities. The moral and ethics of the economic person are formed in the process of human experience accumulation, in certain historical conditions, and depends on the development of science, new technologies, and above all, on the renewal of economic life and the economic system as a whole. With changing economy comes changing behavior, changing relationships between people and their morals.

A. Sen, an American professor of Indian descent, widely known today as a thinker who directs economic theory to socio-ethical issues, was the 1998 Nobel Laureate in Economics "for his contributions to welfare economics". His book "On Ethics and Economics", is often called the treasure chest, it shows the organic connection between economic science and the philosophy of morality, and highlights the damage done to economic analysis by the preoccupation with economic behavior postulate. A. Sen distinguished ethics and engineering as two sources of modern economic theory. Disconnection the economy from

4 Незабитовська С. Цінності сучасного студентства. URL: http://nadoest.com/ cinnosti-suchasnogo-studentstva.

${ }^{5}$ Сен А. Об этике и экономике. Москва, 1996. 159 с. 
ethics is one of the important reasons of classical analysis insufficiency. The thinker divides the material economics and the welfare economics. Since ethical motives influence human behavior, they influence material processes acting as welfare factors. Modern economic thought can become more effective if it uses ethical factors, as they shape human judgment. However, to achieve it, it is first necessary to improve human proper ethical conceptions.

Thus, the main directions of economic theory identify the rationality of behavior with the internal independence of choice and maximization of self-interest. However, A. Sen doubts that the focus on the interest maximization is close to the true human behavior. In the Japanese economy, for example, there are systematic deviations toward a course of action based on concepts such as duty, loyalty, and good will. These circumstances helped to raise the level of individual and group economic efficiency. The thinker does not share A. Smith's conception, and at the same time writes about the possibility of such circumstances under which the pursuit of self-interest satisfaction can only be ethically justified, also tries to restructure the term "welfare": welfare should be distinguished in the context of personal virtues and achievements and in light of broader goals, such as distributive justice, coherence, and interdependence. A. Sen proclaims ethics and engineering to be the source of economic theory development. Ethical orientation is directed to the Aristotelian tradition, while the engineering approach is associated with the name of French economist and mathematician of the XIX century L. Walras. The problem lies in finding a balance between an ethically oriented and technically feasible approach. The distancing of modern economic theory from ethical theory impoverishes the fundamental science. In 1975, A. Sen delivered an essay "Smith Travels on the Ship of State," where he interprets the thinker's idea about human behavior of convenience, because the philosopher believes that personal selfish interest dominates in most people, and according to A. Sen, the concepts of "convenience" and "personal gain," should not be equated, because even A. Smith, explaining the term, understands it as a combination of thoughtfulness and self-control, which is not identical to selfishness, and that convenience is the most useful of the virtues of man as an individual ${ }^{6}$.

\footnotetext{
${ }^{6}$ Сен А. Об этике и экономике. Москва, 1996. 159 с.
} 
One of the directions for the development of ideas of philosophical and ethical school in economics is the theory of "quality of life," the essence of which V. Brandt associates with material well-being and growth of the economy as a whole, but says that where material desires are satisfied, the question about justice arises. What does prosperity mean if people are choking on smoke and debris? Therefore, the conclusion is that the economic growth should not be deified, such materialism is inhumane. The transition should be made from maximizing economic growth to optimization. The prosperity of the new quality requires a reorientation of economy, technology, and politics. There are a few determinants of the ethical problems emergence in professional activity and in general, in everyday life, such as insufficient level of moral consciousness development, lack of skills of ethical behavior and ethical relationships in business interaction ${ }^{7}$, and in our opinion, the most important problem of Ukrainian society is the clear uncertainty and inconsistency of ethical standards of behavior.

Traditionally, within the framework of ethics, such sections as axiology, aretology, feliology, deontology, thanatology, and the doctrine of justice are distinguished ${ }^{8}$. A core value in economics is utility, which can be expressed in value, profit or benefit. Among the virtues of an economic person we can distinguish thoughtfulness, ability to forethought, carefulness, all these qualities are a consequence of rationality and the desire for efficiency, the ability to generate a higher value in the course of their activities if compared to the value spent. Such virtue as the ability to fulfill given obligations intersects with deontology in ethics, and has a direct impact on contractual obligations, loans, interest on loans, and development of the capital market as a whole. The deontological aspect of economic activity is expressed in such terms as opportunism and information asymmetry. Happiness in economic science is associated with utility maximization, satisfaction of both material and intangible needs. Overall, the motivation for happiness can even be associated with the work process itself and with the economic life.

${ }^{7}$ Креденцер О. В. Інноваційність як важлива характеристика підприємницької поведінки менеджерів освітніх організацій. Актуальні проблеми розвитку організаційної та економічної психології в Украӥні. Тези I Всеукраӥнського конгресу з організачійної та економічної психології (29 червня - 2 липня 2011 року, м. Кам'янець-Подільський). Київ, Кам'янець-Подільський, 2011. С. 140-141.

${ }^{8}$ Разин А. В. Этика. Москва, 2006. 624 с. 
Thanatology is connected to understanding of time resources limitations, and is associated with organization life cycle, the problem of intertemporal choice, capital depreciation, choice between accumulation and cost, profit and risk, etc.

The study of justice is closely linked to ethics as a section of the economy (according to A. Sen), justice relates to the relations of distribution and redistribution, of property. This issue has recently been studied in the works of R. Malakhov, A. Hubar, V. Shabashev. In his work "On Economics and Ethics," A. Sen proposes to present the interrelation of ethics and economics with the use of theoretical and economic tools, that is to extend the economic imperialism methodology to the ethical sphere. In particular, an attempt to unravel the relationship between ethics and economics through a consumer choice model, a manufacture marginal productivity model, and a market pricing model is presented in R. Malakhov's article?.

The problem of a new economic person formation, in our opinion, has a close connection with the morally effective economic activity in the aspect of religion: from the internal to the external. The Compendium reads: "Real social change is effective and lasting as long as it is a manifestation of decisive change in personal behavior. True moral improvement of social life is not possible until it begins with a person and is oriented towards it: for "moral life attests to the dignity of the individual." The development of the moral qualities (justice, honesty, truthfulness, etc.) that are fundamental to a society that seeks to be truly "human" rests with man; it cannot be expected of others or entrusted to institutions. The task of every individual and in particular those who are endowed with various forms of political, legal or professional responsibility is to become a sensitive conscience of society and the first to attest to the civil coexistence worthy a person ${ }^{10}$."

V. Zhukovsky, the editor-in-chief of "Christian and the World," notes that until "...a person embarks on the path of inner change, purification, transformation, spiritual and moral maturity and integrity; does not dig into themselves in search of truth, goodness and beauty, all

9 Малахов Р. Г. Взаимосвязь этики и экономики: попытка формализации. Вестник Алтайской академии экономики и права. Барнаул, 2013. № 52. С. 15-18.

10 Компендіум соціальної доктрини Церкви. URL: http://www.vatican.va/ roman_curia/pontifical_councils/justpeace/documents/rc_pc_justpeace_doc_20060526_com pendio-dott-soc_uk. 
their external activity, no matter what good 'PR' or need it is covered with, will remain a servant of the sinful passions that motivate them... Effectiveness of work that is not blessed by God because it is based on sin has no solid foundation and will disappear during the first life trials. A professional in any industry, enslaved by sinful passions, becomes a source of further spread of spiritual illness, disharmony and moral degradation in society. Every personal sin is attributed to the total pathological degeneration of values in different strata of society, which eventually degenerate into 'structures of sin,' preventing any positive progression at all levels of society's life and activity. Alternatively, every healthy family or professional 'cell' of the social body has a positive effect on rehabilitation of everyone and everything that surrounds $\mathrm{it}^{11}$." V. Zhukovsky concludes with these thoughts, and one cannot disagree with him. The state of the anomic society of Ukraine has devastated and fouled Ukrainians to such a degree that it is only possible to restore trust in the state and build a new foundation of ethical relationships if they turn to their inner "self", to Christian spirituality as a source of human maturity and work efficiency, to manage their household, organize private business. It must be the basis for true management efficiency and entrepreneurial activity. In addition, the term "economy" from the Greek word oikonomia (oikos - household, dwelling, environment, nomos law), literally means the laws of housekeeping. The most important treatise on the economy of Ancient Greece is the "Oikonomia" of Xenophon. At the same time, the same concept of oikonomia is one of the most important ones in theology (as economy) and denotes divine providence for man and the entire created world, that means one term denotes the management of man and the management of God. Thus, only in combination the human management will be effective and successful. In the global business environment nowadays it is quite common to focus on such philosophical categories as "business ethics", "moral standards", "protection of human dignity and human rights", etc. Well-known brands and companies state that with the growth of spiritual values, both the profits of the companies and the general mood and ethical behavior increase proportionally, and the role of the leader in the enterprise involves making managerial decisions, resolving conflicts, realizing

11 Жуковський В. Журнал «Християнин і світ»: мета і завдання. Християнин $i$ світ. Львів, 2009. № 1. С. 3. 
oneself and at the same time taking into account the interests of people. The future is for the proactive and strong personalities who bear responsibility beyond the limits of their own "Self", the future is for the new economic person.

At the same time, one of the variants of the theory of value (the source of which is God) is neo-Thomism, which at the objective idealistic philosophical doctrinal level seeks to systemize faith and reason, religion and science into a coherent harmonious system. It is God who completes the neo-Thomistic hierarchy of values through the chain "individual common good - personality - religious values."

In our opinion, it is quite interesting to refer to the biblical understanding of the notion of wealth as a good in universal scope, beyond the country or nation in the study of an economic person who is concerned with gain, profit (as values), and a rational way of thinking. "Excerpts from the Dictionary of Biblical Theology" states: "By blessing the work of human hands, God completes and strengthens man $-\mathrm{He}$ creates them. But if a man forgets about God, then He destroys what is done without him ${ }^{12}$." Ukrainian researcher M. Homa ${ }^{13}$ in her works presents the detailed analysis of wealth and other economic categories in the Bible. Understanding the wealth (as a collection of material goods) as owning property, the amount of which far exceeds the vital needs of man, let us turn to the presentation of it in Holy Scripture. Thus, in the Old Testament wealth is presented as a blessing sent by God to a righteous man: "... Abraham was very rich in cattle, in silver and in gold ..." (Genesis 13: 2). The Lord enriches his chosen ones, but they must serve a particular higher purpose, no one is enriched for themselves only, wealth must serve thy neighbor. The subject of wealth is presented in the Book of Proverbs, the Book of Ecclesiastes, and the Wisdom of Sirach.

Let's look at some excerpts from these works as an example. "When a rich person stumbles, his friends will steady him, but if a poor person falls, his friends will have nothing to do with him. When someone rich makes a mistake, there are many people to cover up for him and explain away all the things he never should have said. But let someone poor make a mistake, and he gets nothing but criticism. Even if what he says makes

${ }^{12}$ Витяги із Словника Біблійного Богослов’я. Львів, 1996. С. 96-98.

13 Хома М. Біблійне розуміння багатства, або як християнам ставитися до матеріальних благ? Християнин і світ. Львів, 2009. № 1. С. 4-15. 
good sense, nobody will listen. When a rich person speaks, everyone is silent, and they praise him to the skies for what he says. But let a poor person speak, and everybody says, "Who is that?" They push him down if he so much as stumbles. There is nothing wrong with being rich if you haven't sinned to get that way. But there is nothing sinful about being poor, either. Only the ungodly think so.'(Sir. 13, 22-24) “...I went past the field of a sluggard, past the vineyard of someone who has no sense; thorns had come up everywhere, the ground was covered with weeds, and the stone wall was in ruins. I applied my heart to what I observed and learned a lesson from what I saw: "A little sleep, a little slumber, a little folding of the hands to rest - and poverty will come on you like a thief and scarcity like an armed man.”(Proverbs 24, 30-34)

M. Homa's main illusions and dangers of wealth are abuse of power and office, arrogance and superstition, belief in the power of wealth and the rejection of God. Although the church is separate from the state, the moral and ethical issues raised by religion are immanently inherent in everyone's economic behavior, regardless of the position you hold president, MP, doctor, lawyer, teacher, businessman, janitor, cleaner, etc. - there must be certain moral and ethical standards that are the same for everyone, and everyone must adhere to them. Absolutely all human effort is futile without God. And if this is not the case then everyone will have "their own truth." And we have what we have. The New Testament Gospel of Matthew says: "...Do not store up for yourselves treasures on earth, where moths and vermin destroy, and where thieves break in and steal. But store up for yourselves treasures in heaven, where moths and vermin do not destroy, and where thieves do not break in and steal..." (Mt 6: 19-20)

M. Somin while researching the main paradigms of Christian attitudes to the economic and social sphere distinguished four of them: "miracle economy," "moderate doctrine," "patrimonial property doctrine," "protestant ethics." According to the first doctrine, the Lord gives everything by faith, including material necessity. In fact, a "miracle economy" means the renunciation of any arrangement of socio-economic sphere. According to the "moderate doctrine" (the conventional concept outlined in the patristic period at the end of the II at the beginning of the III century by Clement of Alexandria) to be rich is not evil, property gives the means of subsistence, is the guarantor of public freedoms and moral development of the person. However, independence of wealth must 
be a prerequisite for owning it: it is not wealth man that owns man, but man who owns wealth. "Great Church Fathers Doctrine" (teachings of the Holy Fathers of IV - V centuries: Basil the Great, Gregory the Dialogist, Ambrose, John Chrysostom) is presented on a personal level, "psychology of one's own" (property is considered the strongest temptation, and its overcoming in rejection of it) and at the level of relations with neighbors it is "sociology of property" (community of property). Communism derives from Christian love, but is only possible in a society where there is no private ownership (in fact, the utopias of T. More and T. Campanella are examples). "Protestant Ethic" (M. Weber) considers welfare and wealth as positive Christian values. The desire to increase wealth through legitimate capitalist mechanisms is a virtue. For the new economic person from the four presented doctrines, in our view, the most moderate is the "moderate doctrine" and "protestant ethic." Market economy conditions bring a competitive environment to the life and work organization of Ukrainians, but competition must be fair.

The modern younger generation of Ukraine is a product of capitalist society. A new economic person must believe in their ability to change the country for the better at the macro level, and believe in the success of their own role in the process at the micro level, in the success of their business. They must love money, otherwise there will be none, but the wealth must not possess them. And the possession of wealth does not hinder the salvation of the Christian only "if he will manage the wealth well, while remaining indifferent to it."

Discussing the topic of the socio-economic dimension of Christian life, L. Padovese states that the earthly gifts that man receives from God for proper use, the devil through his temptation tries to use them so that they become a source of wrongness for man, and overcoming the injustices from which society suffers depend on the internal transformation of man, and not on the mere change of structures ${ }^{14}$, and O. Kashchuk continues this thought: “... when unrighteous people have a wealth of earth, they only think how to use gifts of the earth received from God for the evil ${ }^{15}$."

14 Падовезе Л. Отці церкви IV-V століття про соціально-економічний вимір життя християн. Християнин і світ. Львів, 2009. № 1. С. 28-31.

15 Кащук О. Августин та папа Григорій Великий про праведне і неправедне володіння земними благами. Християнин і світ. Львів, 2009. № 1. С. 32-33. 
Today, the topic of spirituality and business is trending among the clergy, entrepreneurs and caring people from various fields of activity. The father-doctor Prokopiy Lototsky tries to answer the question of determining the system of values of the businessman. In the sermons, he speaks of four common mistakes distiguished by the Holy Scripture. The first is that people when making their plans forget God, so it is not surprising that true success bypasses them: “... it is sad to see those who consider themselves Christians, but act as if there is no God, as if his dwelling place is somewhere in the church, on the yellowed pages of the prayer book, in the old rites"; the second mistake is that we take tomorrow for granted, we act as if tomorrow will definitely come, but remember that life is unpredictable and short, "... what is the time? The moment we live in." The third mistake is that it is peculiar for people to put off the good for later, and the problem of evil is not only evil itself, "the hidden trap is the postponement of worthy work for tomorrow... but tomorrow may not come." And the last, the fourth one is wealth controls people, and not people control wealth, "true wealth is the ability to use what you have ${ }^{16}$."

The Church's social doctrine emphasizes that the economy has a moral dimension. As in the realm of ethics economic arguments and demands must be taken into account, so in the realm of economics one must be open to ethical requirements: "in the economic and social life one must respect and develop the dignity of man, his vocation and the good of the whole society. After all, man is the creator, the center and the goal of all economic and social life ${ }^{17}$."

Spirituality must be an integral part of the new economic person as its organic component of social nature. Spiritual wealth gives another impulse to its rational economic activity, maximizing utility in social development. An important component of the phenomenon of the new economic person, spirituality is a sense of responsibility to God, to themselves, their people and society as a whole, for their actions, everyone has the right to make mistakes, but one should not avoid the

16 Духовність і бізнес. Чи можливе поєднання? Зовнішньоекономічний кур'єр. Львів, 2016. Січень-лютий. С. 21. URL: http://lcci.com.ua/wp-content/uploads/ 2014/03/ZK-1-2016-web.pdf

17 Компендіум соціальної доктрини Церкви. URL: http://www.vatican.va/ roman_curia/pontifical_councils/justpeace/documents/rc_pc_justpeace_doc_20060526_com pendio-dott-soc_uk.pdf 
state of metanoia. As a phenomenon of human existence, repentance exists in a distinct system of moral relations well-established by society. Only the people, community, society have the right to a final sentence.

\section{CONCLUSIONS}

The new economic person should become the engine of economic development in Ukraine, acting as the driving force that builds the economic life of society as a whole. By uniting into groups, organizations and with relevant economic institutions, the new economic person becomes the subject of socio-economic processes and a component of socio-economic development. The absolute priority of self-interest as a motive for economic activity makes it possible to draw conclusions about the ethical side of an economic person behavior, and at the same time may speak about the deviation of their economic behavior from the socalled "standards," which may be motivated by sympathy for another, kindness, irrational unconscious urges. Becoming a new economic person in Ukraine requires a qualitatively different economic system that will become the "basis" for changes in the "superstructure."

\section{SUMMARY}

The article suggests the definition to the concept of "new economic person." The author distinguishes Homo economicus as a theoretical model and sum of anthropological prerequisites and assumptions, and Homo economicus as a type of personality with appropriate behavior, abilities and value preferences. The objective and subjective factors of the psychologized Homo economicus formation are considered.

The way to form a new economic person is to change the ethics of management. One aspect of this issue is the close connection with morally effective economic activity in the aspect of religion. The moral improvement of social life must begin with and be guided by the individual.

\section{REFERENCES}

1. Витяги із Словника Біблійного Богослов'я. Львів, 1996. C. $96-98$.

2. Герцен А. И. Избранные философские произведения. В 2 т. Т. 2. Москва, 1948. 368 с. 
3. Губарь А. И. Собственность в системе социальноэкономических отношений. Вестник Алтайской академии экономики и права. Барнаул, 2010. Вып. 1 (14). С. 7-12.

4. Духовність i бізнес. Чи можливе поєднання? Зовнішньоекономічний кур'єр. Львів, 2016. Січень-лютий. С. 21. URL: http://lcci.com.ua/wp-content/uploads/2014/03/ZK-1-2016-web.pdf.

5. Жуковський В. Журнал «Християнин і світ»: мета і завдання. Християнин і світ. Львів, 2009. № 1. С. 3.

6. Кащук О. Августин та папа Григорій Великий про праведне і неправедне володіння земними благами. Християнин і світ. Львів, 2009. № 1. С. 32-33.

7. Компендіум соціальної доктрини Церкви. URL: http://www.vatican.va/roman_curia/pontifical_councils/justpeace/docume nts/rc_pc_justpeace_doc_20060526_compendio-dott-soc_uk.pdf.

8. Креденцер О. В. Інноваційність як важлива характеристика підприємницької поведінки менеджерів освітніх організацій. Актуальні проблеми розвитку організаційної та економічної психологї̈ в Україні. Тези I Всеукраїнського конгресу з організачійної та економічної психології (29 червня - 2 липня 2011 року, м. Кам'янець-Подільський). Київ, Кам'янець-Подільський, 2011. C. $140-141$.

9. Малахов Р. Г. Взаимосвязь этики и экономики: попытка формализации. Вестник Алтайской академии экономики и права. Барнаул, 2013. № 52. С. 15-8.

10. Незабитовська C. Цінності сучасного студентства. URL: http://nadoest.com/cinnosti-suchasnogo-studentstva.

11. Падовезе Л. Отці церкви IV-V століття про соціальноекономічний вимір життя християн. Християнин $і$ світ. Львів, 2009. № 1. C. 28-31.

12. Разин А. В. Этика. Москва, 2006. 624 с.

13. Сен А. Об этике и экономике. Москва, 1996. 159 с.

14. Соснін О. В., Воронкова В. Г., Постол О. Є. Сучасні міжнародні системи та глобальний розвиток (соціально-політичні, соціально-економічні, соціально-антропологічні виміри). URL: http://pidruchniki.com/74058/politologiya/suchasni_mizhnarodni_sistemi _ta_globalniy_rozvitok. 
15. Химчук О. Цінності сучасної молоді. URL: http:// www.osvitata.com/osvita-ta-religiya/tsinnosti-suchasno-molodi.html.

16. Хома М. Біблійне розуміння багатства, або як християнам ставитися до матеріальних благ? Християнин $і$ світ. Львів, 2009. № 1. С. 4-15.

Information about the author: Petinova O. B.

Doctor of Philosophy, Professor at the Department of Philosophy, Sociology and Management of Socio-Cultural Activity, State Institution «South Ukrainian National Pedagogical University named after K. D. Ushynsky» 26, Staroportofrankovskaya str., Odesa, 65000, Ukraine 


\section{GLOBALIZATION - A CHALLENGE FOR MODERN EDUCATION}

\section{Poluiaktova O. V.}

\section{INTRODUCTION}

In the last quarter of the XX -the early XXI century, there has been economic, social and political, cultural development under the growing impact of globalisation. Its economic component is primarily related to sources, factors, forms of economic progress. Globalisation of the world economy has led to the fact that fierce global competition requires constant innovation, new ideas, and high-quality products. The world economy enters a new phase based on information technologies that do not demand large investments in the development of traditional infrastructure. The focus is shifted on connection and communication, and as a consequence the role of intellectual capital, not of tangible, is raised. It is formed mainly by knowledge and information.

Modern development of economics requires fast social-political and technological changes based on scholarly knowledge. Today, knowledge is the main source for achieving high social and economic results. First of all, knowledge is thoughts and experience, approaches and ideas regarding how production should be organised, what product should be like in order to meet all increasing human demands etc. The knowledge is manifested in the skills and abilities of people and is consolidated in the form of organizational culture, brands, patents, licenses, organizational structures, methods of interaction between enterprises and institutions.

Is the education sector able to recognise its extent of liability in searching for methods of training of competitive experts? How, in what way should education develop in the future, what are its strategic priorities and values?

In the context of dynamic changes of external and internal environment, the architecture of higher education is complicated and needs extreme, recombination and modification innovation aimed at obtaining or keeping leader position by higher education institution, reaching competitiveness at the market of educational services, management efficiency, meeting demands of receivers of educational 
services ${ }^{1}$. Education should get ahead of life. This is a fundamental truth that has been confirmed for a long time.

The era of technological revolution is primarily about the development of the mental functions of the employee, increasing of his or her relative share of creative intellectual origin, the ability to perceive information, process it, acquire new knowledge improving production on this basis, manage complex technological cycles.

In all developed countries, the factors of economic growth have changed and the role of research activities in production has sharply risen, and scientific areas have taken the centerpiece in economics. The main value of modern society is highly qualified experts who effectively use their intellectual potential to generate new ideas. The fundamental changes in the technical and technological basis of production require adequate changes in the professional and qualification structure of the workforce. New spheres of work have emerged, and vocational training of employees has been a decisive factor in economic growth. Malfunctions due to lack of skills can lead to excessive charges or accidents. All of these things objectively led to an increased focus on education and highly educated people as the main force not only of production but of the entire social life.

A source of acceleration of economic development that can provide immediate output in case of competent use is the growth of intellectual capacity. Challenges of countries are to change the model of socioeconomic development from monetary approach and extensive exploitation of human and natural resources to effective use of science and innovation. This is especially important taking into account the intellectual potential, global trends and processes of the intellectualisation of work and socio-economic life in general, the nature and speed of which form a new look to the world model and place of individual states in it.

\section{Education as a factor of economic growth in the context of globalization}

There are two main approaches to the periodisation of economic globalization. According to the first approach, globalization dated even before the Age of Discovery. The second approach is based on the fact

1 Ямков В. Ранжування університетів крок до відкритості та прозорості вищої освіти. Освіта Украӥни. 2007. № 42. 
that globalization is peculiar exclusively to the economic growth of the late XXth century. At this point in history, globalization is a driver of both national and international development and evolves into the dominant trend in world economic processes ${ }^{2}$.

The process of globalization is in progress under the influence of a set of factors. Among them are scientific and technological progress, a revolution in information technology; development of international infrastructure, new generations of transport and communications; extension of the international division of labour, further development of the internationalization of production; descent of the role of traditions, social ties and customs, internationalization of education, cultural space etc.

At the same time, globalization has a contradictory impact on both individual states and the world economy as a whole. On the one hand, it opens up previously unprecedented economic growth opportunities driven by accelerating the process of dissemination of advanced technologies, development of creativity and innovations; improving the mechanism for allocating resources, improving the efficiency of their use based on the development of global competition; enhancing the quality of life, improving the welfare of families, expanding multi-options and access to new ideas and knowledge; strengthening international coordination, reducing the threat of international conflicts, local wars; the spread of ideas of humanism, democracy, protection of civil rights and fundamental human freedoms.

Economic globalization also generates unprecedented threats and risks as a result of intensification of inequality of socio-economic development of countries on the global scale; amplification of imbalances in the world economy, increase of the gap between the commodity and financial markets, the threats of global crises; growing conflicts of different nature and scale, creation of a global network of criminal business, international terrorism; loss of national identity, extension of uniform standards to national cultures; exacerbation of global problems ${ }^{3}$.

In general, globalization is a complex, multifaceted process that covers all aspects of social development and is realised in the growing

2 Філіпенко А.С. Глобальні форми економічного розвитку: історія і сучасність. К.: Знання, 2007.670 с.

${ }^{3}$ Мочерний С. В. Основи економічних знань. Київ, 1996. 405 с. 
interdependence of the countries across the world as a result of the formation of a single world economic organism.

Today, analysis of the global trends that emerged in the XX century is of a special topicality and significance; they can run and run in the current century, thus challenging human civilization. The challenge directly concerns the education sector aimed at adjusting its priorities and values, taking into account not only currently important but also perspective, long-term demands of both human being and society ${ }^{4}$.

The new paradigm of economic development based on knowledge and information technologies erases the national boundaries of competition, objectively promotes the intellectual and educational potential of the country as a key resource for economic growth. Therefore, in the present context, the only educational system that takes into account the processes of globalization can provide a successful career.

Globalization is perhaps the greatest fundamental challenge to education. The world we live in is significantly changing, becoming more volatile and unpredictable. VUCA world is a frozen term, people live and work inside uncertainty (VUCA is an acronym of the English words: volatility, uncertainty, complexity i ambiguity) ${ }^{5}$. What an expert should be not only over the next while but also in modern society to be competitive, successful, in demand in the labour market - these issues are now very popular among the most burning issues.

Adam Smith wrote that "increase in productivity of useful work depends first and foremost on improving the skill and ability of the worker and then on improving the machines and tools he used"

D. Ricardo explained countries' lag in economic development, among other reasons, by "lack of education in all population strata" .

H. de Saint-Simon expressed the important statement that in the future, technical and scientific knowledge would become especially significant, and "the steady aim of the public organization would be better application of the knowledge gained by the sciences, arts and crafts,

${ }^{4}$ Гершунский Б. С. Философия образования для XXI века (В поисках практикоориентированных образовательных концепций). Москва, 1997. 697 с.

5 Менеджмент підприємницької діяльності: навч. посіб. для професійної підготовки військовослужбовців ЗС України звільнених у запас. Проект «УкраїнаНорвегія». Вип. 6, Одеса: Видавничий дім «Гельветика». 2018. 240 с.

6 Смит А. Исследование о природе и причинах богатства народов. Москва: Соцэкгиз, 1956. $490 \mathrm{c}$.

${ }^{7}$ Рикардо Д. Сочинения. Москва, 1995. Т. 1. 365 с. 
amplification of the knowledge, its improvement and more accumulation". J. Mill as well as his predecessor was a follower of the development of industrial society. In his opinion, deficiencies can be eliminated only when the degree of freedom of all members of society increases that is considered to be the most important condition for social progress ${ }^{8}$.

Human activity is increasingly acquiring spiritual dimension. Physical work stands down mental one. It is not the "salariat" (hired workers) but the "cognitariat" - scientists, engineers, experts are quite independent due to their intelligence level - they become leaders of society and creators of technological innovations ${ }^{9}$.

In 1962 F. Machlup introduced the term "intellectual worker" for scientific use where he emphasized previously unknown characteristics of a new type of employee: his/her orientation and handling of information and knowledge; high mobility and drive for an activity that opens the space for self-realization and self-expression, even to the detriment of instant financial benefit. In this context, there are interesting reflections of academician V. Semynozhenko regarding the humanitarian-innovation revolution. "An individual has become not the abstract value but the basis for all kinds of politics and first of all, the main object of investment and the main carrier of economic profits"

Thus, there is a graduation in views regarding the objective processes of development of productive forces, when the role and importance of his/her educational level, qualification, intelligence, competence, scientific knowledge unprecedentedly grow up in the economics of the human person.

Modern society, as never before, needs a creative person focused on innovation, initiatives. Only such a person - the carrier of intellectual potential - is able to develop his/her abilities, talents and endowments; his/her activity can provide a qualitatively new state of society the achievement of which is our strategic goal. Increase of the role of intellectual potential at the present stage is a fitting result of progressive development.

8 Иноземцев В. Л. К теории постэкономической общественной формации. Москва: Таурус, 1995. 302 с.

9 Хорос В. Постиндустриальный мир - надежды и опасения (к постановке проблемы). Москва: МЭ и МО. 1998. № 12.

10 Злупко С. М., Радецький Й. І. Людський потенціал, зайнятість і соціальний захист населення в Україні: Навчальний посібник. Львів: Видавничий центр ЛНУ імені Івана Франка, 2001. 192 с. 
There are great expectations from the youth, its energy and inquiring mind, interest in everything new. In this regard, the responsibility and role of education are increasing which greatly influences the choice of each of their future activities and the formation of the intellectual potential of society. Education and professional training is a multifunctional system with a complex structure. The impact of the system on the life of society is quite wide: in the preschools establishments and general school, the process of formation of a person, individual and social consciousness of the person begins, which also continues in the system of professional training. Nowadays, the role of the education system as an institute of spiritual education of a person, enrichment of its human capital assets, improvement of his/her qualities as a subject of industrial relations is increasing. The above activity of educational institutions acting as a kind of realization of the demand of the state and citizens for educational services needs special support of the state.

The system of education and professional training as an institute of spiritual production, professional and intellectual development of a person, development of his/her creative potential should form such a set of knowledge and skills of the society which could ensure their expedient activity in the system of social division of labour.

Today, any kind of education (general, professional) should provide not only the body of knowledge, not only train experts for a certain type of activity but also contribute to their need to beef up the previously acquired knowledge and skills, broaden their outlook, enhance culture, develop abilities, improve their profession, acquire a new profession. At the moment, one of the main tasks is to determine the degree of training of experts of different areas of expertise in advance. Besides, at the modern stage of development, it is important to organize a qualified and effective form of continuous training and mainly independent training of all employees.

"The future does not belong to those who provide cheap work or have ordinary capital - they will be replaced by automation. Those who are ready to implement innovations and create new products, services and business models will be into luck", Erik Brynjolfsson, Andrew McAfee and Michael Spence believe ${ }^{11}$.

${ }^{11}$ Brynjolfsson E., McAfee A., Spence M. New World Order. Labor, Capital, and Ideas in the Power Law Economy. Foreign Affairs. 2014. № 4, July - Aug. P. 19. 
Sociologist V. I. Ihnatiev gives the following facts: information volume annually increases by $30 \%$, the volume of digital information doubles every 18 months ${ }^{12}$. According to the statement of Executive Chairman of Alphabet's Board, Google parent's company, Eric Schmidt, every two days we create as much information as we did from the date of civilization origin until $2003^{13}$. The number of research increases by $7-9 \%$ a year that equals to doubling scientific productivity every ten years, to put it in crude terms ${ }^{14}$.

University graduates will have to live and work in a new world where the boundaries of national economies become more conditional. In modern conditions, education "product" is an expert - competent, intelligent, skilful, cultural and humane. Thus, competition in the education sector is first and foremost an impetus for deeper cooperation. The need to create a single market for a highly skilled workforce has caused the need for integration in higher education, which is intended to promote the development of the market of high-quality educational services, enhance academic, professional and social mobility of participants of the educational process.

The education sector certainly has the most direct relevance to all events in the world. It is education and only education is able to reverse the catastrophically growing negative tendencies in human life ${ }^{15}$. The challenge of the XXI century addressed the education sector is to awaken the functions of education as the most important sphere of cognition, the formation of correction and transformation of the mentality of the individual and society as a whole.

Today, the educational system has taken a special position in the system of social institutions typical of a post-industrial developing society and forming intelligence society.

The economic dynamics of industrially developed countries linked to the intensification of competition, the rapid change of technology and

12 Игнатьев В. И. Социология информационного общества: учеб. пособник. Новосибирск: Изд-во НГТУ, 2017. 356 с.

${ }^{13}$ Sigler M. G. Eric Schmidt: Every 2 Days We Create As Much Information As We Did Up To 2003. URL:http://techcrunch.com/ 2010/08/04/schmidt-data (дата звернення 25.05.2019)

${ }_{14}$ Фейдл Ч., Бялик М., Триллинг Б. Четырёхмерное образование: компетенции, которые нужны для успеха. URL: http://nios.ru/sites/nios.ru/files/poleznoe/4D_ Education_0.pdf (дата звернення 20.04.2019)

${ }^{15}$ Гершунский Б. С. Философия образования для XXI века (В поисках практикоориентированных образовательных концепций). М., 1997. - 697 с. 
enhancement of economic uncertainty creates a demand for new types of competencies and new forms of human resource training. On the one hand, there is a growing demand for employees with maximum flexibility and a high degree of creativity, who are ready for independent actions and teamwork, able to work in different cultures and with different technological environments. On the other hand, there is a demand for employees who will work with a limited scope of tasks for a particular workplace. From a third perspective, there is a growing need for employees who are ready for thorough lifelong learning that will allow providing ongoing training for staff following a constantly changing range of tasks.

Psychologist Herbert Gerjuoy from the Human Resources Research Organization gives a simple formulation: "New education should teach the individual how to classify and reclassify information, how to evaluate its validity, how to change categories if necessary, how to turn from specific to abstract, and vice versa, how to look at problems under a new perspective, how to engage in self-education. The person who cannot read will be not illiterate in the future, but the one who has not learned to study". According to A.Toffler "people who will live in the superindustrial society need new skills and knowledge in three key spheres: study ability, communication ability and choice ability ${ }^{16}$. The paper notes that the Report of the International Commission on Education for the Twenty-first Century "Education: hidden treasure" also marks and highlights the importance of four basic principles compiling modern education - learning to live, learning to know, learning to do and learning to live with others ${ }^{17}$. According to Aristotle "the human beings naturally follow knowledge", and Cicero wrote "So great is our innate love of learning and of knowledge that no one can doubt that man's nature is strongly attracted to these things even without the lure of any profit" ${ }^{\text {"18. }}$. What do you need to know, to learn, to develop to be competitive in the modern labour market? Majority of education innovators answers that it is important to develop so-called "hard skills" and "soft skills" or

${ }^{16}$ Тоффлер Э. Шок будущего: Пер. с англ. Москва: ООО «Издательство АСТ», $2002.557 \mathrm{c}$.

${ }^{17}$ Образование: сокрытое сокровище (Learning: The Treasure Within). Основные положения Доклада Международной комиссии по образованию для XXI века. MOO ВПП ЮНЕСКО «Информация для всех», 2007 г. URL:www.unesco.org. (дата звернення 12.04.2019)

18 Аристотель. Сочинения в четырех томах. Т. 1. Ред. В. Ф. Асмус. Москва: Мысль, 1976. 550 с. 
"flexible skills". Results of the research undertaken at Harvard University and Stanford Research Institute indicate that the contribution of "hard skills" to the employee's professional success is only $15 \%$, while the soft determine the rest $-85 \%^{19}$. Another research conducted by Stanford Research Institute in cooperation with Carnegie Melon Foundation among CEOs of companies enlisted in "Fortune 500" shows that that long-term and stable success of companies' executives is determined by soft skills by $75 \%$ and by hard skills only by $25 \%$.

The application of soft skills means the ability to use different behaviour models in one situation, fully understand own and others' interests, prioritize in the here and now, decide between alternatives.

Modern society is very interested in the fact that each person makes own individual contribution to the development, renewal of all life spheres. An urgent task of modern education is to reveal the creative possibilities of employees, our personnel, highly educated, professionally trained experts to the full.

The prerequisite for globalization processes is the review and refashioning of the system of international relations in terms of human values, joining efforts and resources of humanity on the basis of an awareness of unity of interests and shared responsibility to future generations.

\section{Mechanism of the functioning of modern markets of educational services}

According to the research of foreign scientists, technologic core involves Japan, USA, Canada, South Korea, and Australia. Organization of innovation activities in the leading countries has the following features: horizontal integration of $\mathrm{R} \& \mathrm{D}$, designing and training, creation of computer networks, joint research, state support for new technologies. The leaders of the advanced countries have discovered that the knowledge, the intellectual resource of the state becomes a decisive factor of development not in the distant future, but today.

At the end of the XXth century, such a branch of the world national economy as the market of educational services was formed. The key

19 Иванов Д. В. Путь к вершине. Факторы успеха. Управление развитием персонала. 2010. URL: https://grebennikon.ru/ author-3753.html (дата звернення 20.04.2019) 
parameters of the market are determined by such indicators as sales volume accounting to tens of billions of US dollars, as well as the international flow of migration, which has academic nature, totalling several million people a year. In 2002 the international market of educational services accounted for almost 3\% of the global services market. In 2013 US revenues driven by the education of international students were nearly 10.29 billion dollars. This figure is higher than the state's funding for higher education in all Latin American countries.

The global education services market increases the number of virtual universities, which accounted for approximately 1180 units in 2015. It is envisaged that as early as 2020, the number of students at such kind of universities may be larger than the number of full-time students ${ }^{20}$.

At the beginning of the XXI century, the competition between exporting countries of education services has significantly increased. For example, such countries as the United Kingdom, Japan, Australia and France have adopted programs that provide the same level as the United States in years ahead. Approximately 500 thousand foreign students study in the mentioned countries every year. And their total tuition is about $\$ 13$ billion.

In the XXI century, in the context of globalization, the educational market is opened within the concept of transnationalization of education. The concept opens up tremendous prospects in the provision of education services to most age groups, that is, to the economically active population. For this reason, information technology is used $^{21}$. The concept of transnationalization of education defines, above all, the range of such educational services that can be provided through a variety of education programs: online or remotely as well as the establishment of branch units. It is also provided for the integration of training programs, singing of partnership agreements between educational institutions located in different countries for the implementation of joint programs ${ }^{22}$.

${ }^{20}$ Бахманов А. Общества знания - светлое будущее всего человечества. Реферат доклада ЮНЕСКО «К обществам знания». URL: http://subscribe.ru/archive/ (дата звернення 20.05.2019)

21 Доклад о развитии человека 2016. Опубликовано для Программы развития OОН (ПРООН). М.: Весь мир, 2016.Доклад о развитии человека 2016. URL: www.vesmirbooks.ru (дата звернення 22.05.2019)

${ }^{22}$ Глен Р.Дж. Как перебросить мост от сложных проблем транснационального образования к аккредитации. Высшее образование в Европе. 2015. T. XXVI. № 1. 
In the current conditions of globalization of the education system, assessment of the capacity of the global education services is quantitatively presented in UNESCO Report "To the knowledge society". Between 1970 and 1990, the number of university students increased from 28 million to 69 million, more than double, all over the world. As of 2002, there were 122 million students worldwide. According to the latest data, in 2016 the number of students is 150 million $^{23}$.

The main features and characteristics of the international education services market are the export of education services and education mobility.

The characteristics can be analysed and assessed relying on the data on international students' number studying in different countries. Study of international students in different countries is an important indicator of the integration level of the domestic education system into the world environment. As for education services export, today, there is its clear differentiation into 2 types: active export and passive export. Passive export has a long history and is related to student education in different countries of the world. Active export is characterized by foreign expansion of higher education institutions, that is, in other countries, branches of education institutions are created in terms of transnational corporations.

At the international level, China ranks first in the number of international students with specific gravity $67 \%$ of the overall number of students in the country. European countries are lower: Switzerland $18 \%$, Austria $-14 \%$, Belgium - 11\%, the United Kingdom, France, Germany $-10 \%$, Denmark $-9 \%$. And $18 \%$ and $10 \%$ of international students study in Australia and New Zealand.

Analyzing the structure of foreign students by home country, the paper concludes that in Africa, the largest share of students are African-born 73.0\%. In North America, higher education institutions were in demand by the population of the Americas $-33.6 \%$ and $23.4 \%$ respectively.

At the same time, higher education institutions in the United States of America are in high demand among European students - 62.5\%. And the vast majority of students in Canadian universities are students from Europe $-36 \%$ and $23.9 \%$ from Asia $^{24}$.

${ }^{23}$ Source 21.

24 Система образования в Дании - стране, практически всеобщей гармонии. URL: http://www. aboutstudy.ru/ (дата звернення 22.04.2019) 
Effective competition for resources of foreign students can take place under the purposeful state policy. Thus, since the last century, integral actors of the global market of education services have been specialized organisations which are functioning in many countries and deal with the attraction of foreign citizens to study in the country. They consist of national agencies; education funds; information centers and international exchange centers; different associations, councils, etc. ${ }^{25}$. Increased competition in different areas is an integral factor in globalization and characterizes the current development of the world education market.

Multiplication of universities in developing countries has become an important trend in recent decades. There is a significant increase in higher education institutions in the countries of Africa, Asia and Latin America. Despite the growing number of higher education institutions, it is still difficult for developing countries to compete with universities of developed countries. This situation happens primarily because higher education institutions of the countries mainly provide diploma programs rather than postgraduate education programs ${ }^{26}$.

The limited supply of postgraduate programs in developing countries explains another important trend in the development of the world education services market, that is, the distribution of foreign students through study programs in developed countries. Recently, the majority of fresh students have chosen MA and postgraduate training programs. Consequently, in the United States in 2016/17 academic year, 46.3\% of newly arrived foreign students applied for postgraduate programs (master's and postgraduate programs) and $40.5 \%$ chose to study under the major higher education programs (bachelor degree course) ${ }^{27}$.

Over the last 15 years, new leaders have emerged in the world market of education services. Australia made a serious step up. According to forecasts, the demand for Australian higher education will be 280848 people by 2025 .

The state regulation of the education services market is carried out for effective functioning, stimulation of the process of institutions'

${ }^{25}$ Айдрус И.А., Филиппов В.М. Мировой рынок образовательных услуг: Учеб. пособие. Москва: РУДН, 2017. 194 с.

${ }^{26}$ Глен Р.Дж. Как перебросить мост от сложных проблем транснационального образования к аккредитации. Высшее образование в Европе. 2015. T. XXVI. № 1.

${ }^{27}$ Source 24. 
establishment, ensuring national interests of producers and consumers of education services. Regulatory bodies include the ministry of education, services and agencies composing them. The ministries of education are entrusted with the functions of drafting and adopting legal acts, their implementation, realising public policy in the education sector as well as control over the activities of organizations composing their part ${ }^{28}$.

As the United States holds the leading position upon many indicators, it is expedient to consider the experience of the functioning of the education services market in the United States rather than anywhere else. The USA is characterized by a rather diversified structure stimulating the country's progress in the global education services market. The US Councils for International Education, the Association of International Educators, the Institute for International Education, the International Council for Research and Exchanges, and many other specialized organizations and foundations are engaged in promoting US education and attracting students from around the world. Thus, Education USA is a network of over 425 councils supported by the Bureau of Educational and Cultural Affairs and U.S. Department of State. The network promotes U.S. higher education abroad by offering accurate, current information about opportunities to study in the United States and guidance how best to gain access to the opportunities.

One of its internal activities is to inform U.S. universities on the importance of enrolling international students, on international education policy, on global education systems, and on how to maintain a welcoming atmosphere for international students ${ }^{29}$. Education funding is one of the most burning issues facing national governments and international organizations. The purpose of educational grants is to reduce student education expenditures. Grants are provided free of charge by the state, private companies, banks, charities etc. Different countries use various grant principles ${ }^{30}$.

Recently, education loan schemes have been promoting, in particular by finance office. There are similar schemes in almost 50 countries. In the USA, financial aid to students is rendered through such federal education loans as Stafford, PLUS, the Ford Direct Student Loan Program.

${ }^{28}$ Source 24.

${ }^{29}$ Source 25.

30 Айдрус И.А., Филиппов В.М. Мировой рынок образовательных услуг: Учеб. пособие. Москва: РУДН, 2017. 194 с. 
American students have the opportunity to receive financial aid for study abroad. Aid for international students is provided by some federal education programs such as Global UGRAD in Eurasia and Central Asia; the Edmund S. Muskie Fellowship Program (MUSKIE); the Hubert H. Humphrey Fellowship Program provides the opportunity to visit the USA to conduct research and enrich professionalism; Fulbright programs provide Graduate and Postgraduate Scholarships; "Opportunity Initiative", scholarships program supported by the U.S. Embassy, grants talented students who can receive financial assistance from U.S. universities covering a large portion of their tuition $\operatorname{costs}^{31}$.

\section{CONCLUSIONS}

In the context of globalization, the internationalization of economy gains new features: the global world production is formed based on intensification of activity of multinational corporations; the growth rate of international trade is ahead of the growth rate of production; the orientation and structure of international trade is changing, and exchange of science-based, high-tech products between developed countries is increasing; the orientation of developed economies on the activation of the human factor, the ability to generate new knowledge, to apply it quickly using modern methods of information processing is increasing; the search for a global center of management and tools for regulating global economic processes is intensifying.

The complex and contradictory processes of globalization, which have taken place in the world, are also reflected in the education sector. First of all, this concerns such issues as strategies for the development of international relations between higher education institutions; international education quality assurance, training of competitive experts; transnational education; information and communication technologies of education, establishment of virtual universities, introduction of non-traditional technologies of intensive learning; ensuring equality and access to higher education; the problem of migration of domestic intellectuals to the countries of industrial-information technologies.

It is necessary to find ways of convergence and gradual integration of different philosophical doctrines of education as the most important

31 Айдрус И.А., Филиппов В.М. Мировой рынок образовательных услуг: Учеб. пособие. Москва: РУДН, 2017. 194 с. 
condition for the formation of a unified world educational space, recognition of universal education and pedagogic ideal and values. These common challenges have clear interdisciplinary nature and are the subject of study of various sciences. The study of education as a sphere of formation of a man of the era is a topical and cognitive problem. The choice of the only right path is possible based on the consideration of people's interests and needs. The time of choice is today. It is impossible without comprehensive activation of the intellectual, spiritual potential of society, the growth of the general and political culture of the people. It is necessary for the vast majority of people living on the earth to develop general principles of life arrangements, to recover systematic and scientific nature to the foreign policy of the states. This is the ideological foundation of globalization.

\section{SUMMARY}

The paper studies key points of globalization as a socio-economic process. It analyses the positive and negative impact of the phenomenon on economic process. The author considers the interconnection of knowledge and progressive socio-economic development. The research covers the growing role of education, which is a condition for activation and increase of intellectual potential. It is noted that the only complex transformation and involvement of such powerful drivers of modern progress as science and the human factor can create something new that will make speed-up process stable and strong. The author analyses the mechanism of the functioning of modern markets of education services. It is presented recommendations on the promotion of competitiveness of future experts in the open market environment.

\section{REFERENCES}

1. Ямков В. Ранжування університетів крок до відкритості та прозорості вищої освіти. Освіта України. 2007. № 42.

2. Філіпенко А.С. Глобальні форми економічного розвитку: історія і сучасність. Київ: Знання, 2007. 670 с.

3. Мочерний С.В. Основи економічних знань. Київ: 1996. 405 с.

4. Гершунский Б.С. Философия образования для XXI века (В поисках практико-ориентированных образовательных концепций). М., 1997. 697 с. 
5. Менеджмент підприємницької діяльності: навч. посіб. для професійної підготовки військовослужбовців ЗС України, звільнених у запас. Вип. 6, Одеса: Видавничий дім «Гельветика». 2018. $240 \mathrm{c}$.

6. Смит А. Исследование о природе и причинах богатства народов. Москва: Соцэкгиз, 1956. 490 с.

7. Рикардо Д. Сочинения. М., 1995. Т. 1.365 с.

8. Иноземцев В. Л. К теории постэкономической общественной формации. Москва: Таурус, 1995. 302 с.

9. Хорос В. Постиндустриальный мир - надежды и опасения (к постановке проблемы).Москва: МЭ и МО. 1998. № 12.

10. Злупко С.М., Радецький Й.І. Людський потенціал, зайнятість i соціальний захист населення в Україні: Навчальний посібник. Львів: Видавничий центр ЛНУ імені Івана Франка, 2001. 192 с.

11. Brynjolfsson E., McAfee A., Spence M. New World Order. Labor, Capital, and Ideas in the Power Law Economy. Foreign Affairs. 2014. № 4, July - Aug. P. 19.

12. Игнатьев В.И. Социология информационного общества: учеб. посіб. Новосибирск: Изд-во НГТУ, 2017. 356 с.

13. Sigler M.G. Eric Schmidt: Every 2 Days We Create As Much Information As We Did Up To 2003. URL: http://techcrunch.com/ 2010/08/04/schmidt-data (дата звернення 25.05.2019)

14. Фейдл Ч., Бялик М., Триллинг Б. Четырёхмерное образование: компетенции, которые нужны для успеха. URL: http://nios.ru/sites/nios.ru/files/poleznoe/4D_Education_0.pdf (дата звернення 20.04.2019)

15. Гершунский Б.С. Философия образования для XXI века (В поисках практико-ориентированных образовательных концепций). Москва, 1997. 697 с.

16. Тоффлер Э. Шок будущего: Пер. с англ. М.: ООО «Издательство АСТ», 2002. 557 с.

17. Образование: сокрытое сокровище (Learning: The Treasure Within). Основные положения Доклада Международной комиссии по образованию для XXI века. МОО ВПП ЮНЕСКО «Информация для всех», 2007 г. URL:Www.unesco.org. (дата звернення 12.04.2019)

18. Аристотель. Сочинения в четырех томах. Т. 1. Ред. В. Ф. Асмус. Москва: Мысль, 1976. 550 с. 
19. Иванов Д.В. Путь к вершине. Факторы успеха. Управление развитием персонала. 2010. URL: https://grebennikon.ru/author3753.html (дата звернення 20.04.2019)

20. Бахманов А. Общества знания - светлое будущее всего человечества. Реферат доклада ЮНЕСКО «К обществам знания». URL: http://subscribe.ru/archive/ (дата звернення 20.05.2019)

21. Доклад о развитии человека 2016. Опубликовано для Программы развития ООН (ПРООН). М.: Весь мир, 2016. Доклад о развитии человека 2016. URL: www.vesmirbooks.ru (дата звернення 22.05.2019)

22.Глен Р.Дж. Как перебросить мост от сложных проблем транснационального образования к аккредитации. Высшее образование в Европе. 2015. Т. XXVI. № 1.

23. Система образования в Дании - стране, практически всеобщей гармонии. URL: http://www.aboutstudy.ru/ (дата звернення 22.04.2019)

24. Айдрус И.А., Филиппов В.М. Мировой рынок образовательных услуг: Учеб. пособие. М.: РУДН, 2017. 194 с.

25. Глен Р.Дж. Как перебросить мост от сложных проблем транснационального образования к аккредитации. Высшее образование в Европе. 2015. Т. XXVI. № 1.

26. Айдрус И.А., Филиппов В.М. Мировой рынок образовательных услуг: Учеб. пособие. Москва: РУДН, 2017. 194 с.

\section{Information about the author: Poluiaktova O. V. $\mathrm{PhD}$ in Economics,}

Senior Lecturer at the Department of Political Sciences and Law, State Institution «South Ukrainian National Pedagogical University named after K. D. Ushynsky» 26, Staroportofrankovskaya str., Odesa, 65000, Ukraine 


\section{FUNDAMENTALS OF THE THEORY OF INFORMATION WAR}

\section{Pronoza I. I.}

\section{INTRODUCTION}

In today's global context of integration and fierce international competition, the information space is central to the collision and struggle of diverse national interests.

New information technologies make it possible to achieve the realization and functioning of state interests without the use of military methods, to weaken, weaken or even destroy a competing state, without using forceful means, only under conditions, without awareness of the real and potential threats of negative information influences and formation of this country and the proper functioning of an effective defense and response system to these challenges and threats.

Concepts such as: information society, information infrastructure, information space, and information resources - sufficiently define a certain state, level and course of socio-political, socio-economic, scientific and technical and cultural course of the state ${ }^{1}$.

The information society also gave birth to its wars - information wars. All previous wars considered had a completely different character. The new concept of information warfare involves replacing the principle of mass destruction with the principle of neutralizing the enemy's army by destroying (isolating, falsifying) critical information, rather than simply by improving the method of warfare.

In the conditions of formation of information society, development and domination of information technologies, the term "information war" not only became a symbolic symbolic unit of journalistic and political vocabulary, but also began to be actively used as an independent category in the scientific discourse.

The modern 21 st century is increasingly called the "information technology era", in which there is a tremendous contribution to the

${ }^{1}$ Проноза I. I. Інформаційна безпека держави: сутність та основні визначення. Гілея: науковий вісник. Збірник наукових пращь. 2017. № 127(12). С. 345-349. 
development of methods of warfare, as well as the fight against information warfare, in which information security has become almost a panacea for solving problems of the information society. The definition of a modern information society is equivalent to the concept of "postindustrial society", given the increasing political, social and military importance of information confrontation of states, as well as the huge investment in research centers. And a number of post-industrial states attach tremendous importance to the development of their country's science, technology and information security, being well aware of the importance of the impact of the media on the mass consciousness, both regionally and internationally ${ }^{2}$.

Information warfare now pervades all forms of struggle, ranging from diplomatic and economic to armed struggle, developing as an independent sphere of activity. The rapid development of information technology has led to the shifting of conflicts from the traditional physical space into a fundamentally different one - cyberspace. Today, everyday political practices provide many examples of waging a wide variety of information wars, both in democratic states and in transitional political systems.

Ukraine is facing the threat of large-scale actions of the information war, which are aimed at its information resources, the system of decisionmaking by public authorities, as well as the mass consciousness of the population. Thus, recently the amount of negative information about Ukraine has increased significantly in the world information space. This information is not random but purposeful, created and provided in a specific scenario. The purpose of such information is to manipulate public opinion of Ukrainians.

A characteristic feature of the Ukrainian information space was the presence of internal political wars: information wars between oligarchs, between the authorities and the opposition, as well as staged confrontations between different segments of government.

Thus, the study of the essence of information wars, both external and internal, their basic methods, means, patterns becomes one of the most relevant areas of

2 Аюрова А. М. Информационная война как феномен информационного общества. Экспериментальные и теоретические исследования в современной науке : сб. ст. по матер. II междунар. науч.-практ. конф. № 2(2). Новосибирск, 2017. С. 67-76. 
scientific research of domestic political science, as it is necessary to effectively counteract the threats to the information and psychological security of the individual, society and state and ensuring the security of Ukraine as a whole.

Among the scientists involved in the study of information wars we can distinguish the following: D. Volkogonov, S. Grinyayev, O. Kolinovsky, A. Krutskikh, A. Fedorov, M. Pavlyutenkova, V. Petrov, I. Rabinovich, I. Sharavov, D. Feldman, G. Pocheptsov, G. Karpenko, V. Lipkan, V. Ostroukhov and others. However, they explored only certain aspects of information wars.

\section{Theoretical analysis of the definition of "information war"}

The essence and role of information warfare is devoted to a large number of publications in which it is interpreted in different ways.

Prominent researchers Zinoviev AA, Dugin AG, Korovin VM say that a new global war is already underway. It is not officially announced and is hidden from the eyes of ordinary citizens, but it is leading humanity to profound changes in the deployment of forces on the world stage. The phenomenon of the described hidden war became possible only in the conditions of development of modern information and communication technologies. The analysis of world experience shows that today direct aggression has ceased to be the only means of domination. In this regard, modern science is gradually focusing on the study of indirect forms of confrontation, with particular attention to information wars.

The term "information war" itself is now more non-fiction and has not yet been recognized. Continuous discussions about what is really covered by this concept, as well as disputes about the correctness and practical applicability of this term to the sphere of social relations, which is called information conflict or conflict of interest in the information sphere of social systems, testify to this. Thus, a separate scientific problem is the development and coordination of scientific and terminological apparatus ${ }^{3}$.

In domestic and foreign science there are many different and often mutually exclusive approaches to identifying conflicts that take place in

${ }^{3}$ Проноза I. І. Інформаційна війна: сутність та особливості прояву. Актуальні проблеми політики. Збірник наукових пращъ. 2018. № 81. С. 79. 
the modern information space. Such diversity and inconsistency is a serious obstacle to the development of information war theory.

It is appropriate to analyze the definitions of the information war contained in the papers of foreign experts as well as in official documents. They can be grouped as follows: definitions of information warfare in a narrow sense, ie those that reflect a purely military orientation, and definitions in a broad sense, which reflect a focus on securing national interests in any vital sphere of state and public activity.

Information wars as a phenomenon have existed in one way or another since ancient times. Execution of information influences with the use of information weapons (concealment of information; its submission in part, in some perspective; exaggeration of the consequences) was recorded by chroniclers in the territory of Ukraine in Kievan Rus ${ }^{4}$.

For the first time the term "information warfare" was used by T. Ron in a report "Weapons Systems and the Information Warfare" prepared by him in 1976. He emphasized that information infrastructure is a key aspect of the US economy, and at the same time it is becoming a vulnerable target. in wartime and in peacetime.

According to Panarin I. N. the point of reference should be taken not in $1976^{5}$, but in 1967, when A. Dulles (the main organizer of the information war against the Soviet Union) published a book called "The Secret Capitulation", devoted to secret separate negotiations between the United States and Great Britain, on the one hand, and the Reichsführer of the SS. Himmler - on the other. It was first introduced the term "information war", which represents personal, intelligence, sabotage actions to undermine the rear of the enemy ${ }^{6}$. Later, the term became actively mentioned in the press, especially after the operation "Operation Desert Storm" in 1991.

Today, the concept of "information war" is defined differently. This is due to the ambiguity of the term "information warfare", which gave rise to many differences in its translations. This concept can be interpreted as "information war", "information confrontation", "information and psychological war". In particular, information warfare is characterized as

${ }^{4}$ Гуз А.М. Історія захисту інформації в Україні та провідних країнах світу : навчальний посібник. К, 2007. С. 18.

${ }^{5}$ Гриняев С. Концепция ведения информационной войны в некоторых странах мира. URL: http://www.soldiering.ru/psychology/conception_psywar.php

${ }^{6}$ Панарин И. Н. Информационная война и третий Рим. М, 2001. 244 с. 
information activity undertaken by political education (such as the state) to weaken or destroy other political entities; as an information fight between competitors; an information military conflict between two massive enemies, such as armies, etc ${ }^{7}$.

Information warfare is a total phenomenon where it is impossible to determine its beginning and end. In particular, according to S. Rastorguev ${ }^{8}$, information warfare is the existence of struggle between states with the help of information weapons, that is, open and hidden purposeful informational influences of systems (states) on each other, in order to gain advantage in the material sphere, where informational influences are influences by such means, the use of which allows to achieve the intended goals.

The results of the theoretical analysis make it possible to state that there are many argumentative concepts of information war and there is no generally accepted definition of this concept. This diversity of approaches is due, first of all, to the complexity of the object of study itself, as well as to the theoretical and methodological positions of the authors belonging to different scientific schools. This determines their focus on certain aspects of the issue.

Thus, within the psychological paradigm, information war is understood as the latent influence of information on the individual, group and mass consciousness through the methods of propaganda, misinformation, manipulation in order to form new views on the sociopolitical organization of society through the change of value orientations and basic attitudes.

Exploring the information war in the context of psychological theories, V. A. Lisichkin and L. A. Shelepin indicate that its object is the cognitive-emotional sphere of individuals, and the main goal is the management of intellectual-psychological and socio-cultural processes, which is a necessary element of which there is a lack of awareness of this influence by those who are prone to veiled influence and the following lines of programmed behavior'.

${ }^{7}$ Манойло А. В. Государственная информационная политика в особых условиях. M, 2013. C. 239.

${ }_{9}^{8}$ Расторгуев С. П. Философия информационной войны. М, 2003. С. 455-456.

9 Лисичкин В. А. Третья мировая (информационно-психологическая) война. URL: http://malchish.org/lib/politics/infwar.htm 
In his turn, V. Karpenko ${ }^{10}$, exploring the information space of the Ukrainian state, highlights information expansion of Russia, which, in order to spread neo-imperialist ideas, presents forms of Russian expansion in the information space of Ukraine, using Ukrainian mass media for its purposes.

The geopolitical approach is also noteworthy. According to the provisions of the geopolitical approach, information war is interpreted in the concepts of inter-state confrontation, aimed at solving foreign policy goals, not with the help of physical force, military equipment and weapons, but with the use of sophisticated technologies of coercive control, which has an external expression in the form of diplomacy.

An interesting refinement is the study of the information war I. A. Mikhalchenko in the context of modern geopolitical processes. The researcher defends the position according to which information war is defined as a holistic technology aimed at achieving humanitarian enslavement of one group of people by others. It is a product of postindustrial society and is conditioned by the impossibility of global armed conflicts that can destroy the planet ${ }^{11}$.

An advocate of such thinking is I. N. Panarin. According to the definition of political scientist, information warfare is "the dominant way of achieving power, the organization of the neosphere and the world of information and psychological space in their interests" ${ }^{12}$. In his view, modern statesmen must not only have and possess a

powerful resource and credit of public trust, but also be able to wage effective information confrontation. It is this that enables successful politicians to increase their political capital.

In modern scientific research the circle of scientists who focus their attention on the social-communicative aspect of information wars is distinguished. Their methodological principles of study differ in that the subject field is dominated by information, which becomes dominant in the sms of reality and forms cognitive orientations, not consciousness of people.

${ }^{10}$ Карпенко В. Інформаційний простір як чинник національної безпеки України. Украӥнознавство. 2005. № 3. С. 182.

${ }_{11}$ Михальченко И. А. Информационные войны на рубеже XXI века. Безопасность информационных технологий. 1998. № 3. С. 14-15.

12 Панарин И. Н. Информационная война и третий Рим. М, 2001. 244 с. 
It is of interest to study the problem of P. Spyga and R. Rudnik ${ }^{13}$, where scientists identify 4 approaches to the definition of this concept:

- the first approach treats them as a set of political-legal, socioeconomic, psychological actions that involve the seizure of information space, the displacement of the enemy from the information sphere, the destruction of his communications, the deprivation of means of communication, and other similar purposes;

- in the second approach, information warfare is the most acute form of confrontation in the information space, where the qualities of interaction such as uncompromising, high intensity of dispute and short duration of intense rivalry are of paramount importance;

- in the third approach, information warfare is interpreted as a form of providing and conducting military forces through modern electronic means (digital transmitters, satellite transmitters and other similar means used for military tasks);

- the fourth approach identifies information wars with cyber wars (confrontation between technical systems).

The ideas of a conflicting approach cannot be overlooked; it allows us to consider the wars analyzed in the context of military and political confrontation.

Accordingly, R. Shafransky interprets the phenomenon under study as armed action against any part of the system of knowledge and beliefs of the enemy, with the purpose of hidden destructive influence on political decisions of the counterparty, which is expressed in violation of coordination and efficiency of this process.

The author emphasizes that the higher the technological capabilities and the more developed the communicative sphere of the state, the more vulnerable it is in the information war $^{14}$.

Through the prism of military-strategic direction, information warfare is viewed by J. Arkill, D. Ronfeldt, and J. Derian. For them, it is a kind of military conflict that acts either as an independent form or as part of an expanded set of hostilities that form a network and cyber war. The possibility of domination in this case is ensured by the

13 Шпига П. С. Основні технології та закономірності інформаційної війни. Проблеми міжнародних відносин. 2014. №8. С. 329.

${ }^{14}$ Szafranski R. Theory of Information Warfare: Preparing For 2020. Official Site of "Airpower Journal". URL: http://www.airpower.au.af.mil/airchronicles/apj/apj95/spr95_ files/szfran.htm 
computerization of military equipment and the formation of a network organization of the armed forces. The use of electronic technologies, automatic devices that replace humans in combat situations is envisaged. In addition, the destruction of the enemy's information systems, which entails the counterparty's inability to receive, process and use the necessary information, is deemed necessary ${ }^{15}$.

As for the second of these directions, in its framework information war is explained as political confrontation.

Thus, in the ideas of A. V. Manojlo, information warfare is a political struggle that is expressed in the form of informationpsychological operations with the use of information weapons and acts as an indispensable attribute of political leadership. The implementation of the war is a heightened influence on the contradictions, objectively laid and take place at different levels of the state social system. As a result, external and internal manifestations of confrontation with a given level of intensity and in a consciously determined direction are expected ${ }^{16}$.

A systematic view of the nature of information wars is also expressed by S. M. Bukharin and V. V. Tsiganov. They reduce information warfare to a dynamic process that occurs in a complex selforganized system with many elements, the relationship between which are not deterministic but probabilistic in nature. Such a war, according to the authors, arises as a result of the advance development of any

component that requires a redistribution of resources in its favor and increased security. This conflicts with other parts of the system and brings it out of equilibrium. The result of the information war is the transformation of the system or its disappearance and the formation of a new organization ${ }^{17}$.

Thus, each of the above approaches gives an opportunity to form an idea of the individual sides of the phenomenon under study. Psychological paradigm allows to study in detail the mechanisms of influence on the intrapersonal processes of individuals, which causes changes in the mental sphere, determines the correction of the logic of worldview and its corresponding political behavior. In the context of the

${ }^{15}$ Der Derian J. Virtuous War / Virtual Theory. International Affairs. 2000. № 4 (76). P. 771-788.

16 Манойло А. В. Государственная информационная политика в особых условиях. М., 2013. С. 245.

${ }^{17}$ Бухарин С. Н. Информационные войны в бизнесе и политике. М, 2007. 336 с. 
social-communicative vision of the problem, it is possible to solve the problem of filling the gaps in knowledge about the nature and methods of interactions that arise between subjects of information confrontation. The geopolitical approach allows us to consider the basic methods of contemporary world politics for achieving political and economic power in peacetime. Conflict direction focuses on an adequate assessment of the strategic importance of information in the attainment of dominant positions as a result of the struggle for power, resources and political status. The systematic approach provides relevant tools for a comprehensive study of the information war. This approach takes into account the close interrelation of its individual elements, their reflection on destabilizing factors and tactics within the framework of offensive strategies.

\section{The main objectives and classification of information warfare}

The information society, by its nature, has caused information wars. Information warfare is a form of information confrontation between different entities (states, non-governmental, economic and other structures), which involves conducting a complex to damage the information sphere of a competing party and protect its own information sphere and has a number of tasks ${ }^{18}$.

The objectives of the information war are:

- creating an atmosphere of breathlessness, negative attitude to culture and historical heritage in the company of a competitor or enemy;

- manipulation of public opinion and political orientation of the population of the state in order to create political tension and a state close to chaos;

- destabilization of political relations between parties, unions and movements with the aim of fomenting conflicts, stimulating mistrust, suspicion, aggravation of hostility, struggle for power;

- provoking social, political, national-ethnic and religious clashes;

- provocation, use of repressive actions by the authorities against the opposition;

- reduction of the level of information support of the authorities and management, inspiration of erroneous administrative decisions;

18 Малик Я. Інформаційна війна і Україна. URL: http://lvivacademy.com/ vidavnitstvo_1/visnyk15/fail/Malyk.pdf 
- misleading the public about the work of state authorities, undermining their authority, discrediting their actions;

- initiating strikes, mass riots, other protests and disobedience;

- undermining the international authority of the state, its cooperation with other states;

- creation or strengthening of opposition groups or movements;

- discrediting the facts of the historical, national identity of the people; changing the value system that determines people's lifestyles and outlook;

- diminishing and offsetting world-recognized achievements in science, technology and other fields, exaggerating the value of mistakes, shortcomings, the consequences of wrongdoing and unqualified government decisions;

- formation of prerequisites for economic, spiritual or military defeat, loss of will to fight and win;

- presenting their lifestyles as behaviors and outlooks of the future that other peoples should follow;

- undermining the morale of the population and, as a consequence, reducing the defense capability and combat potential;

- another destructive ideological influence;

- damage to the security of information and technical infrastructure (hardware, software, tools and mode of protection against unauthorized leakage of information);

- protection against other destructive and informationalpsychological and informational-technical influence ${ }^{19}$.

The main task of the information war between the states is to exert a direct negative destructive influence on the political power of the state by weakening its real and potential capabilities for ensuring its own security, creating difficulties in internal development and conducting active foreign activity, as well as maintaining international relations, causing damage. political image, that is, the weakening of the ruling elite, the socio-political regime established by it, or even the promotion of the latter's removal from power ${ }^{20}$.

19 Петрик В. Сутність інформаційної безпеки держави, суспільства та особи. URL: http:www.justinian.com.ua/article.php.

20 Малик Я. Інформаційна війна і Україна. URL: http://lvivacademy.com/ vidavnitstvo_1/visnyk15/fail/Malyk.pdf 
Of great importance is the definition of the objects of information warfare. In general, an object is something that is directed at an activity, that is, an information warfare entity is trying to influence in order to achieve a positive result for it. Thus, the main focus of direct information destructive influence in the context of information warfare is the public opinion and consciousness of the individual.

The main objects of destructive information influence are:

- resources that reveal the spiritual, cultural, historical, national values, traditions, property of the state, nation in the spheres of society;

- the ideological and psychological environment of society associated with the use of information, information resources and information infrastructure to influence the psyche and behavior of people;

- the information infrastructure, ie absolutely all intermediate points between information and the person;

- the system of formation of public consciousness (outlook, political views, generally accepted rules of behavior, etc.);

- the system of political decision making and decision making;

- the system of forming public opinion;

- human consciousness and behavior ${ }^{21}$.

Purposeful informational influence on the population implies the dominant position of the subject of information war in all spheres of life of another state: economic, political, psychological, religious, scientifictechnical, artistic, as well as inter-national and international relations. The process of increasing the effectiveness of direct undermining measures, including information warfare, is achieved by establishing control over the information space of a foreign country, the accuracy and purposefulness of such actions, taking into account the required volume and level of reliable information that is proven, the degree of differentiation of the population by material and spiritual values. It also manifests itself in the ability to adequately perceive and respond to information, as well as political, economic, ethno-religious and other situations in the country and in the region.

Today, there are many different technologies of negative impact on the spiritual and ideological sphere of life of society, which can be used by special services of foreign states, terrorist organizations, politicized

${ }^{21}$ Петрик В. Сутність інформаційної безпеки держави, суспільства та особи. URL: http:// www.justinian.com.ua/article.php. 
radical organizations, criminal structures, transnational corporations and other formal and informal participants in modern international legal relations.

Therefore, in the conditions of transformation of information war its forms will also change. Yes, the first generation information fight is:

- fire suppression (in wartime) of elements of infrastructure of state and military management;

- conducting electronic warfare;

- obtaining intelligence by intercepting and decrypting information flows;

- unauthorized access to information resources with their subsequent falsification or abduction;

- mass submission in the enemy information channels or global misinformation networks to influence decision-makers;

- obtaining information from the interception of open sources of information $^{22}$.

The information generation of the second generation involves:

- creation of a system of spirituality and immorality, negative attitude to the enemy's cultural heritage;

- manipulation of the social consciousness of social groups of the population in order to create political tension and chaos;

- destabilizing political relations between parties, unions and movements in order to provoke conflicts, foment distrust, suspicion, intensify political strife, provoke repression against the opposition and even civil war;

- reduction of the level of information support of the authorities and management, inspiration of erroneous administrative decisions;

- misinformation of the population about the work of state bodies, undermining their authority, discrediting government bodies;

- undermining the international authority of the state, its cooperation with other countries;

- damage to the vital interests of states in political, economic, defense and other spheres ${ }^{23}$.

It is a well-known fact that information warfare is inherent in information weapons - it is a type of weapon, the main elements of which

22 Iнформаційна війна. URL:uk.wikipedia.org/wiki/
${ }^{23}$ The same resourse. 
are information, information technologies (including technologies of information influence), information processes and technical means used in information warfare ${ }^{24}$.

At the same time, the purpose of an information war is to weaken the moral and material forces of the opponent or competitor and to strengthen their own. It envisages measures of propaganda influence on human consciousness in ideological and emotional fields. After all, information warfare is an integral part of the ideological struggle. It does not lead directly to bloodshed, destruction, no casualties during its conduct, no one is deprived of food, a roof over his head. And that creates dangerous security for her. At the same time, the destruction caused by the information wars in social psychology, personality psychology, in scale and importance is quite commensurate, and sometimes exceeds the consequences of the armed wars.

It should be noted that the main task of information wars is to manipulate the masses. The purpose of such manipulation is often to:

- introducing into the public and individual consciousness hostile, harmful ideas and views;

- disorientation and misinformation of the masses;

- weakening of certain beliefs, devices;

- intimidation of his people as an enemy;

- intimidating the enemy with his power.

Finally, the last but not least task is to provide a market for its economy. In this case, information warfare is an integral part of competition. The purpose of the information war is to disrupt the exchange of information in a competitor's camp. It is easy to understand that this type of weapon is generally not aimed at the task of losing manpower. In this sense, the technology curve finally led to a bloodless and at the same time extremely effective weapon. It does not destroy the population but the state mechanism ${ }^{25}$.

A completely different problem with the use of the term "information war" is the constant variation or interchangeability of the first word: often in the sense of "information" refers to the war "psychological", "communication", "information technology",

${ }^{24}$ Петрик В. Сутність інформаційної безпеки держави, суспільства та особи. URL: http:// www.justinian.com.ua/article.php.

${ }^{25}$ Маруненко О. Зовнішні і внутрішні інформаційні війни у медійному просторі України. Освіта регіону. Політологія, психологія, комунікащіï. 2011. № 4. С. 92. 
"unconventional" (unrelated to the use of traditional weapons), "irregular", "virtual", etc. In most cases, such nominations only outline the main types and subspecies of the information war.

The typological ranks of information wars that M. Libiki started talking about are expanding every year. The division into species is carried out mainly by a number

of criteria: it is usually taken into account what the impact is directed to, for what purpose, through which tools. In general, the following types of information wars are distinguished:

1) command and control (confrontation for capture or disturbance of command and control mechanisms in the armed forces of the state);

2) intelligence (confrontation with the help of intelligence and counterintelligence information);

3) financial and economic (information and economic wars for control of trade, mastering of information necessary for superiority over competitors);

4) electronic, hacker, cyber-war (impact on electronic communications - radio, television and computer networks)

5) psychological (carried out through propaganda and manipulation with the purpose of undermining the public spirit, demoralizing the armed forces, discrediting the culture, disorienting the command of military forces or heads of the legislative and executive power); psychological wars have their subspecies by the nature of the influences used ${ }^{26}$.

a) information-psychological (propagate certain ideas, views, ideas, beliefs, create the basis for positive or negative mass psychic reactions);

b) psychogenic (accompanied by the effects of physical factors sound, lighting, temperature, as well as the generation of a state of shock from certain tragic events - deaths, destruction, etc.; consequences irrational behavior, emotional affect, depression, panic);

c) psychotropic (influence - lateral programming - is carried out by the transmission of information through unconscious perception; in the case of neurolinguistic programming - by means of special linguistic programs for changing the motivation of people and their behavioral reactions);

${ }^{26}$ Чистоклетов Л. Г. Інформаційно-психологічні впливи як невід'ємна складова парадигми інформаційної. Науковий вісник Львівського державного університету внутрішніх справ. 2012. №2(1). С. 186-187. 
6) networking (a set of information influences between social groups in social and professional networks to gain certain advantages in economic, military, political, cultural and public confrontations):

a) high-tech networking (modern, high-tech digital communications based on television, radio, Internet, messenger, cellular, satellite and other modern communications and based on gadgets such as fixed computer devices, tablets, smartphones, personal and group devices);

b) high-tech networking (modern, high-tech humanitarian technologies for creating, storing, disseminating and retrieving information; these include SMM, SEO, targeting, contextual advertising, media viruses);

c) High-Sensor Networking (modern high-tech psychology that allows to regulate and manage social communication processes at the level of social groups and individuals; typical in this aspect are social psychology, applied psychoanalysis and NLP) ${ }^{27}$

G. Pocheptsov, citing U. Schwartau's research, in his book "Information Policy", cites another classification of information wars, built "on the level of objects: from one person to the whole state". According to this criterion distinguish:

1) personal information war, where different types of manipulations with personal electronic information belong;

2) corporate information warfare, where information systems attack situations are classified;

3) a global information war, where information is regarded as a national asset that can be hunted by other countries ${ }^{28}$.

The IT revolution has opened up vast opportunities for influencing peoples and power, manipulating people's consciousness and behavior, even in remote spaces. Given the globalization of communication networks in the world, it can be assumed that it is the information types of aggression that will be given priority in the future.

Information wars are taking place in modern Ukraine. In particular, the well-known Russian politician B. Nemtsov described the information war, which is the information support for the aggression of the Russian

${ }^{27}$ Курбан О. В. Сучасні інформаційні війни в мережевому он-лайн просторі : навчальний посібник. Київ, 2016. С. 46-50.

${ }^{28}$ Почепцов Г. Г. Інформаційна політика : навчальний посібник. Київ : Знання, 2008. C. 564. 
Federation against Ukraine, as a war of the Nazi regime against a democratic state.

Information war as an aggressive interaction of the opposing parties in the information sphere has a negative impact on the state of political communications of the society as a whole. The use of such campaigns by political actors is associated with increased risks, resulting in a rapid change in statuses and positions in power relations. Due to the high intensity of disputes, information wars are poorly managed and deliberately regulated and therefore act as a two-pronged weapon for the opposing parties. Achieving goals in such ways enhances political confrontation, reduces the possibility of spreading a consensus culture, undermines stability in society.

\section{CONCLUSIONS}

The concept of "information war" is not an allegorical image, it reflects a kind of war, a form of warfare which is an information struggle. Its high efficiency was confirmed by the scale and results of the Cold War, which was the most striking in comparison with the previous world wars, although it was carried out without the resolution of the armed struggle, as well as the experience of local wars and armed conflicts of our time. The essence and role of information warfare is devoted to a large number of publications in which it is viewed differently. The definition of information warfare can be grouped as follows: the definition of information warfare in a narrow sense - reflects a purely military orientation, and the definition in the broad sense - the focus on ensuring national interests in any vital sphere of state and public activity.

Factors of origin and vitality of ideas of information war, according to various estimates are as follows:

- the world economy dictates and its world laws are increasingly humane. The main one is simple: war (in the traditional sense) is not economically viable. This is one of the systemic factors contributing to the spread and development of humanistic tendencies;

- the cost-effectiveness of information weapons, which will, on the one hand, reduce to some extent the military budget and, on the other, create highly effective weapons of the 21 st century, the use of which will have promising results; 
- the mass use of information weapons, according to Western experts, will allow relatively quickly to suppress the enemy, paralyze him, to force surrender without the involvement of the armed forces, without the usual battles typical of classic wars, without the death of people and the destruction of civilian infrastructure, and finally without loss of personnel.

Due to the fact that information warfare is a multifaceted and complex phenomenon, it is conducted in various dimensions, involves the use of a conglomerate of techniques, raises the question of overcoming the framework's limited individual theoretical constructs. On this basis, the author concludes that it is necessary to apply a polyparadigmatic approach to the study of information war as one of the aspects of contemporary socio-political reality.

\section{SUMMARY}

The article defines the essence of the concept of "information warfare" and reveals the reasoned concepts of information wars. The main attention in the work focuses on the theoretical and methodological positions of scientists belonging to various scientific schools and defining information warfare through specific aspects of the problem.

The concept of information war, forms and types of information wars, their action against society are revealed.

It has been proven that information weapons are emerging as the main the information warfare tool cannot be used on its own; there are necessarily entities seeking to exploit, for useful and criminal purposes, the positive properties of information and information technology that have been created for the benefit of man, society and the state.

\section{REFERENCES}

1. Бухарин С. Н. Информационные войны в бизнесе и политике. М, 2007. 336 с.

2. Гриняев С. Концепция ведения информационной войны в некоторых странах мира. URL: http://www.soldiering.ru/psychology/ conception_psywar.php

3. Гуз А. М. Історія захисту інформації в Україні та провідних країнах світу : навчальний посібник . К.: КНТ, 2007. 260 с.

4. Інформаційна війна. URL: uk.wikipedia.org/wiki/ 
5. Карпенко В. Інформаційний простір як чинник національної безпеки України. Українознавство. 2005. № 3. С. 182-192.

6. Курбан О. В. Сучасні інформаційні війни в мережевому онлайн просторі : навчальний посібник. К, 2016. 286 с.

7. Лисичкин В. А. Третья мировая (информационно-психологическая) война. URL: http://malchish.org/lib/politics/infwar.htm

8. Малик Я. Інформаційна війна i Україна. URL: http://lvivacademy.com/vidavnitstvo_1/visnyk15/fail/Malyk.pdf

9. Манойло А. В. Государственная информационная политика в особых условиях. М, 2013. 320 с.

10. Маруненко О. Зовнішні і внутрішні інформаційні війни у медійному просторі України. Освіта регіону. Політологія, психологія, комунікації. 2011. № 4. С. 92-96.

11. Михальченко И. А. Информационные войны на рубеже XXI века. Безопасность информационных технологий. 1998. № 3. C. $14-15$.

12. Панарин И. Н. Информационная война и третий Рим. М., 2001. 244 c.

13. Петрик В. Сутність інформаційної безпеки держави, суспільства та особи. URL: http://www.justinian.com.ua/article.php.

14. Почепцов Г. Г. Інформаційна політика : навчальний посібник. 2008. 66 с.

15. Проноза I. I. Інформаційна безпека держави: сутність та основні визначення. Гілея : науковий вісник. Збірник наукових праць. 2017. № 127(12). C. 345-349.

16. Проноза I. I. Інформаційна війна: сутність та особливості прояву. Актуальні проблеми політики. Збірник наукових праџь. 2018. № 81. C. 79-84.

17. Расторгуев С. П. Философия информационной войны. М, 2003. $496 \mathrm{c}$.

18. Чистоклетов Л. Г. Інформаційно-психологічні впливи як невід'ємна складова парадигми інформаційної. Науковий вісник Львівського державного університету внутрішніх справ. 2012. №2(1). C. 183-193.

19. Шпига П. С. Основні технології та закономірності інформаційної війни. Проблеми міжнародних відносин. 2014. № 8. C. 326-339. 
20. Der Derian J. Virtuous War / Virtual Theory. International Affairs. 2000. № 4 (76). P. 771-788.

21. Szafranski R. Theory of Information Warfare: Preparing For 2020. Official Site of "Airpower Journal". URL: http:// www.airpower.au.af.mil/airchronicles/apj/apj95/spr95_files/szfran.htm

Information about the author: Pronoza I. I.

Candidate of Political Sciences, Senior Lecturer at the Department of Political Sciences and Law, South Ukrainian National Pedagogical University named after K. D. Ushynsky 26, Starofrankivska str., Odessa, 65000, Ukraine 


\section{FEATURES OF REGIONAL IDENTITY FORMATION IN THE UK AND ITALY: COMPARATIVE ANALYSIS}

\section{Rostetska S. I.}

\section{INTRODUCTION}

The current political processes in the countries of Europe as well as all over the world are characterized by increasing importance of the regional factor. At the same time, the concept of the region is complicated and not limited to geographical, ethnic and confessional borders. Regions are involved in international economic cooperation, unite in interregional associations, based on the principle of subsidiarity, support a diversity of self-interest, including not only economic, but often ethno-cultural, which go beyond one state. The formation and promotion of regional identity have become an integral part of the complex of international and foreign economic regional ties.

Each country is characterized by its own peculiarities of national identity formation policy based on regional identities. It is the interaction of regional identities within a single political space that may occur in different ways: the processes of ethno-linguistic and cultural synthesis are initially completely different regional identities; building a multicultural space around the core, central in the cultural and ethnic sense of the nucleus; finding a compromise between different ethnic and linguistic groups; the exclusion from the political order of the need to integrate regional identities into national unity while preserving their cultural and other identity, etc.

Active search for the foundations of identity, keen interest in the past country, attempts to define the content of such concepts as a citizen, nation - all these issues are actualized in modern society. Therefore, the purpose of this section is to provide a comparative analysis of the specifics of the process of regional identity formation in the Greater Yurian and Italian territories, countries with examples of devolution in the Center-Regions system, the existence of separatist tendencies and conflicts. 


\section{Features of regional identity in the UK}

With the increasing popularity of the ideas of globalism, the modern nation-state is experiencing a crisis of socio-political order. In recent decades, processes of political disintegration have emerged in many federal and unitary states of Western Europe. This process is particularly striking at present in the United Kingdom. Today, the UK is the only country in the world that fully adheres to its traditions, including in the political and political sphere, which is largely governed by customs. It is tradition that allows the English royal dynasty to still have strong power.

It has happened historically that the United Kingdom has been developing and becoming a centralized state. This development implied that the formation, first and foremost, of national identity ("Britishness") and the maximum weakening of Celtic regional (ethno-national) identities in the country.

However, it should be noted that this only weakened, but in no way destroyed, the regional identity of the Celtic periphery population. To date, "Scottish", "Welsh", "Irish" exist and develop as fully conscious identities, and which are supported by part of the population of the Celtic regions. An important feature of these regions and the communities that live there is that they identify not only as Scots, Welsh, Irish, but also emphasize their "Europeanness" as opposed to "British" affiliation.

For example, it is indicative that respondents across the United Kingdom identify themselves with their country of residence (region), that is, their priority is regional identity, not Britain as a whole. In figures, this is follows as: (60\% vs. 25). Yes, Scotland, according to 2014 , only $8 \%$ of respondents stated their British identity (in Wales, for example, $17 \%$ and in Northern Ireland $40 \%$ ). In terms of double selfidentification, $18 \%$ of Scots position themselves as such (for comparison, 7\% said in Wales, 9\% in England and 8\% in Northern Ireland $)^{1}$. And important for further research is that for years these figures have not actually changed.

Speaking separately from the Celtic regions, most of Scotland's people feel, above all, Scots. At the same time, 94\% of those born in Scotland choose Scottish identity as the only or most important identity

\footnotetext{
${ }^{1}$ National identity and ethnicity in Scotland. ESRC Centre on dynamics of ethnicity. URL: http://www.ethnicity.ac.uk/medialibrary/briefings/dynamicsofdiversity/code-censusbriefing-national-identity-scotland.pdf (Accessed 23.05.2019).
} 
among other identities. The respondents describe "Scottishness" in very positive terms, pointing to the openness and loyalty of the society. In making a comparative analysis of Scottish and English identically, it is worth noting the traditional strength of Scottish and some weakness of English. In addition, Scots associate themselves with Europe (this can be explained by the absence of controversial factors), unlike in Britain, where the very notion of "Scots" - "British" causes controversy.

In Northern Ireland, the ideas of "Britishness" are extremely important to the Protestant part of the population, and Northern Irish Protestants can be called greater British patriots than Englishmen. But at the same time, most residents of Northern Ireland also call themselves Europeans. And in this sense Protestants and Catholics have a common position. paradoxically, it turns out that the "Britishness" of the Northern Irishman differs from the "Britishness" of the Englishman. In 2011, a fifth of the region's population identified itself as Northern Irish. In this respect, the situation has also improved in terms of relations between Protestants and Catholics, since in 1998 only up to $10 \%$ of Catholics declared their "Britishness". In 2014-2015, 29\% of the population identified themselves as Northern Irish, a quarter as Irish (25\%), 2/5 as British $(40 \%)^{2}$.

Speaking of Wales, 58\% of the population identify themselves exclusively as Welsh and only 7\% call themselves both Welsh and British at the same time. The definition of "Welsh" is linked and based on knowledge of Welsh culture and Gaelic. Therefore, those who know and share Welsh culture and language are more likely to choose Welsh identity only and do not call themselves British. The Welsh also believe that they are, above all, Europeans, and later British ${ }^{3}$.

It is important that even the British themselves do not share the "Britishness". Of those, 3/5 say they are British, not British. Less than a tenth of England's population opt for a dual identity. $72 \%$ call themselves exclusively British, and $58 \%$ call themselves British rather than British ${ }^{4}$.

\footnotetext{
${ }^{2}$ Northern Ireland identity. URL: http://www.niassembly.gov.uk/globalassets/ documents/raise/knowledge_exchange/briefing_papers/series4/northern_ireland_identity_ga rry_mcnicholl_policy_document.pdf (accessed 16.05.2019).

${ }^{3}$ Welsh identity. URL: http://www.ethnicity.ac.uk/medialibrary/briefings/ dynamicsofdiversity/code-census-briefing-national-identity-wales.pdf (Accessed 10.05.2019).

4 English national identity. URL: http://www.walesonline.co.uk/news/walesnews/rise-english-national-identity-threatening-4880115 (Accessed 03.04.2019).
} 
It should be noted that "Englishness", unlike "Scottishness", "Welshness" and "Irishness", is already linked to Euroscepticism.

It is quite obvious that "Britishness" is undergoing a transformation, as both European and regional (including ethno-national) identities are influenced by it. Britain itself is undoubtedly linked to the country's history, expansion and world leadership. It is based on the unique geographical location of Britain, the constitution (in the form of collections of legislation), a rich history with the status of a maritime superpower. Thus, these factors construct British identity, and in times of crisis they always manifest themselves most strongly. The British themselves, decomposing "Britishness" into elements, indicate that its supports are Protestantism, empire, heavy industry (which in the past), but no new unifying elements are traced ${ }^{5}$. It was in the quest to preserve "Britishness" based on the democratic values and unity of the four nations (English, Scots, Welsh and Irish) that devotional models were developed. They were, in practice, supposed to confirm the existence of the fortress of the British Union and the readiness of the political system for democratic change.

There are three types of devolution in the theoretical dimension:

1) administrative - for example, setting up Government Offices in the regions, or, as it was before 1999, the practice of delegating powers from central government departments to the territorial ones of the same state;

2) executive - the exclusive rights of the United Kingdom Parliament are vested in the Ministries of Devolution Governments by statute;

3) Legislative - The United Kingdom Parliament delegates some of its powers to a subordinate legislature. Thus, the content of the legislative devolution lies in the creation of regional representative bodies (local parliaments, assemblies) that elect the population, and in granting them the right to "define policies and legislate" within the designated territories. That is, they are the supreme legislative authority with the power to resolve regional problems at the legislative level ${ }^{6}$.

${ }^{5}$ Hunt T. Labour must embrace Englishness // The Guardian. 5 February 2016. URL: https://www.theguardian.com/commentisfree/2016/feb/05/labour-embrace-englishnessproud-patriotism (Accessed 13.05.2019).

${ }^{6}$ Gerven W. Federalism in the US and Europe. ICL journal. 2007. Vol. 1. URL: http://www.internationalconstitutionallaw.net/journal. 
Devolutionary regulation in the United Kingdom is often characterized as asymmetric - there are significant differences between the arrangements in each country.

Note that with the introduction of the Declaration, the UK central government sought to block separatist tendencies in the regions (primarily in Scotland and Northern Ireland), to reduce political tensions between the center and the provinces by redistributing powers to the regions. This is what political leaders of regional movements sought to achieve. Thus, it is obvious that the British government's devolution was a kind of precautionary measure, a forced political step, a response to growing regional demands.

The essence of these devolution models is as follows. Following the referendums held in Scotland and Wales in September 1997, most voters supported the creation of a Scottish Parliament with the power to levy income tax and the National Assembly of Wales. In Northern Ireland, devolution was a central element of the Belfast Agreement, supported by referendums held in both Northern Ireland and the Republic of Ireland in May 1998. Following the referendums, Parliament adopted three legislation on devolution establishing the authorities with limited autonomy and defining the relevant powers - the Scotland Act (1998), the Northern Ireland Act (1998) and the Wales Government Act (1998). These legislative acts were subsequently amended, in particular, the Scotland Act (2012) extended the powers of the Parliament of Scotland, and the Government of Wales Act (2006) is now the central legislative body on which the Wales system is based. Elections to all legislatures with limited autonomy include an element of proportional representation, unlike the Westminster Parliament, whose members are elected by majority system.

The transfer and separation of powers differ in the three systems of limited autonomy. Foreign and defense issues remain at UK level, but instead there are a number of powers delegated to Scotland, Wales and Northern Ireland, in particular in the areas of agriculture, health and housing. At the same time, other powers, such as law enforcement and criminal justice, were transferred to Scotland and Northern Ireland but not to Wales. Local government issues are also the responsibility of the authorities of Scotland, Wales and Northern Ireland ${ }^{7}$. Thus, the principle

${ }^{7}$ The Implications of Devolution for England. URL: http://www.gov.uk/government/ publications (Acessed 17.05.2019). 
of dispersion in the UK is based on the principle of dispersion, in a sense of variational variance of management functions, depending on the specificity of the region. The model envisages the transfer of part of the power to the territorial level of the respective regions and the creation of an asymmetric model of governance, in which the regions are given specific functions and certain powers to regulate processes, especially in the sphere of economy and social relations, with the principle of clear limitation of the spheres of influence of the region power.

It should be noted that the peculiarities of devolution in the UK are due to the influence of internal and external factors, in the ratio of which the determining role belonged to internal factors.

Endogenous factors are related to the persistence of internal problems of the regions, uneven socio-economic development and the growing influence of the ethno-regional elite, which offers its own interpretation of the state of affairs and prospects for the development of the region.

External, exogenous factors are associated with processes such as globalization and European integration on the one hand, and differentiation and regionalization on the other.

In the context of globalization, the influence of the exogenous component is also increasing in the UK. The regions are beginning to act as agents of European politics and defenders of cultural heritage. On the one hand, the trend towards regionalization is increasing at the expense of the EU. For example, the Maastricht Treaty provided for the formation of a Committee of the Regions. Interregional cooperation financed by the Structural Funds has expanded. The new European Regional Strategy provided for funding and investment at the level of regions, but not states. On the other hand, the regions themselves show a desire to participate effectively in the implementation of their plans, not only at the regional but also at the European level, through the expansion of regional powers. Thus, the factors of globalization, Europeanization of socio-economic development, both state and ethnic regions in its composition, have a stimulating influence on regional and its kind of ethnic identity ${ }^{8}$. For the United Kingdom, European

8 Ерёмина Н.В. Факторы роста европейского этнорадикализма на примере Шотландской национальной партии и Североирландской партии «Шинн Фейн». Политическая экспертиза: ПОЛИТЭКС. 2010. Т. 6. № 1. С. 179-189. 
integration has become one of the problems of increasing national movements, and as a result of strengthening regional and ethnic identity. European integration has become a mainstay for ethnoregional communities since the mid-1970s, when they realized for themselves the financial and political appeal of the integration project. Communitarian policy, on the one hand, promotes the growth of ethnic nationalism and regionalism, but on the other hand, it promotes this movement into a more acceptable political and legal form and allows the concept of a "Europe of the Regions" to be attached to the construction of regional collective identity. It clearly demonstrated itself in the late 1990s. and at the beginning of the XXI century. The Charter of Regionalism, adopted by the European Parliament in 1988, as well as the Council of Communities and Regions of Europe and the Assembly of Regions of Europe, aiming at strengthening the political representation of regions at all levels, are aimed at acquiring ethnic regional minorities with the political protection of their identities.

Supporting European identity is represented not so much by the state as by the large groups of regions of these states, because they are interested in solving existing socio-economic problems at the expense of EU financial resources, as well as raising their status within the common European space. Therefore, in spite of the cultural peculiarities of the ethno-regional communities, they are, in the first place, ready to support European initiatives and call themselves Europeans.

It should be noted that it is important that the level of "Europeanness" is always higher where there is a sufficiently high level of awareness among the population of regional ethnic identity. For example, in the UK as a whole (especially in England) the notion of 'Europeanness' is often taken with caution, while in national regions, European integration is invariably endorsed. Scotland, Wales and Northern Ireland have opened their own offices in Brussels and are actively involved in the work of the Committee of the Regions and in the European Parliament. EU financial assistance to ethno-national regions of the United Kingdom is essential for their development. Especially great support is given to those regions that face a number of structural problems. For example, Wales received $€ 2.7$ billion in EU 
subsidies from 2014 to $2020^{9}$. 40. EUR 5 billion allocated to Scotland for the same period ${ }^{10}$. And about $€ 3.5$ billion has been earmarked for Northern Ireland ${ }^{11}$. The United Kingdom Government guarantees that all these payments will be maintained in the regions, even after the brutal Brexit to which the UK is preparing. However, the results of the Brexit referendum were not welcomed by the regions. And here not only the economic component. The referendum results have two dimensions: internal and external. Speaking of the internal dimension, firstly, Euroscepticism was and still is the prevailing idea over Eurooptimism in the political consciousness of the British. Secondly, it is the small parties that have formulated their position vis-à-vis the EU, avoiding a split. For example, the Scottish National Party has generally advocated maintaining EU membership. Thirdly, with the withdrawal of Britain from the EU, the norms of communication cease to exist. It also calls into question a number of constitutional acts, such as in the case of Northern Ireland, where the Republic of Ireland is a party. Fourthly, the exacerbation of London's relations with the Celtic regions, notably with Scotland, whose first minister, N. Sturgeon, held a decision in the Scottish Parliament on the second referendum on the region's independence in 2019, provided that Scotland will not be offered the compromise option of maintaining its links with the single European market. However, the Danish sample cannot be applied to Scotland, since in the case of Denmark, part of it (Greenland) is not part of the EU, while the situation in the United Kingdom is diametrically opposite. It is important that Northern Ireland will also need a similar reorganization and reformatting of interaction with the center.

Therefore, the United Kingdom with its four key regions is of particular interest in the context of the study of complex faults that are not limited by the line of separation between civic (British) and ethnic identity.

${ }^{9}$ EU funding in Wales. URL: http://gov.wales/funding/eu-funds/2014-2020/?lang=en (Accessed 23.05.2019).

10 EU funding in Scotland. URL: http://www.parliament.scot/ResearchBriefings AndFactsheets/S5/SB_16-89European_Union_Funding_in_Scotland_2014-2020.pdf (Accessed 25.05.2019).

${ }^{11}$ EU grants to Northern Ireland. URL: http://www.newsletter.co.uk/news/business/ where-do-eu-grants-to-northern-irelandgo-1-7233873 (Accessed 21.05.2019). 


\section{Specificity of formation of regional identity in Italy}

Under the Constitution, Italy is a unitary state, but in reality Italian unity is a rather shaky concept. The unification of the country under the auspices of the Piedmont monarchy happened a century and a half ago, but regional differences are still being traced.

First of all it is necessary to remember the historical past of the country. The late unification of Italy (on a scale of European history that took place just 150 years ago) played a direct role in what the current level of national and regional identities of the Italians is. The term "Risorgimento" is used to refer to the beginning of the formation and development of national consciousness. In today's Italian reality, there is still no consensus on the periodicisation of the process of the Risorgimento-National Liberation Revolution, which spanned much of the nineteenth century. Traditionally, the year of unification of Italy is considered 1861, but with many reservations. There is still debate over when exactly this process began, since even after the Congress of Vienna in 1815 the chances of unification were very slim: the very idea of the Italian nation seemed distant and not even particularly desirable to most Italians. Italy existed only as a geographical concept, and nothing more. And as Valerio Lintner rightly points out in his work Italy. The history of the country "in the process of Risorgimento and the unification of Italy can not see the historical inevitability caused by insurmountable forces. Rather, it was a series of unrelated and even accidental events that culminated in the creation of the historical and largely culturally logical and coherent unity we are now seeing ${ }^{12}$.

For many generations of Italian researchers, the key phrase was attributed to one of the creators of Risorgimento, an active participant in the process of political unification of the state of Massimo d'Adzello: "We created Italy, now we will create an Italian." This statement largely explains the relevance and importance of the problem of selfidentification at the time of territorial unification of the country.

Modern famous Italian specialist IB Levin on the subject writes the following: "Focusing on the absence of the Italian" in "already made" the only national-state space of the Italian Kingdom, Massimo d'Adzellio sent to the heritage of centuries-old fragmentation of the country, ... The call to "make Italian" was sometimes read as the need to end the

\footnotetext{
12 Линтнер В.Италия. История страны. М., 2008. С. 194.
} 
fragmentation of the territorial-administrative classification of the inhabitants of the peninsula. In addition, the country was divided into many provinces and municipalities: by the time of unification, it had 7721 cities (in neighboring France twice as many as 1,307), with which 713 date back to the evenings of 1971 and to the Roman era (not coincidentally the medieval metaphor of Italy was the "country of cities"). Not every of these settlements was the center, capital, citadel of something - duchy, county, abbey, etc. -and jealously oversaw his own orders, traditions, customs ${ }^{13}$.

For example, in language. In the years of Risorgimento, only one resident of forty could speak the so-called standard Italian - the other thirty-nine spoke local dialects. Common to all languages, created on the basis of the Florentine dialect of Dante and Boccaccio, was able to suppress (but not supplant) only the spread of radio and television, but linguistic unity has not yet been achieved. Any resident of the country is able to determine one or two phrases without fail, from which area and even from which city his interlocutor comes. It is often the case that as soon as one Italian switches from the standard language to his dialect, the interlocutor ceases to understand it.

The language differences are not limited. Many residents of Italy perceive themselves primarily as Venetians or Neapolitans, and only in the second - as Italians. Administratively, the country is divided into twenty regions, but there is another, informal division into the North and South. The North is rich so much that living standards are virtually inferior to Northern Europe. Against this background, the South looks to be another country: income levels in Calabria, Campania, Apulia and Sicily are twice lower than in Lombardy, Veneto and Emilia Romagna.

In a very simplified form, the existing economic division of Italy can be drawn to the following picture: there is a dynamic industrial and financial center in the North and a semi-agrarian inert periphery in the South.

The claims that Southerners and Northerners make to each other is a long story. The process, which in the North was regarded as the

13 Левин И.Б. Национальная идентичность в условиях глобализации (на материале Италии) // Новые тенденции во внутренней политике развитых стран. М., 2005. C. 89. 
unification of Italy, was perceived by many in the South as the illegal conquest of the Kingdom of both Sicily Piedmont (a brilliant account of this point of view was given by Tommaso di Lampedusa in Leopard). Mussolini's attempt to forge a single nation from the inhabitants of the Apennine Peninsula, the heir to the Roman Empire, was unsuccessful and left a bad memory.

In Italy, as in the world as a whole, the region is becoming an important level of political and economic dialogue, where national, supranational and global forces meet local requirements.

One of the acute problems that is closely linked to regional identity is the problem of separatism in Italy.

According to the Italian Constitution, five regions have specific forms and conditions of autonomy: Friuli-Venezia Giulia, Sardinia, Sicily, Trentino-Alto Adige and Valle d'Aosta. These regions have the highest political and economic importance among all the administrativeterritorial units of the Italian state. They have the most pronounced and separatist sentiment. This is primarily due to historical reasons. For example, much of the province of Friuli-Venezia Giulia adjacent to Trieste was transferred to Yugoslavia after World War II. Ethnic and linguistic Slovenian minorities are distinguished from a number of linguistic minorities. In the Trentino-Alto Adige region, which includes the autonomous provinces of Trento and Bolzano, about $70 \%$ of the inhabitants are ethnic Germans, because previously these territories were part of the Austro-Hungarian Empire. After the First World War, under the Treaty of Saint-Germain, Trentino and the Southern Triol moved to the Italian Kingdom.

In Sicily, the Party for the Autonomy Movement operates, headed by the governor of the region R. Lombardo. The party is represented, albeit poorly, in both houses of the Italian Parliament. Its center-right program does not go beyond broad economic and political autonomy. There is also a more radical party in Sicily, the Movimento per l'Indipendenza della Sicilia (MIS), which originated from the Sicilian independence movement of 1943-1947. decolonization, self-determination, independence and the struggle against Italian politics in Sicily. The 
impact of these organizations is currently small ${ }^{14}$. In Valle d'Aosta since 1948, Franco-Italian bilingualism has been officially recognized, with French fulfilling its statutory and representative function. Meanwhile, sociological research conducted in 2011 found a significant advantage in favor of the Italian language. According to the results of the polls, $71.58 \%$ of respondents called it their native language, $12.16 \%$ of the respondents speak different dialects / dialects, 3.21\% speak French, $0.99 \%$ speak French. The same identifier for the region is the FrancoProvencal speeches. The very notion of "speech" (Fr. Patois) in Valle d'Aosta lost its negative connotation; on the contrary, speech is called "the language of the heart," which implies a particular attachment of the Waldostants to their native speech ${ }^{15}$.

In Sardinia, for many years there has been a movement for independence from Italy and any other state (Indipendentismu SARDU). Its development is due to the fact that, as his ideologues insist, Sardinian culture is significantly different from Italian, and also with the threat of the gradual disappearance of the Sardinian language. In addition, a group called "CantonMaritimo" ("Maritime Canton") was created on the social network Facebook, which aims to annex Sardinia to Switzerland. It expresses the position of the Sardinian Party of Action. A. Caruso, one of the founders of the movement, proposes to transfer the island of Switzerland as compensation for public debt, as the officially recognized unemployment rate on the island is $18.1 \%$. Back in 2012, a poll showed that $40 \%$ of Sardinians would vote for separation from Italy. ${ }^{16}$

The main qualitative indicator that distinguishes separatist movements in Italy, and moreover, is how influential and active are the associations and their ideas. At present, separatist movements have a strong influence on areas in the northern part of the country. This is primarily due to economic factors: for example, the unemployment rate in

14 Баранов А.В. Сепаратизм в современной Италии: факторы развития, институционализация, политические стратегии. Человек. Сообщество. Управление. 2015. T. 16. № 12. С. 85.

${ }_{15}$ Моисеева Д.П. Валле-д’Аоста на перекрестке языков и идентичностей. Россия u Запад: диалог культур. 2015. № 8. URL: http://www.regionalstudies.ru/ journal/homejornal/rubric/2012-11-02-22-11-32/366-q-q.html (Дата обращения: 23.05.2019).

16 Баранов А.В. Сепаратизм в современной Италии: факторы развития, институционализация, политические стратегии. Человек. Сообщество. Управление. 2015. T. 16. № 12. C. 87. 
Italy in March 2016 was $11.4 \%$, and in the south, for example, in Sicily, the unemployment rate is twice as high as the national average. That is why the inhabitants of the north consider themselves as "producers" and the southern regions as "consumers", and consider it more profitable to create a state without the southern regions.

The growing discontent of the North towards the South led to the creation of the Northern League for the Independence of Padania (Lega Nord per l'Indipendenza della Padania). The League of the North was created in 1989. It advocates the creation of an independent state falling with the capital in Milan by giving the northern provinces independence from the agrarian South. There are two trends in the programming documents of the League of the North: on the one hand, it emphasizes the belonging of the northern regions (Padania) to European identity and their active participation in the global economy; from the outside. One of the basic principles proposed by the League of the North is the point about the creation of tax federalism. In general, the ideology and political actions of the League of the North did not lead to a serious threat to the national unity and territorial integrity of Italy. At the same time, they have made a significant contribution to the process of a certain transformation of the country's political system in the EU, namely the process of "devolution", ie the transfer of broader administrative and financial powers from the central government to the regions ${ }^{17}$. The results of the 2018 parliamentary elections in Italy have shown that Eurosceptics have widespread support in society. And it was the League of the North, which changed its political power to the League, received a large percentage of the vote. The parliamentary elections stipulated that the electors voted simultaneously for both the lower house and the senators. According to the results of the Senate elections, the rightmost populists from the "League of the North" are Matteo Salvini, Forza Italy ("Forward, Italy") Silvio Berlusconi and the National Conservative Party "Brothers of Italy". Second place - using the left slogans of the Five Star protest movement with Luigi di Mayo (over 32 percent). The Social Democrats came in third with almost 23 percent of the vote. In the

${ }^{17}$ Giorgia Bull and Filippo Tronconi. The elusive nature of the Lega Nord // Mapping the Extreme Right in Contemporary Europe: From Local to Transnational / Andrea Mammone, Emmanuel Godin, Brian Jenkins. Routledge, 2012. P. 123. 
lower house of the parliament, center-right leaders lead by 37 percent of the vote, 32.7 percent in the Five Star Movement, and the Social Democrats gain about 23 percent (with the ruling Democratic Party at the same time, about 19 percent) ${ }^{18}$.

Moreover, a new government was formed in Italy - three months after the election, which led to a strange alliance of the Left 5 Star Movement with right-wing League populists. At first glance, there is little in common between the two political forces, but weeks of intense negotiations have shown that ideological opponents can reach a compromise on key foreign and domestic policy issues. Their compromise was consolidated by a coalition agreement of fifty pages. It specifies, in particular, the desire of both parties to support the lifting of EU sanctions against the Russian Federation, as well as to refrain from restrictive measures in the EU economy. Another important agreement was that the party leaders did not apply for the post of Prime Minister Matteo Salvini (League) and Luigi di Mayo (5 Star Movement). As a result of the negotiations, the choice suddenly fell to little-known Florence law professor Giuseppe Conte - a man who had never worked in public office before. But the coalition did not last long. The crisis in the activity was the vote of the League together with the opposition for the construction of high-speed rail in France, this was contrary to the position of the Five Star Movement. In Italy, the populist Five Star Movement and the center-left Democratic Party have said they have agreed to form a coalition government. The parties have agreed that Giuseppe Conte will remain as Prime Minister.

Italy has only confirmed the trend: more radical rivals of the traditional parties are becoming an acceptable choice for Europeans who see in their populist slogans and promises an alternative and novelty. Europeans expect simple solutions from them for complex problems that have accumulated over the years.

Thus, we can conclude with an understanding of regional specificity that the most in-depth and comprehensive understanding of the complex mechanism of self-determination of Italians is possible only through the prism of the national-regional component.

18 Elezioni Politiche 2018. URL: .https://www.corriere.it/elezioni-2018/risultatipolitiche/camera.shtml?refresh_ce-cp 


\section{CONCLUSIONS}

Regions play an increasingly important role in geopolitical processes. Problems of regionalism are at the center of political life in many countries today.

Regional identities have their complex structure and dynamics, characterized by sub-regional cleavages within the very regional identities that are defined by the ethnic minorities formed in the process of immigration. In the context of globalization, the latter circumstance, especially in the sense of increasing in recent years the flow of immigrants from the Middle East and other regions of the world, contributes to the formation of various ethnic differences within the regional identities, which actualizes the problem of social and political consolidation in the devotional regions. Brexit, in turn, raised the question not only of "Britishness" in relation to regional identities, but also of the need for further constitutional changes in the country in the context of deepening devolution.

With regard to Italy, despite the large number of different separatist movements and their active activities, none of them succeeded in achieving the goals and bypassing the Italian constitution. It should be noted that the situation of national and linguistic minorities in the country cannot be called critical, since they represent their interests in the Parliament (both in the Senate and in the House of Deputies). Persistence in the actions of separatist movements is linked to their deep historical roots. A possible catalyst for movements could be the problem of influxes of refugees from the Middle East, as in the UK. The huge influx of migrants will worsen the socio-economic situation in the country, which will increase the number of supporters of various separatist movements. At some point, the central government may not keep the situation under control, and it is difficult to be sure that Italy will long be able to exist as a single state.

And finally, a positive point for the EU may be that Italian Eurosceptic populists do not put on the agenda the question of Italy's exit from the EU following the example of the British.

The very conventionality of Italian unity reduces the severity of the controversy between the Federalists and the Unitarians and guarantees that Italy's political passions will not reach the same level as in the United Kingdom. For Scots, Northern Irish, the struggle for secession is a matter of national-regional identity, not tax redistribution. In Italy, the attempts 
of individual regions to change relations with the center are mainly due to economic considerations, so a simple redistribution of powers in their favor will be sufficient to preserve the unity of the country, albeit on other federal grounds.

\section{SUMMARY}

This section of the monograph focuses on the consideration of identification processes within the framework of regional identity formation in the United Kingdom and Italy.

Comprehensive analysis of the components that form regional (national-regional) identity in Italy and the United Kingdom has been carried out. The study takes into account the context of both the historical legacy and the current globalization processes, which undoubtedly play an important role in constructing a model of regional identity of any state.

Within the framework of political decentralization in both the UK and Italy, a devolution model has been implemented, the content and features of the current stage of devolution in these countries have been revealed, the essence of which is to choose a model and political strategy for the transition to a larger-scale strategy of expanding the sphere of selfgovernment of regions and their participation in the adoption. political decisions.

It is shown that the factors of globalization, European regionalization have a stimulating influence on the development of the system of state management of socio-economic development of both the state and its ethnic regions.

The attention was paid to the presence of separatist movements in these countries, the main reasons for their development and the level of influence on the present political space of the studied states were determined.

\section{REFERENCES}

1. Баранов А.В. Сепаратизм в современной Италии: факторы развития, институционализация, политические стратегии. Человек. Сообщество. Управление. 2015. Т. 16. № 12. С. 78-90.

2. Ерёмина Н.В. Факторы роста европейского этнорадикализма на примере Шотландской национальной партии и Североирландской партии «Шинн Фейн». Политическая экспертиза: ПОЛИТЭКС. 2010. T. 6. № 1. С. 179-189. 
3. Левин И.Б. Национальная идентичность в условиях глобализации (на материале Италии) // Новые тенденции во внутренней политике развитых стран. М., 2005. С.85-94.

4. Линтнер В. Италия. История страны. М., 2008. 372 с.

5. Моисеева Д.П. Валле-д'Аоста на перекрестке языков и идентичностей. Россия и Запад: диалог культур. 2015. № 8. URL: http://www.regionalstudies.ru/journal/homejornal/rubric/2012-11-02-2211-32/366 (Дата обращения: 23.05.2019).

6. Elezioni Politiche 2018. URL: https://www.corriere.it/elezioni2018/risultati-politiche/camera.shtml?refresh_ce-cp 25.05.2019).

7. English national identity. URL: http://www.walesonline.co.uk/ news/wales-news/rise-english-national-identity-threatening-4880115 (Accessed 03.04.2019).

8. EU funding in Wales. URL: http://gov.wales/funding/eufunds/2014-2020/?lang=en (Accessed 23.05.2019).

9. EU funding in Scotland. URL: http://www.parliament.scot/ ResearchBriefingsAndFactsheets/S5/SB_16-

89European_Union_Funding_in_Scotland_2014-2020.pdf (Accessed 25.05.2019).

10. EU grants to Northern Ireland. URL: http://www.newsletter.co.uk/news/business/where-do-eu-grants-tonorthern-irelandgo-1-7233873 (Accessed 21.05.2019).

11. Gerven W. Federalism in the US and Europe. ICL journal. 2007. Vol. 1. URL: http://www.internationalconstitutionallaw.net/journal.

12. Giorgia Bull and Filippo Tronconi. The elusive nature of the Lega Nord // Mapping the Extreme Right in Contemporary Europe: From Local to Transnational / Andrea Mammone, Emmanuel Godin, Brian Jenkins. Routledge, 2012. 344 p.

13. Hunt T. Labour must embrace Englishness // The Guardian. 5 February 2016. URL: https://www.theguardian.com/commentisfree/ 2016/feb/05/labour-embrace-englishness-proud-patriotism (Accessed 13.05.2019).

14. National identity and ethnicity in Scotland. ESRC Centre on dynamics of ethnicity. URL: http://www.ethnicity.ac.uk/medialibrary/ briefings/dynamicsofdiversity/code-census-briefing-national-identityscotland.pdf (Accessed 23. 05. 2019). 
15. Northern Ireland identity. URL: http://www.niassembly.gov.uk/ globalassets/documents/raise/knowledge_exchange/briefing_papers/series 4/northern_ireland_identity_garry_mcnicholl_policy_document.pdf (Acessed 16.05.2019).

16. The Implications of Devolution for England. http://www.gov.uk/government/publications (Acessed 17.05.2019).

17. Welsh identity. URL: http://www.ethnicity.ac.uk/medialibrary/ briefings/dynamicsofdiversity/code-census-briefing-national-identitywales.pdf (Accessed 10.05.2019).

\section{Information about the author: Rostetska S. I.}

Candidate of Political Sciences, Associate Professor of the Department of Political Sciences and Law, South Ukrainian National Pedagogical University named after K. D. Ushynsky 26, Starofrankivska str., Odessa, 65000, Ukraine 


\section{SOCIAL ENVIRONMENT OF HIGHER EDUCATION ESTABLISHMENT AS A SYSTEM-FORMING FACTOR OF PROFESSIONAL SOCIALISATION}

\section{Shaposhnykova I. V.}

\section{INTRODUCTION}

Postindustrial society attaches great importance to human capital, now it is more significant than natural resources and accumulated wealth. Person's abilities, his knowledge, skills in the conditions of new geopolitical and socioeconomic challenges are recognized as an asset for regular enrichment. The modern labor market is characterized by high competitiveness and significant dynamics. The available approaches to specialists' training do not allow higher education establishment graduate students to integrate with modern labor market requirements effectively. The low level of specialists' competitiveness and the necessity of their rapid integration into the corresponding profile of economic activity conditions predetermine the need for a radical revision of the system itself. At the same time, the quality and content of the students' curricula are secondary. At the forefront are issues of young specialist social maturity formation.

The solution to this problem is multidimensional, because modern world is characterized by a number of complex and contradictory social processes that not only changes the very social role of the of Educational Institution, but also social practices and mechanisms of human interaction. The multidimensional nature of the problem determines a wide range of researches, including related to the problems of youth socialization, its cultural formation, capitalization of acquired knowledge, and also related to the analysis of the contemporary value and normative status of native students.

This problem arises in two aspects: ontological and epistemological. The first one outlines the need for a specialist with a certain set of social, psychological and professional characteristics for a relatively long time, while the requirements for a particular type of professional activity are constantly changing. In fact, we are talking about a social modeling of the internships nature, adequate to the changing conditions of the information 
society. The second aspect, which provides a scientific explanation of the professionalization process' reasons and nature while studying in the higher education establishment, is rather fragmentary and requires systematic expansion and rethinking.

Therefore, the research relevance of the professional development and formation process is a simultaneous study of the individuals' capitalization selfish goals mechanism implementation and adaptive mechanisms of effective integration into the labor process' changing conditions. In fact, there is a public need to find out the possible variations in the process of professional formation and their reduction in accordance with the specific social and production conditions of the future specialist functional responsibilities.

Analyzing the professional development process from the point of various scientific fields, it should be noted that this development is quite systematically analyzed by different philosophical and sociological schools. So from a philosophical point of view, the study of the professional formation process is connected with the man entry into one of the basic spheres of human existence (the labor sphere). As a philosophy category, labor is a form of human world reflection, both physical and ideal. In this context there is a need to integrate these two aspects in a specialist- forming process. From the sociology of education point of view the attention should be paid to the aspects of the knowledge formation among university students as well as the process of social consciousness changes regarding the capitalization of graduates with higher education. In terms of labor sociology the scientific interest is the definition of a direct behavioral acts' nature that should be developed in students through education in accordance with the changing conditions of the labor process. Current issues of professional development arise in the context of future specialist further capitalization and management process during his employment.

\section{Higher educational institution as a professional socialization environment}

Getting sociological theoretical understanding of education quality and the individual's professionalism was described by classics, including E. Durkheim, M. Weber, G. Spencer, P. Sorokin, T. Parsons, K. Mangayym, G. Becker, T. Schultz. The problems of youth as a subject of social development are paid to the attention of such world-famous scholars as: 
E. Durkheim, R. Merton, T. Parsons, P. Sorokin. Consideration of cultural aspects of the professional formation (philosophy of life) - M. Haydegger (phenomenological aspects of the culture formation). In the process of interpreting social and cultural practices the great values are acquired by S. Freud, K. Jung (Freudism, Neo-Freudianism), M. Fuko, D.F. Liotar (structuralism and post-structuralism). The great importance in the study of educational process social and cultural aspects has the works by A. Zdravoimyslov, N. Skvortsov and others.

In the context of this study, higher education is seen as a factor in adapting to the individual's living space. This problem was investigated in social and philosophical writings by Yu. Habermas, O. Spengler, P. Berger, T. Lukman, A. Turin and others. Consideration of the social space as a medium of human interaction is found in the writings of G.Zimmel, P.Sorokin, P.Burdieu.

As professionalization is a part of personality forming process, the works by V. Lisovsky, A. Kovalyov, V. Yadov are studied. They examined aspects of socio-economic, spiritual and other aspects of personality formation.

General theoretical and sociological approaches to educational problems studying, its functional characteristics and values in public life are presented in the works of foreign and native scientists: I. BestuzhevLada, M. Rutkevich, F. Sherega, V. Ossovsky, E. Yakuba, etc.

The work of A. Onisimov, A. Osipov, E. Klimov, V. Shadrikov, A. Saveliev and others is devoted to the sociological model of a university graduates' formation.

A. Zdravomyslov, Zh. Toshchenko, G. Zborovsky, G. Cheredinichenko and others made a significant contribution to the study of individual's socialization and professionalization.

Among the famous researches a number of well-known scholars also worked on development and management of higher education including V. Astakhov, I. Gavrilenko, V. Gorodjanko, O. Skidin, M. Lukashevich, M. Rutkevich, V. Chepak, D. Shvets and others. The diversity analysis of the student youth social practices is devoted to a large number of works by our sociologists as: L. Aza, V. Arbenina, V. Bakirov, E. Golovakha, S. Makeev, B. Nagorny, V. Nikolaevsky, N. Pobeda, L. Sokuryanskaya, S. Oksamitna, L. Khizhnyak, A. Yakuba.

Despite considerable sociological developments in the field of professional development of young people, there was not enough 
attention paid to the issues of socio-technological aspects of the students' professionalization in the process of their training in higher education establishment.

Modern scientific sources include consideration of the "professionalization" category mainly to the psychologists' attention. In this case, this approach essentially narrows the problem field and does not allow establishing causal relationships in the process of professionalization between the individual and the reference group. The psychological approach determines the object-subject one to the consideration of the professionalization problem while, in our opinion, it should be correctly to discuss the subject-subject logic of the professionalization process.

The sociological sources also contain approaches to this phenomenon studying, however, for the most part, professionalization is appreciated from the valuation position. In our opinion, the modern pace of socio-economic processes determines the attention to the instrumental component of the process of professionalization, namely, the phenomenon of professionalization should act as an object of social design. We believe the current pace of socio-economic processes determines the attention to the instrumental component of the professionalization process - the phenomenon of professionalization should act as an object of social design.

Category "professionalization" is often used in scientific research literature to analyze problems of professions and professional activities, which is considered as an individual's specific condition. The term "professionalization" appears in the dictionary of the Ukrainian language, which is defined as the process of "mastering by any profession as their regular occupation; transition to professional ranks by which position causes a status, adequate remuneration and privileges." 1

A substantially different definition of the term "professionalization" is proposed in another encyclopedic dictionary: "a holistic continuous process of a specialist personality formation, beginning with the time of the future profession choice, and ending when a person ceases active labor activity." 2

${ }_{1}^{1}$ Словник української мови: в 11 томах. - Том 8, 1977. - Стор. 332.

2 Душков Б.А., Королев А.В., Смирнов Б.А. Энциклопедический словарь: Психология труда, управления, инженерная психология и эргономика / Б.А. Душков, А.В. Королев, Б.А. Смирнов. - «Академический проект, Деловая книга», 2005. - 848 с. 
Taking into account that social processes that take place within the higher education studies framework are aimed to form a student's professional readiness for a wide range of functional responsibilities, one should more clearly distinguish approaches to socialization and professionalization.

According to E. Durkheim the process of socialization is an "every minute feeling of ... the pressure of the social environment by the child, which seeks to form it in his way and has parents and teachers as his representatives and intermediaries." ${ }^{3}$ So, the artificial process of professional competence formation will coincide with socialization.

Another researcher, E. Erickson, imagined, with one hand, successful socialization as the process of acquiring the typical features that characterizes a society in which individual functions. On the other hand - giving a particular type of behavior by individual characteristics. E. Erickson "understood socialization both as an individual, and as a collective process, which is largely occurs through the mechanism of identifying the individual with the group, people, society.

Identity points to the involvement of the individual in the unique values of the people generated by his unique history, but this is the only one of a broader concept of the human life cycle, according to which socialization is a consistent process of individual deployment through known phase-specific psychosocial crises." ${ }^{4}$

Thus, the instrumental difference between socialization and professionalization in the process of a professional personality forming during his training is minimal. However, in order to identify the differences, we consider it expedient to continue the analysis of existing approaches.

Given the findings of the researcher V. Mansurov professionalization process is seen by the representatives of the sociology functional direction as a professional group's response to the needs of society. ${ }^{5}$ We consider it possible to further use the above thesis as a

3 Дюркгейм Э. Социология. Ее предмет, метод, предназначение / Пер. с фр., составление, послесловие и примечания А. Б. Гофмана.- М.: Канон, 1995.- 352 с. (История социологии в памятниках), с. 34.

${ }^{4}$ Рюль В.О. Дослідження феномену соціалізації в наукових концепціях розвитку особистості / В.О. Рюль // Науковий вісник Ужгородського університету : Серія: Педагогіка. Соціальна робота / Гредкол.: Козубовська I.В. (гол. ред.) та ін.]. - Ужгород: Видавництво УжНУ «Говерла», 2011. - Вип. 23. - С. 150-154. - Бібліогр.: с. 154.

5 Профессиональные группы: динамика и трансформация / Под ред. В.А. Мансурова. - М.: Изд-во Института социологии РАН, 2009. - 419 с. с. 22. 
dominant one, basing on the analysis logic principles of functionalism. However, the needs of society are also a very discrete. It demonstrates the inability to adapt professional future (in the process of professionalization) to the needs of society. Adaptation to the requirements of specific (target) groups is more correct.

Considering professionalization in the broad sense, we should refer to P.Sorokin's works. He outlined the channels of vertical mobility such as the army, the church, educational establishments (school), government groups, political and professional institutions, organizations which create the material values and the family. ${ }^{6}$

Professionalization is an integral factor of social mobility in each of the channels, since it capitalizes a graduates of a higher school on social needs at the present stage of social development, except the last social institution. Proceeding from the proposed logic, it is not the affiliation to a particular channel (participation in it), but social readiness (professionalization) ensures the social mobility. On the other hand, according to some authors, professionalization is a factor of mobility constraints. In our view, the existence of a connection between professionalization and social mobility predetermines the possibility of its content establishing different from the process of socialization. The essence of this difference is that socialization is a successful integration into a particular community (group) in order to ensure stability in society. In contrast, professionalization is a condition of social mobility, which, being similar to socialization by forms of influence on the individual, has fundamental differences in the social system.

Thus, the formation of an expert and the individual are closely connected. The formation of a professional/ expert is considered by some researchers as one of the developed forms of the individual in the unity of professional development and personal qualities in which the individual fixed idea about the ability of a particular activity.

It is clear that there are certain professional individual abilities regarding the functions of a certain type. In this sense, the individual (psychological) abilities, supplemented by the social ones, lead to the formation of a professional. The process of such an addition should be

6 Сорокин, Питирим Александрович. Человек. Цивилизация. Общество / Питирим Сорокин; [Общ. ред., сост. и предисл., с. 5-24, А. Ю. Согомонова]. - М. : Политиздат, 1992. - 542, [1] с.; 22 см. - (Мыслители ХХ века. Редкол.: Т. И. Ойзерман (пред.) и др.). 
objectified through a system of social institutes, one of which is the Institute of Education. In our view, it was its role in the professionalization of the individual is crucial, because the structure of the social institution begins targeted social impacts on the individual, during which his psychological competence to further the process of professional development are formed.

In view of the above, we believe that it is fundamentally important to proceed also from the psychological preconditions of the individual at the initial stage of professionalization, in particular:

a) every person, according to his individual qualities, first of all, with professionally significant abilities, most suitable for a limited range of occupations (professional functions);

b) professional success and satisfaction with the profession is determined by the degree of individual qualities conformity to the particular profession requirements;

c) professional choice is essentially a conscious and rational process in which an individual determines a personal disposition of psychological or physical qualities and correlates it with existing dispositions obtained during the other professions testing.

Closing basic principles of the professionalism and consideration in the process of basic psychological characteristics of the individual allows to specify the "professionalization" as individual life strategies. Thus, professionalization strategies, under which foreign researchers understand the group's upward mobility ${ }^{7}$, provide conditions for the implementation of individual policies rising.

Thus, the process of professionalization during university studies is a preparation to the process of entering into specific social roles, due to vertical hierarchy and professional workforce.

As T.Parsons noted, the professional roles outlined by typical careers vary substantially every time they move to a new career stage. It is here the one of the most important problems of adaptation related to the career beginning arises: in particular, from the low responsibility position, which becomes more and more accountable. The situation is changing, the person submits many at the beginning, and then becomes the manager of many people. It is known that such changes cause very severe stress,

${ }^{7}$ Профессиональные группы: динамика РАН, 2009. - 419 с и трансформация / Под ред. В.А. Мансурова. - М.: Изд-во Института социологии. 
but the fact remains that most people successfully overcome it without going through a complex process of learning ${ }^{8}$.

Thus, the role of an educational institution in the process of professionalization is fundamentally high, and the expediency of attention from social and technological positions is virtually indisputable. The above creates the preconditions for the formation and implementation of specific social programs and projects aimed at intensifying the process of professionalization in the social environment of higher education establishment at different levels, and is also a significant factor in the capitalization of the future professional.

\section{Professional self-determination in the labor socialization system}

The personal and professional formation of Ukrainian youth takes place in the difficult conditions of socio-economic transformation of society.

In the transition period there was a fundamentally new situation in which young people make their professional choices basing on unsteady occupational structure, lack of job security and the need to compete in the labor market. The above imposes a significant impact on professional choice logics. However, the most significant social processes that transform the choice of professional activity of contemporary Ukrainian youth can be:

Firstly, that there is an intensification of social differentiation, the emergence of "rich" and "poor". The more active this interaction develops in society, the more influential financial status becomes. It determines the level of harassments, educational and professional intentions and youth life strategies.

Secondly, market transformation have led to hopping popularity of new professions that serve the market economy (manager, advertising and lending specialist, banker), partly due to the public attention to entrepreneurship.

Thirdly, the formation of active youth self-determination, independent choice of professional activity and funds investment in obtaining a profession takes place as a result of the state refusal to control the sphere of professional guidance. Relevant processes are inherent not

${ }^{8}$ Парсонс Т. О социальных системах / Под ред. В.Ф. Чесноковой и С.А. Белановского. - М.: Академический проект, 2002. - 832 с., с. 350-351. 
only for young people who first acquire education, but also for those who are focused on continuous retraining. However, in this case, the risk of error in professional choice and material loss increases.

Fourth, the lack of centralized planning and redistribution of graduates complicates the process of young professionals' employment, which negatively affects the vocational guidance process, but at the same time increases its importance, since the correct choice of profession, taking individual abilities, significantly increases the chances of effective competition.

Fifthly, the lack of priority sectors of the national economy development, the crisis of leading industries, and the under financing of science, culture, education creates difficulties in professional selfdetermination because of the difficulties in understanding promising professions (specialties).

Market and postmodern transformations have caused the displacement of the young generation values, including the value of labor. Work began to be perceived by young people as instrumental value "source of income". This installation reflects the formation of a new "market" labor and consumer ethics. Such ethics does not contain, in our opinion, a fundamental negativity, but its formation as a holistic cultural phenomenon requires a certain period of time longer than the one that has passed since the independence of Ukraine.

Realizing this, it is relevant to study the features of modern students as a social group, its problems and the degree of professional choice awareness. Given the social significance of this group, the solution of the outlined problem can be illuminated by analyzing the formation mechanisms of students professional orientations and thus become an important theoretical and informational basis for determining the optimal ways of its primary labor and further professional socialization in the system of higher education, as well as the implementation of the initial stage of such socialization - provision of youth professional guidance (both in the process and before the beginning of education in the university).

The solution to this problem led to the organization and implementation of an empirical sociological study by the author in 20162017. It was aimed the identifying features of social and professional orientations and student plans. The study covered 544 students of the Kherson region higher educational establishments. The different types of 
universities, specialties and students are represented in a quota and proportional sample.

The full-time students of Kherson region higher education establishments were selected as the study direct object. The study subject was the professional orientation of students.

The general research purpose was to study the peculiarities of the Kherson region students' professional orientations in order to identify the main areas improvement of the youth professional orientation work system in the region.

Just this research allows to solve a range of problems related to the definition of students' professional choice as:

- to establish the reasons of higher education obtaining and just the specialty;

- to outline the influence of different social agents on the students' professional

- orientation;

- to identify the attitude to the education quality;

- to identify factors of educational establishment choosing;

- to identify contradictions in obtaining a profession;

- to outline the chances of getting a job;

- to study the professional plans of graduate students from their orientation to

- work by specialty point of view;

- to find out the factors that influence the particular job choice;

- to identify the factors that determine the students' professional choice;

First of all, we have identified the reasons why students choose the specialties they are studying. The research shows that among the most attractive aspects of the chosen profession, students note the following: the prestige of the profession is $45.1 \%$, the creative nature of the work is $41.6 \%$, and the broad range of communication is $40.3 \%$. It should be noted that high wages are on the fifth place $-32.4 \%$. That can be said about the dominance of socially-oriented values when selecting a particular profession without the real situation on the labor market (only $16.4 \%$ of respondents pointed "easy to find work in the specialty").

The study results indicate that the greatest influence on students' choice has closest environment - parents and relatives $(59.3 \%)$. In addition, the influence of is increasing (39.3\%). At the same time, schools 
and centers of professional guidance have a much less influence (23\% and $16.5 \%$ appropriately).

This shows that in the absence of a full-fledged state professional guidance system, presented by educational and public institutions working with young people, the formation of professional youth benefits occurs spontaneously, without real trends in the labor market, mainly within the family. The emotional destiny is significantly serious in the future profession choice, characterized by media influence level.

Thus, this confirms the need of systematic work with youth at the early stage of its professional formation to ensure its effective entry into working life, taking the trends of socio-economic development of society and a specific region. An average family is almost unable to solve this problem independently.

According to our research, most parents of students have a high educational level (higher education $-38.7 \%$, secondary specialty $46.5 \%$, only $5.9 \%$ have a full secondary education). These are the persons who predominate in the technical and creative intelligentsia, civil servants, and entrepreneurs who occupy a sufficiently high position in their profession (47.4\% are heads of different levels in the organization or private entrepreneurs, $18.3 \%$ are specialists, $29,8 \%$ - the working class).

It is clear that these people have both developed motivation and more financial capacity, which allows to give their children higher education (even paid education). Thus, studying at universities can be considered as a mechanism for the parents' social status transfer to children and "vocational guidance" for higher education obtaining as a copy of the parents' life model, which is typical for families with a high social status.

Certain interest is the students' attitude to the quality of education. Among the reasons for the dissatisfaction with the level of education noted the following: lack of qualified teaching staff $-38.2 \%$, lack of fulltime internship at the enterprises $-32.6 \%$, unsatisfactory material and technical base $-25.3 \%$.

An effective combination of students' theoretical training and practical mastering of the profession during the educational process is a typical problem for Kherson as well as the whole country in our opinion. Higher school today does not fully perform its assigned function training of highly skilled professionals for the national economy. It also does not provide training in the social experience necessary to compete effectively in the labor market. 
According to our research, in the process of choosing a university, respondents were influenced by the following factors: the advice of relatives and friends $-32.6 \%$, high prestige of the university $-22.2 \%$, accident and coincidence $-16.8 \%$.

It is important to analyze the reasons that affect the attractiveness of universities. Thus, higher education attracts students with the opportunity to "obtain the necessary for professional activity knowledge" (73.4\%), "to reveal their intellectual qualities" (61.2\%), "to receive a higher education diploma" (58.5\%), as well $39.6 \%$ of respondents noted the possibility of interesting communication. This gives rise to talk about intellectual and pragmatic motivation of students for their studies at universities, the result of which must be both objective (diploma) indicators and subjective (specific knowledge) indicators, which together give some competitive advantages in the labor market.

However, some of these factors are not enough to be a competitive specialist. As our research shows, $40.6 \%$ of the polled students are forced to make extra money in their free time. At the same time for $16,9 \%$ - it is an opportunity to get a professional experience which is do necessary for successful employment.

The combination of study and work is a widespread practice for most of today's Ukrainian students. For $85.4 \%$ of the number of working students - it is necessity earnings for different needs. It is mainly forced employment and it is related to the need to keep oneself in the training period. For many students, extra earning is relevant just as a means of paying tuition (the data said $-64.5 \%$ of students study on a commercial basis).

It should be noted that $39.3 \%$ of students work more than 20 hours a week, $30.6 \%$ up to $10-20$ hours. These figures generally indicate a rather large employment of working students. Of course, this can not but affects their success and professional training. However, only $26.7 \%$ of respondents felt that employment negatively affects their performance, and $54.9 \%$ said no effect, and $18.4 \%$ of students believe that their secondary occupation positive impact on performance. In this case, $50.3 \%$ of students associated part-specialty with the major at university and $13.5 \%$ of students are working to get more ideas about the profession in practice. This fact is evidence of a "compensatory" function of secondary employment, which allows a student, in a poorly organized educational process, to acquire the professional knowledge and skills necessary for successful work. 
Therefore, we tried to identify the existing contradictions in professional plans of students, causing expression of supply and demand imbalance in certain type of human resources.

So, in general, $46.5 \%$ of students want to work in the specialty ( $18.1 \%$ would not like), while $10.3 \%$ would like to continue their studies in the chosen specialty. At least $18.1 \%$ of respondents are aware that they will not work in their specialty, that is, almost one of five students are in vain gaining knowledge of their profession, because their subsequent work will not use them. At the same time, these students spend their material and time resources irrationally, what can negatively affect their social capital formation.

In charge of the chances to find a job in the specialty after graduation, $53.7 \%$ of which there is a chance, $31.3 \%$ said that the chances are small, and $1.2 \%$ noted item "virtually no chance". Thus for successful employment, according to students, we must first have: real knowledge, skills and abilities $(62.3 \%)$, the labor market need in this profession $(59.7 \%)$, experience $(58.5 \%)$.

Guaranteed job will have $18.7 \%$ of respondents, $27.7 \%$ of students said that no and $53.6 \%$ could not answer the question. This indicates that the employment problem is students directly. In addition, the hypothesis of no interaction between higher education establishments and manufacturing organizations in the field of training is confirmed. That is in spite of the fact that employers have a need for qualified specialists, but they do not do specific university orders.

According to the results of the survey, the loss of confidence in existing institutions by the students regarding the ability to find a job in a specialty was confirmed (only $21.5 \%$ of the students counted on the help of the recruiting agencies). Given the complexity of finding a job related to lack of work experience, competition in the labor market, getting work is a top priority for the graduate. According to the results of the survey, the loss of confidence in existing institutions by the students regarding the ability to find a job in a specialty was confirmed (only $21.5 \%$ of the students counted on the help of the recruiting agencies). Given the complexity of finding a job related to lack of work experience, competition in the labor market, getting work is a top priority for the graduate. At the same time, as our study shows, student youth is oriented not on the possibility to work in a specialty with the purpose of 
employment, but on the socio-occupational benefits provided by a potential organization-employer.

Research shows that students focus on factors such as high wages (79.8\%), prospects for career growth $(76.5 \%)$, creative nature of work (46.9), social benefits and guarantees that is provided by the organization $(38,2 \%)$, the prestige of the organization $(34,9 \%)$. Only $27.1 \%$ chose to work in a specialty. This fact may indicate that the student during a job search is oriented towards stable organizations where well-paid work and career prospects are in progress, whereas professional specialization is of secondary importance.

If we analyze the level desired monthly payment, then $41.1 \%$ of students expect wages to 5,000 thousand UAH., and only $12.4 \%$ - from 7000 thousand UAH. Therefore, in general, we can diagnose the objective level of student's desired wages. Importantly, almost half of students $(49.1 \%)$ chose to work in state enterprises, $22.3 \%$ of students want to work for private enterprises and only $1.8 \%$ - in social organizations.

In other words, the results confirm that work in a private enterprise in a market economy is risky in terms of possible non-compliance by the employer with the norms of labor legislation, lack of social guarantees, uncertain prospects for personal professional development. So:

- most of the students targeted for "fashionable" professionals without their own abilities to the profession, interests;

- when choosing the future profession, young people are guided primarily thought of family members and relatives, while school and vocational guidance centers slightly influence the choice of future students;

- there is some emotion when choosing a specialty in higher education, as evidenced by significant influence of media on youth vocational guidance;

- in choosing a particular specialty, young people are guided primarily by factors such as prestige, creative professions, as well as the possibility of a wide range of communication;

- $40,6 \%$ of students are forced to work, the reason is the need for financial independence, as well as the desire to gain experience in the specialty;

- only $46.5 \%$ of students plan to work in the specialty after graduation (10.3\% want to continue their studies in the field); 
- every fifth student makes an irrational professional choice because he is not focused on work after a graduate degree;

- most students will not have a guaranteed post-graduate job, and when looking for a job they are focused mainly on self-help or help from friends (while the focus on employment assistance and recruitment agencies is not significant);

- in determining the future place of work, the key factors for students are high wages, career prospects, interesting work, social guarantees and prestige of the organization, while the opportunity to work in a specialty is of secondary importance;

- almost half of students want to work at enterprises of state ownership.

\section{CONCLUSIONS}

Now we can conclude that the social environment of a higher educational establishment is a powerful factor in the students' professionalization. It is the process of higher education obtaining that can be considered as an important contribution to a future specialist capitalization. This is confirmed by the findings of research on students' professional orientation of Kherson universities.

The social and cultural environment of higher education establishments creates all conditions for raising the level of students human capital in different fields contributes to the formation of future specialist critical thinking and develops the ability to use the acquired knowledge.

However, we can state that the analysis made it possible to find out that in the process of professional choice and professional orientation, which occupy a significant place in the modern system of training skilled personnel in Ukraine, there are a number of shortcomings. They are mostly derived from the general culture of society, as they are the results of the transformations of the values and normative orientations of modern society.

Today the prestige of the profession is not associated with its social value, but with the level of income that relevant professional activity provides. Everything mentioned above causes some deformation of labour orientations and professional values of future specialists. 
In addition, a basic requirement of modern employers is the need to ensure a higher level of professional adaptation to performing their professional functions. Under such circumstances, the only way to satisfy the current requirements for future employees is their social adaptation (as an ideal condition - their socialization) to future professional careers. Usually responsibility for the unsuccessful integration process is put on the social institution of education that does not provide sufficient conditions for the implementation of professional opportunities of young people (giving substandard knowledge, does not provide the quality of practice, etc.), prevents their selfrealization, thus contributing to its social exclusion.

The process of unsuccessful professional socialization and adaptation, which may result in a process of social exclusion, also deserves careful research attention. In this case, the appropriate exception can occur not at public, but at the professional level, which encourages young people to move away from the professional activities of a certain kind imitating professional search, or to attempt to put in other professional community (both occur fairly often). In this context, the general cultural capital of a society is gaining momentum. It will ensure the transformation of the value and regulatory structure of its members in accordance with the realities of social development. The last thesis is particularly relevant in the field of students' preparation for work.

\section{SUMMARY}

The article is devoted to the actual problem of professionalization of future graduates of higher education establishment. It is noticed, the low level of specialists' competitiveness and the necessity of their rapid integration into the corresponding profile of economic activity conditions predetermine the need for a radical revision of the system itself. The multidimensional nature of the problem determines a wide range of researches, including related to the problems of youth socialization, its cultural formation, capitalization of acquired knowledge, and also related to the analysis of the contemporary value and normative status of native students. This problem arises in two aspects: ontological and epistemological. Therefore, the research relevance of the professional development and formation process is a simultaneous study of the individuals' capitalization selfish goals mechanism implementation and 
adaptive mechanisms of effective integration into the labor process' changing conditions. In fact, there is a public need to find out the possible variations in the process of professional formation and their reduction in accordance with the specific social and productive conditions of the future specialist's functional duties. The above creates the formative and implementing preconditions for the specific social programs and projects aimed to intensify the professionalization process in the higher education establishment's social environment at different levels, and is also a significant factor of the future professional's capitalization. Stated that the period of transformation occurred fundamentally new situation in which young people make their professional choices based on unsteady occupational structure, lack of job security and the need to compete in the labor market. The above imposes a significant impact on professional choice logics.

\section{REFERENCES}

1. Словник української мови: в 11 томах. - Том 8, 1977. C. 332.

2. Душков Б.А., Королев А.В., Смирнов Б.А. Энциклопедический словарь: Психология труда, управления, инженерная психология и эргономика / Б.А. Душков, А.В. Королев, Б.А. Смирнов. - «Академический проект, Деловая книга», 2005. - 848 с.

3. Дюркгейм Э. Социология. Ее предмет, метод, предназначение / Пер. с фр., составление, послесловие и примечания А.Б. Гофмана.- М.: Канон, 1995.- 352 с.- (История социологии в памятниках), с. 34.

4. Рюль В.О. Дослідження феномену соціалізації в наукових концепціях розвитку особистості / В.О. Рюль // Науковий вісник Ужгородського університету : Серія: Педагогіка. Соціальна робота / [редкол.: Козубовська І.В. (гол. ред.) та ін.]. - Ужгород: Видавництво УжНУ «Говерла», 2011. - Вип. 23. - С. 150-154. Бібліогр.: С. 154 (18 назв).

5. Профессиональные группы: динамика и трансформация / Под ред. В.А. Мансурова. - М.: Изд-во Института социологии РАН, 2009. -419 c.

6. Сорокин, Питирим Александрович. Человек. Цивилизация. Общество / Питирим Сорокин; [Общ. ред., сост. и предисл., с. 5-24, А.Ю. Согомонова]. - М. : Политиздат, 1992. - 542 с. 
7. Профессиональные группы: динамика и трансформация / Под ред. В.А. Мансурова. - М.: Изд-во Института социологии РАН, 2009. - 419 c.

8. Парсонс Т.О социальных системах / Под ред. В.Ф. Чесноковой и С.А. Белановского. - М.: Академический проект, 2002. C. 350-351.

Information about the author: Shaposhnykova I. V. Doctor of Sociological Science, Dean of the Social and Psychological Faculty, Kherson State University 27, Universytetska str., Kherson, 73000, Ukraine 


\section{UKRAINE IN THE CONTEMPORARY GEOPOLITICAL SPACE: TRENDS, RISKS AND THE CRISIS OF CHOICE}

\section{Shchedrova H. P.}

\section{INTRODUCTION}

Contemporary geopolitics is characterized by the gradual domination of the political factor over the geographical factor, the increasing number of geopolitical actors, the fragmentation of international connections and relations, and the crisis prevention priorities that shift from the economic sphere to the security sphere. These aspects have affected Ukraine as well, which, albeit with varying intensity, had made its way into the global community since the moment it gained independence in 1991. The same period saw the beginning of Ukraine's inclusion as a sovereign state in the scientific analysis of the political world. Given its specific geographical location, Ukraine has always been and will remain a priority area of research in political geography and geopolitics. Classical theories based their interpretations of Ukraine on the interests of the influential global states; however, the development of the political sphere in our country has led to a shift in the direction of research - from "one of the countries of the post-socialist bloc" to "a country in the center of Europe."

In contemporary political science, Ukraine as a research subject provides enough reasons not only for contextual exploration as a part of studying the region or the zones of influence of geopolitical actors, but also for the analysis of internal political processes within our country, which result from or determine the course of international politics. Thus, the problem of Ukraine's geopolitical position is a focus of attention both for national researchers and for the leading scholars of the contemporary geopolitical concepts. Ukraine has been studied by Anthony Giddens and Roland Robertson in the context of globalism and glocalism; by Immanuel Wallerstein as a part of the world-systems analysis; by Jacques Attali and Francis Fukuyama within the neomondialism framework; by Paul Wolfowitz and Samuel P. Huntington from the perspective of neoAtlanticism; by Zbigniew Brzezinski from the perspective of the contemporary Anglo-American geopolitical school; by Aleksandr Dugin in the context of Eurasianism, etc. Despite the significant attention of 
scientific schools to the geopolitical transformations that involve Ukraine, as of today, a concentrated geopolitical model that would take into account both the internal potential of our country and the current conditions of the external political environment is still missing. In addition, the contemporary global politics with its determined priorities on the European continent provides us with an opportunity to make a certain generalization about the geopolitical nature of Ukraine.

Classic geopolitical trends - Atlanticism and mondialism continued with the corresponding neo-concepts which were substantiated as doctrines by contemporary authors, mostly from Western research schools. Other integral theoretical components of modern geopolitics are the concepts of contemporary Eurasianism, globalism, glocalism, and the world systems approach.

Beside the conceptualization of the Ukrainian factor in geopolitics, the questions of Ukraine's own geopolitical choice, its risks and its crisis potential also remain important. We need to comprehend not only on the concept of «geopolitical choice», but also the actualization of its contents beyond foreign policy or orientation, since we believe that these concepts are not essentially identical. It is important here to analyze Ukraine's path from attempts to regulate its foreign policy strategy and to personify the vision of its prospects of foreign partnership, from multiple attempts to determine the vector of its foreign policy, and towards formulating the state's actual geopolitical choice while taking into account the public opinion and the national interests.

The recent developments, with the turning point in 2013-14 and the unfolding of military events in the East of the country, have proved that the local-regional coordinates of Ukraine coincided in time and concurred with the interests of other global players, which subjected the country's roles to the more influential actors of the global politics. That is why the important research tasks are to determine both the place of Ukraine in contemporary geopolitics and the risks that accompany the state's external integration at a transitional stage in its development.

\section{Ukraine's Place in the Contemporary Schools of Geopolitical Concepts}

The modern stage of geopolitical research is characterized both by Ukraine's inclusion in the systemic scientific studies of the course of international politics and by the expanding subject field of theoretical 
concepts that take into account the transformation of the place and role of the Ukrainian state in the course of cross-border and global processes. In retrospect, the catalysts of these changes in political science were the collapse of the Soviet Union and Ukraine's search for optimal foreign policy strategy, which was not without internal contradictions and external pressure.

Neo-Atlanticism was enriched by the relevant features of cultural and religious identity, which in Samuel P. Huntington's interpretation represent the civilizational markers. In his original 1993 essay The Clash of Civilizations, the American researcher claimed that cultural fault lines would provide a constant source of conflict. ${ }^{1}$ This paper, which was later expanded into a book, identified Ukraine as a prototypical «cleft country», where Ukrainian and Russian-speaking populations co-exist, doomed to suffer. Samuel P. Huntington predicted that Moscow's foreign policies will aim to consolidate the whole Orthodox Christian community with Russia at its core. The theory emphasized the missionary purpose of uniting ethnic Russians scattered across all former Soviet republics ${ }^{2}$. In the context of the events in Eastern Ukraine, contemporary researchers emphasize that separatism and the threat of annexation of territories, predicted by Huntington in his time, are «a page in the Kremlin's playbook» ${ }^{3}$.

However, one of the most important factors that externally affect the processes in Ukraine, according to Samuel P. Huntington, is the civilizational dividing line in Europe, on which Ukraine is located. "This line runs along what are now the boundaries between Finland and Russia and between the Baltic states and Russia, cuts through Belarus and Ukraine separating the more Catholic western Ukraine from Orthodox eastern Ukraine, swings westward separating Transylvania from the rest of Romania, and then goes through Yugoslavia almost exactly along the line now separating Croatia and Slovenia from the rest of Yugoslavia», he says in The Clash of Civilizations ${ }^{4}$.

${ }^{1}$ Huntington S. The Clash of Civilizations. Foreign Affairs. Touchstone, 1993. URL: http://online.sfsu.edu/mroozbeh/CLASS/h-607-pdfs/S.Huntington-Clash.pdf.

2 Huntington S. The Clash of Civilizations and the Remaking of World Order. Harvard University Printed, 1996. URL: http://www.academia.edu/4610592/Samuel_ P_Huntington_The_Clash_of_Civilizations_and_the_Remaking_of_World_Order_1996.

${ }^{3}$ McKew Molly K., Maniati Gregory A. Putin's global ambitions could destabilize Europe. The Washington Post. March 18, 2014. URL: https://www.washingtonpost.com/ opinions/putins-global-ambitions-could-destabilize-europe/2014/03/18/69abb2a2-aec511e3-9627-c65021d6d572_story.html?utm_term=.84f30a2d8c78

${ }^{4}$ Huntington S. The Clash of Civilizations. Foreign Affairs. Touchstone, 1993. URL: http://online.sfsu.edu/mroozbeh/CLASS/h-607-pdfs/S.Huntington-Clash.pdf. 
A significant and distinguishing feature of Huntington's theory is the recognition of Ukraine as a country with certain civilizational - cultural, linguistic, religious - authenticity. Thus, Ukraine emerged not as a passive participant (or a hostage) of the global politics of influential actors, but as a party in the geopolitical process that has its own interests. An important clarification built into Huntington's theory is the consolidating value of civilization. That is, if civilizations as such do indeed exist, then in the case of the conflict between Ukraine and Russia this will become a restraining and moderating factor in the neutralization of the confrontation.

Paul Wolfowitz, another representative of neo-Atlanticism, developed one of the most influential concepts of US foreign policy at the time, which was dubbed the «Wolfowitz Doctrine». And although it was mostly about arguments justifying the United States domination in the postwar world, it still assigned an important role to the peaceful coexistence of the countries of the former USSR. "The U.S. has a significant stake in promoting democratic consolidation and peaceful relations between Russia, Ukraine and the other republics of the former Soviet Union», reads the doctrine. ${ }^{5}$ Wolfowitz wrote that the joint forces of the post-Soviet states "retain[ed] the most military potential in all of Eurasia." At the same time, the politician did not rule out that Russia might attempt to reincorporate the territories of the new independent states.

The neoconservative branch of classic Atlanticism was developed by Zbigniew Brzezinski, a representative of the Anglo-American school of geopolitics. The researcher did not only pay significant scientific attention to the problem of Ukraine from the global perspective, but also participated in active advocacy for our state in the context of the Revolution of Dignity events and the Donbas confrontation that followed. Back in the late 1990s, in his book The Grand Chessboard, Brzezinski described the unique role of Ukraine in the development of the postSoviet space; he said that the awakening of Ukrainians was the main piece of evidence for the imperial domination of a foreign nation (the Russians) ${ }^{6}$. Agreeing in part with Samuel P. Huntington, the researcher recognized that Ukraine, together with Azerbaijan, South Korea, Turkey

${ }^{5}$ Wolfowitz P. Defense Planning: Guidance. URL: https://www.archives.gov/files/ declassification/iscap/pdf/2008-003-docs1-12.pdf.

${ }^{6}$ Бжезінський 3. Велика шахівниця. Львів-Івано-Франківськ : Лілея-НВ, 2000. С. 9. 
and Iran, carried the role of a geopolitical axis that should soon develop the characteristics of geostrategic activity. His arguments supporting the important role of Ukraine in the Eurasian space are exhaustive and have been tested by the contemporary history.

In one of his last studies, Strategic Vision: America and the Crisis of Global Power, Zbigniew Brzezinski dedicated a whole chapter to Ukraine. And although the book was published back in 2012, its predictive value was confirmed by the further development of nation-building in Ukraine. Brzezinski states that Ukraine tends to support European values, and that Russia's relationship with Ukraine since Ukraine gained independence in 1991 had been prone to tension, just as its relationship with the West. The author emphasizes that Russia uses energy as an effective means of influencing and pressuring Ukraine into supporting policies that benefit the Kremlin. The political researcher highlights that the Russian Federation constantly tries to subjugate Ukraine, as it did with Belarus, but that it can only succeed in this "assuming America's decline [and] a passive European response ${ }^{7}$. Brzezinski's recommendations are, first of all, to have a dialogue (between Russia and the Atlantic West) and to implement consistent democratic reforms (in Ukraine and other countries of the former socialist bloc).

The tendencies of the transition from mondialism to its updated form of neomondialism are defined in the works by the American political scientist Francis Fukuyama and the French researcher Jacques Attali. Both of them wrote about a drastic shift in geopolitical paradigms which imply that global domination must be based solely on the criterion of economic progress and innovation which will ensure the survival of the civilization. One of the key differences between the two authors is their attitude to the concept of "the end of history." While for Francis Fukuyama it is the final destination of the humanity's ideological evolution and the universalization of Western liberal democracy as the final form of governance for the human society, ${ }^{8}$ for Jacques Attali it is the inevitable conflict between the old and the new order. ${ }^{9}$

${ }^{7}$ Brzezinski Z. Strategic Vision: America and the Crisis of Global Power. New York, 2012. URL: https://orientalreview.org/wp-content/uploads/2012/12/Brzezinski-Zbigniew.Strategic-Vision-America-and-the-Crisis-of-Global-Power.pdf.

${ }^{8}$ Fukuyama F. The End of History? The National Interest. 1989. № 16. P. 5.

${ }^{9}$ Attali J. Lignes d'horizon. Paris, 1990. 216 p. 
Fukuyama's first studies had only contextual relevance to Ukraine's problems; however, nowadays the American researcher does not only comment on the course of the political process in our state, but also makes appearances at educational events in Ukraine. In the period between 2016 and 2019, Francis Fukuyama gave a number of extended interviews to the leading Ukrainian media, and in spring 2019 in his comment to the Atlantic Council think tank the scholar emphasized once again the significant role played by Ukraine in Europe. "It is both a symbolic and a geopolitical role that makes Ukraine much more important than other post-Soviet or post-communist countries. It tried twice to break with its Soviet past, with its authoritarian, kleptocratic neighbor... The Russians perfectly understand how important it is that Ukraine does not become successful. Ukraine's success is creating a democracy with actual competition in politics or making order in its leadership", emphasized Francis Fukuyama ${ }^{10}$.

For the leader of neomondialism, Ukraine is an example of cohesiveness of an active community capable of becoming a driver of state-making. However, in Fukyama's opinion, without foreign support, the civil society in Ukraine becomes more passive and loses its mobilizing power.

An opposite opinion is proposed by the French expert Jacques Attali in his coverage and perception of the Ukrainian issue. He believes that it is wrong to use Russia's annexation of Crimea as a pretext for a confrontation between Europe and the Russian Federation. "We have never approved of the current Russian regime or of its international strategy. I'm talking about the West, and more precisely about Europe. And, for me, the interest of Europe is not to engage in a confrontation with Russia. On the contrary, we have to do everything to integrate our large Eastern neighbor into the sphere of the European law", wrote Attali in his personal blog in March 2014. ${ }^{11}$

The French researcher draws long-term historical analogies with similar situations in the EU countries, emphasizing that the right to self-

10 Френсіс Фукуяма: Україна грає величезну роль в Європі у всіх сенсах Atlantic Council. URL: https://zik.ua/news/2019/05/14/frensis_fukuyama_ukraina_ graie_velycheznu_rol_v_yevropi_u_vsih_sensah_1570941.

${ }^{11}$ Attali J. Ukraine: sont ils tous devenus fous? URL: http:// marcrousset.over-blog.com/ article-ukraine-sont-ils-tous-devenus-fous-selon-jacques-attali123114753.html. 
determination is considered to be one of the most inviolable European values. Thus, from the perspective of this self-determination, he also does not separate Ukraine, particularly the residents of Crimea, from the European community with all the rights that it possesses. These claims were not widely supported among the diplomats of the Old Europe, because the annexation of Crimea was the beginning of a long period of military aggression in Eastern Ukraine, which is still considered to be one of the greatest tragedies of the European civilization in the 21st century.

The contemporary concept of Eurasianism (neo-Eurasianism), which has been interpreted in the context of studying the role of Ukraine in international politics by Aleksandr Dugin, the founder of the contemporary Russian school of geopolitics, can be considered a polar opposite of the concept analyzed above. For Dugin, Ukraine is one of the fronts of the "Great War of Continents", that is, the war between Atlanticists and Eurasianists. ${ }^{12}$ The Russian researcher defines several scenarios for the contemporary Ukraine:

- federalization of the state by conducting a referendum;

- splitting Ukraine into two states;

- preserving the unified Ukraine (without Crimea) on the condition that it supports the Eurasianist policy - that is, the policy of the Kremlin.

We must note that none of Aleksandr Dugin's predictions manifested in real life. In turn, the author never established Ukraine's ideological and mental belonging to the Eurasian pole. The only thing that was substantiated in his theory was the particular interest of Eurasianists in gaining control over Ukraine.

Another component of the contemporary geopolitics is the concept of the globalized world that encompasses the spheres of the economy, education, cultural and informational development, and includes the political component, subordinating it to the modern conditions of globalization and globalism. The concept of "globalism" was first introduced into the scientific language in 1983 by the British researcher Roland Robertson. To clarify, in 1983, the author used the term "globality" for the first time in the title of one of his articles, ${ }^{13}$ and in

12 Дугин А. Началась Великая Война Континентов. Пражский Телеграф. 9 апреля 2014 г. URL: http://ptel.cz/2014/04/aleksandr-dugin-nachalas-velikaya-vojnakontinentov.

${ }^{13}$ Robertson R. Interpreting Globality. World Realities and International Studies. PA : Pennsylvania Council on International Education, 1983. P. 7-20. 
1985, he already provided a detailed definition of the concept of "globalization". Later, the researcher expounded the foundations of his concept of globalism in a dedicated study, where the term was defined as an interconnected system of political, ideological, economic, social, military and other measures that aim to establish at the global scale the domination of a certain socioeconomic, ideological doctrine. ${ }^{14}$

In one of his latest papers, Beyond the Discourse of Globalization, the founder of the concept of globalism considers the problem of Ukraine in the context of analyzing the crisis in Europe, which Robertson defined as a crisis of governance in search of new forms of world organization. "Europe, its allies, and its neighbours have drastically changed. I think here of such developments as a much more assertive Russia (under the authoritarian leadership of Putin), Russia's invasion of Ukraine, its annexation of Crimea and its ongoing threat to Baltic countries," the British researcher writes in his study. ${ }^{15}$ Ukraine, in our opinion, is considered to be an indicator of priorities which de facto demonstrate the negation of international law and disregard for ethical norms in the implementation of the good-neighborliness policy. In general, the conflict involving Ukraine in the center of Europe, from the perspective of the concept of globalism, has revealed a precedent when the global position did not manage to absorb the local one.

As we clarify the circumstances that came to hold Ukraine hostage in the globalized world, we should draw attention to the concept of glocalism, that is, the combination of globalization and localization in the development of the humanity. Roland Robertson himself, in his article European Glocalization in Global Context, characterizes Europe as the history of constant and multiple process of glocalization. The concept of glocalization in the case of Ukraine reveals the undeniable circumstances of the simultaneous spread of both global foreign policy strategies and local aspirations of particular social groups and pressure groups. Under these circumstances, state policies must have a certain set of alternatives and backup plans in case the international situation or the domestic confrontation escalates. We should note that under the current

${ }^{14}$ Robertson R. Globalization: Social Theory and Global Culture. Journal of World History. 1994. № 5/1. P. 159.

${ }^{15}$ Robertson R. Beyond the discourse of globalization. Glocalism: journal of culture, politics and innovation. 2015. № 1. P. 12. 
circumstances, Ukraine must take into account the ideological, the regional and the socioeconomic factors of glocalization.

The theses of the contemporary world-systems approach to geopolitics, pioneered by the American sociologist Immanuel Wallerstein, are equally relevant. The concept is based on the interregional and transnational division of labor which divides the world into core countries, semi-periphery countries and periphery countries. The leading Yale researcher has recently paid a lot of attention to the geopolitical processes related to Ukraine; moreover, our country has become the basis for Wallerstein's non-contextual research. In his article The Geopolitics of Ukraine's Schism, the scholar considers the question of determined influence on the course of political, and later also military scenarios in Ukraine, accusing the US of excessively intervening in European affairs, where Ukraine is "merely a convenient excuse... for a larger geopolitical division." "Let me therefore propose that Ukraine is merely a convenient excuse or proxy for a larger geopolitical division that has nothing whatsoever to do with its internal schism. What haunts [the US] is not a putative 'absorption' of Ukraine by Russia... What haunts [them] is a geopolitical alliance of Germany/France and Russia," claims Immanuel Wallerstein in his article. ${ }^{16}$ In addition, the author emphasizes the difficulty of choosing a strategic partner for Ukraine - between the European Union and the Russian Federation - in the circumstances of relatively equal support for both vectors of diplomatic orientation among the country's population.

Immanuel Wallerstein rules out the bipolar influence on Ukraine by only the US and the Russian Federation, and he also studies the role of contemporary Germany in this. We consider it necessary to note here that Wallerstein's world-systems paradigm in this context partially overlaps with the established opinion of the global diplomatic community about the situation in Ukraine. For example, the researcher calls the conflict in Eastern Ukraine a "quasi-civil war," and believes that the key actors who can positively affect the resolution of the military situation are Germany and the Russian Federation.

Tellingly, Ukraine features in the majority of the conceptual theses of the world-systems theory, but is left out of the key categorization of

${ }^{16}$ Wallerstein I. The Geopolitics of Ukraine's Schism. URL: https://www.iwallerstein.com/geopolitics-ukraines-schism. 
the countries into the core, the periphery and the semi-periphery. Given the essential features of the three types of states as defined by Immanuel Wallerstein, Ukraine at the present stage occupies an interstitial space between the periphery and the semi-periphery, because it still plays the role of a resource base for the so-called "world-economies"; however, its gravitation towards European values gradually causes it to depart from passive geopolitical participation.

Based on the analysis we conducted, we can argue that Ukraine today is one of the geopolitical centers which, due to its geographic location and intrinsic potential, and its social and resource-industrial potential in particular, affects the diplomatic priority-setting among the leading political actors on the international arena. An important aspect of this proposition is Ukraine's current departure from passive participation in the geopolitical process and the changes in our state's foreign advocacy that took place in late 2013 and early 2014.

We must note that Ukraine does not get the proper opportunities to realize its interests on the international map under the domination of any of the geopolitical concepts which we reviewed here. This is predicated on both the historic development of our state, which mostly took place in the conditions of subjugation and dependence, and on the incoherent and sometimes even contradictory strategies of realization of its foreign policy course. Therefore, one relevant task today is to construct a geopolitical model that would take into account the internal potential, needs and interests of Ukraine. In our opinion, the model must concentrate in its dominant features some aspects of the existing geopolitical concepts and approaches, in particular:

- development of the center with simultaneous support for the periphery given the heterogeneity of the regions (the world-systems approach);

- taking into account the internal contradictions in goal-setting and in the choice of the methods for realizing foreign policy strategies (the concept of glocalism);

- using the inclusivity of norms and political traditions of the globalized world to formulate the Ukrainian version of the implementation of European reforms (the theory of globalism); it is important here to combine the preservation of the authentic features of governance with the acquisition of the characteristics of democracy and 
competitiveness, particularly in the formation of a contemporary political class;

- recognizing Ukraine as a spatial axis of all civilizational transformations (neo-Atlanticism);

- support for democratic reforms in Ukraine as a part of the global process of modernization of the political systems of Western countries (neomondialism).

\section{The Crisis of Geopolitical Choice and Its Risks}

In one way or another, Ukraine has always featured and remains a priority both in conceptual views of geopolitics and on the maps of political interests of the major international players. At the same time, the Ukrainian state itself, since it gained independence in 1991, has pivoted in its foreign policy development and partnerships on multiple occasions, often exacerbating the discrepancy between its political statements, normative decisions and geopolitical orientation. The peculiarities of Ukraine's geographic location have always presented a choice between the West and the East. The choice concerns both politics, economy, and the values ingrained in the national orientation. The principles of geopolitical choice for Ukraine have usually been personified and affected by external influences, which were often not public.

I would be appropriate now not only to determine the factors and characteristics of the geopolitical choice, the circumstances of its crisis nature, but also to define the risks caused by contradictory political actions and decisions. At the same time, it is also worth analyzing the threats that Ukrainian instability poses to the international community, because the war in Donbas and the temporary loss of territories have led to unprecedented sanctions against the Russian Federation, and thus also created ad-hoc international coalitions and blocs. Another important aspect is the impact of global crises on Ukraine.

First of all, we should tackle the question of geopolitical choice, categorizing it. It is a subjective opinion that this concept is identical to the geopolitical orientation, because the latter is mostly defined by the priorities in choosing partners on the international arena, which is de facto done by the political elite. Geopolitical choice is a broader and more complex concept equivalent to the national interest. Thus, it is reasonable to interpret geopolitical choice as the external vector of national selfdetermination, formed with regard for the values and cultural reference 
points of the population, as well as for the priorities of economic development.

Since the moment Ukraine gained independence, its population mostly discussed foreign policy rather than geopolitics, limiting the latter to the directions of developing international connections. The first document that regulated these issues was the Decree of the Verkhovna Rada of Ukraine "On the key directions of Ukraine's foreign policy" of July 2, 1993. ${ }^{17}$ The document, which has expired by now, emphasized the importance of building partnerships with Western states, EU members and NATO; on the other hand, taking into account the particularities of Ukraine's historic development and its specific geopolitical and geoeconomic situation, the document defined the relations between Ukraine and Russia as dominant in terms of bilateral relations with the neighboring states. Further transformations of the foreign policy orientation were made without taking into account the opinion of the population, because the procedure for this was not institutionalized, and were articulated by the state's leaders, particularly by its presidents.

The dominants in the foreign policy preferences of the first two Ukrainian leaders, Leonid Kravchuk and Leonid Kuchma, were equally contradictory. On the one hand, in December 1991, Kravchuk signed the Belovezha Accords that liquidated the USSR and created the Commonwealth of Independent States; at the end of his presidency, in June 1994, he also signed the major Partnership and Co-operation Agreement with the EU, which became the foundation of Ukraine's European integration. On the other hand, the country's main strategic partner in that period was still Russia; Ukraine's collaboration with Russia as an independent state was established in February 1992. President Kuchma also made some dissonant diplomatic decisions which went down in history as the phenomenon of "multi-vector policy." These vectors were formalized in the documents signed by Leonid Kuchma: the Budapest Memorandum on the non-nuclear status of Ukraine and abandoning its nuclear weapons in exchange for sovereignty guarantees by the US, the UK and Russia (1994); the Charter on Special Partnership between Ukraine and NATO (1997); the Treaty on Friendship,

17 Про Основні напрями зовнішньої політики України : Постанова Верховної Ради України» від 02.07.1993 p. № 3360-XII. URL: https://zakon.rada.gov.ua/ laws/show/3360-12. 
Cooperation, and Partnership between Ukraine and the Russian Federation (1997); the Ukraine-NATO Action Plan that defined Ukraine's aspiration for membership in the alliance (2002); the Agreement on the Creation of the Single Economic Space with Russia, Belarus and Kazakhstan (2003).

The defining feature for Ukraine in 1991-2004 was its declared neutrality. First of all, it applied to foreign policy in the context of clear identification of geopolitical partners. However, according to the Ukrainian researcher Iryna Dudko, international relations in the early 1990s were not conducive to the establishment of Ukraine's neutral status - the tendency that requires that the neutrality of any country is established not only at the national but also at the global level did not manifest. ${ }^{18}$ The formal neutrality was also contingent on the subjective factor of Ukraine being identified on the international arena as «a part of Russia». In addition, Ukraine's coherent internal potential and diplomatic toolkit were perceivably insufficient for it to establish itself as an autonomous geopolitical actor. However, the thesis about Ukraine's prospects of becoming an influential state in the world, which was substantianted in the abovementioned parliamentary Decree on the foundations of foreign policy, remained unchanged.

The next Ukrainian president Viktor Yushchenko had an active proWestern state position. This is evident from his many diplomatic visits and negotiations about obtaining the NATO Membership Action Plan, his dialogue with the EU about the visa-free travel regime for Ukrainians, and so on.

The period of 2004-2010, associated with Viktor Yanukovych's presidency, is characterized both by the most considerable domestic crisis for Ukraine and, at the same time, by a consistent transition from implementing foreign orientation policies to formulating a geopolitical choice. Yanukovych signed the Kharkiv Agreements with Russia, prolonging the presence of the Black Sea Fleet of the Russian Federation in Crimea from 2017 until 2042 in exchange for a gas discount (2010). He also initiated the removal of a mention of Ukraine's aspiration to join the NATO from the laws, and added the norm about Ukraine's non-

18 Дудко І. Від декларацій до реалій зовнішньополітичного курсу України: 19912010 рр. Сучасна українська політика. Політики і політологи про неї. 2010. № 21. C. 209-223. URL: http://dspace.nbuv.gov.ua/bitstream/handle/123456789/26808/24Dudko.pdf?sequence $=1$. 
aligned status. ${ }^{19}$ And his refusal to sign the Agreement on association and a free trade zone with the European Union at the Eastern Partnership Summit in November 2013 became the beginning of the end of Yanukovych's presidency and caused the largest civic protest since Ukraine gained independence - the Euromaidan, which transformed into the Revolution of Dignity.

In view of the motives and the articulated demands of Euromaidan participants, this was the event that marked the formulation of a geopolitical choice in Ukraine, based on support for European values, integration of the Ukrainian state to the European Union, development of a Western-style market economy based on open competition. To confront the criticism questioning the objectivity of Euromaidan's representation, we present a number of survey results conducted in 2013-14. In November 2013, the results of IFAK Institute's public opinion survey showed that 58 percent of the surveyed Ukrainians were in favor of Ukraine joining the EU - 6 percent more support than in $2012 .{ }^{20}$ In 2013 , according to the findings of a survey conducted by the SOCIS Center for Sociological and Marketing Research and the Rating Sociology Group, 49.1 percent of the respondents would vote for Ukraine to join the European Union if there was a referendum; 29.6 percent would vote against it, while another 21.3 percent had not decided or were not ready to participate in such a referendum. Among those who have decided, the share of EU supporters is 62.4 percent. $^{21}$ The dynamics of public opinion shifts was demonstrated by the results of a joint study by Ilko Kucheriv Democratic Initiatives Foundation and the Razumkov Center. The percentage of supporters of Ukraine's European integration orientation grew from 49.1 percent in October 2011 to 50.5 percent in May 2014, with the highest support in the West of Ukraine (almost 88 percent) and the lowest support in the South (28 percent $)^{22}$.

19 Червоненко В. П'ять президентів України: чим вони запам'ятались. URL: https://www.bbc.com/ukrainian/features-48188256.

${ }^{20}$ DW-Trend: більшість українців - за вступ до EC. URL: https://www.dw.com/uk/dw-trend-більшість-українців-за-вступ-до-єс/a-17230854.

${ }^{21}$ Суспільно-політична ситуація в Україні: грудень 2013. URL: http://ratinggroup.ua/research/ukraine/obschestvennopoliticheskaya_situaciya_v_ukraine_dekabr_2013.html.

${ }_{22}$ Ставлення громадян до зовнішньополітичного вектору України: регіональний poзpi3. URL: https://dif.org.ua/article/stavlennya-gromadyan-do-zovnishnopolitichnogovektoru-ukraini-regionalniy-rozriz. 
The purely pro-European course of the newly elected president Petro Poroshenko also took shape as an extension of the social re-orientation. These geopolitical aspirations also determined such decisions as signing the Association Agreement with the EU, fulfilling the requirements for the visa-free regime for Ukraine, the termination of the Treaty on Friendship, Cooperation, and Partnership with Russia, and the formalization of the country's NATO and EU membership aspirations in the Constitution of Ukraine.

Going back to the substance of the thesis on geopolitical choice that was articulated above, we can state that it has taken the form of a meaningful aspiration in Ukraine in the period since 2014; the geopolitical choice in favor of the Western model of state-making became the foundation for the foreign vector of national self-determination and was supported by the choice of values and cultural reference points among the population. However, already in 2019, when Volodymyr Zelensky won the presidential election, Ukraine started getting contradictory messages from the state's leadership - about the need to negotiate with the Russian Federation on ending the war in Donbas, about a referendum on the questions of dialogue between Ukraine and Russia and on potential membership in the EU and NATO. These signals were naturally perceived as ambiguous by Western states, particularly because of the unclear prospects of the global reforms which became a kind of "entry ticket" to the united Europe for Ukraine. To sum up, we emphasize that the defining role under the conditions of Ukraine's current form of governance will be played by the results of the parliamentary election in late July 2019 and by the new configuration of political forces in the 9th Verkhovna Rada.

Thus, the political process in Ukraine, which started in 1991, shaped two tendencies - a normative and an empirical one - which contradicted each other for a long time and have developed shared characteristics only since 2014. The political-civilizational shift was caused by the formation of public civic demand for qualitatively new state policies, particularly foreign policies. Shifts happened in the public consciousness, too, displacing the tradition of the previous orientation's succession and conservation.

Recognizing the crisis markers and risks in the geopolitical vector of contemporary Ukraine, we will emphasize the following ones:

- In the situation of a democratic transformation of political institutions, high-quality modernization of the foreign policy 
orientation can be assured by the guaranteed implementation of reforms - their success directly affects the country's credibility in the eyes of the global community. Changes in the political elite often entail rejection of previous innovations, even if they were approved on the international arena.

- According to Article 106 of the Ukrainian Constitution, the president represents the state in international relations, supervises the foreign political activities of the state, holds negotiations and signs Ukraine's international agreements. ${ }^{23}$ Therefore, there is no guarantee here that the already selected and initiated foreign policy path will be effectively prolonged by the newly elected head of the state.

- The long-term absence of a fixed foreign policy vector of the country's development, the constant risk of being affected by more powerful international players, including in the form of pressure by force, have led to an unstable course of foreign policy and an urgent need for a quality upgrade in this sphere from the ideological and institutional perspective and in terms of personnel.

- The crisis of geopolitical choice also entails risks of adversely affecting the society and the economy. Shifting foreign policy priorities motivate the activation of migration processes, stall export-oriented manufacturing, destroy cross-border connections, can lead to ethnic conflicts, etc.

- Ukraine is still burdened by economic obligations to international financial institutions. Its geopolitical reorientation can decrease trust in the Ukrainian state, complicate further cooperation or even make it impossible. 2019 and 2020 will be the most challenging years for Ukraine in this context, because these are the years when, in addition to building new foundations for state policies, Ukraine has to pay back peak sums of its foreign debt.

Another sign of the crisis of geopolitical choice is the fragmented and selective implementation of the adopted laws which have determined the country's foreign policy priorities and regulated the means of their realization since 1991. The issue of European integration was normatively formalized for state purposes back in the 1990s; however, any actual shifts were implemented only in twenty years.

23 Конституція України : офіц. текст. URL: https://zakon.rada.gov.ua/laws/ show/254\%D0\%BA/96-\%D0\%B2\%D1\%80. 
In addition to the internal dialectics of geopolitical choice, Ukraine is also affected by the state of the global community as a whole, of its geostrategic imperatives, development trends and the formulated markers of instability, which influence Ukraine's place in the political world in one way or another.

The issues that are currently the focus of attention of the global community are wars or threats of war, economic stability, environmental security and so on. In general, control over the totality of these phenomena represents the contemporary understanding of the concept of "world order." The degree of concern and involvement of particular countries in resolving these issues is determined by the country's vulnerability to various risks. For example, some actions that make sense today include economic support for a weaker neighbor in order to avoid mass migration (the implementation of various grant projects for Ukraine by the neighboring EU member states), activation of military exercises if military operations are taking place in a neighboring country (the situation in Serbia, which brought its troops to full alert because of the operation in Kosovska Mitrovica), or organization of an emergency vaccination campaign because of a disease outbreak in a region across the border (the situation with the measles epidemic in the neighboring Romania and Ukraine). As we can see, in the past decade, Ukraine has played the role of both the active and the passive participant of such actions.

The beginning of 2019 was marked with the inclusion of instability in Ukraine in the top ten biggest global risks this year, according to the Eurasia Group consultancy firm. ${ }^{24}$ In general, Ukraine, with its troubles, took the ninth place out of ten selected by the experts. The key risks for the world this year, according to Eurasia Group, are:

- «bad seeds»: the world's decision-makers are so consumed with addressing the daily crises that arise that they're allowing a broad array of future risks to germinate;

- US-China relationship;

- cyberwar;

- European populism;

- the US domestic policy;

${ }^{24}$ Нестабільність в Україні - в десятці найбільших ризиків світу 2019 року Eurasia Group. URL: https://ua.krymr.com/a/nestabilnist-v-ukraini-u-top-ryzykiv-svitu-u2019/29697766.html. 
- «innovation winter»: analysts predict that the amount of financial and human capital in high tech will be reducing;

- «coalition of the unwilling»: the US president Donald Trump is sceptical of Washington's role in protecting the global legal order, and a number of world leaders support him in this;

- political risks in Mexico: the country's new president, Andres Obrador, actively pursues a policy of increasing the role of the state in the political cycle;

- the Ukrainian crisis;

- Nigeria is facing its most fiercely contested election since the country's transition to democracy in 1999.

Another danger "without a number," according to the experts, is the Brexit, the UK's expected exit from the European Union. Actually, the implications of Brexit as the event of the year in the global politics can also affect Ukraine. As a part of the EU, the UK has usually been on the side of those who advocate for the Ukrainian question in the context of preserving sovereignty and who support the European integration progress of Ukraine. Therefore, if the UK leaves the European Union in October 2019, Ukraine will lose an influential partner in the West. However, the country will probably remain a partner of the Ukrainian reforms, which have been highly evaluated by the British leadership. Further risks in the relations between Ukraine and the UK are associated with the figure of the country's future Prime Minister. Since Theresa May announced her resignation in May 2019, more than ten politicians have already expressed their willingness to run for the top government office; each of them has their own vision of the situation in Ukraine.

While the world's priorities before were about promoting economic interests, stability and development, now these priorities are competing with military and political affairs. For example, according to Die Welt's leading writer Holger Zschaepitz, the trade war, Brexit, the disorganized EU are the main geopolitical risks of the present, while the state of the economy is rather satisfactory. ${ }^{25}$

The phenomena that have been collectively recognized as the "Ukrainian crisis" include, according to Western analysts, the Russian military and political influence on the internal transformations in Ukraine,

25 Шара A. Die Welt: геополітичний прогноз на 2019, нова холодна війна між Росією та США. URL: https://tyzhden.ua/World/225422. 
the lobbying of the interests of pro-Russian politicians during the election campaign process, a religious confrontation. This state of affairs proves that domestic conflict and instability can be, and in the case of Ukraine are, a real geopolitical risk.

\section{CONCLUSIONS}

The analysis of geopolitical assessments of Ukraine from the perspective of various concepts allows us to state that:

- Ukraine lies not only on the spatial boundary between the West and the East, but also on the crossroads of the traditions of individualism and collectivism.

- Regardless of how we define the leading states in the global politics, Ukraine has been and remains a strategically important geopolitical unit for them, which is proven by the permanent place of the "Ukrainian issue" on the agenda of the most important meetings and events of major international organizations and unions (the EU, the UN, NATO, etc.).

- The trends and risks of the current situation in the region determine the importance of not just the West-East axis, but also the North-South axis. In particular, the important aspects here are the strategic support from the South (e.g. Turkey), the nominal neutrality of the near North (Belarus), the partnership of the further North (the Baltic countries).

- The implications of Ukraine's location on important transit routes, the country's powerful natural resources potential, and its shared borders with many countries, the majority of which have already successfully completed the European integration path, are, on the one hand, the availability of many options for its foreign policy, and on the other hand, the difficulty with implementing geopolitical strategies in the direction of European integration because of the country's borderline location.

In addition to including Ukraine in the modern geopolitical theories, when our study started to rely on the factors of civilizational belonging and the state's political choice rather than on the geographic component, Ukraine itself became a prominent and significant element of the contemporary geopolitical space. The "actor" category has been avoided on purpose, since we often meant passive participation and the factor of dependence. First, this is about Ukraine's sensitivity and vulnerability to global crisis phenomena. Second, Ukraine is itself experiencing a deep crisis of geopolitical choice, which has only exacerbated with the change 
of government in spring 2019. Third, instability in Ukraine in recent years has been recognized as one of the ten urgent risks for the world.

As for the risks caused by the lack of stable geopolitical choice, they are the incoherency and contradictory nature of the country's foreign policy orientation, and the difficulty of forming a positive international image for the country because of its frequently shifting policy priorities after each electoral period. Other risks still include the constant threat of foreign pressure, particularly by military means, that affects the implementation of domestic reforms. In addition, an urgent issue for Ukraine is the probability of complications with fulfilling its financial obligations. At the same time, the fact remains that the leading geopolitical actors are interested in preserving their capacity to affect Ukraine as the axis where the interests of the West and the East collide, as an embodiment of civilizational development, and as one of the most optimal transit routes of Europe and Asia.

\section{SUMMARY}

The article analyses the role and place of Ukraine in contemporary geopolitical concepts, determines the trends and priorities for Ukraine in the context of global theories (globalism, glocalism, world-systems approach, contemporary Anglo-American school of geopolitics), contemporary forms of Atlanticism and mondialism, and the polar opposite of Eurasianism. Based on the conducted analysis, it is proposed that today Ukraine is one of the geopolitical centers which, due to a number of internal factors, affects the diplomatic prioritysetting among the leading political actors on the international arena. The article proposes a geopolitical model that is based on the characteristics of existing models and takes into account the intrinsic potential, needs and interests of Ukraine. It makes a distinction between the concepts of "foreign policy orientation" and "geopolitical choice," where the latter is defined as the external vector of national self-determination formed with regard for the values and cultural reference points of the population, as well as for the priorities of economic development. Given the lack of a stable strategy of foreign policy implementation and the contradictory nature of the declared and the implemented geopolitical goals, the article concludes that there is a crisis of geopolitical choice in Ukraine. It entails the risks of foreign 
pressure, loss of international credibility, financial insolvency in the context of fulfilling the country's debt obligations, etc.

\section{REFERENCES}

1. Huntington S. The Clash of Civilizations. Foreign Affairs. Touchstone, 1993. URL: http://online.sfsu.edu/mroozbeh/CLASS/h-607pdfs/S.Huntington-Clash.pdf.

2. Huntington S. The Clash of Civilizations and the Remaking of World Order. Harvard University Printed, 1996. URL: http://www.academia.edu/4610592/Samuel_P_Huntington_The_Clash_of _Civilizations_and_the_Remaking_of_World_Order_1996.

3. McKew Molly K., Maniati Gregory A. Putin's global ambitions could destabilize Europe. The Washington Post. March 18, 2014. URL: https://www.washingtonpost.com/opinions/putins-global-ambitions-coulddestabilize-europe/2014/03/18/69abb2a2-aec5-11e3-9627-c65021d6d572_ story.html?utm_term $=.84 \mathrm{f} 30 \mathrm{a} 2 \mathrm{~d} 8 \mathrm{c} 78$

4. Huntington S. The Clash of Civilizations. Foreign Affairs. Touchstone, 1993. URL: http://online.sfsu.edu/mroozbeh/CLASS/h-607pdfs/S.Huntington-Clash.pdf.

5. Wolfowitz P. Defense Planning: Guidance. URL: https://www.archives.gov/files/declassification/iscap/pdf/2008-003docs1-12.pdf.

6. Бжезінський 3. Велика шахівниця. Львів-Івано-Франківськ : Лілея-НВ, 2000. С. 9.

7. Brzezinski Z. Strategic Vision: America and the Crisis of Global Power. New York, 2012. URL: https://orientalreview.org/wp-content/ uploads/2012/12/Brzezinski-Zbigniew.-Strategic-Vision-America-and-theCrisis-of-Global-Power.pdf.

8. Fukuyama F. The End of History? The National Interest. 1989. № 16. P. 5.

9. Attali J. Lignes d'horizon. Paris, 1990. 216 p.

10. Френсіс Фукуяма: Україна грає величезну роль в Європі у всіх сенсах - Atlantic Council. URL: https://zik.ua/news/2019/05/ 14/frensis_fukuyama_ukraina_graie_velycheznu_rol_v_yevropi_u_vsih_ sensah_1570941.

11. Attali J. Ukraine: sont ils tous devenus fous? URL: http://marcrousset.over-blog.com/article-ukraine-sont-ils-tous-devenusfous-selon-jacques-attali-123114753.html. 
12. Дугин А. Началась Великая Война Континентов. Пражский Телеграф. 9 апреля 2014 г. URL: http://ptel.cz/2014/04/aleksandrdugin-nachalas-velikaya-vojna-kontinentov.

13. Robertson R. Interpreting Globality. World Realities and International Studies. PA : Pennsylvania Council on International Education, 1983. P. 7-20.

14. Robertson R. Globalization: Social Theory and Global Culture. Journal of World History. 1994. № 5/1. P. 159.

15. Robertson R. Beyond the discourse of globalization. Glocalism: journal of culture, politics and innovation. 2015. № 1. P. 12.

16. Wallerstein I. The Geopolitics of Ukraine's Schism. URL: https://www.iwallerstein.com/geopolitics-ukraines-schism.

17. Про Основні напрями зовнішньої політики України : Постанова Верховної Ради України» від 02.07.1993 р. № 3360-XII. URL: https://zakon.rada.gov.ua/laws/show/3360-12.

18. Дудко I. Від декларацій до реалій зовнішньополітичного курсу України: 1991-2010 pp. Сучасна українська політика. Політики і політологи про неї. 2010. № 21. С. 209-223. URL: http://dspace.nbuv.gov.ua/bitstream/handle/123456789/26808/24Dudko.pdf?sequence $=1$.

19. Червоненко В. П'ять президентів України: чим вони запам'ятались. URL: https://www.bbc.com/ukrainian/features-48188256.

20. DW-Trend: більшість українців - за вступ до EC. URL: https://www.dw.com/uk/dw-trend-більшість-українців-за-вступ-до-єс/ a-17230854.

21. Суспільно-політична ситуація в Україні: грудень 2013. URL: http://ratinggroup.ua/research/ukraine/obschestvenno-politicheskaya_situa ciya_v_ukraine_dekabr_2013.html.

22. Ставлення громадян до зовнішньополітичного вектору України: регіональний розріз. URL: https://dif.org.ua/article/ stavlennya-gromadyan-do-zovnishnopolitichnogo-vektoru-ukrainiregionalniy-rozriz.

23. Конституція України : офіц. текст. URL: https://zakon.rada.gov.ua/laws/show/254к/96-вр.

24. Нестабільність в Україні - в десятці найбільших ризиків світу 2019 року - Eurasia Group. URL: https://ua.krymr.com/a/ nestabilnist-v-ukraini-u-top-ryzykiv-svitu-u-2019/29697766.html. 
25. Шара A. Die Welt: геополітичний прогноз на 2019, нова холодна війна між Росією та CША. URL: https://tyzhden.ua/ World/225422.

Information about the author: Shchedrova H. P. Doctor of Political Sciences, Professor, Head of the Department of Political Science and International Relations, Alfred Nobel University 18, Sicheslavska Naberezhna str., Dnipro, 49000, Ukraine 


\section{“LEFT-RIGHT" PARTY-IDEOLOGICAL DELINEATION AS A PRINCIPAL MEAN OF STRUCTURING OF THE POLITICAL LANDSCAPE}

\section{Shypunov H. V., Prokop M.}

\section{INTRODUCTION}

Having emerged (mostly accidentally) in the late XVIII century in France, the concept of "left-right" party-ideological delineation nowadays has become one of the most widespread and universal methods for structuring of the political landscape, which is actively used both in the political science research and in the journalistic discourse. Paying homage to the important role that this concept plays in the modern political science, we may also derive two principal functions, which this concept plays in the real social and political life: on the collective life, it is beneficial for social orientation and simplifies political communication. Thus, it functions as a symbolic system of coordinates, which enables parties to perform their positioning and stand out among another political forces, having tied own political position with the place in the said system. On the individual level, this concept helps people to make a reasoned political choice based thereon ${ }^{1}$.

Introduction and definitive establishment of the "left-right" semantics in the political science discourse, which, however, is characterised by the instability of the principal terms (they are constantly changing, attracting new features and content depending on one or another social and political context, or even political traditions, which are ruling in a certain region ${ }^{2}$ ), gave push to a continued scientific discussion regarding the specifics of conceptualisation of the mentioned delineation and its research potential ${ }^{3}$. We should also stress here that Western political science is represented by a whole complex

${ }^{1}$ Knutsen O. Value Orientations, Political Conflicts and Left-Right Identification: A Comparative Study. European Journal of Political Research. 1995. Vol. 28, Issue 1. P. 63.

2 Jahn D. What is Left and Right in Comparative Politics? A Response to Simon Franzmann. Party Politics. 2014. Vol. 20, Issue 2. P. 297-298.

${ }^{3}$ Huber J., Inglehart R. Expert Interpretations of Party Space and Party Locations in 42 Societies. Party Politics. 1995. Vol. 1, Issue 1. P. 74. 
of the fundamental research of the specifics of "left-right" delineation. This is evidenced by the works of, among others, N. Bobbio, D. Jahn, J. Huber, R. Inglehart, H. Klingemann, H. Kitschelt, M. McDonald, C. de Vries. At the same time, we can make a conclusion that this issue is underresearched within the framework of Ukrainian political science. Certain separate aspects of this issues are analysed in the works of Y. Shveda, A. Romanyuk, A. Kolodiy, M. Karmazina, A. Glivinskyi, M. Prymush.

The topicality of this problem and its underdevelopment within the framework of our native political science formulates principal goals of our research: firstly, a methodological clarification of the substantial characteristic of the notions "left", "right" and "center"; secondly, determination of the criteria of delineation based thereon, which, in its turn, would allow us to clearly identify left, right and centrist parties; thirdly, definition and research of the specifics of the "left-right" partyideological delineation, which have developed in the political landscape of the post-communist states in the Central and Eastern Europe in the context of their double transit - to the democracy and market economy.

\section{Left and Right: Principal Approaches to the Conceptualisation in the Political Science}

As of today, there are two principal approaches in the political science to the definition of values and issues that form the content consistency of the left and right dimensions of the political landscape: deductive (a priori) and inductive (a posteriori).

The notion of the first one lies in the deriving of the content characteristics of the left and right in the political theory, namely, from the classical works of the philosophical and political thinking and defining researches of the representatives of political science. The adherents of the second approach formulate the criteria for left and right based on the empirical observations: they perform preliminary measurements of the party and social positions out of the several issues in the society used as indicators for creating specific constructions, which the researcher later interprets. Therefore, the substantial definitions of the left and right in this aspect are the result of their analytical interpretation. In other words, the basis of this approach is the empirical definition of 
those problematic issues, which are common for certain parties. This allows to unite them in a joint left or right party family ${ }^{4}$.

Defining the indicators for the left, right and centrist parties, we would be using the positions of the deductive approach. Let us refer to the theory and classics of the political science. In 1957 A. Downs was one of the first to apply space analogy of the "left-right" positioning of the parties and ideologies (in the form of a linear scale). In his words, the principal question, which allows to make such a delineation is a measure of state involvement into the economy: left ending of the scale represents a total state control, while right stands for a completely free market ${ }^{5}$.

Other representatives of the American political science S. Lipset, P. Lazarsfeld, A. Barton and J. Linz, while researching the electoral behaviour of voters, were considering the following criteria of the delineation: the left ones are those, who stand for social changes in the direction of the larger equality - political, economic and social; right ones are those, who support traditional, more or less hierarchical order, as well as resent those changes leading to a larger equality ${ }^{6}$.

Transition of the leading industrial states to a post-industrial stage of development, which was remarkable, namely, due to the change of value priorities of those societies (the forefront was taken by the new, postmaterial problems connected with the quality of life and personal selfidentification $^{7}$ ), placed a question of the adequacy of the "left-right" dichotomy within the new social and political conditions. In this context, R. Inglehart and H. Klingemann, emphasizing, on one hand, that the crucial problems, which in complex determine the "left-right" dimension, and on the other hand, "identified a constant and omnidirectional issue", which allows to identify left and right. They were of the opinion that despite of the significance of the economic equality has somewhat lowered, the lefts have remained typical defenders of the changes, which were aimed at achievement of a larger equality, specifically emphasizing on the equal involvement of everyone in a political and social life.

${ }^{4}$ Jahn D. What is Left and Right in Comparative Politics? A Response to Simon Franzmann. Party Politics. 2014. Vol. 20, Issue 2. P. 297-298.

${ }^{5}$ Downs A. An Economic Theory of Political Action in a Democracy. The Journal of Political Economy. 1957. Vol. 65, Issue 2. P. 141-142.

${ }^{6}$ Weber W. Behind Left and Right. The Meaning of Left-Right Orientation in Europe URL: http://www.tdx.cat/bitstream/handle/10803/107624/tww.pdf? sequence=1. P 97. (дата звернення: 21.05.2018).

${ }^{7}$ Инглхарт Р. Постмодерн: меняющиеся ценности и изменяющиеся общества. Полис. 1997. № 4. С. 6-32. 
Whereas the defining feature of the right is a hierarchical order. Therefore, the essential dilemma of the politics is an opposition between the equality and traditional (hierarchical) order ${ }^{8}$.

It is a question of equality, quoting the Italian thinker N. Bobbio, that is a constant end value defining the "left-right" delineation". By naming the lefts as egalitarian and the rights as anti-egalitarian, he emphasizes that while the first ones do not deny the fact that people are as equal as they are unequal, they also prefer that what makes them equal, rather than unequal. In their turn, the latter, deriving from the same situation, within the same conditions prefer that what makes people unequal rather than equal. The contrast between the end choices, in the opinion of N. Bobbio, is the best to mark the lefts and the rights.

In practice, this delineation transforms into the difference in evaluation of what is relevant for justification or denial of the discrimination. Therefore, we mean the definition of a criterion (or criteria) of discrimination. This depends on the approach to the level of importance of certain forms of differences, which ones (anti-egalitarian) consider a sufficient ground for unequal treatment, and others (egalitarian) don't: egalitarian are striving to level the differences (meaning to lower the amount of grounds for discrimination), whereas the anti-egalitarians are inclined to overestimate their importance (which means to increase the grounds for discrimination $)^{10}$.

The conceptual approach of $\mathrm{N}$. Bobbio has gained a widespread popularity in the modern political science. Aside from the existence of certain sceptic views on his empirical adequacy in the context of determination of substantial differences between left and right, such approach become a foundation of the many further research attempts of this opposition ${ }^{11}$. Namely, German researcher D. Jahn based on this approach developed an original concept of the "left-right" delineation.

${ }^{8}$ Inglehart R., Klingemann H.-D. Party Identification, Ideological Preference and the Left-Right Dimension among Western Mass Publics. Party Identification and Beyond: Representations of Voting and Party Competition / I. Budge, I. Crewe, D. J. Farlie (eds.). Colchester: ECPR Press, 2010. P. 258-259.

${ }^{9}$ Bobbio N. Left and Right: The Significance of a Political Distinction / translated and introduced by A. Cameron. Chicago: The University of Chicago Press, 1997. P. 58-59.

${ }^{10}$ Ibid. P. 66-70.

${ }^{11}$ Rosas J. C., Ferreira A. R. Left and Right: Critical Junctures. Left and Right: The Great Dichotomy Revisited / J. C. Rosas, A. R. Ferreira (eds.). Newcastle upon Tyne: Cambridge Scholars Publishing, 2013. P. 6-9. 
In our view, we should first of all pay attention to the following methodological principles of such approach. Firstly, to resolve an internally disputable problem of the stability and changeability of the substantial definitions of the left and right we need to determine pivotal and pivot-related ancillary characteristics of the left and right. This is because such pivotal components are stable and valid in any given time and context, which allows to make clear delineation at all times. Ancillary ones are changing as the time goes by and in specific contexts, which allows to affix the peculiarities of the "left-right" division in different time periods and its national specifics (dependency on a historical and political context of the country or region).

Secondly, while determining the pivotal and ancillary characteristics we need to clearly define the level of their "leftness" and "rightness". In other words, we need to range them from the strongest (those who most definitely influence the belonging to either "left" or "right") to the weakest. Otherwise, a party, which formulates several moderate "left" statements and one mighty "right" declaration, may be classified as left, while having significant grounds to assume the contrary ${ }^{12}$.

Thirdly, the right are not a homogeneous force and are different in their approach to inequality. While agreeing with $\mathrm{N}$. Bobbio that the principal delineation border between the left and right is their different ontological positions in the evaluation of the ideal of equality, D. Jahn simultaneously insists on the necessity of differentiation of the right: one part of the right considers social inequality artificial, while other part - natural.

Such delimitation, on one hand, between the left and right, and on the other hand - between the right themselves finds its description in the three big classic ideologies: socialism, liberalism and conservatism. While the left (socialists) concentrate on the questions of equality, the right (liberals and conservatives) substantiate the objectivity of the existence of inequality differently: conservatism considers it as given by the very nature, while liberalism stems from the fact that the place of the human in the society is determined solely by the human activity ${ }^{13}$.

This approach, which makes a clarification of the characteristics of "left-right" delineation possible, has advantages in both theoretical and

12 Jahn D. Conceptualizing Left and Right in Comparative Politics: Towards a Deductive Approach. Party Politics. 2011. Vol. 17, Issue 6. P. 749-750.

${ }^{13}$ Ibid. P. 751. 
empirical dimensions. This is because it allows to adequately comprehend its variability, in particular, to include to the conceptual description of the left and right new questions of the post-material character. Here we derive from the methodological position of the coexistence of the traditional and new definitions of the left and right, which do not displace one another from the political discourse, but rather become more or less significant in the context of a certain social, political and economic situation $^{14}$. This creates grounds to reassessment of the traditional views on the "left-right" delimitation of the political landscape in the format of a one-dimensional linear division. We are talking about the necessity of considering material and post-material questions in determination of the substantial characteristics of left and right, which transform it into a twodimensional, within which the positioning of the political forces as left and right takes place: under one conditions with the emphasis on the economic matters, under other conditions - on the socio-cultural matters.

Therefore, considering primarily methodological approaches of $\mathrm{N}$. Bobbio and D. Jahn, stemming from the defining meaning of the principle of equality/inequality in the context of delineation of the left and right political parties, we can define the following indicators, which would divide into two clusters.

\section{Left political parties.}

First cluster of indicators - "traditional" (material). The principal thesis of this cluster is the following: the main source of the social, economic and political inequality in the society is the capitalist system, which is founded on free market and private property. Therefore, the strive for overcoming the inequality predetermines the necessity of change of the existing system of relationship and introduction of a new one, which would be based on different grounds.

The substantial characteristics of the new system evolve depending on the level of the "leftness" of claims, which is determined by the ideological positions of political parties. We shall place such characteristics with the respective claims in the descending order of the aforementioned level: 1) communal property over the means of

${ }^{14}$ De Vries C. E., Hakhverdian A., Lancee B. The Dynamics of Voters' Left/Right Identification: The Role of Economic and Cultural Attitudes. Political Science Research and Methods. 2013. Vol. 1, Issue 2. P. 228. 
production (requests of total nationalisation and liquidation of private property); 2) all-around state control and regulation of the social and economic spheres (categorical denial of the principles of free market, requests for establishment of planned principles of organization and management of the economy, adherence to the principle of inclusiveness in the provision of social goods and services); 3) mixed property regime (ability of effective coexistence of private and state property, partial nationalisation); 4) partial state control and market regulation (social market economy, requests of complete realisation of the welfare state, adherence to the principle of wide selectiveness in provision of the social goods and services (to all social groups in need, namely, those, whose material conditions makes it impossible to purchase such goods and services)).

The abovementioned claims, which actually means the change of the capitalist system, may be realised through means of revolution or reform. The revolutionary (radical) way provides for the following: use of violent methods of political struggle and realisation of the doctrinal notions. This means, in particular, the denial of the fundamental democratic principles of political competition, as well as readiness to (necessity of) breaking individual, political and civil rights and freedoms for achieving ideological goals. On the contrary, the reform (considerate way) defines the respect for fundamental civil right and freedoms, recognition and use of the democratic mechanisms as those solely possible instruments of political struggle, which draws a wide field of opportunities for an effective political dialogue with moderate ideological opponents.

Second cluster - "new" (post-material). Key thesis: principles, which define the substantial parameters of functioning of the modern developed industrial society determine social inequality, and, thus, must be dropped and changed to those, which would create a new social reality with the maximum levelling of the inequality.

We should note that here, the principle of equality not only strives to stand out in the economic dimension, but rather to acquire the quality of total emancipation of a human, liberation of human from all traditional form of addictions and limitations, which are brought onto human by the modern market society, obtaining of equal rights in all spheres of the social being. Therefore, we may observe here an increase of the space of necessary emancipation, struggle for which, as of today, got rid of solely economic (material) and social or class character. 
This is evident in the strive for: 1) maximum expansion of the space of individual autonomy and equal rights of human (individual and legal emancipation - defending the right to choose individual lifestyle and struggle for reduction of the criteria for discrimination: gender, sexual, race and national liberation); 2) procurement of the widest and equal participation of citizens in the political process possible (political emancipation - struggle for liberation of the individual from under control of the hierarchical, bureaucratic and oligarchic political and powerful structures of the welfare state; contradistinction of participatory model of democracy to egalitarian model; consequently, denial of the principle of "powerful state" and requests for organisation of state and political life on the foundations of autonomy, solidarity and decentralised networks); 3) levelling of the inacceptable risks of modernisation, which bear threat to human life and the surrounding environment (ecological emancipation - requests for setting up of equal relationship between human and nature, liberation of human from the dangers, which the irresponsible (consumerism) approach to the surrounding environment and militarism pose to him); 4) guaranteeing of the unimpeded access of all citizens to intellectual resources (intellectual emancipation - the requests of lifting all restrictions on the way to obtain the information and knowledge necessary for a person).

We should also pay attention to additional indicators that are directly related to the principal ones: 1) critique of the ideological union between capital and workers, which was concluded in developed industrial societies, resulting in the latter becoming the foundation of the bourgeois lifestyle and become "sublimated slaves of the developed industrial civilisation" "15) 2) critique of the traditional left political parties, which have de facto stopped being left due to: a) compromises with the ideological opponents, joint participation in government and integration into the existent political system; b) retreat from the doctrinal foundations of activity and, as a consequence, loss of historic ideological mission; c) excessive hierarchizing, bureaucratisation and centralisation of the party structures; 3) critique of the establishment for usurpation of the people's sovereignty and de facto monopolisation of the process of approval of political and state decisions.

${ }^{15}$ Маркузе Г. Одномерный человек / пер. с англ. А. Юдина. Москва: REFL-book, 1994. C. $42-43$. 
The issue of attitudes to revolution and violence as methods of political struggle and the realization of ideological settings requires separate clarification. We need to understand here clearly that the idea of revolution in the modern developed society has undergone a deep delegitimising - it is no longer seen as an effective method of performing social, economic and political changes, while at the same time use of violence as a mean of political struggle is seen as a sign of extremism and terrorism. Given this background, the practical reference to those means has become a destiny of the marginalised or semi-legal ultra-left political organisations and social movements.

Therefore, appealing to the idea of revolution in the modern environment is, for many ultra-left representatives, rather a theoretical tribute to the ideological tradition than a direct guidance for practical political action. Under these circumstances, the reassessment of this idea is performed in the spirit of the concept of "molecular aggression into the cultural core" by A. Gramsci ${ }^{16}$. Hence, the revolutionary strategy is considered not within the context of the violent dismantling of the existing system as a result of class opposition, but as a scrupulous fight for change of the opinions and feelings in the consciousness of each individual human being.

Right political parties.

First cluster of indicators - "traditional" (material).

Right (liberals). Main thesis: the free market creates a space of equal opportunities and chances for individuals to realize their abilities and talents. Social inequality is artificial. This means that the place of naturally equal people in their rights and freedoms in the social hierarchy is determined solely by the results of their activities: the more you work, the more you get. The ability to realize one's potential is correlated with the protection of individual freedoms, which primarily implies liberation from state interference.

These provisions are disclosed and specified in the following indicators: 1) free market economy and private property as a basis for organization of social life (priority of private initiative; requirements to minimize state intervention in the social and economic spheres;

${ }^{16}$ Грамши А. Тюремные тетради: в 3-х ч. Ч. 1. / пер. с итал. Москва: Политиздат, 1991. C. 65. 
maximum limitation of its controlling and regulating functions; interpretation of social functions of state as a violation of citizens' freedoms and shift of responsibility for his own destiny to the level of society); 2) restriction of the welfare state (the need to observe the principle of narrow selectivity in providing social benefits and services in order to minimize public expenditures on this: assistance only to those categories of population who have objective problems with the possibility of realizing their chances (e.g., orphans, disabled, single families, etc.)); 3 ) effective combination of the principles of the free market and the welfare state (substantiation of the possibility of state intervention in the economic life and a broad interpretation of its social functions in order to overcome unemployment and poverty in society, more equitable implementation of the principle of "equality of chances").

Right (conservatives). Main thesis: social inequality is natural. The place of the individual in the hierarchical structure, which is inherent in the organic society, is determined by traditions and natural social order.

It should be noted here that from the economic standpoint conservatives, as well as liberals, are consistent supporters of the free market and private property. However, they consider their importance from a somewhat specific perspective: as institutions that define social discipline, promote stability in society, and help to increase the level of independence and self-realization of the individual.

The views on the role of the state are also specific: in social and economic terms, approaches within different areas of conservatism vary from categorical requirements of the maximum limitation of state intervention in economic life and reduction of social programs to the recognition of the need for state participation in economic processes to ensure a certain standard of living for all citizens, a combination of moderate conservatism and social liberalism (which is typical for Christian democratic parties). At the same time, it should be noted that in the social and political dimension, conservatives are apologists for strong state power (sometimes even authoritarian), since it is this state that provides the organization and order in society, as well as guarantees the observance of legal norms and traditional values.

The ideological priority of tradition and order inherent in conservatives is revealed and specified in the following indicators: 1) tradition and morality as the fundamental basis of society and its effective development (the requirements of the prohibition of such 
individual lifestyles and types of behavior that do not fit into the conventional, generally accepted moral framework (i.e., evaluated as immoral); support and promotion of traditional family unit as a fundamental value; recognition of the special role of religion and religious institutions in public life); 2) ethnocentrism, cultivation of the national way of life (the people as the highest value; proclamation of traditional national values as the basis of social development; formulation and support on this basis of the national idea; calls for patriotism and nationalism); 3) social harmony (the need to ensure and maintain harmony in a socially heterogeneous society as a means of compliance with the natural, i.e., predetermined, social order).

The degree of radicalization of these demands is directly proportional to the degree of denial of the fundamental liberal and democratic principles of organization of social and political life. Above all, it concerns the attitude of the minorities of any and all kinds and methods of combating their ideological opponents, which, in fact, determines the affiliation of such parties to the category of the ultra-right ones.

Second cluster - "new" (post-material). Turning to the identification of the second group of indicators, we should note that they will determine the affiliation of political power, above all, to the new farright parties whose ideological inspiration was the metapolitical intellectual movement of the "New Right".

Contradicting themselves with the value foundations of the "new left", the "new right" brought into the political discourse post-material issues of the right substance. According to the fair comment of S. Flanagan, the "new left" pushed economic issues aside from the political agenda, but at the same time they provoked a whole set of "new right" issues ${ }^{17}$.

The main thesis within this block can be formulated as follows: the formation of a new, liberal social and cultural reality of post-industrial society, which would be based on the principles of emancipation and egalitarianism accompanied by a departure from the tradition and moral values, and also lead to the decline of the natural social order, based on social inequality. All this leads to the destruction of the institution of traditional family, moral and spiritual degradation of a human, crisis of

${ }^{17}$ Inglehart R., Flanagan S. C. Value Change in Industrial Societies. The American Political Science Review. 1987. Vol. 81, Issue 4. P. 1308. 
national and cultural identity, erosion of state sovereignty, weakening of the national state, deep political and economic crises. The solution for this condition is to implement a policy aimed at restoring the social and cultural status quo, returning to the tradition, morality and natural social harmony, which in its totality is embodied in the idea of building a culturally and ethnically homogeneous national state.

This strategy is disclosed and specified in the following provisions: 1) nationalism and anti-immigrant policy (upholding the principle of privileges (based on ethnic origin) in the matters of citizenship and political rights; requests for tougher immigration controls and repatriation of unemployed immigrants); 2) authoritarianism as an institutional embodiment and realization of the idea of a strong government and state. According to Dutch researcher C. Mudde, authoritarianism in this context must be considered, in particular, as a belief in a rigidly organized society with a strong authority that ensures law and $\operatorname{order}^{18}$ (requirements for guaranteeing a high degree of internal security of the state; strengthening the role of the state in matters of ensuring law and order; the possibility of suspending certain rights and freedoms in order to protect the state from subversive activities); 3) national capitalism and "welfare chauvinism" (counteraction to the domination of foreign financial capital; protectionism, support for the national manufacturer, small and mediumsized businesses by providing tax privileges; guaranteeing a high standard of living, access to social goods and services, employment only for citizens belonging to the indigenous nation); 4) isolationism, antiglobalization or Euroscepticism (negative attitude towards multiculturalism; demands for strengthening and preserving national identity and culture through isolationism and strengthening national homogeneity).

Among the additional indicators of "new right" political parties we can distinguish the following: 1) criticism of traditional right parties for ideological apostasy, transition to positions of liberalism, compromises with ideological opponents, as a result of which they became complicit in creating a new social and cultural reality with its departure from the tradition and morality; 2) criticism of the establishment (antiestablishment position) for "anti-national politics" and "corruption".

18 Mudde C. Populist Radical Right Parties in Europe. Cambridge: Cambridge University Press, 2007. P. 22-23. 
In opposition to the ruling elite and parties they, unlike the "old" right-wing radical forces, do not aim to overthrow the existing political system by operating within it. Effective means of nonviolent change of the modern society have been proposed by the "new right" in the context of rethinking the essence of revolution. It is interesting that for these purposes they referred to their ideological opponents - the left. It is a strategy of "right gramscism" developed by one of the intellectual leaders of the "new right" A. de Benoist based on the mentioned concept of A. Gramsci. Its essence lies in the need to overcome leftist discourse, which dominates in the modern Western political culture, by means of developing a right ideology that is competitive in the new social and cultural circumstances, which intellectuals have yet to put into practice ${ }^{19}$.

\section{Centrist political parties.}

Identifying and analysing the parties of the center, in our opinion, implies the need to adhere to the following methodological principles: first, the understanding of the "center" as a zone of ideological and political rapprochement, touch and interaction of moderate left and right political forces. Second, the conceptualization of "moderation" as: a) a departure from ideological fundamentalism (ideological moderation) manifested in doctrinal synthesis in varying proportions of a number of programmatic provisions of left and right political parties. A striking example of such ideological convergence can be the concepts of liberal socialism (provoking the movement of left parties to the right, respectively, towards the center) and socialist liberalism (causing the displacement of right parties to the left, i.e., also to the center); b) rejection of the violent means of achieving programmatic goals and recognition of the established rules of political play (instrumental moderation). This manifests in respect for the fundamental liberal-democratic principles in general and the methods of political struggle, in particular, the willingness to engage in broad dialogue and to reach a compromise with one's political and ideological opponents.

Third, the conceptualization of ideological moderation as a partially synthesized doctrinal community with left and right is revealed and

19 Тэвдой-Бурмули А. Правый радикализм в Европе. Современная Европа. 2005. № 4. C. 91-92. 
specified in the following provisions: 1) the need for partial state control and regulation of the market, mixed ownership (the possibility of effective coexistence of private and state property, selective nationalization, social market economy, demands of full implementation of the principles of the welfare state, observance of the principle of wide selectivity in providing social goods and services) - "left center"; 2) the need to effectively combine the principles of the free market and the welfare state (the possibility of state intervention in economic life and a broader interpretation of its social functions in order to overcome unemployment and poverty in society, more equitable implementation of the principle of "equality of chances") - "right center" (liberals); 3) the need for state participation in economic processes to ensure a certain standard of living for all citizens, a combination of the principles of moderate conservatism and social liberalism - the "right center" (Christian democratic parties).

It should be noted that the main lines of contact, both between the centrist parties themselves, and between them and the left and right parties, lie in the "traditional" (material) dimension. That is, the ideological communities here are formed around the issues of property, the role of the state in economic life, the principles of economic distribution and the provision of social goods and services. Problems that are not related to this area (for example, "traditional morality", "freedom", "decentralization") are subject to ideological compromises to a lesser extent ${ }^{20}$.

This leads us to believe that the formation of center parties (center-left and center-right) is the result of the conclusion of a broad ideological and political compromise in modern liberal society regarding the basic foundations of its development and, as a consequence, the convergence of exclusively between the traditional (the "old") left parties (mainly in terms of social and economic issues), for which, as noted above, they are criticized, respectively, by the "new left" and "new right". Therefore, we cannot speak of ideological convergence in the "new" (social and cultural) dimension, and, consequently, of the existence of a certain "new center" party, which would be located between the "new left" and "new right".

${ }^{20}$ Keman H. The Search for the Center: Pivot Parties in West European Party Systems. West European Politics. 1994. Vol. 17, Issue 4. P. 138. 
Thus, the reference to the methodological approaches of N. Bobbio and D. Jahn enables us not only to distinguish the main ideological oppositions that underlie the "left-right" party-ideological delineation, but also to clarify the specifics of the definition of left and right political forces, given the particular social and political development of a particular country or region (i.e., to establish additional criteria for identifying left and right in that country or region). Therefore, for the fullfledged scientific application of the "left-right" party-ideological delineation in the context of structuring the political field of the postSoviet countries, including Ukraine, we need to determine the specificity of the aforementioned delimitation in the political systems of the postcommunist states of Central and Eastern Europe.

\section{Specificity of "Left-Right" Party-Ideological Differentiation in the Political Field of Post-Communist States: Peculiarities of the Analysis}

Our initial methodological position is the position of the theory of pluralization about the coexistence in the political landscape of the modern states of traditional (material) and new (post-material) definitions of left and right, which do not displace each other from a political discourse, but only become more or less significant in the context of a certain social, political and economic situation ${ }^{21}$. This approach makes it possible to rethink the traditional view of "left-right" delineation of political sphere in a one-dimensional linear division: the need to consider material and post-material issues in determining the essential characteristics of left and right turns it into two-dimensional. That is, it acquires an orthogonal structure, within which one axis reflects the traditional distinction based on material (economic) issues and the other new, based on post-material (social and cultural) problems. Within the framework of such a two-dimensional structure, there is a "left-right" positioning of political forces: in some conditions, focusing on economic issues, in others - on social and cultural.

The use of a two-dimensional structure of "left-right" partyideological delineation is an indispensable methodological tool in the context of identifying the peculiarities of the appropriate division of

${ }^{21}$ Kitschelt H., Hellemans S. The Left-Right Semantics and the New Politics Cleavage. Comparative Political Studies. 1990. Vol. 23, Issue 2. P. 215-216. 
political forces in the post-communist states of Central and Eastern Europe. Only in this way the whole palette of cognitive possibilities is revealed, firstly, to capture the differences that exist between the positioning of parties in the consolidated democracies of the West and in the post-communist states of the region, which determine different options of the combination of material and post-material issues; secondly, to effectively overcome this conceptual difficulty in identifying left and right in the political sphere of Central and Eastern Europe.

Therefore, according to the theoretical approach of German researcher $\mathrm{H}$. Kitschelt, in modern democracies the main political distinctions that determine inter-party competition revolve around three main questions: Who is the player? What are the rules of collective choice? How should players be endowed with resources? In the political and practical dimension, these issues are specified in the definition, first, by the criteria of citizenship; second, by collective decision-making procedures; third, by the criteria for allocating resources and opportunities among citizens ${ }^{22}$.

Based on this methodological approach, H. Kitschelt substantiated the position that the fundamental basis for differences in the structure of party competition (and, respectively, and in the positioning of parties within the two-dimensional "left-right" division) of developed democracies and post-communist countries embarking on the path of democratization, are their different economic status quo or, in other words, different starting points for resource allocation criteria. The positioning of parties in this material dimension determines the specificity of their answers to the first two of the mentioned questions, which are intangible.

Thus, the structure of party competition and the peculiarities of material and post-material issues are compounded by the fundamental conflict between defenders and opponents of existing property rights and economic distribution models: defenders of the economic status quo, unwilling to threaten it, oppose the processes of democratization and the process of liberalization of citizenship, because, according to $\mathrm{H}$. Kitschelt, in the future, these processes lead to unpredictable changes

${ }^{22}$ Kitschelt H. The Formation of Party Systems in East Central Europe. Politics and Society. 1992. Vol. 20, Issue 1. P. 11-13. 
in the division of resources. Therefore, the defenders of the preservation of existing economic relations will always adhere to traditionalist, nationalist and authoritarian positions, seeking to prevent the political rights of new social groups (including them in the political process) from being granted political rights and limiting the empowerment of citizens in the political decision-making process.

Thus, according to H. Kitschelt's approach, in the West, where the status quo is a market economy, its defenders are "new right" who are at the same time nationalists, traditionalists (paternalists) and supporters of authoritarian principles of governing and the political decision-making. Consistent opponents of the current economic system here are the "new left", who supplement their anti-market position with libertarian demands for the liberalization and democratization of social and political life, advocating, in particular, for the expansion of the sphere of political participation of citizens and the decentralization of political decisionmaking procedures.

Instead, in the post-communist states, where the economic status quo was diametrically opposite at the beginning of the processes of their social, political and economic transformation - the non-market mode of resource allocation (planned economy), the situation with parties regarding material and post-material issues was fundamentally different. Defenders of the status quo here are mostly left-wing political parties that oppose liberal-democratic reforms, appealing to those social groups that have suffered (lost) most as a result of transit to a market economy and a democratic political system. Hence, the aforementioned political forces occupy traditionalist, nationalist and authoritarian positions.

Supporters of the market economy, and therefore the opponents of maintaining the status quo in these countries are the right political parties. They actively advocate for deep liberal-democratic reforms in order to broaden the scope of political participation of citizens and to eliminate the system of economic distribution based on non-market mechanisms. Moreover, these political forces represent the so-called "winners" of transit. However, the exceptions here are the far-right parties. They belonged to the anti-communist opposition, but because of their ideological convictions, they supported traditionalist, nationalist and authoritarian values. Therefore, according to $\mathrm{H}$. Kitschelt, these parties are more likely to resist the liberalization and democratization of political 
life and hinder the transition to a market economy than act as catalysts for these transformations ${ }^{23}$.

A comprehensive approach to the explaining the peculiarities of the party competition structure of the post-communist states of Central and Eastern Europe and identifying in this context the specifics of the left and right parties combining issues of material and post-material nature were suggested by American researcher $M$. Tavits and Polish scientist $\mathrm{N}$. Letki. Their initial methodological setting is a provision according to which the choice of a particular policy by all parties in the region is determined by the following factors: the legacy of the previous regime, and the dual nature of transit - towards democracy and a market economy.

We mean that on the one hand, large-scale economic reforms, accompanied by widespread unemployment, high inflation, low economic growth and, as a consequence, reduced fiscal revenues, have put the need for tight budgetary measures on the agenda, primarily by reducing government spending on social policy. On the other hand, the transformation of a planned economy with a broad social security system into a liberal market economy has led to the formation of large groups of citizens who have lost their jobs, stable income and social support from the state. Thus, they clearly associate the significant decrease in their standard of living and the increase of social and economic inequality in society with the implementation of economic reforms aimed at the rapid transition from the universal welfare state that existed under the previous regime to the free market. Against this background, these groups form a significant public demand for left-wing economic policies related to the rebuilding of the broader social security system in particular and of "socialist justice" as a whole, which existed under the previous regime.

In these circumstances, all parties have to choose between two diametrically opposite types of policy (right and left), the main parameters of which are set by the following strategic alternatives: either the realization of effective economic factors for the implementation of a business with an economic economy (and it uses its political policy), or the satisfaction of the most important economic problems concerning

${ }^{23}$ Kitschelt H. The Formation of Party Systems in East Central Europe. Politics and Society. 1992. Vol. 20, Issue 1. P. 15-41. 
public records for public servants in support ${ }^{24}$. A particular attention should be paid here to the fact that the choice of one or the other party by one of the two alternatives mentioned does not always coincide with the ideological principles fixed in its program.

Thus, in particular, some of the left-wing parties prefer the right economic policy, even though, in the face of social and economic difficulties and the increasing number of "transit failures", the leftwing policy alone is more favourable from an electoral point of view. However, this applies only to those left who seek to effectively integrate into the new political and economic reality of the postcommunist states by a complete break with the communist past. After the fall of authoritarian regimes in Central and Eastern Europe, the left was said to be unpopular in society and not considered by other parties as possible partners, as they were perceived as successors of previously ruling communist parties and carriers of discredited authoritarian communist ideas.

In these circumstances the most successful strategy for adapting to the new reality for those left-wing parties that declared their complete break with communist ideology and the transition to the positions of social democracy, was the rejection of nostalgia for the socialist past, as well as unpardonable appeals, could be interpreted as the desire of these parties to return to the old regime. Therefore, in order to get rid of the rogue status in the political system, to participate effectively in electoral campaigns and gain power, these parties had not only to fix their commitment to democracy and the free market, but also to pursue the right economic policy, including as political forces in charge. Moreover, such a choice by the left-wing parties of the right economic policy does not lead to the loss of their traditional supporters. This is due in particular to the fact that they have a clear socialist image: left-wing voters perceive right-liberal economic reforms carried out by left parties as really necessary, justified and thoroughly considered - why else do parties with a socialist ideology perform a suicidal policy from the point of view of the electorate? In addition, the radical decommunization that has taken

${ }^{24}$ Tavits M., Letki N. When Left is Right: Party Ideology and Policy in PostCommunist Europe. American Political Science Review. 2009. Vol. 103, Issue 4. P. 555556; Tavits M., Letki N. From Values to Interests? The Evolution of Party Competition in New Democracies. The Journal of Politics. 2014. Vol. 76, Issue 1. P. 248-249. 
place in some countries in the region has strongly tied voters with a communist past to the left, especially to former communist parties ${ }^{25}$.

Right-wing parties, on the other hand, do not have as much loyal and stable electorate as left-wing parties (among the main reasons, in particular, greater fragmentation in the Central and Eastern European countries of the right side of the party spectrum than the left, as well as the lack of right-wing and strong party organizations, that leftist have), forced to prevent the loss of votes of those who are frustrated with the reforms, to turn and implement a leftist economic policy: to support under the slogans of protecting the people from the negative effects of economic have formed the need for state intervention in the economy and have increased spending on social programs ${ }^{26}$.

However, these policies of right-wing or center-right parties can cause voter distrust and therefore might not bring them the required electoral result. In this case, these parties are trying to implement another strategy: to shift voters' attention to economic and cultural issues, such as nationalism, traditional morality, anti-multiculturalism, decommunization, minority rights (their interpretation as a threat to majority rights).

In other words, right-wing parties here seek to downplay the importance of economic problems and shift the mainstream of party competition with the left into the post-material dimension, in which they intend to increase their electoral support, intensely appealing to these issues. Also, this strategy allows the right-wing parties, which, economically speaking, prefer the "left" policy, to maintain their own general ideological identity. However, the mentioned strategy will be successful only if there are social divisions on the ethnic and/or religious basis in society that can politicize the right parties $^{27}$.

All this has led researchers to deduce and substantiate the following correlations: first, the increase in social and economic inequality is more likely to reduce the importance of post-material dimension of party competition (reflected in the convergence of party positions in this

${ }^{25}$ Tavits M., Letki N. When Left is Right: Party Ideology and Policy in PostCommunist Europe. American Political Science Review. 2009. Vol. 103, Issue 4. P. 555-558.

${ }^{26}$ Ibid. P. 567.

${ }^{27}$ Tavits M., Letki N. From Values to Interests? The Evolution of Party Competition in New Democracies. The Journal of Politics. 2014. Vol. 76, Issue 1. P. 247-249. 
dimension) in ethnically homogeneous societies rather than in ethnically homogeneous ones; second, increasing social and economic inequality is more likely to reduce the importance of the post-material dimension of party competition in secular than in religious societies; third, the presence in the society with large social and economic inequalities of both ethnic and religious social divisions creates especially favourable opportunities for parties to intensify the post-material dimension of party competition; fourth, in societies with large social and economic inequalities, where there is a strong demand for left-wing economic policy, the left-wing parties will emphasize on the economic dimension of party competition and the right-wing parties otherwise will emphasize on social and cultural dimension ${ }^{28}$.

Therefore, based on the theoretical approaches analysed, we can conclude that the following methodological parameters in the study and determination of the specifics of the "left-right" party-ideological differentiation in the post-communist states of Central and Eastern Europe are as follows:

- peculiarities of positioning the left-wing parties within the framework of the two-dimensional structure of the "left-right" partyideological differentiation, and therefore the specificity of the combination of material and post-material issues is conditioned by their chosen strategies of adaptation to the new social, political and economic conditions resulting from the double transit from the communist authoritarian regime towards democracy and the free market. Therefore, if a political force has chosen the path of ideological and organizational development in the format of the Social Democratic Party, whose leaders position themselves as technocrats and pragmatists, for whom the effective solution of current political and economic problems, rather than ideological issues, is of paramount importance, it will stand on moderately pro-market positions in a material dimension (on the one hand, criticism of the neoliberal model of capitalism, which allows the party to retain its socialist image, and on the other, a commitment to the market mechanisms that must be viable within a mixed economy), and within the post-material - parties will defend the need for liberalization and democratization of political life. In this way, the party is focused both

${ }^{28}$ Tavits M., Letki N. From Values to Interests? The Evolution of Party Competition in New Democracies. The Journal of Politics. 2014. Vol. 76, Issue 1. P. 253-256. 
on maintaining its traditional voters, a large part of them are "transit losers", and in attracting new voter groups, including "transit winners".

If a party positions itself as a political force that is consistently committed to socialist ideals, then in a material dimension it will stand in clear anti-market positions, and in the post-material - it will appeal to traditionalist, nationalist and authoritarian values. In this way, the party, actively using the nostalgia for the "socialist past", aims to obtain maximum support from the "transit losers", who it promises to protect against "predatory" neoliberalism and to restore the "traditional socialist order" in society.

It should be noted that a consistent anti-market, anti-capitalist position is also upheld by the "new left" parties. However, being committed to socialist ideals, they at the same time categorically break with the model of socialism that the Soviet Union sought in the past to lead to the enslavement of man and the establishment of an authoritarianbureaucratic system. Therefore, as far as they can distance themselves from the "socialist past" and uphold the libertarian principles in the postmaterial dimension, they focus primarily on attracting new social groups - post-materialists, as well as a certain part of the "transit losers";

- peculiarities of positioning the right-wing parties within the framework of the two-dimensional structure of the «left-right» partyideological differentiation, and therefore the specificity of the combination of material and post-material issues is conditioned by the degree of effectiveness of those political, social and economic transformations that takes place in post-communist societies. The point is that right-wing, being the main heirs to the anti-communist opposition that existed under the previous regime, were the main initiators of the liberal and democratic transformations in the social, political and economic spheres at the beginning of the transit. However, the further course of these reforms identified different options for combining the right economic and social and cultural issues. Therefore, the right (liberals) in the material dimension are consistent supporters of the free market, in the post-material - libertarian values. Increasing social and economic inequality in society causes them to soften their liberal economic policies, which is manifested in their shift to the left-wing and the transition to positions of left-wing (social) liberalism. By advocating for a socially-oriented market economy and increasing government spending on social programs, they seek to minimize the negative effects 
of economic reform. In this way, they represent the interests of "transit winners" in the first place and focus on attracting some of the "transit losers".

Rights (conservatives) in the material dimension are supporters of the free market, and in the post-material are supporters of the traditionalists, nationalists and authoritarian values. In the face of increasing of social and economic inequality in society, they focus precisely on social and cultural issues, seeking to shift voters' attention from economic problems and maintain their right-wing identity within the framework of a forced appeal to left-wing economic policy. This is especially characterising the extreme right-wing parties, which, in material terms, oppose the neoliberal model of market relations and argue for the need to develop a national-oriented market economy (national capitalism), from the standpoint of protectionism and of such a model of economic redistribution, which will provide benefits to the indigenous peoples (economic nationalism). In this context, they appeal to leftist ideas about the need for government intervention in economic policy and for increasing the cost of social programs. In the post-material dimension, they reject the denial of libertarian values that violates the "traditional order", speaking from the standpoint of nationalism, anti-multiculturalism and traditional (religious) morality. In this way, the aforementioned political forces are oriented towards attracting the voices of both nationalist and / or religious "transit losers" of transit and those "winners" of transit who have clear "new right" ideological attitudes.

\section{CONCLUSIONS}

Thus, the research shows: firstly, how by applying a deductive (a priori) approach, to find out that the fundamental ideological opposition, which determines the essence of the "left-right" partyideological delineation, is to oppose the principles of equality and social hierarchy (inequality).

Secondly, to find out that the differentiation has a dynamic and varied character. That is, it must be taken into account that the meaningful content of the concepts of "left" and "right" is not constant, but varies depending on the characteristics of a particular stage of social evolution and social and political specificity of a particular region or individual state. Therefore, it is necessary to determine the basic and additional characteristics of the left and right. The main ones are stable 
and valid at all times and contexts, allowing for a clear "left-right" distinction of political forces, while additional ones are subject to change depending on time and context, which helps to capture the features of the "left-right" dichotomy in different periods and its national specificity.

Thirdly, to determine that at the present stage of social and political evolution, in the conditions of transition from advanced industrial states to the post-industrial stage of development, there is a change in the traditional concept of "left-right" delimitation in the format of onedimensional linear division. We are talking about its complication. That is, based on the principles of the theory of pluralism, we substantiated the need to consider in determining the essential features of left and right as traditional (material) and new (post-material) issues. In these circumstances, this separation acquires a two-dimensional, orthogonal structure, within which one axis reflects the traditional distinction based on material (economic) issues and the other - new one based on postmaterial (social and cultural) problems.

Fourthly, to find out the specifics of the "left-right" party-ideological division in the political systems of the post-communist countries of Central and Eastern Europe. It is caused by the peculiarities of the double transit of the states of the mentioned region - from authoritarianism to democracy; from planned to market economy. This determines the differences that are based on diametrically opposite variants of the combination of material and post-material issues by parties in the structures of party competition of post-state states and countries with a consolidated democratic regime.

Fifthly, drawing on the aforementioned methodological frameworks, to create indicators lists that can be used to identify the affiliation of a particular political force to the left (or "new left"), right (or "new right") or centrist (center-left or center-right) parties.

\section{SUMMARY}

The article, based on a deductive (a priori) approach, found that the fundamental ideological opposition, which determines the essence of the "left-right" distinction, is the juxtaposition of the principles of equality and social hierarchy (inequality). This demarcation has been found to have a dynamic, variable nature. Indicators have been determined that will allow the identification of a particular political force for the left (or "new left"), right (or "new right") or centrist (center-left / center-right) 
parties. The specificity of the "left-right" party-ideological delineation, which has developed in the political space of the post-communist states of Central and Eastern Europe, has been determined. It is proved that the peculiarities of positioning of the left parties within the framework of the two-dimensional structure of the "left-right" party-ideological division, and, consequently, the peculiarity of the combination of material and post-material issues are due to their chosen strategies of adapting to the new political and economic conditions that resulted from the double transit of the states of the mentioned region - from authoritarianism to democracy; from planned to market economy. It is substantiated that the peculiarities of positioning the right parties within the framework of the two-dimensional structure of the "left-right" party-ideological division, and therefore the specificity of the combination of material and postmaterial issues, are conditioned by the degree of effectiveness of those political and social and economic transformations that occur in postcommunist societies.

\section{REFERENCES}

1. Грамши А. Тюремные тетради: в 3-х ч. Ч. 1. / пер. с итал. Москва: Политиздат, 1991. 560 с.

2. Инглхарт Р. Постмодерн: меняющиеся ценности и изменяющиеся общества. Полис. 1997. № 4. С. 6-32.

3. Маркузе Г. Одномерный человек / пер. с англ. А. Юдина. Москва: REFL-book, 1994. XXII, 368 с.

4. Тэвдой-Бурмули А. Правый радикализм в Европе. Современная Европа. 2005. № 4. С. 86-98.

5. Bobbio N. Left and Right: The Significance of a Political Distinction / translated and introduced by A. Cameron. Chicago: The University of Chicago Press, 1997. XXII, $124 \mathrm{p}$.

6. De Vries C. E., Hakhverdian A., Lancee B. The Dynamics of Voters' Left/Right Identification: The Role of Economic and Cultural Attitudes. Political Science Research and Methods. 2013. Vol. 1, Issue 2. P. 223-238.

7. Downs A. An Economic Theory of Political Action in a Democracy. The Journal of Political Economy. 1957. Vol. 65, Issue 2. P. 135-150. 
8. Huber J., Inglehart R. Expert Interpretations of Party Space and Party Locations in 42 Societies. Party Politics. 1995. Vol. 1, Issue 1. P. 73-111.

9. Inglehart R., Flanagan S. C. Value Change in Industrial Societies. The American Political Science Review. 1987. Vol. 81, Issue 4. P. 1289-1319.

10. Inglehart R., Klingemann H.-D. Party Identification, Ideological Preference and the Left-Right Dimension among Western Mass Publics. Party Identification and Beyond: Representations of Voting and Party Competition / I. Budge, I. Crewe, D. J. Farlie (eds.). Colchester: ECPR Press, 2010. P. 243-274.

11. Jahn D. Conceptualizing Left and Right in Comparative Politics: Towards a Deductive Approach. Party Politics. 2011. Vol. 17, Issue 6. P. 745-765.

12. Jahn D. What is Left and Right in Comparative Politics? A Response to Simon Franzmann. Party Politics. 2014. Vol. 20, Issue 2. P. 297-301.

13. Keman H. The Search for the Center: Pivot Parties in West European Party Systems. West European Politics. 1994. Vol. 17, Issue 4. P. 124-148.

14. Kitschelt H. The Formation of Party Systems in East Central Europe. Politics and Society. 1992. Vol. 20, Issue 1. P. 7-50.

15. Kitschelt H., Hellemans S. The Left-Right Semantics and the New Politics Cleavage. Comparative Political Studies. 1990. Vol. 23, Issue 2. P. 210-238.

16. Knutsen O. Value Orientations, Political Conflicts and Left-Right Identification: A Comparative Study. European Journal of Political Research. 1995. Vol. 28, Issue 1. P.63-93.

17. Mudde C. Populist Radical Right Parties in Europe. Cambridge: Cambridge University Press, 2007. 385 p.

18. Rosas J. C., Ferreira A. R. Left and Right: Critical Junctures. Left and Right: The Great Dichotomy Revisited / J. C. Rosas, A. R. Ferreira (eds.). Newcastle upon Tyne: Cambridge Scholars Publishing, 2013. P. 2-20.

19. Tavits M., Letki N. From Values to Interests? The Evolution of Party Competition in New Democracies. The Journal of Politics. 2014. Vol. 76, Issue 1. P. 246-258. 
20. Tavits M., Letki N. When Left is Right: Party Ideology and Policy in Post-Communist Europe. American Political Science Review. 2009. Vol. 103, Issue 4. P.555-569.

21. Weber W. Behind Left and Right. The Meaning of Left-Right Orientation in Europe. URL: http://www.tdx.cat/bitstream/handle/ 10803/107624/tww.pdf?sequence=1. 153 p. （дата звернення: 21.09.2019).

\section{Information about the author: Shypunov H. V.}

Doctor of Political Sciences, Associate Professor, Department of Theory and History of Political Science, Ivan Franko Lviv National University 1, Universytetska str., Lviv, 79000, Ukraine

Prokop M.

$\mathrm{PhD}$ (Candidate of Political Sciences), Adjunct, Institute of International Relations and Public Policies, Faculty of Law and Social Sciences, Jan Kochanowski University in Kielce, Kielce, Poland 


\section{NOTES}




\section{NOTES}



Publishing house "Liha-Pres"

9 Kastelivka str., Lviv, 79012, Ukraine 44 Lubicka str., Torun, 87-100, Poland

Printed by the publishing house "Liha-Pres"

Passed for printing: August 28, 2019.

A run of 150 copies. 